\title{
AS CÉLULAS DE DERIVA LITORÂNEA E A EROSÃO NAS PRAIAS DO ESTADO DE SĀO PAULO
}

Celia Regina de Gouveia Souza

Orientador: Prof. Dr. Kenitiro Suguio

TESE DE DOUTORAMENTO

Programa de Pós-Graduação em Geologia Sedimentar

(VOLUME I - TEXTO) 


\section{AS CÉLULAS DE DERIVA LITORÂNEA E A EROSÃO NAS PRAIAS DO ESTADO DE SÃO PAULO}

CELIA REGINA DE GOUVEIA SOUZA

Orientador: Prof. Dr. Kenitiro Suguio

TESE DE DOUTORAMENTO

COMISSÃO JULGADORA

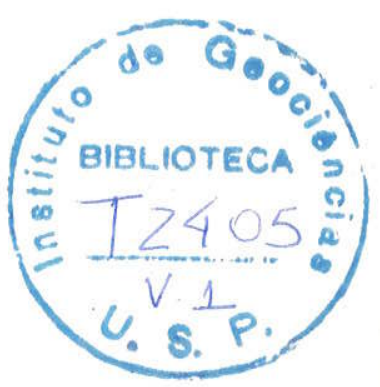

Nome

Presidente: Prof. Dr. Kenitiro Suguio

Examinadores: Prof. Dr. Armando Márcio Coimbra

Prof. Dr. Paolo Alfredini

Prof. Dr. Paulo César Fonseca Giannini

Prof. Dr. Rodolfo José Angulo

SÃO PAULO

1 : 997
Assinatura

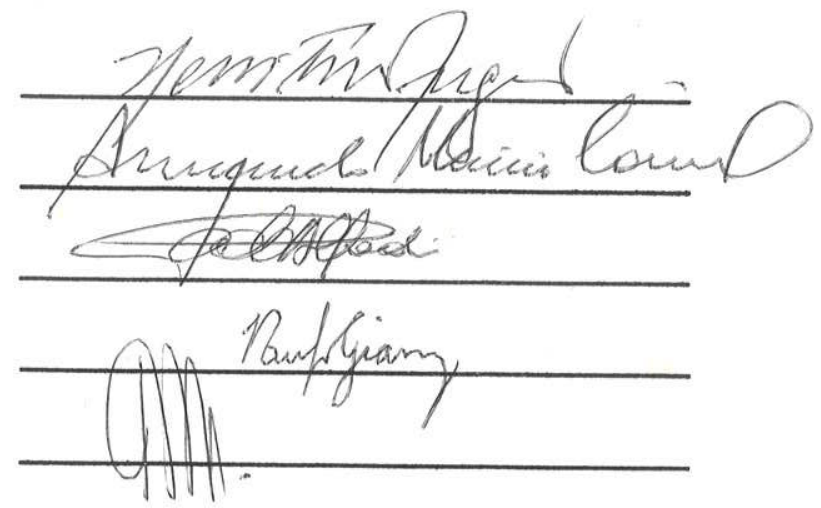




\section{UNIVERSIDADE DE SÃO PAULO \\ INSTITUTO DE GEOCIENCIAS}

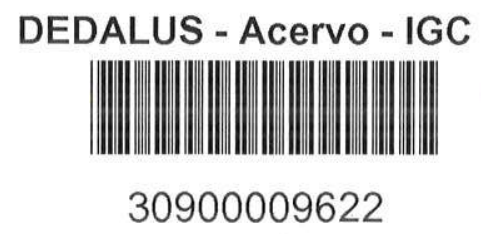

\section{AS CÉLULAS DE DERIVA LITORÂNEA E A EROSÃO NAS PRAIAS DO ESTADO DE SÃO PAULO}

Celia Regina de Gouveia Souza

Orientador: Prof. Dr. Kenitiro Suguio

TESE DE DOUTORAMENTO

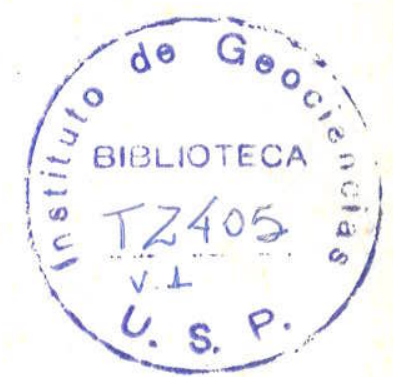

Programa de Pós-Graduação em Geologia Sedimentar

(VOLUME I - TEXTO) 
Dedico este trabalho...

Ao Agenor e à Flora: meus maiores e mais valiosos tesouros...

Ao Gomendador Goweia (in memorian) e à "matriarca" Gonceisãa: pela fibra e pelas oportunidades de chegar onde chequei... e pelo orgutho de tê-los como pais. 
Uma homenagem especial...

Da infancia ficaram as longas e divertidas brincadeiras $e$ os "rotinhos nos cabelos". Na fase adulta uma ineoplicável distancia... No fim, o respeito e o reconhecimento pela grande lisão de coragem e dignidade. Aquele que partiu em meus brasos e de quem owi a ültima palaura (assim como foi com nosso pai):

Sérgio, mew irmão... Sonhe em paz! 


\section{APRESENTAÇÃO}

AGRADECIMENTOS

RESUMO

xiv

ABSTRACT

$x V$

\section{SUMÁRIO}

\section{VOLUME I}

I. INTRODUÇÃO

II. OBJETIVOS 3

III. A AREA DE ESTUDO 4

III.1.Contextos Geológico, Geomorfológico, Climatico e Oceanografico REGIONAIS

III.1.1. Geologia

III.1.2. Geomorfologia

III.1.3. Clima

III.1.4. Oceanografia

III.2. Sintese de Outros LeVantamentos sobre a Área de Estudo

IV. ABORDAGEM METODOLÓGICA

IV.1. A PRAIA

IV.1.1. Definições

IV.1.2. Os Processos Costeiros

IV.1.3. O Balanço Sedimentar nas Praias

IV.1.4. A Classificação de Praias

IV.2. MÉtodos de TRABalho

IV.2.1. Análise de Documentos Cartográficos e de Sensoriamento Remoto

IV.2.2. Trabalhos de Campo

IV.2.3. Trabalhos de Laboratório

IV.2.4. Tratamento de Dados

IV.2.5. Apresentação de Dados e Resultados

V. CARACTERIZAÇÃO MORFODINÂMICA DA COSTA PAULISTA 37

V.1. SETOR MORFODINÂMICO I 
V.2. SETOR MORFODINÅMICO II

V.3 SETOR MORFODINÁMICO III

V.4. SETOR MORFODINÂMICO IV

V.5. SETOR MORFODINÂMICO V

V.6. SETOR MORFODINÁMICO VI

V.7. SETOR MORFODINÁMICO VII

VI. AS CÉLULAS DE DERIVA LITORÂNEA NAS PRAIAS PAULISTAS E O TRANSPORTE COSTEIRO

VI.1. SETOR MORFODINÁMICOI

VI.1.1. Análise de Produtos de Sensoriamento Remoto

VI.1.2. Método de TAGGART \& SCHWARTZ-modificado

VI.1.3. Mètodo de McLAREN

VI.1.4. Conclusões

VI.2. SETOR MORFODINÂMICO II

VI.2.1. Análise de Produtos de Sensoriamento Remoto

VI.2.2. Método de TAGGART \& SCHWARTZ-modificado

VI.2.3. Método de McLAREN

VI.2.4. Conclusões

VI.3. SETOR MORFODINÂMICO III

VI.3.1. Análise de Produtos de Sensoriamento Remoto

VI.3.2. Método de TAGGART \& SCHWARTZ-modificado

VI.3.3. Método de MCLAREN

VI.3.4. Conclusões

VI.4. SETOR MORFODINÅMICO IV

VI.4.1. Análise de Produtos de Sensoriamento Remoto

VI.4.2. Método de TAGGART \& SCHWARTZ-modificado

VI.4.3. Método de McLAREN

VI.4.4. Conclusões

VI.5. SETOR MORFODINÂMICO V

VI.5.1. Análise de Produtos de Sensoriamento Remoto

VI.5.2. Método de TAGGART \& SCHWARTZ-modificado 
VI.6. SETOR MORFODINÂMICO VI

VI.6.1. Análise de Produtos de Sensoriamento Remoto $\quad 123$

VI.6.2. Método de TAGGART \& SCHWARTZ-modificado 124

VI.6.3. Método de McLAREN 125

VI.6.4. Conclusões $\quad 126$

VI.7. SETOR MORFODINÁMICO VII

VI.7.1. Análise de Produtos de Sensoriamento Remoto 127

VI.7.2. Método de TAGGART \& SCHWARTZ-modificado 127

$\begin{array}{ll}\text { VI.7.3. Método de McLAREN } & 148\end{array}$

$\begin{array}{ll}\text { VI.7.4. Conclusões } & 148\end{array}$

VII. A EROSÃO COSTEIRA NO ESTADO DE SÃO PAULO 152

VII.1. A EROSÃo COSTEIRA NOS SETORES MORFODINÂMICOS 157

$\begin{array}{ll}\text { VII.1.1. Setor Morfodinâmico I } & 157\end{array}$

VII.1.2. Setor Morfodinâmico II 159

VII.1.3. Setor Morfodinâmico III

VII.1.4. Setor Morfodinâmico IV 163

VII.1.5. Setor Morfodinâmico V 165

VII.1.6. Setor Morfodinâmico VI 165

VII.1.7. Setor Morfodinâmico VII 166

VII.2. AVAliação da Regra de BruUn através da Comparação de Cartas BATIMÉTRICAS DO LITORAL PAULISTA 169

VIII. CONSIDERAÇÕES FINAIS 172

$\begin{array}{ll}\text { IX. REFERENCIAS BIBLIOGRÁFICAS } & 179\end{array}$

\section{VOLUME II}

Anexos Gerais

Anexos Referentes ao Setor Morfodinâmico 1

Anexos Referentes ao Setor Morfodinâmico II

Anexos Referentes ao Setor Morfodinâmico III

Anexos Referentes ao Setor Morfodinâmico IV

Anexos Referentes ao Setor Morfodinâmico $\mathrm{V}$

Anexos Referentes ao Setor Morfodinâmico VI 


\section{LISTA DE FIGURAS, TABELAS, QUADROS E FOTOS DE CAMPO}

\section{FIGURAS (Volume II)}

Figura 1: Localização da área de estudo

Figura 2: Compartimentação morfodinâmica do litoral paulista

Figura 3: Montagem do trecho litorâneo da carta geotécnica do Estado de São

Paulo mostrando a circulação costeira segundo PONÇANO et al. (1994)...

Figura 4: Rumos de transporte costeiro obtidos a partir de sensoriamento remoto (setor morfodinâmico I)

Figura 5: Células de deriva litorânea obtidas a partir do método de TAGGART \& SCHWARTZ-modificado (setor morfodinâmico I)

Figura 6: Variação da largura nas praias do setor morfodinâmico 1

Figura 7: Variação da inclinação nas praias do setor morfodinâmico 1

Figura 8: Variação dos parâmetros texturais na Praia de lliha Comprida

Figura 9: Variação dos parâmetros texturais na Praia do Leste

Figura 10: Variação dos parâmetros texturais na Praia da Juréia

Figura 11: Rumos de transporte costeiro obtidos a partir de sensoriamento remoto (setor morfodinâmico II)

Figura 12: Células de deriva litorânea obtidas a partir do método de TAGGART \& SCHWARTZ-modificado (setor morfodinâmico II)

Figura 13: Variação da largura nas praias do setor morfodinâmico II

Figura 14: Variação da inclinação nas praias do setor morfodinâmico II

Figura 15: Variação dos parâmetros texturais nas praias do Rio Verde e Itacolomi

Figura 16: Variação dos parâmetros texturais na Praia do Una

Figura 17: Variação dos parâmetros texturais na Praia do Guaraú

Figura 18: Rumos de transporte costeiro obtidos a partir de sensoriamento remoto (setor morfodinâmico III)

Figura 19: Células de deriva litorânea obtidas a partir do método de TAGGART \& SCHWARTZ-modificado (setor morfodinâmico III)

Figura 20: Variação da largura nas praias do setor morfodinâmico III

Figura 21: Variação da inclinação nas praias do setor morfodinâmico III

Figura 22: Variação dos parâmetros texturais na Praia Peruíbe

Figura 23: Variação dos parâmetros texturais na Praia de Itanhaém

Figura 24: Variação dos parâmetros texturais na Praia Grande

Figura 25: Rumos de transporte costeiro obtidos a partir de sensoriamento remoto (setor morfodinâmico IV)

Figura 26: Células de deriva litorânea obtidas a partir do método de TAGGART \& SCHWARTZ-modificado (setor morfodinâmico IV)

Figura 27a: Variação da largura nas praias do setor morfodinâmico IV

Figura 27b: Variação da largura nas praias do setor morfodinâmico IV

Figura 28a: Variação da inclinação nas praias do setor morfodinâmico IV

Figura 28b: Variação da inclinação nas praias do setor morfodinâmico IV

Figura 29: Variação dos parâmetros texturais nas praias de São Vicente, Itararé e Santos

Figura 30: Variação dos parâmetros texturais na Praia do Guaiúba

Figura 31: Variação dos parâmetros texturais na Praia do Tombo

Figura 32: Variação dos parâmetros texturais nas praias de Astúrias e 
Figura 33: Variação dos parâmetros texturais na Praia da Enseada

Figura 34: Variação dos parâmetros texturais nas praias de Pernambuco e Mar Casado

Figura 35: Variação dos parâmetros texturais na Praia do Perequê

Figura 36: Variação dos parâmetros texturais nas praias de São Pedro e Iporanga

Figura 37: Rumos de transporte costeiro obtidos a partir de sensoriamento remoto (setor morfodinâmico $\mathrm{V}$ )

Figura 38: Células de deriva litorânea obtidas a partir do método de TAGGART \& SCHWARTZ-modificado (setor morfodinâmico V)

Figura 39a: Variação da largura nas praias do setor morfodinâmico $V$

Figura 39b: Variação da largura nas praias do setor morfodinâmico $V$

Figura 40a: Variação da inclinação nas praias do setor morfodinâmico $\mathrm{V}$

Figura 40b: Variação da inclinação nas praias do setor morfodinâmico $V$

Figura 40c: Variação da inclinação nas praias do setor morfodinâmico $\mathrm{V}$

Figura 41: Variação dos parâmetros texturais na Praia de Bertioga

Figura 42: Variação dos parâmetros texturais na Praia de São Lourenço

Figura 43a: Variação dos parâmetros texturais na Praia de Itaguaré

Figura 43b: Variação dos parâmetros texturais na Praia de Guaratuba

Figura 44: Variação dos parâmetros texturais na Praia de Boracéia

Figura 45: Variação dos parâmetros texturais na Praia de Juquehy

Figura 46: Variação dos parâmetros texturais na Praia da Baleia

Figura 47: Variação dos parâmetros texturais na Praia de Boiçucanga

Figura 48: Variação dos parâmetros texturais na Praia de Maresias

Figura 49: Variação dos parâmetros texturais nas praias de Santiago e ToqueToque Pequeno

Figura 50: Variação dos parâmetros texturais na Praia de Guaecá

Figura 51: Variação dos parâmetros texturais na Praia de Barequeçaba

Figura 52: Rumos de transporte costeiro obtidos a partir de sensoriamento remoto (setor morfodinâmico $\mathrm{VI}$ )

Figura 53: Células de deriva litorânea obtidas a partir do método de TAGGART \& SCHWARTZ-modificado (setor morfodinâmico VI)

Figura 54: Variação da largura nas praias do setor morfodinâmico VI

Figura 55: Variação da inclinação nas praias do setor morfodinâmico VI

Figura 56: Variação dos parâmetros texturais nas praias do Balneário, São Francisco e Cigarras

Figura 57: Rumos de transporte costeiro obtidos a partir de sensoriamento remoto (setor morfodinâmico VII)

Figura 58: Células de deriva litorânea obtidas a partir do método de TAGGART \& SCHWARTZ-modificado (setor morfodinâmico VII)

Figura 59a: Variação da largura nas praias do setor morfodinâmico VII

Figura 59b: Variação da largura nas praias do setor morfodinâmico VII

Figura 60a: Variação da inclinação nas praias do setor morfodinâmico VII

Figura 60b: Variação da inclinação nas praias do setor morfodinâmico VII

Figura 60c: Variação da inclinação nas praias do setor morfodinâmico VII

Figura 61: Variação dos parâmetros texturais nas praias de Caraguatatuba, Martim de Sá, Massaguaçu, Mocoóca e Tabatinga

Figura 62: Localização dos perfis praiais e características morfológicas das praias de Caraguatatuba, Martim de Sá e Massaguaçu (SOUZA, 1990) 
Figura 63: Parâmetros texturais das praias de Caraguatatuba, Martim de Sá e Massaguaçu segundo SOUZA (1990)

Figura 64: Variação dos parâmetros texturais nas praias de Maranduba, Sapê e Lagoinha

Figura 65: Variação dos parâmetros texturais nas praias de Fortaleza, Vermelha de Fortaleza, Dura e Lázaro

Figura 66: Variação dos parâmetros texturais nas praias da Enseada, Toninhas e Grande

Figura 67: Variação dos parâmetros texturais nas praias de Itaguá, Iperoig, Perequê-Açu e Barra Seca

Figura 68: Variação dos parâmetros texturais na Praia Vermelha do Norte

Figura 69: Variação dos parâmetros texturais na Praia de Itamambuca

Figura 70: Variação dos parâmetros texturais nas praias do Félix e Prumirim

Figura 71: Variação dos parâmetros texturais na Praia do Puruba

Figura 72: Variação dos parâmetros texturais na Praia de Ubatumirim

Figura 73: Variação dos parâmetros texturais na Praia da Fazenda

Figura 74: Trechos onde foram observadas evidências erosivas no setor morfodinâmico 1

Figura 75: Trechos onde foram observadas evidências erosivas no setor morfodinâmico $\|$

Figura 76: Trechos onde foram observadas evidências erosivas no setor morfodinâmico III

Figura 77: Trechos onde foram observadas evidências erosivas no setor morfodinâmico IV

Figura 78: Trechos onde foram observadas evidências erosivas no setor morfodinâmico $\mathrm{V}$

Figura 79: Trechos onde foram observadas evidências erosivas no setor morfodinâmico $\mathrm{Vl}$

Figura 80a: Trechos onde foram observadas evidências erosivas no setor morfodinâmico VII

Figura 80b: Trechos onde foram observadas evidências erosivas no setor morfodinâmico VII

Figura 81: Localização dos perfis batimétricos traçados nas cartas náuticas no setor morfodinâmico 1

Figura 82: Localização dos perfis batimétricos traçados nas cartas náuticas no setor morfodinâmico II

Figura 83: Localização dos perfis batimétricos traçados nas cartas náuticas no setor morfodinâmico III

Figura 84: Localização dos perfis batimétricos traçados nas cartas náuticas no setor morfodinâmico IV

Figura 85: Localização dos perfis batimétricos traçados nas cartas náuticas no setor morfodinâmico $\mathrm{V}$

Figura 86: Localização dos perfis batimétricos traçados nas cartas náuticas no setor morfodinâmico VII

Figura 87: Comparação entre os perfis batimétricos traçados nas cartas náuticas antigas e recentes no setor morfodinâmico I

Figura 88: Comparação entre os perfis batimétricos traçados nas cartas náuticas antigas e recentes no setor morfodinâmico $\|$

Figura 89: Comparação entre os perfis batimétricos traçados nas cartas náuticas antigas e recentes no setor morfodinâmico III 
Figura 90: Comparação entre os perfis batimétricos traçados nas cartas náuticas antigas e recentes no setor morfodinâmico IV

Figura 91: Comparação entre os perfis batimétricos traçados nas cartas náuticas antigas e recentes no setor morfodinâmico $\mathrm{V}$

Figura 92: Comparação entre os perfis batimétricos traçados nas cartas náuticas antigas e recentes no setor morfodinâmico VII

Figura 93: Variação dos parâmetros texturais nos setores morfodinâmicos

\section{TABELAS (Volume II)}

Tabela 1: Relação dos perfis praiais, comprimento e orientação das praias e condições de campo

Tabela 2: Medidas de ondas efetuadas em fotografias aéreas e interpretações sobre o sentido da deriva litorânea (setor morfodinâmico I)

Tabela 3: Direção de propagação e ângulo de incidência das ondas e rumo da corrente longitudinal (setor morfodinâmico I)

Tabela 4: Medidas de ondas efetuadas em fotografias aéreas e interpretações sobre o sentido da deriva litorânea (setor morfodinâmico II)

Tabela 5: Direção de propagação e ângulo de incidência das ondas e rumo da corrente longitudinal (setor morfodinâmico II)

Tabela 6: Medidas de ondas efetuadas em fotografias aéreas e interpretações sobre o sentido da deriva litorânea (setor morfodinâmico III)

Tabela 7: Direção de propagação e ângulo de incidência das ondas e rumo da corrente longitudinal (setor morfodinâmico III)

Tabela 8: Medidas de ondas efetuadas em fotografias aéreas e interpretações sobre o sentido da deriva litorânea (setor morfodinâmico IV)

Tabela 9: Direção de propagação e ângulo de incidência das ondas e rumo da corrente longitudinal (setor morfodinâmico IV)

Tabela 10: Medidas de ondas efetuadas em fotografias aéreas e interpretações sobre o sentido da deriva litorânea (setor morfodinâmico $\mathrm{V}$ )

Tabela 11: Direção de propagação e ângulo de incidência das ondas e rumo da corrente longitudinal (setor morfodinâmico $\mathrm{V}$ )

Tabela 12: Direção de propagação e ângulo de incidência das ondas e rumo da corrente longitudinal (setor morfodinâmico VI)

Tabela 13: Medidas de ondas efetuadas em fotografias aéreas e interpretações sobre o sentido da deriva litorânea (setor morfodinâmico VII)

Tabela 14: Direção de propagação e ângulo de incidência das ondas e rumo da corrente longitudinal (setor morfodinâmico VII)

Tabela 15: Evidências erosivas observadas no campo e através do método de

TAGGART \& SCHWARTZ-modificado (setor morfodinâmico I)

Tabela 16: Evidências erosivas observadas no campo e através do método de TAGGART \& SCHWARTZ-modificado (setor morfodinâmico II)

Tabela 17: Evidências erosivas observadas no campo e através do método de TAGGART \& SCHWARTZ-modificado (setor morfodinâmico III)

Tabela 18: Evidências erosivas observadas no campo e através do método de TAGGART \& SCHWARTZ-modificado (setor morfodinâmico IV)

Tabela 19: Evidências erosivas observadas no campo e através do método de

TAGGART \& SCHWARTZ-modificado (setor morfodinâmico V) 
Tabela 20: Evidências erosivas observadas no campo e através do método de TAGGART \& SCHWARTZ-modificado (setor morfodinâmico VI)

Tabela 21: Evidências erosivas observadas no campo e através do método de

TAGGART \& SCHWARTZ-modificado (setor morfodinâmico VII)

\section{QUADROS}

\section{Volume I}

Quadro 1: Balanço sedimentar de uma praia

Quadro 2: Principais características dos domínios morfodinâmicos praiais

Quadro 3: Relação das fotografias aéreas utilizadas na pesquisa

Quadro 4: Teste de comparação entre a curtose e o nível de energia nas praias

Quadro 5: Matriz de comparação elaborada para a Praia de llha Comprida

Quadro 6: Matriz de comparação elaborada para a Praia do Leste

Quadro 7: Matriz de comparação elaborada para a Praia da Juréia

Quadro 10: Comparação entre os resultados percentuais dos rumos de transporte obtidos a partir de diferentes métodos utilizados (Setor Morfodinâmico I)

Quadro 11: Matriz de comparação elaborada para as praias do Rio Verde e Itacolomi

Quadro 12: Matriz de comparação elaborada para a Praia do Una

Quadro 13: Matriz de comparação elaborada para a Praia do Guaraú

Quadro 16: Comparação entre os resultados percentuais dos rumos de transporte obtidos a partir de diferentes métodos utilizados (Setor Morfodinâmico II)

Quadro 17: Matriz de comparação elaborada para a Praia de Peruibe

Quadro 18: Matriz de comparação elaborada para a Praia de Itanhaém

Quadro 19: Matriz de comparação elaborada para a Praia Grande

Quadro 22: Comparação entre os resultados percentuais dos rumos de transporte obtidos a partir de diferentes métodos utilizados (Setor Morfodinâmico III)

Quadro 23: Matriz de comparação elaborada para as praias de São Vicente, Itararé e Santos

Quadro 24: Matriz de comparação elaborada para a Praia do Guaiúba

Quadro 25: Matriz de comparação elaborada para a Praia do Tombo

Quadro 26: Matriz de comparação elaborada para a Praia das Astúrias e

Pitangueiras

Quadro 27: Matriz de comparação elaborada para a Praia da Enseada

Quadro 28: Matriz de comparação elaborada para as praias de Pernambuco e Mar Casado

Quadro 29: Matriz de comparação elaborada para a Praia do Perequê

Quadro 30: Matriz de comparação elaborada para as praias de São Pedro e Iporanga

Quadro 33: Comparação entre os resultados percentuais dos rumos de transporte obtidos a partir de diferentes métodos utilizados (Setor Morfodinâmico IV)

Quadro 34: Matriz de comparação elaborada para a Praia de Bertioga

Quadro 35: Matriz de comparação elaborada para a Praia de São Lourenço

Quadro 36: Matriz de comparação elaborada para as praias de ltaguaré e Guaratuba

Quadro 37: Matriz de comparação elaborada para a Praia de Boracéia 
Quadro 40: Matriz de comparação elaborada para a Praia de Boiçucanga

Quadro 41: Matriz de comparação elaborada para a Praia de Maresias

Quadro 42: Matriz de comparação elaborada para as praias de Santiago e Toque-

Toque Pequeno

Quadro 43: Matriz de comparação elaborada para a Praia de Guaecá

Quadro 44: Matriz de comparação elaborada para a Praia de Barequeçaba

Quadro 47: Comparação entre os resultados percentuais dos rumos de transporte obtidos a partir de diferentes métodos utilizados (Setor Morfodinâmico V)

Quadro 48: Matriz de comparação elaborada para as praias do Balneário, São Francisco e Cigarras

Quadro 49-A: Matriz de comparação elaborada para as praias de Caraguatatuba, Martim de Sá, Massaguaçu, Mocoóca e Tabatinga

Quadro 49-B: Matriz de comparação elaborada para as praias de Caraguatatuba, Martim de Sá e Massaguaçu com dados extraídos de SOUZA (1990)

Quadro 50: Matriz de comparação elaborada para as praias de Maranduba, Sapê e Lagoinha

Quadro 51: Matriz de comparação elaborada para as praias de Fortaleza, Vermelha de Fortaleza, Dura e Lázaro

Quadro 52: Matriz de comparação elaborada para as praias de Toninhas e Grande

Quadro 53-A: Matriz de comparação elaborada para as praias de Itaguá e Iperoig

Quadro 53-B: Matriz de comparação elaborada para as praias de Perequê-Açu e Barra Seca

Quadro 54: Matriz de comparação elaborada para a Praia Vermelha do Norte

Quadro 55: Matriz de comparação elaborada para a Praia de Itamambuca

Quadro 56: Matriz de comparação elaborada para as praias do Félix e Prumirim

Quadro 57: Matriz de comparação elaborada para a Praia do Puruba

Quadro 58: Matriz de comparação elaborada para a Praia de Ubatumirim

Quadro 59: Matriz de comparação elaborada para a Praia da Fazenda

Quadro 62: Comparação entre os resultados percentuais dos rumos de transporte obtidos a partir de diferentes métodos utilizados (Setor Morfodinâmico VII)

\section{Volume II}

Quadro 8: Matriz de correlação segundo o método de McLAREN (inverno - setor morfodinâmico I)

Quadro 9: Matriz de correlação segundo o método de McLAREN (verão - setor morfodinâmico l)

Quadro 14: Matriz de correlação segundo o método de McLAREN (inverno - setor morfodinâmico II)

Quadro 15: Matriz de correlação segundo o método de MCLAREN (verão - setor morfodinâmico II)

Quadro 20: Matriz de correlação segundo o método de MCLAREN (inverno - setor morfodinâmico III)

Quadro 21: Matriz de correlação segundo o método de McLAREN (verão - setor morfodinâmico (II)

Quadro 31: Matriz de correlação segundo o método de McLAREN (inverno - setor morfodinâmico IV)

Quadro 32: Matriz de correlação segundo o método de McLAREN (verão - setor morfodinâmico (V) 
Quadro 45: Matriz de correlação segundo o método de MCLAREN (inverno - setor morfodinâmico $\mathrm{V}$ )

Quadro 46: Matriz de correlação segundo o método de McLAREN (verão - setor morfodinâmico $\mathrm{V}$ )

Quadro 60: Matriz de correlação segundo o método de MCLAREN (inverno - setor morfodinâmico VII)

Quadro 61: Matriz de correlação segundo o método de McLAREN (verão - setor morfodinâmico VII)

\section{FOTOS DE CAMPO (Volume II)}

Foto 1: Dunas frontais inativas sobrepostas a terraços marinhos holocênicos na Ilha Comprida (próximo ao ponto 529)

Foto 2: Morfologia característica de toda a porção central da liha Comprida (entre os pontos 529 e 532B), com desenvolvimento de falésias em terraços e dunas holocênicos

Foto 3: Falésia sobre terraços marinhos holocênicos na Praia do Una-Sul

Foto 4: Perfil com características reflexivas na porção centro-sul da Praia do UnaSul

Foto 5: Praia do Guaraú (porção central-norte) - características dissipativas de baixa energia e intensa erosão

Foto 6: Falésias em restos de terraços marinhos e dunas holocênicas na Praia de Peruíbe (porção central)

Foto 7: Urbanização ao sul da Praia de Itanhaém e intensa erosão

Foto 8a: Setor oeste da Praia de Santos, entre o Canal 1 e o espigão do emissário de Santos-São Vicente

Foto 8b: Face direita do espigão do emissário de Santos-São Vicente (Praia de Santos)

Foto 8c: Obras de urbanização na Praia de Itararé sobre deósitos eólicos da póspraia

Foto 9: Praia da Enseada - características intermediárias-dissipativas

Foto 10: Praia do Tombo - características intermediárias a reflexivas

Foto 11: Praia da Bertioga (entre os perfis 109/335 e 100/334) - características dissipativas de alta energia

Foto 12: Praia de Maresias - características intermediárias

Foto 13: Perfil reflexivo no extremo sul da Praia de Boiçucanga

Foto 14: Praia de Barequeçaba - características dissipativas de baixa energia

Foto 15: Porção norte da Praia de São Francisco (continente) - características dissipativas de baixa energia

Foto 16: Praia Grande (llha de São Sebastião) - características reflexivas

Foto 17: Praia do Puruba - características reflexivas a intermediárias

Foto 18: Extremo sul da Praia de Massaguaçu - características reflexivas e morfologia em cúspide

Foto 19a: Extremo norte da Praia de Caraguatatuba - características intermediárias a dissipativas

Foto 19b: Detalhe da face sul do canal de saneamento da foto anterior, mostrando os efeitos da forte retrogradação da praia na morfologia praial

Foto 20: Vista geral da planície de maré arenosa no extremo sul da Praia de Caraguatatuba 
Foto 21: Extremo norte da Praia de Ubatumirim - características dissipativas de baixa energia com desenvolvimento de cúspides

Foto 22: Extremo norte da Praia de liha Comprida (ponto 15) mostrando casas destruídas na antepraia inferior

Foto 23: Erosão intensa em terraços marinhos holocênicos no extremo sul da liha Comprida (ponto 1)

Foto 24: Vista geral do extremo norte da liha Comprida

Foto 25: Erosão de terraços marinhos holocênicos na área de retro-barreira da Ilha Comprida

Foto 26: Erosão intensa em terraços marinhos da Formação Cananéia, provocando o colapso de blocos fraturados

Foto 27a: Restos de uma casa completamente erodida na porção norte da Praia de Illa Comprida (próximo ao ponto $15 / 536 \mathrm{~A}$ )

Foto 27b: Restos de espigões de bolsa-roca construídos em meados de 1996 na porção norte da Praia de llha Comprida (pontos 15/536A a 536B)

Foto 28: Falésias na porção centro-norte (ponto 24/409) da Praia da Juréia

Foto 29: Cordão litorâneo formado no segmento norte da Praia do Rio Verde (1996) e terraço marinho holocênico escarpado

Foto 30: Vista geral atual do enrocamento do Rio Guaraú e do conseqüente prenchimento sedimentar do prisma praial (deriva litorânea de rumo sul)

Foto 31: Erosão nas praias do Arpoador e Guarauzinho

Foto 32a: Anteparo usado para conter o avanço das marés sobre casas na porção centro-sul da Praia de Peruibe

Foto 32b: Muretas construídas sobre a pós-praia ao sul de Peruibe.

Foto 33: Sistema de pavimentação de ruas usado no litoral paulista

Foto 34: Limpeza da praia com uso de equipamentos pesados e remoção de muita areia juntamente com o lixo

Foto 35: Erosão intensa na Praia do Itaguaré

Foto 36: Erosão em trecho urbanizado da Praia de Maresias

Foto 37: Restos de um anteparo de blocos de rocha na margem continental do

Canal de São Sebastião

Foto 38: Erosão intensa na porção sul da Praia de Caraguatatuba, com destruição do mangue e exumação de depósitos marinhos holocênicos

Foto 39: Exumação de depósitos paleolagunares holocênicos na antepraia e face litorânea da Praia de Tabatinga

Foto 40a: Intensa retrogradação da Praia da Barra Seca, com destruição da vegetação de restinga frontal

Foto 40b: Continüidade da forte retrogradação da Praia da Barra Seca, com soterramento e destruição do mangue

Foto 41: Alta falésia em terraço marinho holocênico na Praia Vermelha do Norte

Foto 42a: Forte erosão da praia que bordeja a planície de maré no extremo sul de Caraguatatuba

Foto 42b: Praia da planície de maré em 1985

Foto 43: Dois niveis de plataforma de abrasão marinha antigos $(+4 \mathrm{e}+6 \mathrm{~m}) \mathrm{com}$ retomada erosiva das ondas (Praia de Massaguaçu) 


\section{AGRADECIMENTOS}

Ao Prof. Dr. Kenitiro Suguio, pela orientação deste trabalho, pela amizade, pelas profícuas discussões e pelo constante apoio em todas as necessidades e dificuldades surgidas.

Ao Prof. MSc. Agenor Pereira Souza, marido, amigo e absolutamente companheiro em todas as etapas deste trabalho, executando pacientemente as tarefas mais árduas, porém sem nunca perder a ternura e o carinho.

Ao Instituto Geológico-SMA, na pessoa de sua diretora PqC. Márcia Maria N. Pressinotti, principalmente no que diz respeito à autorização concedida para o desenvolvimento da pesquisa e à utilização de laboratórios.

Aos técnicos do laboratório de sedimentologia do Instituto Geológico-SMA, Ivete Costa da Silva, Antonio Roberto de M. S. Drago e José Alvez Andrade, pela execução da análise granulométrica de cerca de $80 \%$ das amostras utilizadas neste trabalho.

Aos ex-alunos de geologia (bolsistas de iniciação cientifica), Kleber da Silva, Francis $P$. Hager e Luís F. Litordi, pela execução da análise granulométrica das amostras restantes no laboratório de sedimentologia do Instituto de Geociências-USP.

Ao amigo de tantos congressos... o Prof. Dr. Rodolfo J. Angulo (uma argentino brasileiro ou um brasileiro argentino?), da Universidade Federal do Paraná, pela leitura de parte deste manuscrito e pelas valiosas sugestões, além das calorosas discussões que certamente nunca terminarão por causa da teimosia mútua...

Ao amigo Prof. Dr. Paulo César F. Giannini, da Universidade Federal do Paraná, pela leitura do capítulo de abordagem metodológica e pelas proveitosas sugestões.

Ao Prof. Dr. Paolo Alfredini, do CTH-USP/DAEE, pelas interessantes discussões sobre o trabalho na Banca de Qualificação e em outros momentos.

Aos colegas do Instituto Geológico-SMA, os geólogos Geraldo Oda e Amélia Fernandes e as técnicas do laboratório de informática Sandra G. Moni de Souza e Rosângela $P$. de Carvalho, pelo apoio prestado durante a edição de mapas e figuras.

Às técnicas do laboratório de geoprocessamento do Instituto de Geociências-USP Rita P. Conde e Márcia C. da Ponte e ao Prof. Dr. Jorge K. Yamamoto, por tornarem possível a impressão dos mapas.

Ao casal de amigos e biólogos MSc. Wânia Duleba e PqC. Otávio Marques, pela divertida e proveitosa visita às praias da Estação Ecológica da Juréia-Itatins em 1996. abstract.

À colega Dra. Gianna M. Garda, do Instituto Geológico-SMA, pela versão do

Aos vários guarda-vidas do $18^{\circ}$ Grupamento de Bombeiros, principalmente ao seu comandante, o Tenente-Coronel Nelson F. Duarte, e demais oficiais de apoio, que compreenderam a seriedade e a importância deste trabalho colaborando dedicadamente 
na resposta ao questionário sobre as praias paulistas. Um agradecimento especial é devido ao $2^{\circ}$ Sargento Otávio da Cruz (Ubatuba), pelo incentivo à elaboração e aplicação deste questionário e pela dedicação em respondê-lo.

Ao IBAMA, através da Superintendente estadual Nilde L. Pinheiro, pelos convites para participação em reuniões com prefeitos e técnicos de prefeituras do litoral para discutir questões ligadas à retirada de areia das praias paulistas e ao desassoreamento de desembocaduras fluviais e de canais de drenagem.

Ao Ministério Público do Estado de São Paulo, especialmente através dos promotores do litoral, por solicitarem suporte técnico e a elaboração de laudos técnicos, permitindo a discussão e a divulgação dos problemas e impactos decorrentes da retirada de areia das praias e do desassoreamento de desembocaduras fluviais e canais de drenagem.

Aos colegas e técnicos do DEPRN-SMA e do Instituto de Botânica-SMA e a todos os membros da Comissão Especial de "Políticas Florestais" do CONSEMA, pela oportunidade de fornecer suporte técnico e divulgar a importância das praias, da geologia, da geomorfologia e da drenagem costeiras no ecossistema restinga e pelas proficuas discussões sobre 0 assunto.

Ao engenheiro-geólogo Alexandre M. S. Maximiano, pela digitalização dos mapas.

À Sra. Maria de Lourdes F. Gomes e ao Sr. Antonio de O. Piedade, do Instituto Geológico-SMA, por parte dos serviços de xerox. Aos técnicos da gráfica do Instituto de Geociências-USP, por parte do serviço de xerox e pela encadernação dos volumes.

À FAPESP (processos 91/4940-7 e 92/4840-6), ao CNPq (processo 800944/92-5) e à CAPES, pelo suporte financeiro e pela concessão de bolsas de pesquisa e iniciação cientifica.

A todos aqueles que de uma maneira ou de outra colaboraram na execução deste trabalho mas que, embora não citados nominalmente, sempre terão meu agradecimento.

Um agradecimento especial é dedicado aos meus sogros, Elias e Ida, pelo constante apoio.

Finalmente, mas nunca por último, um agradecimento "dez" à minha querida Flora ("Baixinha"), que do seu jeitinho todo especial e uma inesgotável compreensão sempre me apoiou carinhosamente, sendo companheira também em trabalhos de campo e nas intermináveis tarefas de finalização deste trabalho, dentro e fora de nossa casa.

Muito obrigado! 


\section{RESUMO}

O presente trabalho versa sobre a caracterização morfotextural de 64 principais praias do Estado de São Paulo, compreendidas entre os municípios de liha Comprida e Ubatuba. O objetivo principal do trabalho consistiu na identificação das mais importantes células de circulação costeira atuantes neste litoral, bem como no diagnóstico das causas de processos erosivos instalados na costa.

Os trabalhos de campo foram efetuados no inverno de 1992 e no verão de 1993, tendo sido levantados 348 perfis de amostragem, nos mesmos locais nas duas etapas. Para este trabalho foram analisadas 1050 amostras de sedimentos praiais, distribuídas entre amostras de inverno e de verão. Durante estas etapas foi possível observar o comportamento das praias e das ondas sob diferentes condições meteorológicas e de maré astronômica.

O litoral paulista foi caracterizado quanto aos estados morfodinâmicos de suas praias e compartimentado em sete setores morfodinâmicos. A apresentação de todos os resultados do trabalho foi feita com base nessa subdivisão.

Foram empregados três métodos de estudo, envolvendo a análise de produtos de sensoriamento remoto (fotografias aéreas e imagens de satélite em papel) e a análise de parâmetros morfológicos e texturais das praias. Entre estes parâmetros, a largura e a inclinação praiais, o diâmetro médio, o desvio padrão e a curtose dos sedimentos foram utilizados no método de TAGGART \& SCHWARTZ-modificado, enquanto que o diâmetro médio, o desvio padrão e a assimetria foram usados no método de McLAREN. O método de TAGGART \& SCHWARTZ-modificado foi muito eficiente na identificação de pequenas e grandes células de deriva litorânea atuantes nas praias, especialmente em praias com acentuada homogeneidade morfológica e textural. $O$ método de McLAREN foi particularmente útil na identificação de tendências regionais de transporte entre as praias de cada setor morfodinâmico e, também, na caracterização de áreas com predominância de erosão ou deposição. Em geral, os locais onde foram observados processos erosivos, no campo, puderam ser correlacionados a zonas de barlamar ou a centros de divergência de células de deriva litorânea e/ou a trechos que correspondem a áreas-fonte da muitas outras praias, mas que não apresentam fontes locais.

As causas dos processos erosivos na costa paulista puderam ser relacionadas a fatores naturais como, zonas de barlamar de células de deriva litorânea e elevação de nivel do mar, e a fatores antrópicos, como a ocupação inadequada da orla, a construção de estruturas rígidas na linha de costa e a extração de areia de praia.

A comparação entre cartas náuticas antigas e recentes permitiu a identificação de tendências claras e generalizadas na plataforma continental de São Paulo, de deslocamento das curvas batimétricas no sentido costa afora e conseqüente diminuição da declividade da plataforma. Estas tendências caracterizam respostas à dinâmica de sedimentação de costa submetida à elevação de nível do mar, ou seja, a Regra de Bruun. 


\section{ABSTRRACT}

This Ph.D. thesis focuses on the morphotextural characterization of 64 major beaches of São Paulo State (Brazil), localized between the liha Comprida and Ubatuba municipalities. The main objective of this work is both the identification of the most important coastal circulation cells active along the littoral and a diagnosis of the causes of coastal erosive processes installed.

Field work was carried out during the winter of 1992 and the summer of 1993, including sampling of the same 348 profiles in each season, totallizing 1,050 samples of beach sediments. During both filed work stages it was possible to study the behaviour of the beaches and waves under different meteorological and tidal conditions.

The São Paulo littoral was characterized according to the morphodynamic states of its beaches and divided into seven morphodynamic sectors, used as basis for the presentation of all data and results.

Three methods of study were employed, including the analysis of remote sensing products (aerial photographs and satellite images in paper) and the analysis of morphological and textural parameters of the beaches. Among these parameters, the width and gradient of the beaches and the average diameter, the standard deviation and curtosis of the sediments were used in the TAGGART \& SCHWARTZ's method, modified to São Paulo littoral conditions, whereas the average diameter, standard deviation and asymmetry were used in the MCLAREN's method. The (modified) TAGGART \& SCHWARTZ's method proved very efficient in the identification of small and large cells of coastal drift active in the beaches, especially in those with high morphological and textural homogeneity. The MCLAREN's method was particularly useful in the identification of regional trends of sediment transportation between beaches of a certain morphodynamic sector and also in the characterization of areas where either erosion or deposition predominates. As a whole, it was possible to correlate the sites where erosion processes were observed with the zones of updrift or with divergency centers of coastal drift cells and/or to parts of source areas which supply sediments to several other beaches which lack local sources.

The causes of erosive processes along São Paulo coast can be correlated with natural factors, such as zones of updrift of coastal drift cells and the rise of the sea-level and to anthropic factors, such as the inappropriate occupation of the shore, the construction of rigid structures on the shoreline and the exploitation of beach sand.

The comparison between old and recent nautical charts allowed the identification of clear and widespread trends in the São Paulo continental shelf, which are the dislocation of bathymetric curves offshore and the resulting decrease in the continental shelf gradient. These trends characterize the answers to the sedimentation dynamics of the coast submitted to sea-level rise, in other words, the Bruun's Rule. 


\section{INTRODUÇÃO}

Este trabalho versa sobre as caracteristicas morfotexturais das principais praias do Estado de São Paulo, compreendidas entre liha Comprida e Ubatuba.

A área de estudo (figura 1 - Volume II) abrange, de sul para norte, os municipios de Ilha Comprida, Cananéia, Iguape, Peruibe, Itanhaém, Mongaguá, Praia Grande, São Vicente, Santos, Guarujá, Bertioga, São Sebastião, llha Bela, Caraguatatuba e Ubatuba. Cerca de $3,9 \%$ da população do Estado de São Paulo vivem nesses municípios, perfazendo aproximadamente 1.300 .000 habitantes. Esse número se multiplica durante as férias de verão e inverno e feriados prolongados, principalmente na Baixada Santista, onde a populaçăo flutuante atinge cerca de 2.000 .000 pessoas.

A Baixada Santista, que reúne mais de $50 \%$ desses municípios (Peruibe, Itanhaém, Praia Grande, São Vicente, Santos, Guarujá e Bertioga), é a região mais densamente ocupada e industrializada. Além do Polo Petroquímico de Cubatão, está localizado nessa área o maior complexo portuário da América Latina. Nos litorais sul e norte do Estado, predominam as atividades turísticas. Destaca-se ainda o Terminal Petrolifero Almirante Barroso (TEBAR) situado junto ao Porto de São Sebastião. O Parque Estadual da Serra do Mar, geralmente limitado acima da cota de $100 \mathrm{~m}$, em algumas áreas adentra a planície costeira, como nos casos da Estação Ecológica Juréia-Itatins (Peruibe-Iguape) e do Núcleo Picinguaba (Ubatuba), onde as praias são pouco modificadas pelo homem.

No Estado de São Paulo a maioria das praias encontra-se ocupada, estando grande parte delas já totalmente urbanizada. Como conseqüência da ocupação inadequada houve eliminação de fontes naturais importantes de sedimentos para as praias, como as dunas e os depósitos marinhos frontais. A ocupação das planicies costeiras ocorreu de modo mais intenso nas duas últimas décadas, trazendo consigo uma série de modificações nos ecossistemas. Em vários locais da linha de costa foram construidas estruturas rígidas como espigões, enrocamentos, canais de drenagem e saneamento, muretas/muros, quebramares, etc. Todas essas intervenções têm causado mudanças no balanço sedimentar que, associadas ainda a fatores naturais, como variações climáticas e oscilações relativas do nivel do mar, trazem fortes desequilibrios na estabilidade das praias. Portanto as praias, cuja existência depende desse balanço sedimentar, são as mais impactadas. 
Outro aspecto preocupante é a poluição das praias paulistas, tanto no que diz respeito ao lixo, quanto à concentração de coliformes fecais e substâncias químicas. Segundo boletins da CETESB toda a Baixada Santista e os municípios de São Sebastião, Caraguatatuba e o sul de Ubatuba têm a maioria de suas praias comprometidas pela balneabilidade. A dispersão desses poluentes está fortemente relacionada à dinâmica de circulação costeira, espalhando-os ou concentrando-os em determinados locais. 


\section{OBJETIVOS}

Além de toda a problemática relacionada à ocupação inadequada do litoral e as importantes modificaçōes impostas por ela às praias, outros aspectos também levaram às escolhas da área de estudo e da temática envolvida: (a) a grande maioria das praias paulistas não foi estudada quanto às suas características morfológicas, sedimentológicas ou morfodinâmicas; (b) são raros os trabalhos regionais ou que abordem questões ligadas à dinâmica sedimentar e à circulação de correntes costeiras; (c) os impactos causados por intervenções antrópicas na linha de costa são muitos e estão crescendo assustadoramente, causando prejuizos materiais e chamando a atenção das comunidades e autoridades; (d) as condições de balneabilidade das praias, prejudicadas pela propagação de águas poluídas junto à costa (provenientes do continente ou de emissários submarinos) e pela deposição de lixo urbano nas praias sem ocupação antrópica, também são preocupantes, mas raramente são tratadas à luz de conhecimentos da dinâmica costeira.

O objetivo principal desta pesquisa consistiu na tentativa de identificação das mais importantes células de circulação costeira, atuantes ao longo do litoral paulista, através da caracterização morfológica e textural de suas praias.

Outro importante objetivo foi o desenvolvimento de uma metodologia simples e econômica, suficiente para a obtenção de dados qualitativos e quantitativos, capazes de fornecer um diagnóstico sobre os processos sedimentares ocorrentes ao longo das praias paulistas. Neste sentido, foi possível compreender os mecanismos que estão causando a erosão costeira no Estado de São Paulo, entre os fatores fatores naturais (células de transporte costeiro, elevação atual do nivel relativo do mar etc.) e antrópicos (modificações no balanço sedimentar das praias ou na fisiografia costeira etc.).

Finalmente, espera-se que os resultados obtidos forneçam subsidios às obras de engenharia civil na linha de costa, aos projetos de desassoreamento de desembocaduras fluviais, à extração de areia das praias, à regulamentação do uso do solo, aos planos diretores municipais, aos programas de gerenciamento costeiro e ao macrozoneamento do litoral e, finalmente, à prevenção de acidentes por afogamento nas praias, auxiliando nos salvamentos marítimos. 


\section{A ÁREA DE ESTUDO}

\section{1. CONTEXTOS GEOLÓgICO, GEOMORFOLÓGICO, CLIMÁTICO E OCEANOGRÁFICO REGIONAIS}

\section{1. 1. GEOLOGIA}

As caracteristicas geológicas atuais do litoral paulista têm sua história iniciada no Mesozóico, quando da abertura do Oceano Atlântico Sul no Jurássico-Cretáceo, seguida pelo soerguimento da borda continental e pela instalação da Bacia de Santos. Durante todo - Cretáceo e o Terciário ocorreu intensa sedimentação nesta bacia, controlada fortemente por eventos tectônicos, com soerguimento contínuo da margem continental, ativo até os dias de hoje, acompanhado por intensa subsidência das bacias marginais e variações do nivel relativo do mar.

Foi durante o Quaternário, que as planícies costeiras ganharam a geometria que guardam até hoje. Neste periodo ocorreram, pelo menos, quatro estádios glaciais alternando-se com interglaciais, os quais foram acompanhados de elevações e abaixamentos do nivel relativo do mar, cujos efeitos encontram-se registrados nas planicies costeiras sob a forma de cristas praiais de várias gerações (SUGUIO \& MARTIN, 1994). Eventos tectônicos de grande intensidade, durante este período, não são citados na literatura brasileira.

O litoral paulista é formado por planícies costeiras (planicies de cristas praiais) de sedimentos marinhos regressivos holocênicos e pleistocênicos, associados a depósitos lagunares, fluviais e coluviais holocênicos a atuais (SUGUIO \& MARTIN, 1978). Na linha de costa afloram essencialmente os depósitos marinhos mais jovens, de idade holocênica, superpostos ou não por dunas frontais inativas. Essas dunas ocorrem principalmente no litoral sul e vão perdendo expressão rumo ao norte, onde raramente encontraram condições propícias ao seu desenvolvimento. À retaguarda dos depósitos marinhos frontais, de sul para o norte do Estado, ocorrem: (a) um sistema de lagunas atuais, conhecido por complexo lagunar-estuarino de Cananéia-Iguape, encerrado atrás de uma grande ilha-barreira (MARTIN \& SUGUIO, 1978); (b) uma vasta planície de terraços marinhos pleistocênicos cobertos por depósitos eólicos holocênicos e/ou pleistocênicos(?), 
associados a ambientes fluviais modernos/holocênicos, e com uma estreita faixa frontal de depósitos marinhos holocênicos na região entre Peruibe e Praia Grande; (c) um sistema estuarino com vastos canais de maré que desembocam na Baía de Santos, conhecido como Estuário Santista, onde predominam terrenos marinhos holocênicos (São Vicente, Santos e Guarujá); (d) planícies costeiras de menor porte, com presença mais esparsa de restos de terraços marinhos pleistocênicos, cortadas por sistemas fluviais atuais geralmente instalados sobre pequenas lagunas holocênicas colmatadas, como ocorre na região entre Bertioga e Caraguatatuba; e, finalmente (e) planicies costeiras estreitas, onde afloram apenas depósitos marinhos holocênicos cortados por planícies fluviais jovens, como o trecho ao norte de Caraguatatuba até a divisa com o Estado do Rio de Janeiro.

Os depósitos marinhos pleistocênicos são conhecidos por Formação Cananéia (SUGUIO \& PETRI, 1973). Afloram com altitudes de cerca de 5 até $10 \mathrm{~m}$ e têm idade de 120.000 anos A.P. (Transgressão Cananéia - MARTIN ef al., 1988). Restos de terraços mais elevados de até $13 \mathrm{~m}$ de altitude, provavelmente construídos em evento transgressivo anterior ao dessa Formação, foram encontrados até o momento, apenas em Iguape (Icapara). SUGUIO \& MARTIN (1994) propõem a denominação de Formação Morro de Icapara para os mesmos. Os depósitos marinhos holocênicos, cujas altitudes variam de $4 \pm 0,5 \mathrm{~m}$ a $2 \pm 0,5 \mathrm{~m}$, são correlatos ao evento transgressivo-regressivo conhecido em São Paulo como Transgressão Santos (SUGUIO \& MARTIN, 1978). SUGUIO \& MARTIN (1994) propõem a designação formal desses depósitos de Formação liha Comprida.

Pode-se concluir, então, que as oscilações do nível relativo do mar foram um importante agente modelador das planícies costeiras e, conseqüentemente, das praias atuais. Outro fator geológico que, sem dúvida, também condicionou a morfologia do litoral paulista são as estruturas tectônicas do substrato rochoso. Por ocasião dos trabalhos de fotointerpretação e de campo pôde-se levantar uma série de dados estruturais (bandamentos gnáissicos, foliações miloníticas, juntas, alinhamento de diques etc.) e geomorfológicas (alinhamentos de cristas e escarpas, facetas trapezoidais e triangulares, lineamentos de drenagem etc.), sugestivos da influência tectônica (falhas mesozóicas e cenozóicas) e estrutural (erosão acentuada sobre descontinüidades rochosas) dessa linha de costa. Por outro lado, também os depósitos marinhos pleistocênicos e holocênicos forneceram dados estruturais representados por fraturas penetrativas, preenchidas ou não por óxidos de ferro, e até por raras microfalhas, capazes de explicar, por exemplo, parte da morfologia atual da llha de Cananéia. Nesta, os grandes blocos abatidos devido à intensa 
erosão marinha ao seu redor desmontam segundo juntas neotectônicas verticais de direções N40-50E e N60-80W (SOUZA \& SUGUIO, 1996a) (vide capítulo VII).

\section{1. 2. GEOMORFOLOGIA}

A geomorfologia do litoral se São Paulo resulta de sua evolução geológica, associada às oscilações do nível relativo do mar durante o Quaternário.

O litoral paulista apresenta características morfológicas distintas entre o setor sul e o norte. Ao sul, a costa é aberta, as planícies costeiras de cristas praiais e as praias são bem desenvolvidas, estando a Serra do Mar dezenas de quilômetros afastada da linha de costa. Ao norte, a Serra do Mar aproxima-se do oceano definindo uma linha de costa bastante recortada, com planícies costeiras e praias estreitas.

A antiga Comissão Geográfica e Geológica do Estado, em sua "Exploração do Littoral" (C.G.G., 1915, 1920), já havia atentado para essa variação morfológica. DEFFONTAINES (1935) reconheceu duas regiões bem definidas, as quais denominou costa leste (Santos à divisa com o Rio de Janeiro) e costa oeste (Santos à divisa com o Paraná). A primeira atribuiu características de costa recortada e à outra, de costa retilinea. FREITAS (1947) fez menção à morfologia costeira, atribuindo-os a fatores tectônicos. ALMEIDA (1964) interpretou essas variações morfológicas como devidas principalmente à erosão diferencial das rochas do embasamento cristalino.

O compartimento litorâneo foi denominado por ALMEIDA (1964) como Província Costeira. PONÇANO et al. (1981) subdividiram a Província Costeira em três zonas: Serrania Costeira (Serra do Mar), Baixada Litorânea (planícies costeiras) e Morraria Costeira (morros isolados ou conjuntos de morros dispersos nas planícies costeiras). A Serrania e a Morraria costeiras condicionam o alinhamento NE-SW da costa paulista, entremeando os segmentos de praia.

Uma das primeiras tentativas de classificação de costa para São Paulo foi feita por FÚLFARO \& PONÇANO (1974), que sugeriram características de costa de emersão para o litoral sul, e de submersão para o litoral norte. Os autores adotaram, portanto, a classificação de costas de JONHSON (1919) e citaram grandes estruturas tectônicas, que estariam condicionando a esculturação do relevo por erosão a partir da rede de drenagem 
fluvial. Reconheceram três grandes compartimentos com basculamentos de blocos diferenciados: sul, central e norte.

SUGUIO \& MARTIN (1978), considerando os limites mais importantes do embasamento pré-cambriano, de sul para norte, e usando critérios basicamente geomorfológicos das planicies costeiras, reconheceram quatro unidades morfológicas: Cananéia-Iguape, Itanhaém-Santos, Bertioga-Ilha de São Sebastião e Caraguatatuba-

- Ubatuba. Os autores atribuíram as variações morfológicas a diferenças na dinâmica de sedimentação e a atividades tectônicas.

SOUZA \& SUGUIO (1996a), baseados no comportamento morfodinâmico das principais praias paulistas e sua relação com a evolução das planícies costeiras, apresentaram uma compartimentação do litoral em sete setores morfodinâmicos (figura 2 Volume II): Setor I - Itha Comprida a Juréia; Setor II - Rio Verde a Guaraú; Setor III Peruibe a Praia Grande; Setor IV - São Vicente a Iporanga; Setor V - Bertioga a Barequeçaba; Setor VI - Canal de São Sebastião; Setor VII - Caraguatatuba à divisa do Estado do Rio de Janeiro.

\section{1. 3. CLIMA}

Segundo FONSAR (1994) a circulação atmosférica no sul da América do Sul é controlada pelo Anticiclone Tropical Atlântico (ATA), quente e estacionário, e pelas incursões dos anticiciones migratórios frios como o Anticiclone Polar Atlântico (APA).

O Estado de São Paulo se encontra em uma faixa de transição onde ocorre o confronto entre os climas controlados pelos sistemas tropicais e extra-tropicais (polares), além dos fenômenos frontológicos (SANT'ANNA NETO, 1994). De acordo com MONTEIRO (1973, apud SANT'ANNA NETO, 1994), na costa do Estado de São Paulo atua, durante $O$ ano todo, a Massa Tropical Atlântica que é originária da ATA e está associada a ventos alísios de direção E e NE. O APA é representado pela Massa Polar Atlântica (PA), pela Massa Polar Velha (PV) e pela Frente Polar Atlântica (FPA). Durante a PA atuam ventos de SW-S-SE, que mudam para E e NE na PV. A FPA, conhecida como frente fria, é provocada pelo choque entre as sistemas tropicais e polares, sendo mais rigorosa no inverno, mas podendo ocorrer durante o ano todo. 
MONTEIRO (1973, apud SANT'ANNA NETO, 1994) dividiu o litoral em três subunidades: litoral sul, litoral central e litoral norte.

- Litoral sul (Cananéia a Peruíbe): área controlada por massas tropicais e polares, caracterizada por grande variação de pluviosidade (associada à alternância entre grandes planícies e maciços isolados), forte participação das massas polares e passagens frontais, e distribuição quantitativa das chuvas variando de acordo com a topografia (vales, encostas e litoral).

- Litoral central (Itanhaém a Maresias): controlado por massas tropicais e polares, de clima úmido na face oriental, e subtropical, com aumento de participação das massas polares onde a serra se aproxima da costa (orientação W-E), na porção ocidental. Isto aliado à direção oposta das correntes perturbadas de sul, faz com que este trecho ocidental seja a área de maior pluviosidade do Brasil (cerca de $4.000 \mathrm{~mm} / \mathrm{ano}$ ).

- Litoral norte (São Sebastião a Ubatuba): controlado por massas tropicais e equatoriais, com clima úmido, sujeito à menor participação das massas polares (30-40\%) e, portanto, menos frio. A maior proximidade da Serra do Mar em relação à costa é responsável pela acentuada pluviosidade (efeito orográfico), mesmo no inverno.

SANT'ANNA NETO (1994), estudando três anos de variações climáticas diferenciadas (1881- habitual; 1983-chuvoso; 1985- seco), concluiu que o litoral sul é a área de maior atividade das massas polares, com numerosas passagens frontais, porém menos situações de frentes estacionárias. O litoral central define uma extensa zona transicional, ora associada aos mecanismos dominantes do setor sul, ora do setor norte. A participação dos sistemas tropicais e extratropicais é equilibrada. Quando o anticiclone marítimo se apresenta mais vigoroso e bloqueia as passagens frontais, esse litoral recebe maior intensidade de precipitações, pois as frentes tendem a recuar até essa área e permanecerem estacionárias antes de se dissiparem. Quando o ar polar é mais intenso, empurra as frentes para o norte, fazendo chover menos. A área entre Bertioga e Maresias, com orientação $\mathrm{W}-\mathrm{E}$, fica mais exposta às frentes polares, resultando em maior pluviosidade. No litoral norte, a latitude e o relevo são responsáveis pelo enfraquecimento das evoluções das frentes, mas as precipitações aumentam em função das frentes estacionárias que atuam na área. 


\section{1. 4. OCEANOGRAFIA}

A costa paulista apresenta um regime de micromarés $<2 \mathrm{~m}$, segundo a classificação de DAVIES, 1977), do tipo semi-diurno com desigualdades diurnas. Esse tipo de regime de maré, via-de-regra, exerce pouca influência como processo físico nas praias ou modificação das correntes. No entanto, de acordo com ROSE (1977, apud TAGGART \& SCHWARTZ, 1988), em regiões de micromarés a erosão é maior porque a energia das ondas é concentrada sobre uma pequena área ou ponto ao longo do perfil praial.

As ondas $e$ as correntes geradas por ondas exercem papel fundamental nas modificações morfológicas e sedimentológicas das praias do litoral paulista, o qual pode ser caracterizado como dominado por ondas, visto que as marés têm influência secundária.

Os ventos são o principal agente formador de ondas no oceano, conhecidas por ondulações (swells). As ondas incidentes, também conhecidas como gravitacionais, são as mais regulares, têm direção de propagação bem definida e apresentam pequena esbeltez, período longo e cristas arredondadas. Ondas geradas por ventos locais, chamadas de vagas (sea waves), são irregulares e apresentam características opostas às anteriores. Um terceiro tipo de ondas, as secundárias, são geradas a partir do movimento e energia das ondas gravitacionais. A energia da onda refletida na face praial pode ser reintegrada ao oceano ou ficar aprisionada na zona costeira. As ondas de ressonância (edge waves) estão presentes ao longo da zona de surfe e são produto dessa energia aprisionada na costa.

Do exposto no item sobre a circulação atmosférica na costa de São Paulo, pode-se prever que durante a atuação da Massa Polar Atlântica e dos Sistemas Frontais sejam geradas ondulações de SSW, S e SSE. As ondulações de SE, E e NE estariam principalmente vinculadas à atuação da Frente Polar Velha (fase pós-frontal) e à Massa Tropical Atlântica.

No litoral de São Paulo, os levantamentos sobre climas de ondas são escassos e geralmente restritos ao litoral sul, entre liha Comprida e Peruibe. Os primeiros levantamentos remontam à década de 60 e foram feitos para a região de Cananéia/llha Comprida (GEOBRÁS, 1966, apud TESSLER, 1988). CTH-USP/DAEE (1973) também fizeram medições na mesma área. Levantamentos para a região da Juréia foram feitas por INPH/PORTOBRAS (1984, 1985 e 1988, apud BOMTEMPO, 1991) e BOMTEMPO (1991). Outras medições de curta duração (poucos meses) foram efetuadas pelo INPH para a região de Santos (SONDOTÉCNICA, 1977) e Praia Grande (LEAL NETO \& ACCETTA, 
1995). Em todos esses levantamentos ficou bem caracterizada a predominância de ondulações do quadrante SE ao longo do ano todo, estando as ondas de SW-S-SSE associadas às passagens de frentes frias. SOUZA $(1990,1994)$, obteve as mesmas tendências para a região de Caraguatatuba, através de observações de campo e em fotos aéreas. SOUZA (1994, 1995a), usando as definições de JACOBSEN \& SCHWARTZ (1981) sobre ondas incidentes em regiões costeiras, concluiu que os sistemas de SE são "prevalecentes" (direção mais comum) e "predominantes" (influência mais efetiva) para a costa norte-paulista, sendo elas as principais reguladoras da dinâmica de circulação costeira nesse trecho. De acordo com DAVIES (1960), o principal gerador das ondulações de SE está no cinturão tempestuoso subpolar do Atlântico Sul, posicionado em torno da latitude $60^{\circ} \mathrm{S}$.

Os ventos locais parecem desempenhar papel pouco importante nas modificações das ondas que atingem a costa do Estado. TESSLER (1988) e BOMTEMPO (1991) chegaram a essa conclusão para o litoral sul, onde esses ventos são mais ativos em relação aos demais setores.

Outro agente importante no afeiçoamento das praias são as variações do nível relativo do mar. Essas variações podem ser em escala diária, semanal, mensal, sazonal, decenal/interdecenal (MESQUITA, 1995) e de longo periodo ( $>100$ anos). De acordo com MESQUITA (1994), as oscilações mensais (sizígia e quadratura) e diárias (preamar e baixamar) são aproximadamente iguais em toda a costa de São Paulo, chegando a alcançar quase $1 \mathrm{~m}$. As oscilações sazonais apresentam flutuações da ordem de $20-30 \mathrm{~cm}$ de amplitude, mas chegam a atingir $50 \mathrm{~cm}$ em Cananéia. Os máximos ocorrem nos meses de abril-maio, e os mínimos nos meses de verão (dezembro-janeiro) e em setembrooutubro. Segundo MESQUITA \& HARARI (1988) e MESQUITA (1994) na costa paulista os registros de marégrafos instalados em Ubatuba, Santos e Cananéia, têm sugerido uma elevação média do nivel do mar de cerca de $30 \mathrm{~cm}$ para o último século. Entretanto, segundo esses mesmos autores, para áreas oceânicas sulamericanas e africanas, essa elevação tem sido da ordem de $10 \mathrm{~cm}$, para o mesmo período. HARARI \& CAMARGO (1995) encontraram taxas de variação anual de elevação do nivel do mar de 0,1132 $\mathrm{cm} / a n$ para a região de Santos, a qual é bem inferior à obtida em Cananéia por MESQUITA et al. (1995), que é da ordem de $0,4 \mathrm{~cm} / a n o$. As taxas obtidas por esses autores para os registros de marégrafos de Cananéia, Santos e Ubatuba, são discutiveis por três aspectos principais: os dados remontam, no máximo, há cerca de 50 anos e as 
séries de dados têm várias lacunas; todos os marégrafos são "terrestres", ou seja, encontram-se instalados no interior de canais de maré; não são levados em consideração o contexto geológico e as intervenções antrópicas nas áreas onde os marégrafos estão instalados. As regiões de Cananéia e Santos, por exemplo, são áreas deprimidas e condicionadas por estruturas tectônicas conhecidas, como o Alinhamento de Guapiara e a zona de Falha de Cubatão, respectivamente, estando Cananéia inserida dentro de uma zona sismogênica (MIOTO, 1990). O Estuário Santista é fortemente antropizado e anualmente são dragados milhões de metros cúbicos de sedimentos do Canal de Acesso ao Porto e dos rios (SONDOTÉCNICA, 1977; CEPAIUSP, 1994). Ubatuba caracteriza-se por ser uma costa mais elevada e ingreme que as demais.

Em termos globais, vários autores citam uma elevação média de nivel do mar entre 10 e $15 \mathrm{~cm}$ para os últimos 100 anos, ou uma taxa anual média de 1 a $2 \mathrm{~mm}$ (GORNITZ, 1995). As estimativas futuras sugerem elevações entre 0,30 e 1,10 $\mathrm{m}$ até 0 ano 2.100 (WARRICK \& OERLEMANS, 1990, apud GORNITZ, 1995).

\section{2. SÍNTESE DE OUTROS LEVANTAMENTOS SOBRE A ÁREA DE ESTUDO}

Os trabalhos sobre as praias do litoral paulista são escassos. Encontram-se listados aqui os principais levantamentos realizados nessas praias ou dados relativos a medições de ondas e correntes. Para facilitar o entendimento do leitor adotou-se uma ordem de citação segundo uma organização geográfica, do titoral sul para o norte do Estado, e não cronológica.

BARCELOS (1975), BARCELOS et al. (1976) e TESSLER (1988) estudaram a Praia de Iha Comprida, principalmente quanto aos aspectos sedimentológicos, fazendo interpretações sobre o sentido principal da deriva litorânea, que seria para NE.

BOMTEMPO (1991) efetuou um levantamento sobre as ondas e correntes costeiras geradas por elas na área entre as praias do Rio Verde e Una, para o período de 1982 a 1985. MENEZES (1994) estudou o comportamento sedimentológico das praias da Estação Ecológica da Juréia-Itatins (praias do Rio Verde, Itacolomi, Una e Guaraú). 
A Praia de Peruibe foi estudada por GIANNINI (1987), quanto aos aspectos sedimentológicos e morfoscópicos, com interpretações sobre o sentido das correntes de deriva litorânea, que seria para NE.

Levantamentos sobre as ondas, marés e correntes costeiras foram feitos por HIDROCONSULT (1974/1975), CTH-USPIDAEE (1976) e SONDOTÉCNICA (1977), para a região da Baía de Santos e São Vicente e sul do Guarujá. PONÇANO \& FÚLFARO (1976) estudaram a distribuição dos sedimentos de fundo nesse trecho e fizeram interpretações sobre as correntes costeiras.

Algumas praias dos municipios de Bertioga e São Sebastião foram estudadas quanto à inclinação e granulometria por PIRES NETO \& OLIVEIRA (1976).

O litoral entre São Sebastião e Ubatuba foi estudado por FREITAS (1960a, 1960b), através da caracterização granulométrica e mineralógica das praias.

As praias de Caraguatatuba, Martim de Sá e Massaguaçu foram também estudadas por SOUZA (1990), que fez a caracterização morfológica e sedimentológica das mesmas, e utilizou o método de TAGGART \& SCHWARTZ (1988) para obter interpretações sobre os rumos das correntes de deriva litorânea atuantes no interior da Enseada de Caraguatatuba.

BIGARELLA et al. (1966) relacionaram a granulometria dos sedimentos praiais com a dos terraços marinhos adjacentes, para praias das Ilhas do Cardoso e Comprida e de Caraguatatuba a Ubatuba.

PONÇANO et al. (1994, in NAKAZAWA et al., 1994) elaboraram, para a Carta Geotécnica do Estado de São Paulo, uma carta em escala 1:500.000 contendo os rumos principais das correntes costeiras (figura 3 - Volume II). Segundo o autor (com. pessoal) esse trabalho foi elaborado a partir de levantamentos expeditos, baseados principalmente em observações visuais sobre as variações morfológicas e granulométricas das praias do litoral paulista, levando em consideração os indicadores geomórficos de TAGGART \& SCHWARTZ (1988).

Os resultados dos trabalhos de FREITAS (1960a, 1960b), BIGARELLA et al. (1966) e PIRES NETO \& OLIVEIRA (1976) não são usados para comparações com os obtidos nesta pesquisa, pois os métodos analíticos de laboratório e os parâmetros texturais utilizados são diferentes dos empregados aqui. 


\section{ABORDAGEM METODÓLÓGICA}

São abordados, a seguir, alguns conceitos básicos necessários à compreensão dos métodos usados e dos resultados obtidos.

\section{1. A PRAIA}

\section{1. 1. DEFINIÇÕES}

Praia è a "zona perimetral de um corpo aquoso (lago, mar, oceano), composta de material inconsolidado, em geral arenoso, que se estende desde o nivel de baixamar média para cima, até a linha de vegetação permanente (limite das ondas de tempestade), ou onde há mudanças na fisiografia, como zona de dunas ou falésias" (SUGUIO, 1992).

A praia é um dos ecossistemas mais frágeis do planeta e resulta da interação entre fatores oceanográficos e hidrológicos, meteorológicos e/ou climáticos, geológicos e antrópicos. É a zona de proteção do continente contra a ação destrutiva das ondas.

Existem vários termos em português usados para designar as partes constituintes de uma praia e também há muita discussão a respeito (SUGUIO, 1992; MUEHE, 1994; ANGULO, 1996). Nesta pesquisa foi adotada a seguinte subdivisão para a praia emersa: pós-praia (backshore), antepraia (foreshore) e face litorânea (shoreface). Informalmente, elas foram também chamadas de zonas supramaré, intermarés e inframaré. A pós-praia compreende a zona superior da praia, entre a antepraia e o limite inferior da planície costeira que pode ser reconhecido pela presença da primeira crista praial holocênica e/ou de dunas, com ou sem falésias. Nesta zona podem ou não ocorrer berma(s) e areias retrabalhadas pelo vento. Hidrodinamicamente, a pós-praia situa-se acima do nível de preamar médio (marés ordinárias), entre o limite de espraiamento das ondas de preamar médio e o alcance máximo das ondas de tempestade ou de marés extraordinárias. Em algumas praias ou em determinados locais de certas praias de São Paulo esta zona não foi observada. A antepraia situa-se entre a pós-praia e a face litorânea, estando portanto entre o limite superior de espraiamento das ondas de preamar médio (marés ordinárias) e o limite inferior da baixamar ordinária. A face litorânea está abaixo deste limite. 


\section{1. 2. Os Processos Costeiros}

A movimentação dos sedimentos e a modelagem morfológica das praias estão intrinsecamente associadas à atuação de processos oceanográficos físicos conhecidos por processos costeiros. Esses processos envolvem basicamente a ação das ondas, marés e ventos, além das correntes geradas por cada um desses fatores.

Como foi dito anteriormente, na costa paulista as ondas geradas em oceano aberto (ondulações) são os fatores mais importantes nos processos costeiros.

As ondulações que chegam à costa (ondas incidentes ou gravitacionais) sofrem o efeito de refração no fundo marinho, em função da diminuição de profundidade, e difração ao redor de obstáculos (ilhas, promontórios etc.). Esses fenômenos geram perturbações na direção de propagação das ondas (ortogonais), de tal modo que, quando as ortogonais convergem para um determinado local, há concentração de energia no mesmo, predominando a erosão e, por outro lado, quando as ortogonais divergem, há dispersão de energia, predominando a deposição. Outro fenômeno muito comum é a reflexão dos trens de ondas, quando encontram um obstáculo, gerando um novo trem de ondas, que acaba se superpondo ao anterior. As perturbações geradas pela difração e reflexão das ondas são freqüentes nos trechos de linha de costa recortada do litoral de São Paulo. Em fotografias aéreas observam-se determinadas situações em que é quase impossível reconhecer a direção original de propagação das ondulações, tal a intensidade de perturbação. Outra modificação que as ondulações sofrem, importantes para a dinâmica costeira, é o desenvolvimento de ondas secundárias produzidas a partir do movimento e energia das ondas gravitacionais na costa. A energia de onda refletida pela face da praia pode ser reintegrada ao oceano ou ficar aprisionada dentro da costa (standing waves), quando assume a forma de ondas de ressonância (edge waves). Estas ondas atuam ao longo da zona de surfe e são responsáveis por topografias rítmicas como as cúspides (GUZA \& INMAN, 1975). Quando mais de um trem de ondas atinge a linha de costa ao mesmo tempo, a interação ou interferência entre eles produz as ondas de infragravidade (infragravity waves).

A incidência de ondas na linha de costa gera grande variedade de correntes costeiras onde predominam as componentes paralelas à praia (KOMAR, 1991). O ângulo de incidência das ondas na praia determinará o tipo de circulação costeira. As componentes paralelas à praia são denominadas correntes longitudinais ou de deriva 
litorânea. Elas são mais ativas na zona de surfe e também são o principal agente de movimentação e retrabalhamento dos sedimentos ao longo da costa. Quando duas correntes longitudinais convergem para um ponto, ou há um forte desvio de uma corrente causado por algum obstáculo, tem-se o desenvolvimento de uma corrente de retorno concentrada. Esta pode transportar grande volume de sedimentos para costa afora.

A velocidade de uma corrente longitudinal varia principalmente em função do ângulo de incidência das ondas. Segundo LARRAS (1961, apud SUGUIO, 1992), as maiores velocidades são alcançadas quando o ângulo atinge entre 46 e $58^{\circ}$. Porém, de acordo com MUEHE (1994), ângulos superiores a $5^{\circ}$ são suficientes para produzir velocidades bastante eficientes.

O transporte de sedimentos na zona de surfe ocorre de maneira vetorial, sendo importante não só a corrente longitudinal, mas também os vetores gerados pela agitação das ondas no local. O movimento resultante é denominado deriva litorânea (TAGGART \& SCHWARTZ, 1988). Segundo estes autores, na zona de espraiamento das ondas (antepraia e face da praia) também há movimentação vetorial de sedimentos, com uma resultante chamada deriva praial, a qual assume uma forma serrithada com o mesmo sentido da deriva litorânea. Assim, o transporte resultante ao longo de uma praia, também denominado de deriva costeira resultante, tem a direção da corrente longitudinal e é produto dessas duas componentes: deriva litorânea e deriva praial. Essas relações são particularmente importantes para esta pesquisa, pois os trabalhos foram efetuados no prisma praial emerso, ou seja, da face praial à pós-praia. A deriva costeira resultante segue o sentido no qual a maioria dos sedimentos se move durante um longo período de tempo, a despeito da ocorrência de qualquer sentido oposto, menor ou sazonal de movimento.

Cada setor de costa com um determinado sentido de deriva costeira resultante forma uma célula de circulação costeira (NODA, 1971; JACOBSEN \& SCHWARTZ, 1981; TAGGART \& SCHWARTZ, 1988). Cada célula consiste de três zonas: (a) zona de erosão, onde se origina a corrente (barlamar) e, portanto, atua maior energia de ondas; (b) zona de transporte, através da qual os sedimentos são transferidos ao longo da costa; e (c) zona de deposição ou acumulação, onde a corrente termina (sotamar), havendo diminuição da energia das ondas. Quando duas células estão presentes, lado a lado, duas situações podem ocorrer: se a área for de terminação de duas células, então haverá convergência de correntes, podendo ocorrer intensa acumulação e/ou o desenvolvimento de uma terceira 
componente, a corrente de retorno; se o local for de divergência de correntes, ou seja, zona de barlamar de duas células, então predominará o processo erosivo. Segundo TAGGART \& SCHWARTZ (1988) uma célula de circulação costeira pode começar e terminar ao longo de um pequeno trecho, de poucas dezenas de metros, ou pode se prolongar por quilômetros de distância.

\section{1. 3. O Balanço Sedimentar nas Praias}

Os mecanismos sedimentares (erosão e deposição) que ocorrem em uma praia são produto de fatores oceanográficos e hidrológicos, meteorológicos e/ou climáticos, geológicos e antrópicos. Os dois primeiros já foram comentados anteriormente. Os fatores climáticos têm maior influência nas variações do nível relativo do mar (N.M.), sazonais e de longo período e, na modificação no sentido de propagação das ondas, podendo interferir temporariamente no rumo das correntes costeiras. Dentre os fatores geológicos atuantes no litoral, os de maior importância para as praias são os processos sedimentares responsáveis pelos ganhos (deposição) e perdas (erosão) de areia na praia, que podem ser associados ao seu balanço sedimentar. Os fatores antrópicos dizem respeito às interferências do homem nos ecossistemas costeiros, modificando os demais fatores.

O quadro 1 apresenta as possiveis relações entre as perdas e os ganhos de sedimentos em uma praia, ou seja o seu balanço sedimentar. Este quadro mostra que o balanço sedimentar de uma praia é bastante complexo e depende de uma série de fatores. Por outro lado, na prática, é muito difícil a quantificação de cada um dos termos listados.

A erosão das praias é um dos processos costeiros mais notados e tem se tornado um problema emergencial na maioria das costas ao redor do mundo. De acordo com BIRD (1985, apud BIRD, 1986), mais de $70 \%$ das costas arenosas do mundo estão em erosão, $10 \%$ estão sujeitas à progradação e os restantes $20 \%$ encontram-se em relativa estabilidade. As causas de processos erosivos costeiros têm sido amplamente discutidas na literatura. KOMAR \& ENFIELD (1987) e KOMAR (1991) sugerem ser o resultado de uma complexa interação de processos físicos, como a combinação dos movimentos das águas pelas ondas incidentes, marés, ondas de tempestade e correntes costeiras agindo sobre a costa. SHORT (1979) e WRIGHT \& SHORT (1984) acrescentaram a essa interação a importância do estado morfodinâmico da praia e zona de surfe como fator forçante nos processos erosivos de escala local e de curto período. Para BIRD (1986) e 
BRUUN \& SCHWARTZ (1985), entre outros, a erosão costeira pode ser produto de uma variedade de mecanismos como elevação do N.M., instabilidade tectônica, subsidência ou soerguimento isostático, mudanças climáticas (particularmente interferindo na intensidade e freqüência das tempestades e variações do N.M.) e causas antrópicas. KOMAR (1995) chama a atenção para outros importantes fatores que determinam a intensidade dos processos erosivos, como a suscetibilidade à erosão da praia, das dunas frontais e dos promontórios e/ou falésias, a dinâmica de circulação costeira (células de deriva litorânea e presença de correntes de retorno) e, até mesmo, a atuação do EI Niño que produz rápidas elevações do nível do mar com magnitudes excepcionais.

Quadro 1: Balanço sedimentar de uma praia (modificado de BIRD, 1986)

\begin{tabular}{|c|c|}
\hline SUPRIMENTO DE AREIA PARA A PRAIA & PERDA DE AREIA DA PRAIA \\
\hline areia dos rios e canais de maré & areia para os rios e canais de maré \\
\hline $\begin{array}{l}\text { areia proveniente dos costões rochosos, das } \\
\text { praias e dos depósitos marinhos frontais }\end{array}$ & $\begin{array}{l}\text { areia erodida e transportada pela deriva } \\
\text { litorânea }\end{array}$ \\
\hline areia da plataforma continental & areia da praia para a plataforma \\
\hline areia das dunas & areia levada pelos ventos \\
\hline alimentação artificial & extração/mineração de areia da praia \\
\hline $\begin{array}{l}\text { aumento no volume de sedimentos } \\
\text { produzidos no continente }\end{array}$ & $\begin{array}{l}\text { redução no volume de sedimentos } \\
\text { produzidos no continente }\end{array}$ \\
\hline
\end{tabular}

A grande maioria dos pesquisadores tem atribuido o processo atual e global de erosão costeira principalmente à elevação do N.M. BRUUN \& SCHWARTZ (1985) calcularam que a elevação do N.M. pode contribuir com 10 até $100 \%$ do total de erosão de uma praia.

\section{1. 4. Classificação de Praias}

A partir do final da década de 70 e começo dos anos 80 , surgiram as primeiras classificações que envolvem o estado modal das praias, caracterizando-as quanto: à 
morfologia do prisma emerso e da zona de surfe; à granulometria dos sedimentos; ao tipo de quebra, grau de energia e ângulo de incidência das ondas etc.

SAZAKI (1980, apud CARTER, 1988) elaborou um quadro (quadro 2) contendo as principais características das praias para os três estados morfodinâmicos: dissipativo, intermediário e reflexivo. WRIGHT ef al. (1979) e WRIGHT \& SHORT (1984) reconheceram dois estados morfodinâmicos extremos, o dissipativo e o reflexivo, e quatro estados intermediários entre eles.

No estado dissipativo a praia e a zona de surfe apresentam-se largas e com baixos gradientes topográficos, havendo elevado estoque de areias finas a muito finas, principalmente no prisma submerso (barras arenosas). Ocorre sob condições de ondas altas e de elevada esbeltez. No estado reflexivo os gradientes da praia e fundo marinho são elevados, praticamente não havendo zona de surfe. A berma da praia é elevada devido à velocidade de espraiamento e o estoque de areias médias a grossas ocorre essencialmente no prisma praial emerso, sendo baixo na zona submarina (ausência de barras). Os estados dissipativo e reflexivo têm baixa mobilidade (variabilidade temporal e espacial), enquanto que nos estados intermediários a praia e a zona de surfe são mais dinâmicas (SHORT \& HESP, 1982, apud WRIGHT \& SHORT, 1984). Nos estados intermediários a face da praia é mais ingreme que nos dissipativas, ocorrendo cúspides, bancos interrompidos e calhas.

SOUZA \& SUGUIO (1996a) basearam-se nas classificações de SAZAKI (1980, apud CARTER, 1988), WRIGHT et al. (1979) e WRIGHT \& SHORT (1984), para elaborar a compartimentação morfodinâmica do litoral paulista (figura 2 - Volume II) comentada no capítulo anterior. Esta compartimentação foi o ponto de partida para a apresentação dos resultados obtidos nesta pesquisa. 
Quadro 2: Principais características dos domínios morfodinâmicos praiais (modificado de SAZAKI, 1980, apud CARTER, 1988)

\begin{tabular}{|c|c|c|c|}
\hline & DOMIN & MORFODI & ÂMICO \\
\hline PARÂMETROS & DISSIPATIVO & INTERMEDIÁRIO & REFLEXIVO \\
\hline $\begin{array}{c}\text { Número de Quebras } \\
\text { Refletividade } \\
\text { Nivel Relativo de Energia } \\
\text { Ângulo de Incidência }\end{array}$ & $\begin{array}{l}\text { deslizante (spilling) } \\
\qquad 3 \\
\text { baixa } \\
\text { alto } \\
\text { normal à costa }\end{array}$ & $\begin{array}{c}\text { deslizante (spilling) - } \\
\text { mergulhante (plunging) } \\
1-3 \\
\text { médio } \\
\text { médio }\left(0-10^{\circ}\right)\end{array}$ & $\begin{array}{l}\text { mergulhante (plunging) } \\
\text { - frontal (collapsing) } \\
1 \\
\text { alta } \\
\text { baixo } \\
\text { obllquo }\left(10-45^{\circ}\right)\end{array}$ \\
\hline $\begin{array}{l}\text { CORRENTES } \\
\text { Horizontais } \\
\text { Costa afora }\end{array}$ & $\begin{array}{c}\text { grandes giros } \\
\text { grandes correntes de } \\
\text { retorno }\end{array}$ & $\begin{array}{c}\text { pequenos giros } \\
\text { médias correntes de } \\
\text { retorno }\end{array}$ & $\begin{array}{l}\text { unidirecional } \\
\text { fluxo rumo sotamar }\end{array}$ \\
\hline $\begin{array}{c}\text { MORFOLOGIA } \\
\text { Barras } \\
\text { Inclinação da praia e zona } \\
\text { submersa } \\
\text { Cúspides } \\
\text { Perfil Praial }\end{array}$ & $\begin{array}{l}\text { múltiplas, paralelas } \\
\qquad 2^{\circ} \\
\text { embaiamentos } \\
\text { rítmicos, aperiódicos } \\
\text { plano }\end{array}$ & $\begin{array}{l}\text { em crescente } \\
2-4^{\circ} \\
\text { cúspides de surfe } \\
\text { transicional }\end{array}$ & $\begin{array}{c}\text { sem barras } \\
>4^{\circ} \\
\text { cúspides de lavagem } \\
\text { (de maré) } \\
\text { em degraus }\end{array}$ \\
\hline $\begin{array}{c}\text { TRANSPORTE DE } \\
\text { SEDIMENTOS } \\
\text { Resultante ao longo da Costa } \\
\text { Costa adentro-Costa afora } \\
\text { Modo Dominante } \\
\text { Granulometria } \\
\text { Atividade Eólica }\end{array}$ & $\begin{array}{c}\text { baixo } \\
\text { alto } \\
\text { suspensão } \\
\text { fina } \\
\text { alta }\end{array}$ & $\begin{array}{l}\text { médio } \\
\text { médio } \\
\text { misto } \\
\text { média } \\
\text { média }\end{array}$ & $\begin{array}{c}\text { alto } \\
\text { baixo } \\
\text { carga de fundo } \\
\text { grossa } \\
\text { baixa }\end{array}$ \\
\hline
\end{tabular}




\section{2. MÉTOdOS DE TRABALHO}

A deriva litorânea pode ser variável em termos de sentido, tempo, lugar, duração e importância. Métodos de engenharia costeira e oceanografia utilizados para a determinação da deriva litorânea (cálculos a partir de dados de ondas e ventos, traçadores, corpos de deriva, armadilhas de sedimentos etc.) não levam em consideração todas essas variáveis. JACOBSEN \& SCHWARTZ (1981) e TAGGART \& SCHWARTZ (1988) sugeriram um método de estudo simples e econômico, baseado no comportamento morfológico e sedimentológico das praias. Os autores citam vários indicadores de deriva litorânea: variações de largura e inclinação da praia, variação granulométrica, morfologia de falésias, forma de baías e enseadas, estruturas que funcionam como armadilhas de sedimentos, crescimento de pontais arenosos, migração de desembocaduras fluviais e/ou lagunares e feições deposicionais associadas a essas desembocaduras, morfologia de cúspides praiais e barras costeiras.

Os métodos empregados aqui estão basicamente relacionados a esses indicadores, porém com maior ênfase ao comportamento dos sedimentos.

Não existe um método padronizado para o estudo morfo-sedimentológico de praias, principalmente em termos de trabalhos de campo. Nesta pesquisa, foram adotados procedimentos baseados em experiências positivas anteriores (SOUZA, 1990), somadas a adaptações fundamentadas nas literaturas nacional e internacional.

Os procedimentos metodológicos aqui empregados podem ser divididos em quatro grandes grupos: análise de documentos cartográficos e de sensoriamento remoto, trabalhos de campo, trabalhos de laboratório e tratamento dos dados.

\section{2. 1. ANÁlise DE DOCUMENTOS CARTOGRÁFICOS E DE SENSORIAMENTO REMOTO}

Documentos históricos, mapas, fotografias aéreas e imagens de satélite são normalmente utilizadas para avaliações sobre as variações morfológicas que as praias sofrem ao longo do tempo. As fotografias aéreas, embora representem um determinado momento dessa evolução, são os documentos disponiveis mais importantes. Além de retratarem com fidelidade as feições fisiográficas emersas, podem fornecer informações sobre as ondas, a morfologia da zona de surfe, o estágio da maré etc., quando em escalas apropriadas. Entretanto, elas retratam apenas condições de tempo bom. 


\section{Fotografias Aéreas}

O conjunto de aerofotos disponivel mais antigo, que abrange quase todo o litoral paulista, data de 1962 e tem escala de 1:25.000. Além da escala favorável, a época do vôo é interessante, pois muitas áreas ainda não estavam ocupadas ou urbanizadas. Entretanto, $a(s)$ época(s) do ano em que este vôo foi executado é desconhecida. O levantamento mais recente foi efetuado em 1994, também em escala 1:25.000, abrangendo a maior parte do litoral, entre Peruibe e Caraguatatuba. O quadro 3 mostra a relação dos conjuntos de fotos aéreas analisados.

A fotointerpretação permitiu obter as seguintes informações: variações de largura ao longo das praias; tipos de zona de surfe (presença de barras e canais); medida do rumo de propagação das ondas incidentes (ortogonal) e número de quebras prováveis (quando possivel); presença ou ausência de cúspides praiais; direção de crescimento de barras de desembocaduras fluviais e lagunares e de deriva dos canais; presença ou ausência de tômbolos; presença ou ausência de plataformas de abrasão marinha; assimetria de largura praial em relação às extremidades e ao seu arco ou nas faces de estruturas rígidas perpendiculares à linha de costa (espigöes, enrocamentos, canais de saneamento ou escoamento pluvial/fluvial etc.); presença ou ausência de plumas de sedimentos em suspensão; presença ou ausência de feições indicativas de erosão (obras de engenharia civil destruídas, recuos de linhas de vegetação de restinga ou de mangue marginais, falésias em terraços de cordões litorâneos etc.); e fase provável da maré. Cuidados com a fase da lua e das marés (sizígia/quadratura) e os eventos meteorológicos anômalos (frentes frias, ressacas) nos dias que antecederam ao vôo são importantes.

\section{Imagens de Satélite}

Dentre as imagens de satélite disponiveis em papel, as de junho de 1976 (LANDSAT-MSS, escala 1:500.000) são as únicas que abrangem todo o litoral paulista. Nas imagens de satélite em papel é possivel obter, com segurança, apenas os sentidos de transporte de plumas de sedimentos em suspensão.

O Guia de Praias da Revista Quatro Rodas (QUATRO RODAS, 1994) apresenta uma coletânea de excelentes imagens coloridas do satélite LANDSAT 5-TM para o litoral 
paulista. Apesar das datas de imageamento não serem apresentadas, sabe-se que são da década de 90 , segundo informações prestadas pelo INPE.

Quadro 3: Relação das fotografias aéreas utilizadas na pesquisa

\begin{tabular}{|c|c|c|c|}
\hline ANO DO VÓO (MÉS) & ESCALA & ÁREA ABRANGIDA & $\begin{array}{c}\text { EXECUTOR } \\
\text { (CONTRATANTE) }\end{array}$ \\
\hline 1962 (?) & $1: 25.000$ & $\begin{array}{c}\text { Todo o litoral paulista, exceto } \\
\text { Ilha Comprida }\end{array}$ & USAF \\
(Secr. Agricultura)
\end{tabular}

\section{Produtos Cartográficos}

As cartas náuticas da D.H.N. (Diretoria de Hidrografia e Navegação) podem fornecer informações interessantes sobre o comportamento da linha de costa e de variações da batimetria ao longo dos anos e, portanto, sobre áreas possivelmente sujeitas à erosão e à 
deposição. Foram utilizadas as cartas náuticas 1700 e 1600, ambas em escala aproximada de 1:300.000, nas suas edições antigas (respectivamente de 1939-1972 e 1938-1964) e recentes (respectivamente de 1994 e 1993). A carta náutica 1700 abrange os setores I, II, III, IV, V e VI, e a 1600 os setores VI e VII. Para avaliar as variações na sedimentação que vem ocorrendo na plataforma continental durante o período de abrangência dessas cartas, foi usado um método simples de comparação entre perfis traçados perpendicularmente à linha de costa, entre esta e a isóbata de $50 \mathrm{~m}$. A localização desses perfis foi escolhida de modo a representar regionalmente o maior número possivel de praias de cada setor, bem como os vários estados morfodinâmicos. A escolha da isóbata de $50 \mathrm{~m}$ foi feita com base no trabalho de COIMBRA et al. (1980), em que os autores estabeleceram que a partir dessa profundidade o fundo começa a sofrer os efeitos das ondas. Isto significa que este deve ser o limite aproximado de intercâmbio de sedimentos entre o litoral e a zona de costa afora. Cada perfil foi espacialmente representado em um gráfico de ordenada correspondente à profundidade (em metros) e abcissa correspondente à distância (em quilômetros) em relação à linha de costa. Esses perfis foram elaborados sem escala horizontal, para permitir uma fácil visualização das variações ocorridas, tanto no que se refere aos deslocamentos das isóbatas, quanto às variações de declividade apresentando, portanto, um exagero vertical muito grande. A declividade de cada intervalo de perfil (0-5 $\mathrm{m}$ ou $0-10 \mathrm{~m}, 5-10 \mathrm{~m}, 10-20 \mathrm{~m}$ e $20-50 \mathrm{~m}$ ) foi calculada em porcentagem, para facilitar a identificação das variações, o que certamente não seria possivel através da inclinação (graus), como foi usado para as praias. Obviamente, os valores obtidos estão sujeitos a imprecisões inerentes às técnicas de obtenção das cartas e ao próprio traçado dos perfis nesses mapas. As variações observadas puderam ser relacionadas à Regra de Bruun (BRUUN, 1962), que explica as respostas morfológicas de um perfil praial sujeito a elevação de nível do mar.

\section{2. 2. TRABalhos de CAMPo}

Os métodos empregados nos trabalhos de campo em praias variam de um autor para outro. Nesta pesquisa foram adotados procedimentos simples e de rápida execução.

Os trabalhos de campo foram desenvolvidos em duas fases, uma durante o inverno de 1992 (19 de junho a 22 de julho), e outra durante o verão consecutivo, em 1993 (02 de 
janeiro a 12 de fevereiro). Nas duas fases foram levantados perfis de amostragens e feitas várias medições nas praias, em locais determinados.

A escolha dessas duas fases de amostragem deveu-se às diferenças marcantes nos comportamentos meteorológico e climático entre ambas e também porque, segundo MESQUITA \& HARARI (1988), os maiores niveis mensais de maré na costa paulista ocorrem entre abril e maio. Além disso, pretendiamse testar a ocorrência ou não de variações morfológicas e/ou texturais marcantes nas praias, entre essas épocas do ano.

A tabela 1 (Volume II) mostra a relação das praias e os seus comprimentos, a identificação de cada perfil levantado e a orientação da praia no local, no inverno e no verão, para cada setor morfodinâmico. São também assinaladas as condições meteorológicas e de maré verificadas durante os trabalhos de campo.

Os critérios adotados para a escolha das praias amostradas, do número de perfis levantados em cada praia e da distância entre os pontos de coleta ao longo de cada perfil, foram: (a) representatividade da praia em relação ao setor do litoral em termos de dimensão e morfodinâmica; (b) tamanho da praia; (c) variações na morfologia ao longo da praia e do perfil praial, e (d) indicações sobre os limites das zonas intermarés e supramaré.

As praias escolhidas apresentam comprimentos $\geq 0,5 \mathrm{~km}$, exceto duas pequenas praias no Canal de São Sebastião (tabela 1).

O número de perfis levantados em cada praia variou conforme o tamanho da mesma e/ou em função das variações morfológicas observadas ao longo dela. Nas praias com comprimento de até $2 \mathrm{~km}$ foram executados de um a três perfis de amostragem, conforme os critérios citados anteriormente. Em algumas praias apenas um perfil foi levantado, na sua porção central, suficiente para sua caracterização sedimentológica e morfológica. Em praias com comprimento maior que $2 \mathrm{~km}$, o número de perfis variou, procurando-se manter uma eqüidistância entre eles no caso de praias com pouca variação morfológica, e uma amostragem em cada extremidade da praia, ou de acordo com a ocorrência de variaçōes morfológicas e sedimentológicas.

Cada local escolhido para o levantamento de um perfil foi orientado perpendicularmente à linha de costa e referido a pontos fixos na planície costeira e/ou no mar (ilhas, morros, quiosques de praia, endereços etc.), ou até mesmo ao odômetro do veículo, para os casos de praias muito longas ou sem outras referências. 
No que diz respeito às amostragens feitas em cada perfil, procurou-se coletar as amostras representativas das zonas de pós-praia (supramaré), de antepraia (intermarés) e da porção superior da face litorânea (inframaré), com o objetivo de melhor caracterizar o prisma praial emerso. Várias praias apresentaram problemas quanto à definição da póspraia, pois esta era inexistente em alguns locais, confundindo-se com a parte superior da antepraia. BIGARELLA et al. (1966) também observaram essa tendência para algumas praias do litoral paulista. Além disso, tendo em vista que todo o litoral foi percorrido durante um mês contínuo, tanto no inverno quanto no verão, as amostragens ocorreram também durante as fases de preamar de sizígia e de tempestade. Segundo MESQUITA et al. (1995) os registros para o periodo de 1955-1990 revelaram que, na área de Cananéia as marés de sizigia e tempestade têm sofrido uma elevação média da ordem de 0,57 cm/ano durante 0 mês de junho, e $0,19 \mathrm{~cm} / a n o$ em fevereiro. Para a área de Santos, HARARI \& CAMARGO (1995) encontraram taxas médias menores, de 0,18 cm/ano para os meses de inverno, e $0,03 \mathrm{~cm} / a n o$ para os meses de verão.

Assim, avaliando em cada praia as feições indicativas do nivel de maré máximo (linhas de deixa, marcas onduladas, bermas de maré, limite superior de cúspides etc.) na época da amostragem, pôde-se determinar o limite superior da antepraia ou limite inferior da pós-praia. O limite superior da praia foi determinado pela linha de jundu, ou pela presença de falésias em terraços e/ou dunas ou pela existência de estruturas rígidas (casas, muretas etc.). O limite inferior da antepraia foi de difícil determinação, conforme já comentado.

As amostras foram coletadas em profundidades entre 5 e $20 \mathrm{~cm}$ abaixo da superfície, procurando-se evitar as possíveis misturas de sedimentos devidas a atividades antrópicas. Os sedimentos assim amostrados certamente não representam a fase de deposição correspondente às condições meteorológicas vigentes no momento das coletas. Para isso seriam necessárias amostragens de lâminas superficiais dos sedimentos. Entretanto, nem assim estaria garantida a equivalência entre as condições vigentes e a fase de sedimentação correlata. Deste modo, as amostras coletadas são suficientes para representar o padrão médio dos sedimentos em pelo menos um período sazonal. $\mathrm{Na} z o n a$ inframaré os pontos de amostragem foram locados em sítio submerso com cerca de $20 \mathrm{~cm}$ de lâmina de água. Procurou-se, com isto, atingir a faixa de recuo máximo das ondas na face litorânea, posição esta que, segundo BIGARELLA et al. (1961), corresponde ao nivel médio do mar no momento da observação. 
Além das amostragens, em cada perfil foram feitas as seguintes medições:

(a) direção de orientação do perfil (perpendicular à linha de costa), obtida com bússola tipo Brunton;

(b) distâncias entre os pontos amostrados e largura total da praia, medidas com trena;

(c) ângulo de inclinação da praia em cada zona amostrada e em pontos de maiores variações, obtidos com bússola tipo Brunton;

(d) direção aproximada de propagação das ondas (ortogonal) obtida com bússola tipo Brunton;

(e) posição do limite atingido pelo nivel máximo de maré (em geral, maré noturna).

Foram observados ainda outros aspectos importantes para a caracterização das praias e do sentido de transporte ao longo delas:

(a) evidências de processos de erosão costeira;

(b) evidências de processos de deposição praial ou de assoreamento, nas extremidades das praias e em desembocaduras fluviais e lagunares, ou de canais de drenagem;

(c) caracterização da pós-praia e do tipo de limite com a planície costeira (muros, falésias em terraços e/ou dunas etc.);

(d) presença de depósitos marinhos antigos e de dunas junto à linha de costa e variações morfológicas dos mesmos ao longo da praia;

(e) presença de falésias em terraços atuais/subatuais de construção marinha e identificação de seus materiais;

(f) presença de bermas, cúspides praiais, barras de desembocadura fluvial, marcas onduladas e outras feições;

(g) presença de estruturas artificiais rígidas paralelas ou perpendiculares à linha de costa e modificações impostas por elas;

(h) presença de obras ou estruturas destinadas à contenção de erosão costeira ou de fluxos de areias retrabalhadas pelo vento; 
(i) presença de plataformas de abrasão marinha antigas, com observações sobre sua cota, colonização por organismos sésseis (natureza dos organismos e os niveis de fixação) e o nivel máximo de ataque atual das ondas;

(j) presença e quantidade de lixo (natural ou antrópico), procurando determinar sua proveniência;

(k) evidências de extração de areias das praias, dunas ou terraços marinhos;

(1) grau de ocupação da linha de costa e modificações decorrentes;

Na região de Ilha Comprida, Cananéia e Iguape, foram realizadas visitas ao interior das planicies costeiras, principalmente às margens dos canais lagunares e fluviais (Mar Pequeno, de Cubatão e de Cananéia, Rio Ribeira de Iguape), para observações sobre processos erosivos nos depósitos holocênicos e pleistocênicos.

Em dezembro de 1994 foi efetuada uma breve viagem pelas principais praias, para medições de ondas (direções) e averiguações quanto a modificações ocorridas após a visita anterior. Em junho de 1996 as praias da Estação Ecológica da Juréia-Itatins (Rio Verde e Una-Sul) foram visitadas pelas mesmas razões acima enumeradas. Várias outras praias, ao longo de todo o litoral, foram visitadas em outras épocas.

As amostras com numeração inferior a 300 correspondem à etapa de inverno (junho a julho/1992). Aquelas com numeração entre 300 e 525 foram coletadas durante o verão (janeiro/fevereiro/93). As amostras de numeração superior a 527 correspondem a viagens de observação feitas em 1994 (dezembro) e 1996 (junho).

Dentre as mais de 1500 amostras coletadas para este trabalho, foram extraviadas a de $n^{\circ} 191$ correspondente à coleta de inverno na Praia do Lázaro (Ubatuba) e a de $n^{\circ} 382$, correspondente à amostra de verão no extremo norte da Praia do Una-Sul (Iguape).

\section{2. 3. Trabalhos de Laboratório}

O metódo de análise granulométrica empregado neste trabatho baseou-se no descrito em SUGUIO (1973), com algumas modificações, tendo-se usado cerca de $50 \mathrm{~g}$ de material para o processamento, com eliminação prévia do calcário biodetrítico (SOUZA, 1990), seguida de peneiramento a seco. 
As análises convencionais de assembléias de minerais pesados não foram executadas neste trabalho pelas razões básicas descritas a seguir.

a). O objetivo deste trabalho foi a utilização de uma metodologia simples, rápida e econômica, o que não seria possível com o emprego dessas análises.

b). A ausência de estudos no prisma praial submerso restringe as possibilidades de determinação das fontes atuais desses minerais, que podem estar no fundo marinho adjacente.

c). A existência de múltiplas fontes desses minerais poderia mascarar os resultados obtidos ao longo de uma determinada praia e, por conseguinte, alterar as conclusões sobre o rumo da deriva litorânea.

d). NODA (1971) apresenta uma série de problemas relacionados ao uso de minerais pesados como traçadores naturais de deriva litorânea, sugerindo ser melhor aplicável a áreas onde há apenas uma única fonte desses minerais .

e). Muitos autores associam as concentrações de minerais pesados nas praias a processos erosivos, porém são poucos os estudos conclusivos (FRIHY \& DEWIDAR, 1993).

\section{2. 4. TRATAMENTO DOS DADOS}

Todos os dados obtidos tiveram como objetivo final a indicação do(s) sentido(s) de deriva litorânea ou transporte costeiro. Assim, os produtos finais compreendem mapas onde esses sentidos podem ser visualizados (Volume II).

Os dados obtidos através de fotografias aéreas, imagens de satélite e mapas são basicamente qualitativos. Transformar alguns desses dados em quantitativos, seria bastante interessante. Poder-se-ía, por exemplo, efetuar reconstituições a partir de vários conjuntos de fotos aéreas, com o objetivo de diagnosticar processos erosivos $e$ deposicionais, através de medidas de largura ou área das praias. Alguns autores têm feito isto usando também mapas antigos. Entretanto, os erros envolvidos podem ser muito grandes, principalmente em termos horizontais (TANNER, 1978, apud CARTER, 1988), dadas as inúmeras variáveis que podem estar envolvidas (fases de maré mensal, diária, sazonal; distorções das fotografias aéreas; condições meteorológicas anteriores ao vôo, largura da zona de arrebentação etc.). 
Os dados obtidos através dos trabalhos de campo são predominantemente qualitativos e correspondem aos parâmetros morfológicos e texturais.

Os sentidos de propagação das ondas, medidos no campo e nas fotografias aéreas, embora sejam dados isolados, podem indicar tendências de transporte na época da observação. Além disso, têm razoável valor estatístico quando comparados em conjunto. É importante ressaltar, entretanto, que nessas medições podem estar embutidos vários erros vinculados à própria medição, ao posicionamento geográfico, a distorções em fotografias aéreas, a interferências provocadas pela incidência de mais de um trem de ondas etc.

Os comportamentos morfológico e textural das praias foram avaliados em relação às variações ao longo das mesmas, para interpretações quanto às tendências de deriva praial e, portanto, de células de circulação costeira, segundo a metodologia de TAGGART \& SCHWARTZ (1988).

Os parâmetros morfológicos analisados foram a largura da praia e a inclinação nas três zonas. As caracteristicas granulométricas dos sedimentos praiais foram avaliadas a partir dos parâmetros estatísticos de FOLK \& WARD (1957): diâmetro médio, desvio padrão (grau de seleção), assimetria e curtose. O significado geológico dos dois primeiros é consenso entre os autores, tendo os seus usos se tornado indispensáveis em qualquer trabalho de sedimentologia. Os significados da assimetria e da curtose, apesar de menos compreendidos, têm sido amplamente discutidos na literatura. VALIA \& CAMERON (1977), MCLAREN (1981) e BITTENCOURT (1992) fizeram retrospectos sobre o uso e significado geológico da assimetria, testando-a em vários ambientes, embora não tenham chegado a um consenso. A curtose $(K)$ tem sido relacionada com sucesso, por vários pesquisadores, ao nível de energia de ondas, ambos sendo inversamente proporcionais (TANNER, 1995): valores leptocúrticos ( $K$ alta) indicam baixa energia de ondas, enquanto valores platicúrticos ( $\mathrm{K}$ baixa) sugerem alta energia.

Cada um desses parâmetros foi colocado em um gráfico de variação, para o inverno e para o verão, contendo os dados relativos às três zonas praiais (supra, inter e inframaré), para todos os perfis levantados em cada praia (Volume II). 


\section{Método de TAGGART \& SCHWARTZ-modificado}

Os indicadores de TAGGART \& SCHWARTZ (1988) para interpretações do sentido da deriva litorânea são basicamente constituídos de quatro parâmetros: largura da praia, inclinação da praia, diâmetro médio (tamanho dos grãos) e grau de seleção dos sedimentos. A relação entre as zonas de barlamar (origem) e sotamar (terminação) de uma célula de deriva litorânea, como idealizada por esses autores, apresenta as seguintes variações: aumento da largura, diminuição da inclinação, afinamento dos grãos e melhora no grau de seleção, de barlamar para sotamar. Os autores atribuem essas características à diminuição de energia de ondas ao longo da célula. MCCAVE (1978) explicou o processo de afinamento a sotamar pelo transporte mais rápido das frações mais finas ao longo da praia, em relação às mais grossas. GUILLÉN \& JIMÉNEZ (1995) encontraram sedimentos mais grossos em zonas erosivas de barlamar, sugerindo ser produto do intenso joeiramento das frações mais finas e progressivo engrossamento do depósito residual resultante.

Embora o modelo de TAGGART \& SCHWARTZ (1988) seja amplamente aceito na literatura mundial, alguns autores têm encontrado relações diferentes para as duas zonas. MCCAVE (1978) e FRIHY \& DEWIDAR (1993), por exemplo, verificaram haver aumento no tamanho dos grãos na zona de sotamar de praias da Inglaterra e Egito, respectivamente. Atribuiram este processo a um joeiramento progressivo, com remoção das particulas mais finas para o largo e retenção das mesmas em barras submersas. McLAREN (1981) e MCLAREN \& BOWLES (1985) também sugeriram a possibilidade de ocorrência deste tipo de processo nas praias. KRUMBEIN \& GRAYBILL (1965, apud FILKENSTEIN, 1982) e McLEAN \& KIRK (1969, apud FILKENSTEIN, 1982) encontraram sedimentos bem selecionados associados a gradientes elevados em zonas de barlamar e sedimentos pobremente selecionados em perfis suavemente inclinados de sotamar em praias em forma de cabo de guarda-chuva. Problemas também podem surgir nas porções praiais próximas às desembocaduras fluviais e lagunares, as quais estão sob influência concomitante de correntes de deriva litorânea e de correntes fluviais e de maré, que entram e saem do continente. Essas interações alteram o comportamento morfológico e sedimentológico desses locais, podendo ocorrer diminuição do grau de seleção pela inclusão recente de sedimentos continentais, aumento da inclinação e diminuição da largura por migrações da desembocadura etc. Outro caso que complica as interpretações é que alguns perfis praiais podem experimentar mudanças temporárias causadas por 
passagens de frentes frias e/ou marés de sizigia. Se uma berma de tempestade é formada durante estes eventos e depois é erodida pelas ondas durante a quadratura e/ou tempo bom subseqüente, então a praia neste trecho apresentará maior declividade. Esses mecanismos nem sempre podem ser percebidos com facilidade.

Portanto, utilizar apenas os indicadores de TAGGART \& SCHWARTZ (1988) pode levar a falsas interpretações, pois o método não leva em consideração possíveis modificações como as comentadas acima.

TAGGART \& SCHWARTZ (1988) definiram diferenciações de nível de energia das ondas ao longo de uma célula de deriva litorânea, mas não inseriram esse parâmetro em seu método. Neste sentido, a curtose poderia ser um bom indicador dessas variações. Propõe-se, então, uma modificação do método de TAGGART \& SCHWARTZ com a inclusão da curtose como parâmetro de análise.

Antes da utilização deste parâmetro como indicador do nível de energia de ondas nas praias, foram executados testes com amostras de algumas praias ao longo de todo o litoral paulista. Essas praias foram escolhidas por exibirem variações evidentes de energia de ondas ao longo das mesmas. Foram também escolhidas de forma a serem representativas em seu setor morfodinâmico e em relação ao seu estado modal.

O quadro 4 mostra a relação dessas praias, das amostras da antepraia testadas (inverno e verão) e dos seus respectivos valores de curtose. Os pontos de amostragem (perfis) foram previamente separados em função do nível de energia de ondas observado no campo. A localização desses perfis encontra-se nos mapas do Volume II. Amostras de sedimentos próximos a desembocaduras não foram incluidos devido às interferências que podem sofrer, conforme comentado anteriormente. Como as praias dos setores morfodinâmicos I e III são extensas e muito homogêneas em termos de energia de ondas, em geral, as variações observadas foram restritas a uma ou outra estação.

Os dados apresentados no quadro 4 revelam que a curtose mostrou-se um excelente indicador de nivel relativo de energia de ondas na antepraia, com $88 \%$ de resultados positivos. Os $12 \%$ restantes correspondem a resultados obtidos apenas em uma das etapas, mostrando inversões passageiras no sentido das correntes, como mostrado no capitulo VI. 
Quadro 4: Teste da comparação entre a curtose e o nivel de energia nas praias

\begin{tabular}{|c|c|c|c|}
\hline & 6rak & $\begin{array}{l}\text { AREA DE MAIOR ENERGIA } \\
\text { Amostra - classificação (Curtose) }\end{array}$ & $\begin{array}{l}\text { AREA DE MENOR ENERGIA } \\
\text { Amostra - classificaça (Curtose) }\end{array}$ \\
\hline \multirow[t]{2}{*}{ I } & Ilha Comprida & $\begin{array}{l}7 \text { - mesocúrtica }(0,96) \\
431 \text { - platicúrtica }(0,88)\end{array}$ & $\begin{array}{l}14 \text { - mesocúrtica }(1,00) \\
421 \text { - mesocúrtica }(0,91)\end{array}$ \\
\hline & Juréia & 25 - mesocúrtica $(0,97)$ & 26 - leptocúrtica $(1,21)$ \\
\hline \multirow[t]{2}{*}{ II } & Rio Verde & $\begin{array}{l}67 \text { - mesocúrtica }(1,03) \\
525 \text { - mesocúrtica }(0,93)\end{array}$ & $\begin{array}{l}68 \text { - platicúrtica }(0,82) \\
524 \text { - leptocúrtica }(1,47)\end{array}$ \\
\hline & Una & $\begin{array}{l}63 \text { - platicúrtica }(0,89) \\
522 \text { - mesocúrtica }(0,92)\end{array}$ & $\begin{array}{l}65 \text { - leptocúrtica }(1,13) \\
523 \text { - mesocúrtica }(1,00)\end{array}$ \\
\hline \multirow{4}{*}{ IV } & Santos & $\begin{array}{l}82 \text { - mesocúrtica }(1,02) \\
355 \text { - mesocúrtica }(1,03)\end{array}$ & $\begin{array}{l}83 \text { - leptocúrtica }(1,13) \\
356-\text { leptocúrtica }(1,17) \\
\end{array}$ \\
\hline & Guaińba & $\begin{array}{l}85 \text { - leptocúrtica }(1,19) \\
301 \text { - mesocúrtica }(1,06)\end{array}$ & $\begin{array}{l}86 \text { - mesocúrtica }(0,99) \\
302 \text { - leptocúrtica }(1,14)\end{array}$ \\
\hline & Pitangueiras & $\begin{array}{l}92 \text { - platicúrtica }(0,85) \\
308 \text { - mesocúrtica }(1,06)\end{array}$ & $\begin{array}{l}93 \text { - mesocúrtica }(0,91) \\
309 \text { - leptocúrtica }(1,12)\end{array}$ \\
\hline & Enseada & $\begin{array}{l}96 \text { - platicúrtica }(0,85) \\
312 \text { - mesocúrtica }(1,07)\end{array}$ & $\begin{array}{l}97-\text { mesocúrtica }(1,11) \\
313-\text { leptocúrtica }(1,13)\end{array}$ \\
\hline \multirow{3}{*}{$v$} & Boiçucanga & $\begin{array}{l}126 \text { - mesocúrtica }(0,93) \\
453 \text { - platicúrtica }(0,89)\end{array}$ & $\begin{array}{l}124 \text { - mesocúrtica }(1,02) \\
455 \text { - mesocúrtica }(0,96)\end{array}$ \\
\hline & $\begin{array}{c}\text { Santiago e Toque-Toque } \\
\text { Pequeno }\end{array}$ & $\begin{array}{l}120 \text { - mesocúrtica }(0,94) \\
460 \text { - mesocúrtica }(0,97)\end{array}$ & $\begin{array}{l}119 \text { - mesocúrtica }(0,98) \\
459 \text { - platicúrtica }(0,78)\end{array}$ \\
\hline & Guaecá & $\begin{array}{l}117 \text { - mesocúrtica }(1,06) \\
464 \text { - platicúrtica }(0,86)\end{array}$ & $\begin{array}{l}115 \text { - leptocúrtica }(1,41) \\
461 \text { - mesocúrtica }(0,97)\end{array}$ \\
\hline \multirow{6}{*}{ VII } & Caraguatatuba & $\begin{array}{l}156 \text { - mesocúrtica }(0,91) \\
472 \text { - mesocúrtica }(1,04)\end{array}$ & $\begin{array}{l}155 \text { - leptocúrtica }(1.26) \\
471 \text { - leptocúrtica }(1.25)\end{array}$ \\
\hline & Massaguaçu & $\begin{array}{l}159 \text { - mesocúrtica }(1,06) \\
511 \text { - platicúrtica }(0,88)\end{array}$ & $\begin{array}{l}162 \text { - mesocúrtica }(0.95) \\
509 \text { - mesocúrtica }(1.00)\end{array}$ \\
\hline & Maranduba e Lagoinha & $\begin{array}{l}186 \text { - mesocúrtica }(0,95) \\
503 \text { - mesocúrtica }(0,92)\end{array}$ & $\begin{array}{l}184 \text { - mesocúrtica }(0.98) \\
505 \text { - Ieptocúrtica }(1.28)\end{array}$ \\
\hline & Ilamambuca & $\begin{array}{l}175 \text { - platicúrtica }(0,88) \\
483 \text { - mesocúrtica }(0,91)\end{array}$ & $\begin{array}{l}173 \text { - mesocúrtica }(0.91) \\
481 \text { - leptocúrtica }(1.15)\end{array}$ \\
\hline & Félix & $\begin{array}{l}171 \text { - mesocúrtica }(0,99) \\
518 \text { - platicúrtica }(0,87)\end{array}$ & $\begin{array}{l}172 \text { - leptocúrtica }(1.17) \\
519-\text { mesocúrtica }(0.94)\end{array}$ \\
\hline & Ubatumirim & $\begin{array}{l}212 \text { - platicúrtica }(0,83) \\
480-\text { mesocúrtica }(1,03)\end{array}$ & $\begin{array}{l}205 \text { - muito leptocúrtica }(1.67) \\
477 \text { - leptocúrtica }(1.18)\end{array}$ \\
\hline
\end{tabular}


Outro problema enfrentado foi a grande quantidade de dados a serem comparados em cada praia pois, na maioria da vezes, não havia uma única tendência de variação de todos os parâmetros analisados ao longo da mesma. Para resolver essa questão, foi desenvolvido um artifício denominado "matriz de comparação". Cada amostra foi comparada com as duas amostras adjacentes a ela, em relação aos cinco parâmetros analisados: diâmetro médio, desvio padrão/grau de seleção, curtose, inclinação e largura. $\mathrm{Na}$ "matriz de comparação" as amostras foram ordenadas seqüencialmente, conforme sua localização ao longo da praia, sempre de sul para norte. Para cada comparação foram utilizados dois principios básicos: variação do comportamento morfotextural da praia ao longo de uma célula (TAGGART \& SCHWARTZ, 1988), e transferência de sedimentos entre células (CARTER, 1988, p. 205-207). Desta forma admitiu-se que de barlamar para sotamar ocorrem: afinamento dos grãos, aumento do grau de seleção, diminuição do nível de energia, diminuição da inclinação e aumento da largura da praia. O produto de cada comparação foi marcado com um sinal $(+)$ ou $(-)$, respectivamente, se ela indicar zona de sotamar ou de barlamar. Como cada amostra foi comparada com suas duas vizinhas (exceto as amostras das extremidades das praias), então, para cada um dos 5 parâmetros analisados é obtido um par de sinais, que pode ser: $(+/+),(-/-),(+/-)$ ou $(-/+)$. O resultado final da comparação de todos os parâmetros é representado por um outro par de sinais $(+/+,-/-,+/-$ ou $-/+)$, que corresponde à predominância de um ou outro, para cada termo do par.' Assim, se o par final for $(+/+)$, significa que, no local, predomina o processo deposicional, sendo zona de sotamar de uma pequena célula; se for $(-/-)$, predomina a erosão, ou seja, o sedimento encontra-se em zona de barlamar; e, se for $(+/-)$ ou $(-/+)$, representa um zona de transporte (trânsito de sedimentos), havendo ganho e perda de sedimentos. Os rumos de transporte são, então, facilmente deduzidos a partir desses resultados. Em alguns casos o valor do parâmetro mostrou-se igual para as duas amostras comparadas. Quando isto ocorreu recorreu-se aos valores da zona intermarés. persistindo a igualdade, adotou-se o zero (0) como indicativo do termo do par correspondente. Exemplos de "matrizes de comparação" podem ser vistos no capítulo VI, para cada praia.

Dentre os cinco parâmetros analisados, sem dúvida, o mais confiável é o grau de seleção. Pelos resultados obtidos no capítulo $\mathrm{VI}$ pôde-se verificar que o método apresentado é bastante confiável, pois, em geral, as zonas de sotamar corresponderam a pares com sinais positivos para esse parâmetro, enquanto que para as de barlamar os sinais foram negativos. Em alguns casos sinais negativos foram encontrados para zonas 
de sotamar. Eles podem ser explicados pela entrada de sedimentos alóctones ao sistema, através de contribuições de rios ou canais de maré próximos, ou do fundo submarino adjacente. Outro motivo pode estar relacionado aos erros de processamento das amostras (análise granulométrica) ou cálculos estatísticos envolvidos nos métodos utilizados. Por exemplo, em algumas amostras comparadas os valores de desvio padrão mostraram-se muito próximos, com diferenças da ordem de centésimos.

\section{Método de McLAREN}

MCLAREN (1981) apresentou um modelo de interpretação dos rumos de células de deriva litorânea, baseado nas modificações relativas que o diâmetro médio, o desvio padrão e a assimetria sofrem em função de uma determinada área fonte e da atuação de processos sedimentares. O autor usou as relações entre esses parâmetros e não os seus valores absolutos, para determinar as prováveis áreas-fonte $\mathrm{e}$, por conseguinte, os sentidos de transporte costeiro. O termo "fonte" foi usado pelo autor como "proveniência" e inclui a última fonte, que pode ser ou não um outro depósito sedimentar (praia, delta, plataforma continental, rio, etc.). MCLAREN \& BOWLES (1985) aperfeiçoaram este método, incluindo o conceito de função de transferência de energia. Concluíram que, basicamente, dois tipos de processos de transporte podem ocorrer, dando origem a dois casos: Caso B o depósito torna-se mais fino, melhor selecionado e com assimetria mais negativa que a sua fonte $(F / M / N)$, quando houver decréscimo de energia no sentido do transporte, e a função de transferência exibir baixa energia; Caso C - o depósito torna-se mais grosso, melhor selecionado e mais positivo que a sua fonte (G/M/P), para um decréscimo de energia no sentido do transporte, mas transferência inicial de alta energia. KOMAR (1991) explicou este processo através do joeiramento e movimento mais rápido dos grãos mais grossos ao longo da praia (saltação), em relação aos grãos mais finos (suspensão), havendo um atraso destes últimos, tornando-se a fonte mais fina e pior selecionada que o depósito.

MCLAREN (1981) havia se referido a um outro tipo de processo, onde o depósito seria mais fino, melhor selecionado e mais positivo que a fonte (F/M/P), ao qual se deu 0 nome informal de Caso "A". Embora MCLAREN \& BOWLES (1985) tenham concluido que sempre que um sedimento se torna mais fino que a fonte, ele também será sempre mais negativo, os Casos do tipo " $A$ " foram também mostrados nos resultados obtidos (Volume 
II), porém não foram contabilizados como tipos de transporte possiveis. Assim, sua visualização permite a comparação com um tipo de processo que representa uma parcela dos transportes possiveis pelo método de TAGGART \& SCHWARTZ.

MCLAREN \& BOWLES (1985) introduziram ainda o teste do nivel de significância dos resultados obtidos, através do cálculo do Z-estatístico:

$$
Z=\frac{x-N \cdot p}{\sqrt{N} \cdot p \cdot q},
$$

Onde: $\mathrm{x}$ é o número de pares que representam um caso particular de transporte, em uma das duas direções opostas; $\mathrm{N}$ é o número total de pares (combinações possiveis); $p=$ 0,125 e $q=0,875$. O Z-estatístico é considerado válido para $N \geq 30$, ou seja, são necessárias, no mínimo, oito amostras para que as comparações tenham representatividade estatistica. Se $Z>1,645$ o nivel de significância (N.S.) é de 0,05 ; se $Z>$ 2,33 o N.S. é de 0,01 . Apenas estes N.S. são aceitos estatisticamente.

BITTENCOURT et al. (1992) e MUEHE \& CARVALHO (1993) usaram o método de MCLAREN (1981) para caracterizar os sentidos de correntes de deriva litorânea para praias da Bahia e praias e plataforma continental do Rio de Janeiro, respectivamente. Ambos obtiveram correlações positivas em relação a estudos prévios realizados nessas áreas. GIANNINI (1993) usou a forma redefinida do método (McLAREN \& BOWLES, 1985) para praias de Santa Catarina, encontrando resultados similares aos obtidos com outros indicadores.

Neste trabalho, os métodos de TAGGART \& SCHWARTZ-modificado e MCLAREN foram utilizados de maneira complementar. O primeiro permite avaliações ao longo de uma mesma praia e a identificação de pequenas células de transporte, nem sempre perceptiveis em estudos menos detalhados, sendo também muito prático em praias homogêneas, como normalmente são as do tipo dissipativo. Por outro lado, os resultados mostraram que os casos de engrossamento a sotamar também foram encontrados. O método de McLAREN foi usado visando avaliações gerais como as tendências de transferência de sedimentos entre as diferentes praias dentro de um mesmo setor morfodinâmico. Em ambos os métodos foram usadas as amostras da antepraia (intermarés), pelas razões expostas no inicio deste capítulo (deriva praial). 


\section{2. 5. Apresentação dos Dados e Resultados Obtidos}

As tabelas, os gráficos (figuras), os mapas (figuras) e as fotos de campo encontramse no Volume II.

Os quadros estão inseridos neste volume (Volume I), exceto os quadros relativos ao método de MCLAREN (matrizes de correlação), que estão inseridos no Volume II.

O Volume II foi subdividido por setor morfodinâmico, de forma que o leitor pode encontrar agrupados todos os produtos referentes a cada setor. Encontram-se fora desses agrupamentos os anexos pertinentes aos dados e/ou resultados gerais (figuras 1,2 e 93 , e tabela 1). 


\section{CARACTERIZAÇÃO MORFODINÂMICA DA COSTA PAULISTA}

A caracterização do comportamento morfodinâmico das praias do litoral paulista foi apresentada por SOUZA \& SUGUIO (1996a). Como dito anteriormente, os autores se basearam nos trabalhos de SAZAKI (1980, apud CARTER, 1988) (quadro 2), e WRIGHT es al. (1979) e WRIGHT \& SHORT (1984). Entretanto, dada a escassez de dados sobre clima de ondas, não foi possivel utilizar o índice morfométrico denominado parâmetro de medida de surfe (surf scaling parameter) $\varepsilon$, usado por esses autores na determinação dos estados morfodinâmicos. Por outro lado, os demais dados foram suficientes para estabelecer a classificação adotada.

SOUZA \& SUGUIO (1996a) subdividiram o litoral de São Paulo em sete setores morfodinâmicos (figura 2), que foram o ponto de partida para a apresentação dos resultados obtidos neste trabalho.

Os comentários sobre a presença e tipologia de barras submersas foram fundamentadas em observações de campo e de fotos aéreas, e em dados fornecidos pelo $18^{\circ}$ Grupamento de Bombeiros do Estado de São Paulo, que trabalha com o salvamento nas praias. Foi elaborado um questionário contendo uma série de perguntas a respeito das praias, que foi respondido pelos guarda-vidas responsáveis por cada Posto de Salvamento existente no litoral paulista.

Os dados referentes ao comportamento morfológico e textural das praias encontram-se em gráficos (figuras) exibidos no Volume $\|$.

Os dados de ondas (tipo de arrebentação e número de quebras), apresentados a seguir, correspondem a observações visuais feitas nos trabalhos de campo.

Existem quatro tipos básicos de quebra de ondas. Não há um consenso, na literatura nacional, em relação à tradução dos termos usados em inglês. Nesta pesquisa adotou-se as traduções usadas em TOLDO Jr. et al. (1993): arrebentação deslizante (spilling); arrebentação mergulhante (plunging); arrebentação ascendente (surging); e arrebentação frontal (collapsing). 


\section{1. SETOR MORFODINÂMICO I}

No extremo sul do Estado, entre Ilha Comprida (municipio de llha Comprida) e a Praia da Juréia (municipio de Peruíbe) e estendendo-se segundo a direção NE-SW (tabela 1), desenvolve-se um ambiente de ilha-barreira (MARTIN \& SUGUIO, 1978) que abriga um sistema lagunar-estuarino complexo sob influência do Rio Ribeira de Iguape. Neste contexto estão as praias de llha Comprida, Leste e Juréia. A Praia de llha Comprida é a maior do Estado, com cerca de $70 \mathrm{~km}$ de extensão.

O setor I caracteriza-se pela presença, junto à linha de costa, de dunas frontais inativas de pequeno porte. $\mathrm{Na}$ ltha Comprida as dunas inativas atingem alturas máximas de $12 \mathrm{~m}$, sendo as únicas bem preservadas do litoral paulista (foto 1). Elas capeiam terraços holocênicos alçados de 1,5 a $3 \mathrm{~m}$. Pequenos depósitos eólicos atuais muito instáveis, também fazem parte da paisagem da zona de pós-praia nas praias do Leste, Juréia e nas extremidades da liha Comprida.

A ocupação urbana mais densa encontra-se apenas no setor norte da llha Comprida, onde não há falésias nos terraços marinhos. No restante, a ocupação é rarefeita sobre os depósitos marinhos antigos e dunas, com boa preservação dos mesmos. Na Praia do Leste não existe ocupação, pois ela é completamente inundada pelas preamares de sizígia. Na Praia da Juréia o crescimento urbano tem sido cada vez maior nos últimos anos, com ocupação intensa das áreas marginais à praia e, até mesmo, da zona inferior da pós-praia. Isso ocorre principalmente nos extremos sul e norte dessa praia, onde as falésias nas cristas praiais holocênicas são muito baixas. No extremo sul da Juréia a ocupação atinge as áreas de risco sujeitas à intensa dinâmica do Rio Ribeira de Iguape. No extremo norte a urbanização ocorre sobre a plana e vasta área de areias eólicas da póspraia, à frente de um pacote de dunas e terraços elevados de até $13 \mathrm{~m}$. Na porção central dessa praia a ocupação é bem menos intensa, dada a presença de um grande campo de dunas e terraços escarpados de até $3 \mathrm{~m}$ de altura junto à praia (foto 2 ). Nesse trecho a praia é bem estreita e sujeita à inundação durante as preamares de sizígia.

As praias do setor I são do tipo dissipativo de alta energia (fotos 1 e 2). As praias e zonas de surfe são largas e com baixas inclinações, em geral, $\leq 3^{\circ}$ na antepraia (média de $2^{\circ}$ ) e $\leq 1,5^{\circ}$ na zona superior de surfe ou face litorânea. As bermas não estão presentes ou são muito incipientes, sendo os perfis praiais muito homogêneos e planos. As areias são 
predominantemente finas a muito finas, muito bem selecionadas, simétricas e mesocúrticas. O tipo de quebra de ondas é deslizante, geralmente em número $\geq 4$. Ocorrem amplas barras de deriva litorânea e feições associadas a correntes de retorno.

\section{2. SETOR MORFODINÂMICO ॥}

Este setor reúne as praias do Rio Verde (municipio de Iguape), Una (Iguape/Peruibe) e Guaraú (Peruíbe). São praias menores, encerradas entre os costões rochosos de embasamento précambriano da Serra da Juréia à Serra de Peruíbe, estando a Praia do Una interrompida pelo rio de mesmo nome. Encontra-se aí a Estação Ecológica da Juréia, área de Preservação Ambiental do Parque Estadual da Serra do Mar. As praias do Rio Verde e Una, ao sul do Rio Una, são praticamente intocadas pelo homem. Possuem orientação geral de WSW-ENE (tabela 1). A ocupação urbana ocorre nas praias do UnaNorte (margem esquerda do Rio Una) e do Guaraú, sendo intensa nesta última.

A presença de falésias em terraços marinhos holocênicos e dunas inativas, junto à linha de costa, é localizada e sempre associada à Praia do Una, nas proximidades do Rio Una (foto 3). Da mesma forma, retrabalhamentos eólicos atuais, embora fracos, são observados somente aí, principalmente na Praia do Una-Sul (margem direita o Rio Una). Nesse local a costa é mais aberta e há intensa deposição associada às correntes de deriva litorânea e aos fluxos fluvial e de maré.

Neste setor predominam areias finas, muito bem selecionadas, mesocúrticas e com assimetrias variando entre valores positivos e negativos. As inclinações médias variam entre $3,7^{\circ}$ para a antepraia e $4,7^{\circ}$ para a face litorânea. No entanto, algumas variações nas características das praias são observadas em relação ao sul e ao norte do Rio Una.

As praias ao sul do Rio Una (porção central e sul da Praia do Una e Praia do Rio Verde) são, em geral, estreitas e constituídas de areias médias e finas, muito bem a bem selecionadas. Apresentam inclinações moderadas a altas $\left(3-10^{\circ}\right)$, com médias de $5,8^{\circ}$ para a antepraia e face litorânea (foto 4). Bermas praiais aparecem nas praias do UnamSul (porções central e sui) e Rio Verde. As quebras de ondas, em geral de 2 a 3, são do tipo mergulhante, podendo ocorrer localmente o tipo ascendente. Essas praias são 
predominantemente do tipo intermediário, mas em ambas há locais com características reflexivas (foto 4 ).

A praia ao norte do Rio Una (margem esquerda) e a Praia do Guaraú (foto 5), embora também confinadas, apresentam-se mais largas, com perfis suaves (média na antepraia é de $1,1^{\circ}$ e na zona de surfe superior é de $1,8^{\circ}$ ) e constituídas de areias finas (foto 5). As quebras de ondas são do tipo deslizante e em número próximo de 5 . Essas praias são do tipo dissipativo, respectivamente, de alta e baixa energia.

Portanto, no setor II, as praias variam de intermediárias ao sul para dissipativas ao norte.

\section{3. SETOR MORFODINÂMICO III}

Este setor compreende as praias de Peruíbe, Itanhaém e Praia Grande, pertencentes aos municípios homônimos. Corresponde a um corredor de direção NE-SW (tabela 1) com cerca de $70 \mathrm{~km}$ de praias homogêneas, praticamente contínuas, largas e planas. Esta costa diferencia-se do setor I pela presença de uma vasta e quase contínua planicie costeira de cristas praiais, onde predominam depósitos marinhos pleistocênicos e dunas. A inexpressividade de ocorrência de terraços marinhos elevados e dunas junto à praia também é uma característica marcante nesse setor (foto 6), sendo a faixa de depósitos marinhos holocênicos restrita e frontal à praia. Os ecossistemas são influenciados por rios de porte médio, sendo o Rio Itanhaém o maior da região. Em Peruíbe é importante o Rio Preto. Entre Itanhaém e Praia Grande encontra-se o Rio Mongaguá. Há densa ocupação e urbanização da linha de costa (foto 7), exceto no trecho ao norte da Praia de Peruíbe, onde há uma mineração de areias pleistocênicas. Retrabalhamentos eólicos atuais das areias praiais podem ser observados principalmente ao sul de Peruibe.

As praias são constituídas de areias finas, muito bem selecionadas, predominantemente simétricas e mesocúrticas. As quebras de ondas são do tipo deslizante-mergulhante, em geral em número de 4 . As inclinações médias medidas na antepraia e face litorânea são de $2^{\circ}$, mas podem atingir até $4^{\circ} \mathrm{em}$ alguns locais. Pequenas cúspides praiais (foto 6) são freqüentemente encontradas nessas praias. Bermas estão 
ausentes ou são muito incipientes, e ocorrem duas a três barras de deriva litorânea paralelas e geraimente contínuas.

As praias do setor III têm estado modal dissipativo de alta energia mas localmente, podem ocorrer estados intermediários.

\section{V.4. SETOR MORFODINÂMICO IV}

Este setor está provavelmente inserido em um bloco tectônico (Bloco de Santos), abatido em relação às faixas costeiras adjacentes, caracterizado pela presença de morros pouco elevados (150-300 $\mathrm{m}$ ) adentrando o oceano e pelo desenvolvimento de um sistema estuarino (Estuário de Santos). Ocorrem duas grandes ilhas arenosas interiores resultantes desse sistema (São Vicente e Santo Amaro), nas quais afloram predominantemente depósitos marinhos de idade holocênica. Os terraços marinhos pleistocênicos encontramse restritos à região de São Vicente, portanto ao sul do setor.

A região engloba os municipios de São Vicente, Santos e Guarujá, sendo também a de maior desenvolvimento econômico do litoral paulista, portanto sujeita à grande pressão imobiliária e muito densa ocupação da orla.

As maiores praias que bordejam o estuário santista são basicamente de dois tipos: as muito abrigadas, de fundo de baía, como em Santos e São Vicente, com direções E-W (tabela 1); e as praias de enseadas, mais abertas, como no Guarujá, orientadas segundo NE-SW e E-W (tabela 1). Praias menores, em arco, com direções N-S e NE-SW, desenvolvidas nas reentrâncias rochosas frontais da llha de Santo Amaro (Guarujá), também fazem parte da paisagem local. Não ocorrem, junto à linha de costa, terraços marinhos holocênicos e/ou dunas. Dunas embrionárias podem ser vistas na porção central da Praia da Enseada (Guarujá). Esse é o trecho mais aberto da praia, e também o de maior disponibilidade de sedimentos. Segundo HIDROCONSULT (1974/1975) as correntes que atuam no largo, ao sul dessa área, chegam diretamente nesse trecho da praia e, provavelmente, trazem grande volume de material para ela. Além disso, as intervenções antrópicas são pequenas. 
Nas praias do setor IV predominam areias finas, muito bem selecionadas, simétricas e mesocúrticas. As inclinações médias obtidas para a antepraia são de $2,6^{\circ}$, e para a zona de surfe superior são de $3,3^{\circ}$. No entanto, essas características variam em função da localização e posição espacial das praias.

As praias da Baía de Santos, como São Vicente, Itararé e Santos, são dissipativas de baixa energia (fotos $8 \mathrm{a}$ e $8 \mathrm{~b}$ ). Apresentam perfis muito planos e homogêneos, com antepraias e zonas de surfe largas e inclinações médias da ordem de $1,4^{\circ}$ e $2^{\circ}$, respectivamente. São constituídas de areias finas a muito finas. As quebras são do tipo deslizante e em número igual ou superior a 3 , com muito baixa energia. Uma barra de deriva litorânea descontínua pode ocorrer na Praia do Itararé, em São Vicente, a qual é também a menos abrigada da Baía de Santos. Estas praias são as mais impactadas pelas atividades antrópicas (fotos $8 \mathrm{a}, 8 \mathrm{~b}$ e $8 \mathrm{c}$ ).

As praias ao fundo das enseadas como, por exemplo, Astúrias, Pitangueiras, Enseada, Pernambuco e Perequê, são intermediárias a dissipativas de alta energia, com regimes de ondas mais enérgicas (foto 9). As praias são largas, com areias finas a moderadas, e inclinações médias (na antepraia e face litorânea) entre 2 e $4^{\circ}$. As quebras são do tipo deslizante-mergulhante, em número de 2 a 4 . Barras de deriva litorânea interrompidas (foto 9) e em forma de crescente geralmente estão presentes. As bermas são incipientes.

As praias de bolso como, por exemplo, Capitão, Guaiúba, Tombo e São Pedro, são do tipo intermediário e reflexivo, com areias médias a grossas e inclinações mais comuns entre 3,5 e $6^{\circ}$, estando as médias obtidas para a antepraia entre 2 e $4,5^{\circ}$, e para a face litorânea entre 1,5 e $4,4^{\circ}$ (foto 10 ). Os perfis são transicionais a ingremes, e apresentam bermas praiais geralmente bem desenvolvidas. Cúspides praiais em geral associadas a grandes embaiamentos também ocorrem (foto 10). As quebras (1 a 2) são do tipo mergulhante-ascendente, às vezes também frontal. 


\section{5. SETOR MORFODINÂMICO V}

Deste setor, em direção ao norte do Estado, a costa fica mais heterogênea, ou melhor, mudam suas características muito mais freqüentemente e a distâncias bem menores que no litoral ao sul da Baia de Santos. Isto ocorre devido ao maior recorte da costa pela proximidade da Serra do Mar com o oceano. Neste setor estão os municípios de Bertioga e grande parte de São Sebastião.

No setor $\mathrm{V}$ a planície costeira de cristas praiais retoma sua relativa continüidade, embora com dimensões menores que as do setor III, mas apresentando uma inversão em relação à área de ocorrência dos depósitos, pois aqui predominam os holocênicos, estando os pleistocênicos mais restritos à região de Bertioga. A ocorrência de falésias em terraços marinhos holocênicos junto à linha de costa é localizada, mas bem marcada, como na desembocadura do Rio Itaguaré (vide capitulo VII) e na Praia de Guaratuba. Pequenas dunas inativas também ocorrem nesse setor, embora pouco preservadas.

Ao norte do Canal da Bertioga as praias gradam de uma orientação inicialmente ENE-WSW, entre Bertioga e Boracéia, para E-W, entre Boracéia e Maresias, até atingirem a direção NW-SE nas proximidades do Canal de São Sebastião (praias entre a do Paúba a de Barequeçaba). De modo geral, a extensão e a largura das praias diminuem, enquanto as declividades e a granulometria das mesmas aumentam no sentido das praias de orientação E-W. Da mesma, forma aumenta a refletividade das praias nesse sentido. Isto ocorre porque as ondas de SE chegam em major ângulo com relação a essas praias e a linha de costa torna-se mais recortada.

De maneira geral, no setor $V$ predominam areias muito finas a finas, muito bem selecionadas, com distribuições simétricas e mesocúrticas. As inclinações médias obtidas para a antepraia e zona de surfe superior são, respectivamente, $3^{\circ}$ e $4,2^{\circ}$.

As praias orientadas segundo a direção ENE-WSW são as mais longas e largas desse setor (foto 11). São constituídas de areias finas e muito bem selecionadas e possuem inclinações entre 1 e $4^{\circ}, \mathrm{com}$ médias para a antepraia e a face litorânea respectivamente, de $1,6^{\circ}$ e $2,2^{\circ}$. As zonas de surfe são largas e os perfis praiais são planos a transicionais, levemente inclinados. As quebras são do tipo deslizante-mergulhante, em 
número $\leq 4$. Essas praias apresentam várias barras de deriva litorânea paralelas e continuas. São, portanto, do tipo dissipativo de alta energia a localmente intermediário.

As praias de direção E-W são, em geral, pouco extensas e estreitas, apresentando inclinações elevadas de $3,5^{\circ}$ até $15^{\circ}$, sendo as médias da antepraia de $3,9^{\circ}$, e da face litorânea de $4,5^{\circ}$. Predominam areias médias a grossas e perfis praiais em degraus. A maioria das praias é intermediária, mas entre elas ocorrem também as predominantemente reflexivas (Camburizinho e Boiçucanga). As bermas e cúspides praiais bem desenvolvidas estão presentes. Nas praias intermediárias as bermas são baixas e ocorrem cúspides associadas a barras interrompidas em forma de crescente, correntes de retorno e embaiamentos na praia (foto 12). Nas reflexivas as bermas são altas (foto 13) e não ocorrem barras. São mais freqüentes as quebras do tipo mergulhante (1-2), podendo ocorrer as ascendentes/frontais.

As praias de direção NW-SE são mais reflexivas na porção sul do trecho em que ocorrem, e dissipativas de baixa energia na porção norte (foto 14). As primeiras têm elevadas inclinações, em média de $5^{\circ}$ na antepraia e $9^{\circ}$ na face praial superior. As areias são grossas a muito grossas, e as bermas e cúspides praiais bem desenvolvidas. $O$ número de quebras é 1 , do tipo ascendente/frontal. As dissipativas são muito planas e compostas de areias muito finas e micáceas, não apresentam barras e as ondas (1 quebra) são do tipo deslizante de baixa energia.

\section{6. SETOR MORFODINÂMICO VI}

Este compartimento possui praias com caracteristicas peculiares, pois estão confinadas no interior do Canal de São Sebastião. Nele estão o núcleo urbano de São Sebastião e o município de Ilha Bela (Ilha de São Sebastião).

As praias são, em geral, de pequenas dimensões e a maioria das praias do interior do canal não apresenta estados modais característicos, pois os perfis emersos são similares aos estados intermediários e reflexivos e os submersos podem ser semelhantes a perfis dissipativos de baixa energia e reflexivos (fotos 15 e 16). Essas variações são devidas ao confinamento dessas praias atrás da llha de São Sebastião. As ondas que as 
atingem são produto de interferências (difração e reflexão) sofridas ao redor da llha, ou influenciadas por ventos locais que atuam no interior do Canal.

A Praia das Cigarras, no extremo norte do lado continental do canal, tem orientação $\mathrm{N}-\mathrm{S}$ e características reflexivas a intermediárias. No outro extremo, encontra-se a Praia do Balneário, que apresenta perfil dissipativo de baixa energia. Estas são as praias mais abertas desse setor e, por isso, estão mais sujeitas à influência das ondas de mar aberto.

Nas praias do setor $\mathrm{VI}$ predominam areias médias e finas, moderadamente selecionadas, mesocúrticas e com distribuições heterogêneas de assimetrias. As inclinações médias obtidas para as praias do lado continental são: $5,2^{\circ}$ para a antepraia e $4,2^{\circ}$ para a face litorânea. Nas praias do lado insular os valores obtidos foram de $3,9^{\circ} \mathrm{e}$ $6,3^{\circ}$, respectivamente para a antepraia e a face litorânea (foto 16). As praias do lado externo da liha de São Sebastião não foram incluídas neste estudo devido às dificuldades e até impossibilidade de acesso a elas.

\section{7. SETOR MORFODINÂMICO VII}

O trecho entre o sul de Caraguatatuba e o extremo norte do Estado de São Paulo apresenta-se muito recortado, em virtude da grande proximidade da Serra do Mar com a linha de costa. Neste setor estão os municipios de Caraguatatuba e Ubatuba.

Assim como as planícies costeiras, as praias são pequenas, excetuando-se a de Caraguatatuba. Praticamente não ocorrem falésias em terraços marinhos junto à linha de costa, que são vistos apenas nas praias de Massaguaçu, Tabatinga, Caçandoca e mais claramente na Praia Vermelha do Norte. As dunas inativas não estão presentes nesse setor, pois não encontraram condições propícias ao seu desenvolvimento. Retrabalhamentos eólicos incipientes são raramente observados.

A irregularidade dessa linha de costa determinou o desenvolvimento de praias abrigadas ao fundo de amplas enseadas (Caraguatatuba) e pequenas baías (Mar Virado, Fortaleza, Flamengo, Ubatuba, Ubatumirim e Picinguaba) ou de praias abertas expostas frontalmente aos sistemas de ondas de SE (porção norte de Ubatuba). Em Caraguatatuba a orientação das praias é N-S (tabela 1), depois passa a NE-SW até o sul de Ubatuba, 
retomando novamente a direção $\cong \mathrm{N}-\mathrm{S}$ junto ao núcleo urbano dessa cidade. A partir de Ubatuba as praias reassumem a orientação NE-SW e, no extremo norte deste município infletem para NW-SE.

No setor VII as praias variam muito suas características, com areias finas a grossas, predominando as moderadamente selecionadas, simétricas e mesocúrticas. Os valores médios de inclinação obtidos para a antepraia e zona de surfe superior são de, respectivamente, $4,5^{\circ}$ e $6^{\circ}$.

As praias com orientação NE-SW (predominante no setor) variam, em geral, do estado reflexivo a intermediário no mesmo arco praial (foto 17). As areias são médias a muito grossas, as bermas são altas e as cúspides geralmente ocorrem; as inclinações variam de 6 a $15^{\circ}$ (figura 18) e as quebras são ascendentes/frontais, em número de 1-2, localmente mergulhantes. Na extremidade sul da Praia de Massaguaçu (foto 18) ocorrem os perfis mais inclinados já medidos em todo o litoral paulista, com ângulos de até $30^{\circ}$ (SOUZA, 1990).

As praias N-S também mudam seu estado ao longo de seu arco, sendo dissipativas de baixa energia a intermediárias (Perequê-Açu, Caraguatatuba) ou reflexivas (Itaguá, Iperoig, Barra-Seca). As inclinações médias na antepraia e face litorânea são de, respectivamente, $5,1^{\circ}$ e $5,4^{\circ}$, podendo variar entre $1^{\circ}$ e $13^{\circ}$ (fotos $19 a$ ). Em geral, a morfologia praial se modifica devido a estados predominantemente erosivos (foto 19b). As areias variam, predominantemente, de médias a grossas e muito finas, moderadamente a muito bem selecionadas, e as quebras, com número de $1-4$, podendo ser mergulhantes a deslizantes. Cúspides, bermas e barras de deriva litorânea interrompidas podem estar presentes nos perfis intermediários. No extremo sul da linha de costa de Caraguatatuba desenvolve-se uma planície de maré arenosa (SOUZA \& FURTADO, 1987) que tem, portanto, caracteristicas extremamente dissipativas (foto 20), sendo o único exemplo de planicie de maré de linha de costa do litoral paulista (SOUZA, 1995b).

As praias de direção NW-SE como Dura, Enseada, Ubatumirim, Almada e Fazenda, são dissipativas de baixa e 'média energia. Os perfis são planos e de areias finas a muito finas, muito bem a bem selecionadas (foto 21). As quebras, em número $\geq 4$, são do tipo deslizante, podendo não haver quebras em trechos muito abrigados. Cúspides mal desenvolvidas podem ocorrer em locais com erosão (foto 21). 


\section{AS CÉLULAS DE DERIVA LITORÂNEA NAS PRAIAS PAULISTAS E O TRANSPORTE COSTEIRO}

Como foi apresentado no capítulo IV, as identificações das células de transporte costeiro ou deriva litorânea nas praias paulistas foram baseadas em três principais métodos:

(a) Análise de produtos de Sensoriamento Remoto;

(b) Método de TAGGART \& SCHWARTZ -modificado;

(c) Método de MCLAREN.

Incluem-se, nos dois primeiros itens, os resultados obtidos com as medições de ondas nas fotos aéreas e no campo. As tabelas de números 2 a 14, exibidas no Volume II, mostram esses resultados.

A caracterização morfotextural das praias do litoral paulista foi executada a partir do levantamento de 348 perfis de amostragem, distribuídos entre as 64 praias mais importantes, e da análise de cerca de 1050 amostras. Na tabela 1 (Volume II) encontramse a relação de todos os perfis levantados e a orientação espacial da praia em cada perfil, o comprimento aproximado da praia, e as condições de maré e de tempo vigentes durante os trabalhos de campo. A localização desses perfis, bem como de todos os pontos de controle, estão nos mapas (figuras $4,5,11,12,18,19,25,26,37,38,52,53,57,58$, e 81 a 86) que se encontram no Volume II. Nesses mapas é também possível observar algumas características relevantes como: urbanização da orla, presença de obras de engenharia perpendiculares e paralelas à linha de costa (enrocamentos, espigões, emissários com espigão emerso, arrimos em pedra, etc.), plataformas de abrasão marinha e presença de falésias em terraços marinhos e dunas.

Os gráficos de variaçāo dos parâmetros texturais (diâmetro médio, desvio padrão, assimetria e curtose) e morfológicos (largura e inclinação praial) de cada praia são exibidos no Volume 11. Para cada parâmetro foram apresentados os dados relativos ao inverno e ao verão. Nesses gráficos o eixo das abcissas contém os perfis praiais dispostos sempre de sul para norte, em relação ao alinhamento da costa paulista. 
Os comentários feitos sobre as características texturais dos sedimentos foram baseados nos gráficos apresentados, em relação aos dados das três zonas amostradas (pós-praia ou supramaré, antepraia ou intermarés, face litorânea superior ou inframaré), essencialmente em relação ao diâmetro médio e desvio padrão. Nas "matrizes de comparação" (inseridas no Volume 1) do método de TAGGART \& SCHWARTZ-modificado foram usados o diâmetro médio, o desvio padrão, a curtose e os parâmetros morfológicos. A assimetria foi utilizada apenas na elaboração das matrizes do método de McLAREN (quadros $8,9,14,15,20,21,31,32,45,46,60$ e 61 inseridos no Volume II). Nesses dois métodos as amostras comparadas pertencem à antepraia.

\section{1. SETOR MORFODINÂMICO I}

Neste Setor foram estudadas as praias de liha Comprida, Leste e Juréia.

\section{1. 1. Análise de Produtos de Sensoriamento Remoto}

Foram analisadas fotografias aéreas de 1962 (incompleto), 1966, 1973/1974 e 1981 (quadro 3).

A figura 4 mostra os resultados obtidos com a fotointerpretação para este setor. As medidas de ortogonais ondas feitas nessas fotografias, bem como os rumos prováveis das correntes de deriva litorânea são encontrados na tabela 2.

De modo geral, os resultados sugerem tendências regionais de transporte para SW, com algumas variações de sentido oposto, principalmente ao longo da Praia de Ilha Comprida. Nas imagens de satélite de 1976 e da década de 90 há predominância de transporte NE, com pequenas inversões ao longo da llha Comprida, porém na Praia da Juréia a orientação geral é para SW.

Ao longo da liha Comprida são importantes algumas observações, como as que se seguem.

(a) Nas desembocaduras lagunares de Cananéia e lcapara ocorrem intensos processos deposicionais associados à convergência de transportes costeiros e flúvio-lagunares; 
(b) Dunas inativas (vegetadas) elevadas ocorrem ao longo de grande parte da llha, desde o sul até a porção central-norte, desaparecendo no extremo norte, onde dão lugar a pequenas dunas embrionárias atuais;

(c) Correntes de retorno concentradas (grandes giros) associadas a plumas de material em suspensão são observadas nas partes sul e central-norte da praia, sugerindo tratarem-se de centros de convergência de correntes de deriva litorânea;

(d) Embaiamentos na praia ocorrem associados às células de correntes de retorno;

(e) A extensão da pluma da porção norte-central, medida nas fotos aéreas e nas imagens de satélite, é de cerca de $3,4 \mathrm{~km}$ mar adentro ( $\cong$ isóbata de $14 \mathrm{~m}$ na Carta Náutica da D.H.N. $n^{0} 1700$, de 1994);

(f) No trecho sul-central da praia (aproximadamente entre os pontos 529 e 532A) há forte estreitamento na largura da mesma, com erosão dos depósitos marinhos e das dunas holocênicas;

(g) As desembocaduras dos córregos Barra Nova e Barra Velha são fortemente deslocadas para norte, sugerindo derivas locais nesse sentido.

TESSLER (1988) sugeriu a possivel existência da corrente de retorno ao centralnorte da praia llha Comprida, quando observou a pluma de sedimentos em suspensão na imagem de satélite de 1976.

Nas praias do Leste e Juréia foram observadas pequenas células de deriva litorânea de sentidos opostos. Na Juréia, um forte estreitamento da praia ocorre ao norte, com erosão dos depósitos marinhos e das dunas holocênicas.

\section{1. 2. MÉTODO DE TAGGART \& SCHWARTZ-MODIFICADO}

A figura 5 mostra os resultados obtidos para o setor 1, e a tabela 3 os dados relativos às medições das ortogonais de ondas feitas no campo, bem como os prováveis rumos das derivas litorâneas. As condições meteorológicas e a fase astronômica de maré reinantes durante as duas etapas estão na tabela 1.

As figuras 6 e 7 mostram o comportamento da largura e da inclinação ao longo das praias desse setor. 


\section{- Ilha Comprida}

Esta praia é a mais longa de todo o litoral, e também a mais larga do setor 1 . Embora ocorram variações de largura ao longo dela, há tendência geral de alargamento de sul para norte. As grandes diferenças de largura observadas no perfil $3 / 434$, entre o inverno e verão, estão associadas a modificações na sedimentação. Nesse local há uma ampla feição deposicional, em forma de cúspide, conhecida por Pontal e produzida pela convergência de correntes de deriva litorânea e os fluxos de vazante da desembocadura lagunar de Cananéia. Durante as preamares de sizígia, como ocorreu no verão, a cúspide fica totalmente submersa. Além disso, ela também pode migrar para sul, como observado no verão, o que evidencia uma forte corrente nesse sentido. Uma diferença acentuada na largura da praia foi identificada no trecho entre os perfis $7 / 431$ e $10 / 417$, onde ocorre forte estreitamento da praia, com falésias em depósitos marinhos e dunares holocênicos.

Outro aspecto morfológico interessante, também observado nas fotos aéreas, é a ocorrência de grandes embaiamentos ao longo da praia, como ao sul (entre os pontos $4 / 433$ e 5/432), ao centro-norte (associado à grande célula de correntes de retorno) e ao norte (entre os pontos 15/536-A e 536-B). DOLAN et al. (1974, apud KOMAR, 1995) também encontraram grandes embaiamentos em ilhas-barreiras da costa dos Estados Unidos, associados à erosão por correntes de retorno concentradas.

Os perfis de inverno mostraram-se mais inclinados e mais estreitos que os de verão. As maiores inclinações praiais foram encontradas no trecho entre os perfis $7 / 431$ e 10/417, com valores de até $4^{\circ}$ para a antepraia e $6^{\circ}$ para a pós-praia. Nos perfis adjacentes a este trecho as diminuições na inclinação compreendem intervalos de até $3^{\circ}$. As mais baixas inclinações praiais ocorrem na porção norte da llha, medidas nos pontos $14 / 421$ e 16/422 $\left(1-1,5^{\circ}\right)$. Entre esses dois pontos, entretanto, há um trecho com intenso processo erosivo (pontos 15/536A a 536B), onde as inclinações aumentam e a largura diminui, e várias casas foram destruidas pela ação marinha (vide capitulo VII). Nesse local não foram levantados perfis de amostragem porque, no inverno, havia restos de algumas casas até a porção inferior da antepraia (foto 22 ).

O comportamento textural dos sedimentos variou ligeiramente, ao longo da praia, nas duas etapas (figura 8 ). Predominaram areias finas $(87,3 \%$ ), com poucas areias muito finas $(12,7 \%)$, altos graus de seleção, distribuidos entre termos muito bem selecionados $(74,6 \%)$ e bem selecionados $(22,2 \%)$. De maneira geral, duas grandes tendências foram 
observadas: no inverno houve ligeira diminuição no tamanho do grãos e aumento do grau de seleção de sul (SW) para norte (NE), com ocorrência de areias mais finas nos perfis 13 , 14 e 16; no verão constatou-se uma tendência inversa, com os termos mais finos nos perfis ao sul (pontos 433 e 434).

BARCELOS (1975) e TESSLER (1988) obtiveram resultados similares em relação aos aspectos texturais, porém identificaram somente diminuição no tamanho do grãos e aumento do grau de seleção de SW para NE, sugerindo atuação de correntes de deriva litorânea nesse sentido. Entretanto, esses autores não demonstraram preocupação em relação à época de amostragem, que foi feita apenas uma vez, em período não esclarecido nos respectivos textos.

No entanto, para uma praia com $70 \mathrm{~km}$ de extensão, pode-se supor que células menores também ocorram, como mostram os resultados obtidos a partir da aplicação do método de TAGGART \& SCHWARTZ-modificado.

A "matriz de comparação" obtida para a Ilha Comprida (quadro 5) revela algumas tendências mais importantes.

(a) A porção central da Praia da liha Comprida (perfis 7/431 e 10/417) mostrou-se predominantemente erosiva, sugerindo ser zona de barlamar de duas células de deriva litorânea, com centro de divergência que pode migrar para o norte ou para o sul ao longo deste trecho;

(b) Entre os pontos $11 / 418$ e $13 / 420$ ficou bem caracterizada uma extensa zona de transporte;

(c) Verificou-se uma inversão de processos no setor sul da praia, entre os pontos 5/432, $4 / 433$ e $3 / 434$, talvez pela atuação de pequenas células de deriva litorânea, com migrações das zonas de barlamar ao longo deste trecho;

(d) Nos pontos $14 / 421$ e $16 / 422$ os processos sedimentares sugeridos foram iguais nas duas etapas sendo, respectivamente, deposicional e erosivo.

Esses resultados são bastante semelhantes aos obtidos pela interpretação de produtos de sensoriamento remoto, como pode ser visto pela comparação entre os mapas das figuras 4 e 5 .

As correntes de retorno concentradas no setor centro-norte da praia, tão fortemente evidenciadas nas fotografias aéreas e nas imagens de satélite, por outro lado, não 
puderam ser reconhecidas no campo, exceto pelos grandes embaiamentos observados no campo. A identificação dessas células a partir das variações morfológicas e texturais da praia, não é tarefa fácil, principaimente se forem tão amplas como as que ocorrem nesse trecho da liha Comprida. Além disso, a sua atuação pode ser heterogênea ao longo do ano ou pode haver migração do canal de retorno, mascarando as respostas na morfologia e na textura da praia. Não obstante, embora variações morfológicas expressivas não tenham sido identificadas no campo, uma amostragem mais detalhada poderia evidenciar variações texturais. E importante frisar que apesar de os produtos de sensoriamento remoto analisados terem sido obtidos predominantemente nos meses de inverno e sob condições de tempo bom, pôde-se constatar deslocamentos da célula de retorno citada.

Quadro 5: Matriz de comparação elaborada para a Praia de Ilha Comprida

\begin{tabular}{|c|c|c|c|c|c|c|c|c|c|}
\hline \multirow{2}{*}{\begin{tabular}{|l} 
Etapa \\
de \\
Amost
\end{tabular}} & \multirow[b]{2}{*}{$\begin{array}{l}\text { Perfil } \\
\text { Praial }\end{array}$} & \multicolumn{3}{|c|}{ PARÁM. TEXTURAIS } & \multicolumn{2}{|c|}{ MORFOLOGIA } & \multirow[b]{2}{*}{$\begin{array}{c}\text { Resultado } \\
\text { Final }\end{array}$} & \multirow[b]{2}{*}{$\begin{array}{c}\text { PROCESSO } \\
\text { E=erosão } \\
D=\text { deposição } \\
T=\text { transporte }\end{array}$} & \multirow[b]{2}{*}{$\begin{array}{c}\text { SENTIDO } \\
\text { DA } \\
\text { DERIVA }\end{array}$} \\
\hline & & $\begin{array}{l}\text { Diâmetro } \\
\text { Médio }\end{array}$ & $\begin{array}{c}\text { Grau } \\
\text { de } \\
\text { Seleção }\end{array}$ & $\begin{array}{l}\text { Curto- } \\
\text { se }\end{array}$ & $\begin{array}{l}\text { Incli- } \\
\text { nação }\end{array}$ & $\begin{array}{l}\text { Largu- } \\
\text { ra }\end{array}$ & & & \\
\hline \multirow{11}{*}{$\begin{array}{l}\mathrm{I} \\
\mathrm{N} \\
\mathrm{V} \\
\mathrm{E} \\
\mathrm{R} \\
\mathrm{N} \\
\mathrm{O}\end{array}$} & 1 & + & - & - & - & - & - & $\mathrm{E}$ & $\mathrm{E}$ \\
\hline & 3 & $-1 /$ te & $+/ t$ & $+/ t$ & $+/ t$ & $t / t$ & $t / t$ & $\bar{D}$ & SW \\
\hline & 4 & $-1-$ & $-1-$ & $-1+$ & $-1-$ & $-1-$ & $-1-$ & $\mathrm{E}$ & $\mathrm{SW} / \mathrm{NE}$ \\
\hline & 5 & $\overline{t+1 t}$ & $+1-$ & $-1-$ & $+/ t$ & $+/+$ & $t / t$ & $\mathrm{D}$ & $\mathrm{NE} / \mathrm{SW}$ \\
\hline & 7 & $-1+$ & $+/ t$ & $+1-$ & $-1-$ & $-1-$ & $-1-$ & $\mathrm{E}$ & $\mathrm{SW} / \mathrm{NE}$ \\
\hline & 10 & $-1-$ & $-1-$ & $+1+$ & $+/ t$ & $+1-$ & $+1-$ & $\bar{T}$ & $\mathrm{NE}$ \\
\hline & 11 & $+/-$ & $+/-$ & $-1-$ & $-1-$ & $+1-$ & +1 & $\mathrm{~T}$ & $\mathrm{NE}$ \\
\hline & 12 & $+1-$ & $+1-$ & $+/+$ & $+/+$ & $+1-$ & $+1-$ & $\mathrm{T}$ & $\mathrm{NE}$ \\
\hline & 13 & $+1-$ & $+1-$ & $-1-$ & $-1-$ & $+1-$ & $+1=$ & $\mathrm{T}$ & $\mathrm{NE}$ \\
\hline & 14 & $+1 t$ & $+/ t$ & $+1-$ & $+/+$ & $+1-$ & $+1+$ & D & $\mathrm{NE} / \mathrm{SW}$ \\
\hline & 16 & - & - & + & - & + & - & $\mathrm{E}$ & SW \\
\hline \multirow{10}{*}{$\begin{array}{l}\mathrm{V} \\
\mathrm{E} \\
\mathrm{R} \\
\tilde{\mathrm{A}} \\
\mathrm{O}\end{array}$} & 434 & - & - & + & - & - & - & $\mathrm{E}$ & NE \\
\hline & 433 & $t / t$ & $t / t$ & $-1-$ & $t / t$ & $+1-$ & $+1 t$ & D & $\mathrm{NE} / \mathrm{SW}$ \\
\hline & 432 & $-1+$ & $-1+$ & $t / 4$ & $-1-$ & $+1+$ & $-1+$ & $T$ & SW \\
\hline & 431 & $-1+$ & $-1+$ & $-1-$ & $+1+$ & $-1+$ & $-1+$ & $T$ & SW \\
\hline & 417 & $-1-$ & $-1 m$ & $+1-$ & $-1-$ & $-1 m$ & $-1-$ & E & SW/NE \\
\hline & 418 & $+1-$ & $t / t$ & $+/+$ & $+1-$ & $+1-$ & $+1-$ & $\mathrm{T}$ & $\mathrm{NE}$ \\
\hline & 419 & $+1-$ & $-1-m$ & $-1+$ & $+/+$ & $+1-$ & $+1-$ & $T$ & $\mathrm{NE}$ \\
\hline & 420 & $+/ t$ & $+1-$ & $-1-$ & $-1-$ & +1 & +1 & $T$ & $\mathrm{NE}$ \\
\hline & 421 & $-1+$ & $+1 t$ & $+1-$ & $+1-$ & $t / t$ & $t / t$ & D & $\mathrm{NE}$ \\
\hline & 422 & - & - & + & + & - & - & $E$ & SW \\
\hline
\end{tabular}

COOK \& GORSLINE (1972) verificaram que, nas praias ao sul da Califórnia, as correntes de retorno são muito mais ativas nos meses de inverno, devidas a ventos fortes, 
ondas altas e de curto período, mas são muito fracas ou inativas durante as calmarias de verão. Alguns autores têm tentado explicar a origem dessas correntes através de modificações no ângulo de incidência dos trens de ondas. BOWEN \& INMAN (1969) mostraram que, para praias retas e longas, essas correntes são produto da interação entre ondulações geradas fora da costa (swells) e as ondas de ressonância (edge waves). geradas nas proximidades dela. DALRYMPLE (1975) concluiu que trens de ondas de mesma freqüência, criados por diferentes sistemas de geração ou por reflexão, quando se interceptam podem gerar correntes de retorno. Para GUZA \& INMAN (1975) essas correntes estão muito mais relacionadas à instabilidade periódica da deriva litorânea do que ao mecanismo de ondas de ressonância sincrônicas operando com ondas incidentes frontais. De acordo com KOMAR (1991), duas correntes convergentes de deriva litorânea, com ondas se aproximando paralelamente à linha de costa, ou correntes com apenas um sentido preferencial e geradas por ondas que atingem a praia em ângulos $\leq 5^{\circ}$, podem produzir correntes de retorno concentradas. Na área de estudo, ambas possilbilidades podem ser aceitas, como sugerem as medidas de ondas da tabela 3.

De qualquer forma, as correntes que atuam neste trecho devem ser realmente efetivas, pois imprimiram modificações nas isóbatas de 10 até cerca de $27 \mathrm{~m}$, como foram observadas na Carta Náutica da D.H.N. $n^{0} 1700$ (1939-1972). As melhores evidências sobre a existência dessa grande feição parecem ser representadas por trechos erosivos ao sul entre os perfis $7 / 431$ e $10 / 417$ e, ao norte, entre os pontos $15 / 536-A$ e $536-B$, à sotamar do perfil 14/421 e da ampla zona de transporte identificada entre os perfis 11/418 e 13/420. Neste trecho, as características da praia variaram bastante entre si em relação ao inverno e verão, de tal forma que seria difícil identificar alguma tendência sem o uso da matriz de comparação.

As medidas de ondas no campo (tabela 3), durante o inverno, ficaram prejudicadas por problemas com o equipamento. Os valores obtidos durante o verão mostram ligeira predominância de transportes para SW $(58,3 \%)$ e nas medições feitas em dezembro este rumo correspondeu a $90 \%$. Os resultados mostraram que, em geral, as correntes de rumo NE são geradas por ondas de S7-30E, e as de rumo SW, por ondas de S35-70E. Todas as medidas, portanto, indicaram trens de ondas provenientes do quadrante SE. Esses dados estão de acordo com os mostrados em GEOBRÁS (1966, apud TESSLER, 1988), CTHUSPIDAEE (1973) e TESSLER (1988). 
Os resultados de ondas medidas nas fotografias aéreas (tabela 2) são bastante semelhantes aos obtidos no campo.

Assim, o transporte geral na Praia da llha Comprida, obtido pelo método proposto, indicou ligeira prodominância de correntes de deriva litorânea atuando no sentido NE, embora o transporte para SW também seja ativo. No inverno, $57,1 \%$ dos rumos foram para NE, e os $42,9 \%$ restantes apresentaram rumo SW, enquanto que no verão essas freqüências mudaram para $58,3 \%$ e $41,7 \%$, respectivamente.

\section{- Praia do Leste}

A Praia do Leste mostrou características morfológicas e texturais diferentes entre o inverno e o verão, mas quase nenhuma variação foi constatada entre as zonas amostradas em cada perfil.

No inverno constatou-se tendência estreitamento da praia em sua porção central e um grande alargamento no extremo norte (figura 6). No verão, por outro lado, observou-se forte diminuição da largura no setor norte e aumento no centro. Essas diferenças não podem ser explicadas por variações de maré, pois em ambas as etapas a maré era de quadratura (tabela 1). Presume-se que elas estejam associadas à intensa dinâmica da área onde interagem correntes costeiras e os fluxos lagunares (desembocadura de lcapara) e fluviais (foz do Rio Ribeira de Iguape) e também às grandes variações de maré existentes entre os meses de inverno e verão (MESQUITA et al., 1995).

A antepraia apresentou-se menos inclinada no extremo sul e maior no setor central.

O diâmetro médio das areias praticamente não oscilou, ficando muito próximo de 3 phi $(0,125 \mathrm{~mm})$, mas variando entre areias finas $(71,4 \%)$ e muito finas $(28,6 \%)$. De maneira geral, observou-se sensivel afinamento dos grãos de NE para SW, em ambas as etapas (figura 9). Predominam areias muito bem selecionadas $(90,5 \%)$. No inverno o grau de seleção diminuiu na porção central da praia, mas no verão isso ocorreu no extremo sul.

A "matriz de comparação" (quadro 6) revelou tendências diferentes entre o inverno e o verão: 
Quadro 6: Matriz de comparação elaborada para a Praia do Leste

\begin{tabular}{|c|c|c|c|c|c|c|c|c|c|}
\hline \multirow[b]{2}{*}{$\begin{array}{c}\text { Etapa } \\
\text { de } \\
\text { Amost }\end{array}$} & \multirow[b]{2}{*}{$\begin{array}{l}\text { Perfil } \\
\text { Praial }\end{array}$} & \multicolumn{3}{|c|}{ PARÁM. TEXTURAIS } & \multicolumn{2}{|c|}{ MORFOLOGIA } & \multirow[b]{2}{*}{$\begin{array}{l}\text { Resultado } \\
\text { Final }\end{array}$} & \multirow[b]{2}{*}{$\begin{array}{c}\text { PROCESSO } \\
\mathrm{E}=\text { erosão } \\
\mathrm{D}=\text { deposição } \\
\mathrm{T}=\text { transporte }\end{array}$} & \multirow[b]{2}{*}{$\begin{array}{c}\text { SENTIDO } \\
\text { DA } \\
\text { DERIVA }\end{array}$} \\
\hline & & $\begin{array}{l}\text { Diâmetro } \\
\text { Médio }\end{array}$ & $\begin{array}{c}\text { Grau } \\
\text { de } \\
\text { Seleção }\end{array}$ & $\begin{array}{c}\text { Curto- } \\
\text { se }\end{array}$ & $\begin{array}{l}\text { Incli- } \\
\text { nação }\end{array}$ & $\begin{array}{l}\text { Largu- } \\
\text { ra }\end{array}$ & & & \\
\hline \multirow{4}{*}{ INV. } & 17 & + & + & + & + & + & + & $\mathrm{D}$ & SW \\
\hline & 18 & $-1+$ & $-1-$ & $-1-$ & $-1-$ & $-1-$ & $-1-$ & $\mathrm{E}$ & SW/NE \\
\hline & 19 & $-1+$ & $+/ 4$ & $+/ t$ & $+1-$ & $+1-$ & $+1+$ & $\mathrm{D}$ & $\mathrm{NE} / \mathrm{SW}$ \\
\hline & 20 & - & - & - & + & + & - & $\mathrm{E}$ & SW \\
\hline \multirow{3}{*}{ VER. } & 415 & - & - & + & + & - & - & $\mathrm{E}$ & $\mathrm{NE}$ \\
\hline & 414 & $+/-$ & $t / t$ & $-1-$ & $-1 / m$ & $+1+$ & $+1-$ & $T$ & $\mathrm{NE}$ \\
\hline & 413 & + & - & + & + & - & + & $\mathrm{D}$ & $\mathrm{NE}$ \\
\hline
\end{tabular}

(a) No inverno foram encontradas duas células divergentes a partir do perfil 18 (centro da praia), definindo transportes para NE e SW, sendo o extremo sul predominantemente deposicional e o norte erosivo;

(b) No verão uma célula completa pode ser caracterizada, com barlamar no extremo sul e sotamar ao norte.

O sinal negativo do grau de seleção na zona de sotamar do ponto 413 , provavelmente está associado à influência do Rio Ribeira de Iguape na sedimentação local.

Comparando-se esses resultados com as medições de ondas no campo (tabela 3), nas fotos aéreas (tabela 2) e os dados de sensoriamento remoto, nota-se boa correlação, principalmente nos resultados do inverno.

\section{- Juréia}

As larguras medidas ao longo da Praia da Juréia foram consideravelmente maiores no inverno, exceção feita apenas ao perfil 22/411, que permaneceu quase constante e bastante reduzida em relação ao resto da praia. A razão para a diferença de largura é que no inverno atuava uma frente fria instalada desde alguns dias antes das amostragens, enquanto que no verão, o tempo era bom. Isso pode explicar também porque as inclinaçöes foram menores no inverno. Ondas mais altas e de períodos mais curtos, portanto mais enérgicas, tendem a rebaixar os perfis. Durante as calmarias do verão a praia tende a acumular sedimentos na antepraia. As maiores declividades foram encontradas nos perfis 22/411, 25/409 e 25 . 
$\mathrm{Na}$ Praia da Juréia predominam areias finas $(93,9 \%)$ e muito bem selecionadas $(87,9 \%)$ (figura 10$)$. MENEZES (1994) também constatou a predominância de areias finas, porém moderadamente selecionadas.

A "matriz de comparação" (quadro 7) permitiu identificar as seguintes tendências:

(a) Presença de dois pares de células de transporte divergentes a partir dos pontos 23 e 25, no inverno, e dos pontos 411 e 409 no verão;

(b) Nos extremos sul e norte da praia predominam processos deposicionais;

(c) Processos deposicionais também ocorrem na porção central da praia, intermediando as zonas de divergência citadas;

(d) Transportes de rumo SW e NE ocorrem simultaneamente, com ligeira predominância dos primeiros.

A mudança na posição dos centros de divergência de células, com migração de ambas para SW no verão, poderia ser explicada pela predominância de atuação de ondas de ESE, como é sugerido na tabela 3.

Quadro 7: Matriz de comparação elaborada para a Praia da Juréia

\begin{tabular}{|c|c|c|c|c|c|c|c|c|c|}
\hline & \multicolumn{3}{|c|}{ PARÁM. TEXTURAIS } & \multicolumn{2}{|c|}{ MORFOLOGIA } & \multirow[b]{2}{*}{$\begin{array}{c}\text { Resultado } \\
\text { Final }\end{array}$} & \multirow[b]{2}{*}{$\begin{array}{c}\text { PROCESSO } \\
\text { E=erosão } \\
D=\text { deposição } \\
T=\text { transporte }\end{array}$} & \multirow[b]{2}{*}{$\begin{array}{c}\text { SENTIDO } \\
\text { DA } \\
\text { DERIVA }\end{array}$} \\
\hline $\begin{array}{c}\text { Etapa } \\
\text { de } \\
\text { Amost }\end{array}$ & $\begin{array}{l}\text { Perfil } \\
\text { Praial }\end{array}$ & $\begin{array}{c}\text { Diâmetro } \\
\text { Médio }\end{array}$ & $\begin{array}{c}\text { Grau } \\
\text { de } \\
\text { Seleção }\end{array}$ & $\begin{array}{l}\text { Curto- } \\
\text { se }\end{array}$ & $\begin{array}{l}\text { Incli- } \\
\text { nação }\end{array}$ & $\begin{array}{c}\text { Largu- } \\
\text { ra }\end{array}$ & & & \\
\hline \multirow{6}{*}{ INV. } & 21 & + & - & - & + & + & + & $\mathrm{D}$ & SW \\
\hline & 22 & $-1+$ & $+/+$ & $+1-$ & $-/+$ & $-1-$ & $-1+$ & $\mathrm{T}$ & SW \\
\hline & 23 & $-m / m$ & $-1 /-$ & $+1+$ & $-1-$ & $+/-$ & $-1-$ & $E$ & $\mathrm{NE} / \mathrm{SW}$ \\
\hline & 24 & $+1-$ & $+/+$ & $-1+$ & $+/+$ & $+1-$ & $+1+$ & $\mathrm{D}$ & $\mathrm{NE} / \mathrm{SW}$ \\
\hline & 25 & $+/+4$ & $-1-$ & $-1-$ & $-1-$ & $+1-$ & $-1-$ & $E$ & $\mathrm{SW} / \mathrm{NE}$ \\
\hline & 26 & - & + & + & + & + & + & $\mathrm{D}$ & $\mathrm{NE}$ \\
\hline \multirow{5}{*}{ VER. } & 412 & - & - & + & + & + & + & $\mathrm{D}$ & $\mathrm{SW}$ \\
\hline & 411 & $+/+$ & $+/+$ & $-1-$ & $-1-$ & $-1-$ & $-1-$ & $E$ & $\mathrm{SW} / \mathrm{NE}$ \\
\hline & 410 & $-1-$ & $-1+$ & $+/ t$ & $+/+$ & $+1-$ & $+/+$ & $\mathrm{D}$ & $\mathrm{NE} / \mathrm{SW}$ \\
\hline & 409 & $+1-$ & $-1-$ & $-1+$ & $-1-$ & $+1-$ & $-1-$ & $\mathrm{E}$ & $\mathrm{SW} / \mathrm{NE}$ \\
\hline & 408 & + & + & - & + & + & + & $\mathrm{D}$ & $\mathrm{NE}$ \\
\hline
\end{tabular}

O sinal negativo do grau de seleção na zona de sotamar do ponto $21 / 412$, provavelmente está associado à influência do Rio Ribeira de Iguape na sedimentação local. 
Os dados de ondas obtidos estão de acordo com os apresentados por BOMTEMPO (1991) para a região ao norte (setor II).

\section{1. 3. MÉTOdo dE MCLAREN}

Os quadros 8 e 9 (Volume II) apresentam as matrizes de correlação elaboradas para as praias de Ilha Comprida, Leste e Juréia.

A matriz é dividida diagonalmente em dois campos, por quadrículas correspondentes às comparações entre duas amostras iguais $(X X X X X)$ : o campo superior indica transportes para "sul" (no caso, SW), e o campo inferior, transportes para "norte" (NE).

Os resultados obtidos indicam algumas tendências interessantes.

(a) No inverno $27,4 \%$ de todas as comparações foram positivas, das quais $63,5 \%$ corresponderam aos Casos $B(F / M / N)$ e $36,5 \%$ aos Casos $C(G / M / P)$. No verão esses números foram semelhantes: $26,1 \%$ do total foram positivas, com $62,5 \%$ do Caso $\mathrm{B}$ e $37,5 \%$ do Caso $\mathrm{C}$.

(b) Se os casos "A" (F/M/P) fossem contabilizados, ocupariam grandes porcentagens nas duas etapas.

(c) Para o inverno cerca de $56,5 \%$ dos casos indicaram transportes para NE, e $43,5 \%$ para SW. No verão os transportes para NE ocorreram em $40 \%$ dos casos, predominando, portanto, os transportes para SW.

(d) Os cálculos dos indices Z-estatístico para esses transportes sugerem que ambos os sentidos têm consistência estatística (N.S. $=0,01$ ), para o inverno e o verão:

Z- inv $v_{(N E)}=8,11 \quad Z-$ inv $_{(S W)}=4,97$

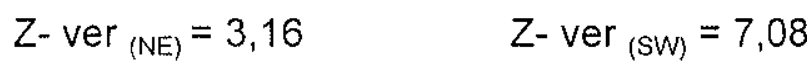

(e) Para os casos B e C, individualmente, e sua associação com os sentidos de transporte, foram encontrados Z-estatísticos confiáveis apenas para os casos B para NE no inverno e B para SW no verão: Z-Binv ${ }_{(\mathrm{NE})}=3,71$ e Z-Bver ${ }_{(\mathrm{SW})}=1,93$.

(f) No inverno a maior parte dos transportes de rumo NE está associada à llha Comprida, enquanto que a maior parte dos transportes para SW ocorre nas praias do Leste e Juréia. 
No verão o mesmo não ocorre, havendo grande participação da llha Comprida nos transportes para SW.

(g) Algumas amostras indicam ser fonte de muitas outras, mas não têm fontes locais, sugerindo predominância de erosão: $5,10,18$ e 25 para o inverno; 419,415 e 409 para o verão.

(h) Algumas amostras têm muitas fontes locais, mas raramente constituem fontes de outros sedimentos, sugerindo predominância de processos deposicionais: 13 e 14 (inverno) e 434, 433,422 e 408.

(i) A Praia do Leste parece se comportar como uma zona de passagem ou trânsito de sedimentos entre a liha Comprida e a Juréia.

\section{1. 4. CONCLUSŌES}

De maneira geral os três métodos utilizados mostraram resultados semelhantes.

O quadro 10 mostra as relações percentuais de transportes obtidas para o setor I, pela comparação entre os métodos utilizados. Alguns desse valores são tendenciosos, como os obtidos para as ondas medidas no campo que, para a llha Comprida, representam somente dados de verão. Os dados de dezembro de 94 foram integrados aos do verão. Por outro lado, no inverno $54,5 \%$ das medidas foram feitas sob condições de tempo instável (final de frente fria), e $45,5 \%$ sob condições de frente fria. No verão $51,9 \%$ das medições ocorreram sob condições de instabilidade e $48,1 \%$ sob condições de calmaria. As fotografias aéreas analisadas correspondem a vôos realizados em condições de tempo bom, e a maioria foi efetuada em meses de inverno. As ondas medidas nas fotos aéreas de 1962 não foram consideradas pelo desconhecimento da data precisa do sobrevôo.

O método de McLAREN relaciona todas as amostras provenientes das diferentes praias e, por isso, os resultados são diferentes dos obtidos pelo método de TAGGART \& SCHWARTZ-modificado, no qual são estabelecidas relações para cada praia, analisando apenas pares ou trios de amostras. Note-se bem que, no inverno, as praias de llha Comprida e Leste estavam sob condições de frontogênese e a Juréia submetida ao tempo instável. No verão, a metade sul da lilha Comprida foi amostrada sob condições de tempo instável e o restante dela, bem como das demais praias, sob tempo bom. Essas diferenças, quando comparadas aos dados do quadro 10 , mostram que mesmo sob condições 
diversas de tempo, os dois rumos de transporte (NE e SW) são importantes em cada praia e atuam concomitantemente. Apesar disso, os grandes sistemas de transporte associados às mudanças meteorológicas podem agir sobre as células locais, deslocando suas zonas de barlamar e sotamar.

Quadro 10. Comparação entre os resultados percentuais dos rumos de transporte obtidos a partir de diferentes métodos utilizados.

\begin{tabular}{|c|c|c|c|c|}
\cline { 2 - 5 } \multicolumn{1}{c|}{} & \multicolumn{2}{c|}{$\begin{array}{c}\text { INVERNO } \\
\text { TRANSPORTE }\end{array}$} & \multicolumn{2}{c|}{\begin{tabular}{c} 
VERÃO (+Dez/94) \\
\cline { 2 - 5 } \multicolumn{1}{c|}{}
\end{tabular}} \\
\hline MÉTODO & NE & $S W$ & NE & SW \\
\hline Taggart \& Schwartz-modif. & $50,0 \%$ & $50,0 \%$ & $60,9 \%$ & $39,1 \%$ \\
\hline McLaren & $56,5 \%$ & $43,5 \%$ & $40,0 \%$ & $60,0 \%$ \\
\hline Ondas - Campo & $35,7 \%$ & $64,3 \%$ & $29,7 \%$ & $70,3 \%$ \\
\hline Ondas - Fotos Aéreas & $48,0 \%$ & $52,0 \%$ & $33,3 \%$ & $66,7 \%$ \\
\hline
\end{tabular}

Conclui-se que, para o setor I, os transportes de rumos NE e SW ocorrem concomitantemente, atuando através de células de deriva litorânea divergentes e convergentes. Os centros de divergência dessas células podem migrar ao longo de um curto trecho da praia, para sul ou para norte, de acordo com a direção principal de incidência de ondas.

Durante a passagem das frentes frias, quando as ondas incidem de SSW-S-SSE, parecem predominar transportes regionais para NE. Entretanto, na maior parte do tempo, quando as ondas de SE incidem com ângulos maiores, os transportes para SW podem predominar. BOMTEMPO (1991) obteve resultados semelhantes para as praias ao norte (Rio Verde e Una). Esses padrões de transporte de caráter regional parecem ser os responsáveis pelas migrações das zonas de barlamar das células locais, deslocando-as para norte ou para sul.

As inversões no sentido de transporte causadas por essas pequenas células parecem resultar da interação entre um trem de ondas principal (ondulações geradas fora 
da costa) e um segundo trem, provavelmente gerado nas proximidades da costa. Este trem secundário pode corresponder a ondas de ressonância (edge waves), uma vez que a costa é bastante longa, reta e aberta. As medidas de ondas efetuadas sobre fotografias aéreas, confirmam a atuação conjunta de um trem de ondas principal e de um secundário (tabela 2). As ondas do trem principal apresentam cristas arredondadas, regulares e bem definidas e pequena esbeltez, enquanto que no trem secundário as cristas são agudas, com esbeltez alta e direção de propagação irregular.

No campo, apenas as ondas mais regulares puderam ser visualizadas. É interessante notar que essas medidas (na liha Comprida foram efetuadas apenas no verão de 93 e em dezembro de 94) revelam a predominância de derivas para SW, associadas a ondas de rumo médio S51E para a liha Comprida, S38E para a Praia do Leste e S47E para a Juréia. Comparativamente, nas fotos aéreas os valores médios obtidos para as ondas geradoras de correntes SW foram: S51E para a Ilha Comprida, S47E para a Praia do Leste e S47E para a Juréia. As ondas geradoras de transportes NE medidas nas fotografias aéreas, em geral, correspondiam ao trem secundário. Foram obtidos os seguintes rumos médios para ondas medidas no campo e sobre as fotografias aéreas: Ilha Comprida - S44E e S22E, Praia do Leste - S35E e S30E, e Juréia - S38E e S75E.

As principais tendências observadas na llha Comprida foram:

(a) Amplo centro de divergência de células no setor sul-central (entre os pontos 7/431 e 10/417), com predomínio de processos erosivos (fotos 1 e 2 ), podendo haver migrações das zonas de barlamar;

(b) Convergência de duas células de deriva litorânea (a maior proveniente de norte) no setor sul, próximo ao perfil 5/432, com embaiamentos na praia, podendo haver correntes de retorno e migrações para sul;

(c) Atuação de correntes de retorno no setor centro-norte da praia (trecho entre os perfis $11 / 418$ e 12/419), podendo causar embaiamentos na praia e apresentar variações de intensidade ou deslocamentos (até o ponto 14/421) ao longo do ano;

(d) Fortes processos erosivos, com acentuado embaiamento na praia, ocorrem no trecho entre os pontos $15 / 536 \mathrm{~A}$ e $536 \mathrm{~B}$, sugerindo ser uma área de divergência de pequenas células;

(e) Intensos processos deposicionais nas desembocaduras lagunares de Cananéia e Icapara; 
(f) Processos mistos, deposicionais e erosivos, nos extremos da praia;

(g) Transportes costa adentro-costa afora também podem ocorrer ao longo da praia, com a incidência de ondas normais à linha de costa, como foi verificado nas medições de campo e em fotografias aéreas.

Os resultados obtidos aqui divergem parcialmente dos apresentados por BARCELOS (1975), TESSLER (1988) e PONÇANO et al. (1994, in NAKAZAWA, et al.,1994), que propuseram a predominância de correntes para NE atuando ao longo de toda a Iha. Os últimos autores assinalaram também a presença de transportes costa adentro e costa afora nas porções sul e norte da praia (figura 3). SOARES \& ALFREDINE (1996), por outro lado, baseados no estudo do plano de refração de ondas de $E$ e $S$ em águas profundas, concluíram que, pelo maior indice enérgico das ondas de $\mathrm{E}$, o transporte litorâneo ao longo dessa praia se dá predominantemente para SW.

A Praia do Leste parece comportar-se como "zona de passagem" ou "trânsito" de sedimentos entre a llha Comprida e a Praia da Juréia. Está também fortemente sujeita às dinâmicas das desembocaduras lagunar e fluvial. Como conseqüência, ao largo dessa praia ocorre uma zona de intensa deposição, bem marcada sobre fotografias aéreas, imagens de satélite e nas cartas náuticas. As irregularidades produzidas no fundo por fatores hidrodinâmicos, interferem na incidência das ondas, provocando a elevação nos seus ângulos. Com isso, pequenas células de deriva litorânea são geradas cujos rumos dependerão dos vários fatores que interagem na área. Essas modificações podem também interferir nas praias de llha Comprida e Juréia.

$\mathrm{Na}$ Juréia os resultados mostram, basicamente, a atuação de dois pares de células divergentes, com zonas de barlamar situadas ao norte e no setor centro-sul da praia, podendo ocorrer migrações das mesmas. Os dois extremos dessa praia são áreas predominantemente deposicionais (sotamares), ocorrendo transporte generalizado para SW.

PONÇANO et al. (1994, in NAKAZAWA, et al.,1994) sugerem a atuação de correntes para SW e também de transportes costa adentro-costa afora para a Praia da Juréia (figura 3). 
Os locais onde foram observadas evidências de processos erosivos nessas praias coincidiram com as zonas de barlamar de células identificadas pelo Método de TAGGART \& SCHWARTZ-modificado e a depósitos em erosão pelo Método de McLAREN.

\section{2. SETOR MORFODINÂMICO II}

Neste setor foram estudadas as praias de Rio Verde/Itacolomi, Una e Guaraú.

\section{2. 1. Análise de Produtos de Sensoriamento Remoto}

As fotografias aéreas utilizadas correspondem aos vôos utilizados foram os de 1962 , 1966, 1973 e 1994 (somente Guaraú) (quadro 3) e os resultados obtidos encontram-se na figura 11. A tabela 4 mostra as medidas de ondas e os prováveis rumos das correntes de deriva litorânea geradas por aquelas ondas.

$\mathrm{Na}$ Praia do Rio Verde encontram-se evidências de atuação de duas células maiores, divergentes a partir da sua porção central. A barra de desembocadura do Rio Verde sempre apresenta-se bem alongada para sul.

$\mathrm{Na}$ Praia do Itacolomi, os transportes predominantes parecem ser dirigidos para SW, em toda a sua extensão.

O segmento sul da Praia do Una (Una-Sul) parece corresponder a área de sotamar. Entre os perfis $64 / 522$ e 63 , o forte estreitamento da praia e o baixo ângulo formado entre as ondas incidentes e a praia (tabela 4) sugerem transportes bidirecionais, com divergência neste local. A partir deste trecho, rumo ao Rio Una, predominam transportes para NE conforme sugerido pelo alargamento progressivo da praia, o deslocamento da desembocadura do Córrego Barra Velha para norte e o ângulo de incidência das ondas. Nas imagens de satélite de 1976 e da década de 90, no entanto, os transportes ao longo deste trecho parecem ser predominantemente para SW, com plumas de suspensão deslocadas neste sentido, como nas fotos de 1962. 
No segmento Una-Norte, o estreitamento da praia na porção central e o baixo ângulo formado entre as ondas incidentes e a praia sugerem transportes bidirecionais, com centro de divergência neste local.

Os fluxos do Rio Una parecem ser mais intensos que as correntes de deriva litorânea que atuam na sua desembocadura, pois praticamente não sofrem deslocamento lateral, atingindo o largo com facilidade e criando ali uma zona de deposição.

Ao redor do Costão da Deserta predominam transportes para sul.

Na Praia de Guaraú não foi possivel estabelecer tendências predominantes, pois ocorreram muitas modificações decorrentes de intervenções antrópicas. MENEZES (1994) reconstituiu as mudanças da desembocadura do Rio Guaraú a partir das fotografias aéreas de 1962 até 1973. Nas fotografias de 1962 é possivel observar que a desembocadura deste rio situava-se no extremo norte. Em 1966 estava no extremo sul e em 1973 no meio da praia. Na década de 80 havia duas desembocaduras, uma principal, no centro da praia e outra ao sul, ambas conectadas por uma canal paralelo à linha de costa, e separadas por um banco arenoso parcialmente submerso (ALFREDINE, com. pessoal). Em 1987, já estando ocupado todo o trecho entre o centro e o norte da praia, iniciou-se a obra de enrocamento da margem esquerda do rio, cujo canal foi desviado para o extremo sul. Como conseqüência dessa obra, houve intensa deposição de sedimentos em todo o trecho ocupado pelo antigo banco arenoso, com o preenchimento total do prisma praial até a ponta do espigão do enrocamento. Este fenômeno revela a existência de um transporte resultante para sul, pelo menos a partir da porção central da praia, onde se instalou um intenso processo erosivo (vide capítulo VII).

De modo geral, os resultados obtidos sugerem a atuação de correntes de NE e de SW, atuando nessas praias com ligeiro predominio do NE. Nas imagens de satélite de 1976 e da década de 90 , as tendências principais de transporte são para SW.

As ondas medidas sobre as fotografias aéreas (tabela 4), propagando-se predominantemente de SE, sugerem transportes bidirecionais, ora divergentes, ora convergentes ao longo de todas as praias.

Nas imagens de satélite de 1976 e da década de 90 observam-se transportes gerais para SW, desde o Guaraú até a Praia do Rio Verde. Nesta última, é muito clara a 
ocorrência de um centro de dispersão (divergência) no seu setor central, originando transportes para NE e SW.

\section{2. 2. MÉTODO DE TAGGART \& SCHWARTZ-MODIFICADO}

A figura 12 mostra os resultados obtidos para o setor II, pela aplicação deste método. Na tabela 5 encontram-se as medidas de ondas efetuadas no campo e os rumos prováveis das correntes geradas por elas.

As figuras 13 e 14 mostram os gráficos de variação de largura e inclinação das praias do setor II.

\section{- Rio Verde e Itacolomi}

Em geral, estas praias mudaram pouco durante as duas etapas de amostragem.

As larguras medidas no inverno foram consideravelmente menores que no verão, fato que pode ser explicado pelas diferentes condições de maré e meteorológicas atuantes nas duas épocas: no inverno - maré vazante de sizígia e com frente fria; no verão preamar de quadratura e tempo bom. No verão, não foi possivel o levantamento do perfil na Praia de Itacolomi porque a maré encobria a passagem entre esta praia e a do Rio Verde. Na porção central da Praia do Rio Verde a largura é bem menor e a inclinação do perfil maior do que nas suas extremidades.

Nessas praias predominam areias médias $(93,3 \%)$, moderadamente $(53,3 \%)$ a bem selecionadas (40\%). MENEZES (1994) encontrou areias médias e bem selecionadas. O comportamento textural da Praia do Rio Verde apresentou algumas variações entre 0 inverno e o verão (figura15). Verificou-se, para ambas as etapas, um relativo afinamento das areias a partir da porção centrał para as extremidades da praia. O grau de seleção, por outro lado, mostrou-se melhor no centro dessa praia no inverno, tendo piorado no verão. Essas mudanças poderiam ser explicadas pelas variações de energia ao longo da praia, associadas à atuação da frente fria no inverno. A maior energia no setor central da praia (zona de barlamar) causaria erosão mais rápida e intensa nesse local, com a lavagem dos finos, e conseqüente engrossamento do depósito residual e melhoria do selecionamento em relação aos sedimentos a sotamar. Somado a isso, a descarga do Rio Verde, mais 
elevada durante as chuvas, também poderia ter contribuido para reduzir o grau de seleção no extremo sul da praia devido à entrada de sedimentos continentais.

A "matriz de comparação" (quadro 11) mostra uma zona de barlamar no perfil 67/525, confirmando a hipótese levantada acima. A amostra 66 (Praia do Itacolomi) se comportou como zona de sotamar da célula proveniente da Praia do Rio Verde, sugerindo possibilidade de intercâmbio entre as duas praias. Os sinais negativos obtidos para as zonas de sotamar foram explicados anteriormente.

Quadro 11: Matriz de comparação elaborada para as praias do Rio Verde e Itacolomi

\begin{tabular}{|c|c|c|c|c|c|c|c|c|c|}
\hline & \multicolumn{3}{|c|}{ PARAM. TEXTURAIS } & \multicolumn{2}{|c|}{ MORFOLOGIA } & \multirow[b]{2}{*}{$\begin{array}{c}\text { Resultado } \\
\text { Final }\end{array}$} & \multirow[b]{2}{*}{$\begin{array}{c}\text { PROCESSO } \\
\text { E=erosão } \\
\text { D=deposição } \\
T=\text { transporte }\end{array}$} & \multirow[b]{2}{*}{$\begin{array}{c}\text { SENTIDO } \\
\text { DA } \\
\text { DERIVA }\end{array}$} \\
\hline $\begin{array}{l}\text { Etapa } \\
\text { de } \\
\text { Amost }\end{array}$ & $\begin{array}{l}\text { Perfil } \\
\text { Praial }\end{array}$ & $\begin{array}{c}\text { Diâmetro } \\
\text { Médio }\end{array}$ & $\begin{array}{c}\text { Grau } \\
\text { de } \\
\text { Seleção }\end{array}$ & $\begin{array}{l}\text { Curto- } \\
\text { se }\end{array}$ & $\begin{array}{l}\text { Incli- } \\
\text { nação }\end{array}$ & $\begin{array}{l}\text { Largu- } \\
\text { ra }\end{array}$ & & & \\
\hline \multirow{3}{*}{ INV. } & 68 & + & - & - & + & + & + & $\mathrm{D}$ & SW \\
\hline & 67 & $-1-$ & $+1+$ & $+1-$ & $-1-$ & $-1+$ & $-1-$ & $E$ & SW/NE \\
\hline & 66 & + & - & + & + & - & + & D & $\mathrm{NE}$ \\
\hline \multirow[t]{2}{*}{ VER. } & 524 & + & + & + & + & + & + & $\mathrm{D}$ & SW \\
\hline & 525 & - & - & - & - & - & - & $\mathrm{E}$ & SW \\
\hline
\end{tabular}

- Una

Os comportamentos morfológico e textural da Praia do Una foram muito semelhantes nas duas etapas de amostragem.

No segmento Una-Sul, a largura da praia é menor na porção centro-sul, aumentando progressivamente rumo ao extremo sul e ao Rio Una. No segmento UnaNorte, a porção central é mais estreita. Os trechos mais largos correspondem às proximidades da desembocadura do Rio Una.

A inclinação da praia mostrou-se fortemente elevada no setor centro-sul do segmento Una-Sul, em especial no perfil 64/522, onde a antepraia atingiu inclinações de até $10^{\circ}$. Na Praia Una-Norte, cujos perfis são bem mais suaves que no outro segmento, 0 centro da praia revelou-se pouco mais inclinado em relação aos extremos. $\mathrm{Na}$ antepraia do segmento Una-Sul a média das inclinações foi de $5,7^{\circ}$, e de apenas $1,1^{\circ}$ no segmento Una-Norte. 
Os gráficos de comportamento textural (figura 16) mostram variações marcantes ao longo da praia e nas duas fases de amostragem. Embora predominem areias finas (53,3 $\%$ ) e muito bem selecionadas $(66,7 \%)$, são também importantes as areias muito finas $(33,3 \%)$ e as médias $(13,3 \%)$, que estão presentes em determinados locais, assim com os termos de seleção moderada $(20 \%)$ e boa $(13,3 \%)$. Em geral, as areias são relativamente mais grossas no setor centro-sul do segmento Una-Sul (perfis 64/522 e 63) e afinam rumo ao extremo sul e à desembocadura do Rio Una. No segmento norte as areias são relativamente mais finas que no segmento sul, estando os termos mais grossos na extremidade norte. O grau de seleção mostrou tendências semelhantes de comportamento, sendo relativamente pior selecionadas no trecho centro-sul do segmento Una-Sul e melhorando rumo aos extremos desse segmento, até a Una-Norte. MENEZES (1994) encontrou areias muito finas e muito bem selecionadas nas proximidades do Rio Una e areias médias e moderadamente selecionadas no setor sul.

Mudanças importantes no comportamento textural também foram identificadas entre as duas etapas de amostragem. Do inverno para o verão houve afinamento geral das areias no setor central a sul da Praia Una-Sul. Esta variação poderia ser explicada pela maior dinâmica de sedimentação que atua durante o inverno, associada à passagem de frentes frias, cujas ondas mais esbeltas e mais enérgicas seriam capazes de transportar sedimentos mais grossos e colocá-los na praia, retrabalhando-os parcialmente. Nas calmarias de verão, por outro lado, a competência de transporte seria menor, reduzindo o tamanho dos grãos e também o grau de seleção dos mesmos. BOMTEMPO (1991) observou transporte de material grosso para o largo durante condições de mar agitado (frente fria) e, em coletas na praia após ressacas, obteve diâmetros médios até maiores que $0,500 \mathrm{~mm}$ (areias grossas).

A "matriz de comparação" (quadro 12) revelou tendências bastante semelhantes com as encontradas a partir da análise de produtos de sensoriamento remoto.

Uma zona predominantemente erosiva foi encontrada no setor centro-sul da Praia do Una-Sul, entre os pontos 64/522 e 63, onde ocorre um centro de divergência de duas células de transporte orientadas para NE e SW. A primeira tem o sotamar junto ao Rio Una e a outra, na extremidade sul da praia. Esses dados estão de acordo com observações de campo, onde processos erosivos ocorrem (foto 4). No segmento Una-Norte o extremo sul da praia (perfil 29/384) é zona predominantemente deposicional (sotamar), tanto em 
relação a este segmento, quanto em relação à praia ao sul do Rio Una (perfil 60/520). No inverno, a zona de barlamar desta célula encontrava-se no extremo norte (ponto 27). No verão fica a dúvida sobre onde estaria o barlamar da célula, pois a amostra coletada ao norte (perfil 382) não foi analisada (extraviada). Ressalta-se que o resultado obtido para o perfil 60/520 indicou ser zona de transporte (T) nas duas etapas. Isto significa que ele é deposicional em relação à célula com barlamar no ponto $64 / 522$, mas erosiva em relação ao ponto 29/384. Esses resultados, além de sugerirem transporte para NE entre os dois segmentos, também estão de acordo com os dados de campo, onde processos erosivos na margem direita do Rio Una podem ser detectados. Por outro lado, nas duas margens desse rio também é evidente a dinâmica associada às correntes fluviais e de maré.

Quadro 12: Matriz de comparação elaborada para a Praia do Una

\begin{tabular}{|c|c|c|c|c|c|c|c|c|c|}
\hline \multirow[b]{2}{*}{$\begin{array}{c}\text { Etapa } \\
\text { de } \\
\text { Amost }\end{array}$} & \multirow[b]{2}{*}{$\begin{array}{l}\text { Perfil } \\
\text { Praial }\end{array}$} & \multicolumn{3}{|c|}{ PARÂM. TEXTURAIS } & \multicolumn{2}{|c|}{ MORFOLOGIA } & \multirow[b]{2}{*}{$\begin{array}{c}\text { Resultado } \\
\text { Final }\end{array}$} & \multirow[b]{2}{*}{$\begin{array}{c}\text { PROCESSO } \\
\text { E=erosão } \\
\text { D=deposição } \\
T=\text { transporte }\end{array}$} & \multirow[b]{2}{*}{$\begin{array}{c}\text { SENTIDO } \\
\text { DA } \\
\text { DERIVA }\end{array}$} \\
\hline & & $\begin{array}{c}\text { Diâmetro } \\
\text { Médio }\end{array}$ & $\begin{array}{c}\text { Grau } \\
\text { de } \\
\text { Seleção }\end{array}$ & $\begin{array}{l}\text { Curto- } \\
\text { se }\end{array}$ & $\begin{array}{l}\text { Incli- } \\
\text { nação }\end{array}$ & $\begin{array}{c}\text { Largu- } \\
\text { ra }\end{array}$ & & & \\
\hline \multirow{9}{*}{$\begin{array}{c}\mathrm{I} \\
\mathrm{N} \\
\mathrm{V} \\
\mathrm{E} \\
\mathrm{R} \\
\mathrm{N} \\
\mathrm{O}\end{array}$} & 65 & + & + & + & + & + & + & $\mathrm{D}$ & SW \\
\hline & 64 & $-1-$ & $-1+$ & $-1+$ & $-1-$ & $-1-$ & $-1+$ & $\mathrm{E}$ & $\mathrm{SW} / \mathrm{NE}$ \\
\hline & 63 & $+/-$ & $-1-$ & $-1-$ & $+1-$ & $+1+$ & $+/-$ & $\mathrm{T}$ & $\mathrm{NE}$ \\
\hline & 62 & $+1-$ & $+1 / 2$ & $+1+$ & $+/+$ & $-1-$ & $+1-$ & $T$ & $\mathrm{NE}$ \\
\hline & 61 & $+1-$ & $+1 / m$ & $-1-$ & $-1-$ & $+1+$ & $+1-$ & $\mathrm{T}$ & $\mathrm{NE}$ \\
\hline & 60 & $+1+$ & $+1-$ & $+1-$ & $+1-$ & $-1-$ & $+1-$ & $\mathrm{T}$ & $\mathrm{NE}$ \\
\hline & 29 & $-1-$ & $+1+$ & $+1+$ & $+/+$ & $+1 /+$ & $+1+$ & $\mathrm{D}$ & $\mathrm{NE} / \mathrm{SW}$ \\
\hline & 28 & $+1+$ & $-m / m$ & $-1+$ & $-1+$ & $-1-$ & $-1+$ & $T$ & SW \\
\hline & 27 & - & + & - & - & + & - & $E$ & $\mathrm{SW}$ \\
\hline \multirow{6}{*}{$\begin{array}{l}\mathrm{V} \\
\mathrm{E} \\
\mathrm{R} \\
\tilde{\mathrm{A}} \\
\mathrm{O}\end{array}$} & 523 & + & + & + & + & + & + & $\mathrm{D}$ & SW \\
\hline & 522 & $-1-$ & $-1 / m$ & $-1-$ & $-1-$ & $-1-$ & $-1-$ & $\mathrm{E}$ & SW/NE \\
\hline & 521 & $+1-$ & $+1-$ & $+1-$ & $+1-$ & $+1-$ & $+1-$ & $\mathrm{T}$ & $\mathrm{NE}$ \\
\hline & 520 & $+/+$ & $+/-$ & $+1-$ & $+/+$ & $+1-$ & $+1-$ & $T$ & $\mathrm{NE}$ \\
\hline & 384 & $-1+$ & $+1-$ & $+/+$ & $-1-$ & $+/+$ & $+1+$ & $\mathrm{D}$ & $\mathrm{NE} / \mathrm{SW}$ \\
\hline & 383 & - & $\therefore$ & - & + & - & - & $\mathrm{E}$ & SW \\
\hline
\end{tabular}

Os rumos de correntes, obtidos a partir das medições de ondas no campo (tabela 5), revelam para o segmento do Una-Sul a predominância de transporte para NE $(71,4 \%)$ durante frentes frias no inverno, mas para SW durante condições de (75\%) tempo bom, como no verão. Em junho de 96 (tempo bom), todos os rumos medidos também indicaram transporte para SW. As ondas responsáveis pelos rumos de correntes para NE têm valor médio de S42E, e as geradoras de correntes SW incidem em média de S56E. No 
segmento Una-Norte todos os dados indicaram rumos para SW, associados a ondas de S55E (valor médio). Os valores médios de ondas obtidos nas fotografias aéreas para os transporte NE e SW foram, respectivamente, de S40E e S50E (tabela 4).

Todos esses resultados coincidem com os obtidos por BOMTEMPO (1991), que concluiu não haver variações no comportamento das correntes que atuam nessa praia e na do Rio Verde, em diferentes estações do ano, estando as mudanças relacionadas à passagem de frentes frias. Segundo o autor, durante o tempo bom (calmaria) predominam transportes para SW (75\% das medidas efetuadas no ano), que rapidamente são revertidas para NE em condições pré-frontais e frontais.

\section{- Guaraú}

Nesta praia foram feitas amostragens em três locais no inverno, porém apenas um perfil foi levantado no verão (centro da praia). Foi verificado que a largura da praia aumenta progressivamente de sul para norte, mas a inclinação média mostrou-se pouco maior na porção central.

As areias são finas e muito bem selecionadas, sendo relativamente mais grossas ao sul e pior selecionadas na porção central (figura 17).

A "matriz de comparação" (quadro 13) mostrou uma célula completa com barlamar ao sul e sotamar no extremo norte, sugerindo transportes para norte no inverno.

Quadro 13: Matriz de comparação elaborada para a Praia do Guaraú

\begin{tabular}{|c|c|c|c|c|c|c|c|c|c|}
\cline { 2 - 9 } & \multicolumn{3}{|c|}{ PARÁM. TEXTURAIS } & \multicolumn{2}{c|}{ MORFOLOGIA } & \\
\hline $\begin{array}{c}\text { Etapa } \\
\text { de } \\
\text { Amost }\end{array}$ & $\begin{array}{c}\text { Perfil } \\
\text { Praial }\end{array}$ & $\begin{array}{c}\text { Diâmetro } \\
\text { Médio }\end{array}$ & $\begin{array}{c}\text { Grau } \\
\text { Seleção }\end{array}$ & $\begin{array}{c}\text { Curto- } \\
\text { se }\end{array}$ & $\begin{array}{c}\text { Incli- } \\
\text { nação }\end{array}$ & $\begin{array}{c}\text { Largu- } \\
\text { ra }\end{array}$ & $\begin{array}{c}\text { Resultado } \\
\text { Final }\end{array}$ & $\begin{array}{c}\text { PROCESSO } \\
\text { E=erosão } \\
\text { D=deposição } \\
\text { T=transporte }\end{array}$ & $\begin{array}{c}\text { SENTIDO } \\
\text { DA } \\
\text { DERIVA }\end{array}$ \\
\hline \multirow{2}{*}{ INV. } & 32 & - & + & - & + & - & - & E & NE \\
\cline { 2 - 10 } & 31 & $+/-$ & $-/-$ & $+/+$ & $-/-$ & $+/-$ & $+/-$ & $\mathrm{T}$ & $\mathrm{NE}$ \\
\hline
\end{tabular}

As ondas medidas no campo (tabela 5), no entanto, sugerem correntes para sul a partir dos pontos 30 e 31 e para norte apenas no ponto 32. As ondas medidas no verão também indicam transportes para sul a partir do centro da praia. 
Pelo exposto no item sobre a análise de produtos de sensoriamento remoto, há fortes evidências de transporte geral predominante para sul, pelo menos a partir do centro da praia, que é o trecho de maior erosão (foto 5 ). Em observações detalhadas feitas recentemente nessa praia, a pedido da prefeitura de Peruíbe e do Ministério Público, pôdese perceber que há uma dinâmica mais complexa devido às interferências causadas nas ondas, peio espigão do enrocamento já parcialmente submerso e pelos enormes blocos de rochas colocados à frente de várias casas para tentar conter a erosão marinha (vide capitulo VII). Essas estruturas rígidas funcionam como defletores das ondas que atingem a praia, gerando uma circulação complexa, que exige estudos bem mais detalhados.

\section{2.3. MÉTODO DE MCLAREN}

Os quadros 14 e 15 (Volume II) mostram as matrizes de correlação elaboradas para este setor. Em ambos pode-se constatar claramente a forte predominância de transporte para NE, desde a Praia do Rio Verde até a do Guaraú. Os transportes para SW, sugerindo células menores, ocorrem principalmente do sul da Praia do Una até a do Rio Verde. Centros de divergência de células são bem marcados nos pontos 64/522 e 63 na Praia do Una e no ponto $67 / 525$ na Praia do Rio Verde.

São destacadas abaixo algumas tendências gerais.

(a) As correlações positivas (casos possíveis) perfizeram cerca de $32,6 \%$ no inverno, e $34,3 \%$ no verão.

(b) No inverno, cerca de $81,9 \%$ do transporte exibiu rumo para NE (Z-estatístico $=13,57$ ), valor que se elevou para $88,2 \%$ no verão (Z-estatístico $=5,30$ ). Os Z-estatísticos calculados para os transportes rumo ao SW não atingiram os niveis exigidos de significância.

(c) Os casos $\mathrm{B}(\mathrm{F} / \mathrm{M} / \mathrm{N})$ predominaram nas duas etapas: $79,2 \%$ no inverno (Z-estatístico válido apenas para o rumo $N E=11,80$ ) e $70,6 \%$ no verão (Z-estatístico válido apenas para o rumo $N E=3,28$ ).

(d) Mesmo que os casos " $A$ " fossem computados, ainda haveria predominância do transporte para NE. 
(e) Algumas amostras são fonte da maioria das demais, mas não apresentam fontes locais sugerindo processos erosivos: amostras 68,64 e 63 (inverno) e amostras 525 e 522 (verão).

(f) A amostra coletada no ponto 30 não representa fonte de qualquer outra, mas parece ser suprida por muitas fontes locais, sugerindo ser área predominantemente deposicional.

(g) A Praia do Guaraú parece ser suprida por muitas fontes locais, porém contribui apenas com o extremo norte da Praia do Una. Isto significa que ela pode constituir fonte das praias menores ao sul, como Guarauzinho e Arpoador, que não foram amostradas, ou que parte dos sedimentos que fazem parte do sistema de intercâmbio entre as praias desse setor estejam aprisionados no Guaraú. Com a construção do enrocamento houve intenso processo deposicional no trecho sul da Praia do Guaraú, resultando no preenchimento do prima praial até a ponta do espigão, e forte processo erosivo nas duas praias ao sul citadas acima (vide capítulo VII). Por outro lado, a Praia do Guaraú pode também estar fornecendo sedimentos para praias ao norte, como Peruibe.

\section{2. 4. CONCLUSÕES}

O quadro 16 mostra as relações percentuais dos rumos de transporte obtidas pelos diferentes métodos usados. Os rumos de incidência das ondas medidos nas fotografias aéreas de 1962 não foram computadas pelo desconhecimento da data do sobrevôo. Os dados relativos às medidas de ondas feitas em junho de 1996 não foram incluídos no inverno, porque as condições meteorológicas na época eram de tempo bom, diferentemente do inverno de 1992, quando variaram de frente fria a tempo instável. Pelos os dados de 1996, 100\% das medidas indicaram transporte para SW.

No inverno $53,3 \%$ das medidas foram feitas sob condições de frente fria e $46,2 \%$ sob tempo instável (final de frente fria). No verão $100 \%$ das medidas foram realizadas em tempo bom. Essas cifras, comparadas às medidas obtidas no campo, sugerem que sob condições de tempo bom predomina transporte para SW, enquanto que sob condições de frente fria o transporte ocorre principalmente para NE. Em tempo instável parece haver derivas em ambos os rumos. 
$O$ método de MCLAREN relaciona todas as amostras das diferentes praias e, por isso, os resultados são distintos do método de TAGGART \& SCHWARTZ-modificado, onde relações de pares ou trios de amostras de cada praia são analisadas.

No inverno, as praias do Rio Verde e Itacolomi e Una-Sul foram amostradas durante uma frente fria, enquanto que durante as amostragens das praias do Una-Norte e Guaraú o tempo estava instável (final de frente fria). No verão, por outro lado, o tempo estava bom durante a amostragem de todas as praias. Essas relações explicam os resultados obtidos pelo método de TAGGART \& SCHWARTZ-modificado.

Quadro 16. Comparação entre os resultados percentuais dos rumos de transporte obtidos a partir de diferentes métodos utilizados.

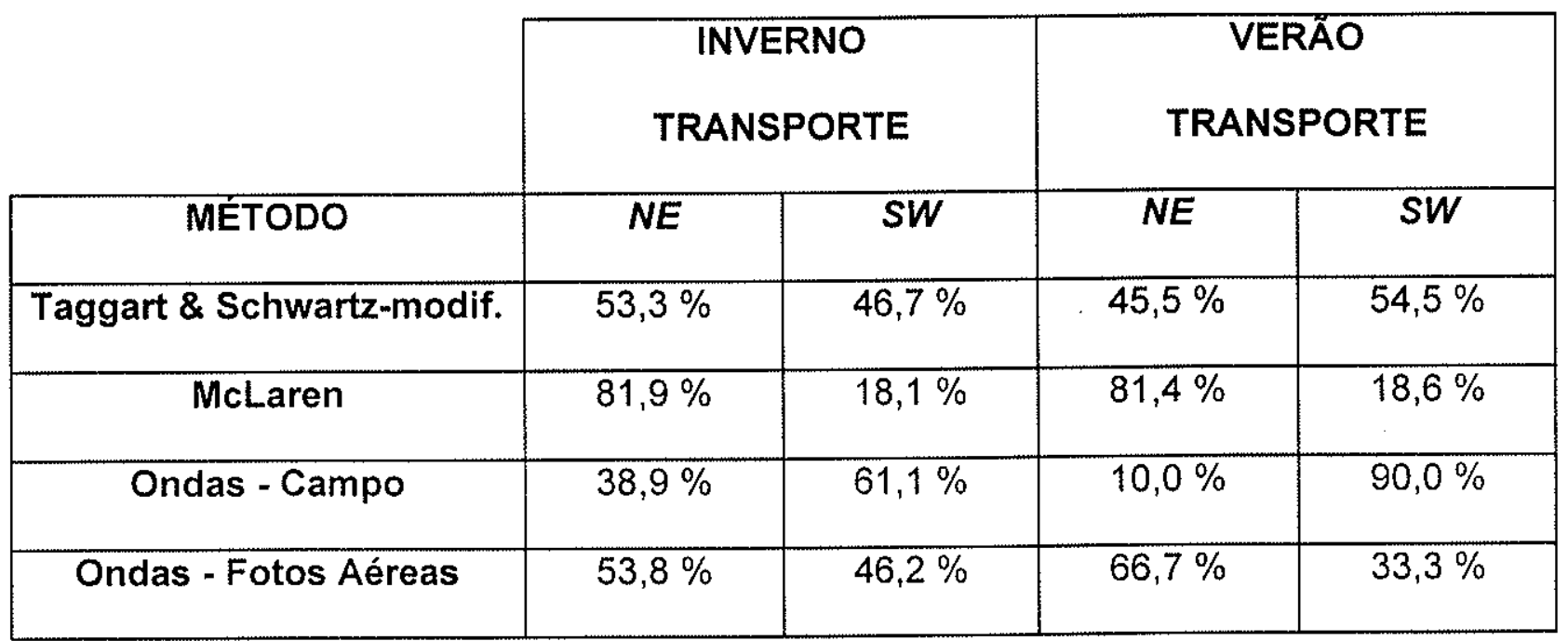

Há ainda outro aspecto que merece reflexão, relacionado às respostas texturais dos sedimentos na Praia do Una-Norte, que levaram à predominância de transporte para NE nas duas etapas de amostragem. Três explicações podem ser sugeridas como possíveis para a compreensão do fato.

(a) A maior efetividade das ondas de inverno e, conseqüentemente, a maior capacidade de erosão e transporte das correntes geradas por elas, resultam em eventos sedimentares mais expressivos que aqueles relacionados às calmarias do verão.

(b) Algumas amostras coletadas no verão, particularmente as da Praia do Una-Sul, podem estar representando eventos sedimentares produzidos durante frentes frias que antecederam as épocas de amostragem. 
(c) BOMTEMPO (1991) concluiu que durante as calmarias (tempo bom) predominam os transportes para SW e, durante a atuação dos sistemas frontais, as correntes se invertem e rumam para NE. O autor trabalhou com dados de ondas e correntes obtidos entre 1982 e 1985. Este periodo parece bastante irregular em termos meteorológicos pois, segundo SANT'ANNA NETO (1994), 1983 foi muito chuvoso e 1985 foi bastante seco. Além disso, é sabido que entre 1983-1984 houve forte atuação do El Niño. Assim, as medições de BOMTEMPO (1991) poderiam estar registrando um periodo anômalo, não correspondendo portanto aos padrões normais.

As duas primeiras poderiam ser as explicações mais prováveis. As interpretações de BOMTEMPO (1991), por outro lado, são parcialmente corroboradas nesta pesquisa, quando inferidos os transportes predominantes sob cada condição meteorológica. Assim, condições climáticas desfavoráveis dos anos 1983 e 1985, podem ter se contrabalançado, permitindo que as interpretações de BOMTEMPO (1991) tivessem representatividade estatística adequada. Não obstante, essas tendências são bastante lógicas para um litoral com orientação geral NE-SW, onde as ondas associadas a frontogêneses incidem de SSW-S-SSE, e as associadas a tempo bom são predominantemente provenientes de SE. ESE-E.

Deste modo, os resultados obtidos sugerem que os dois rumos de transporte sempre ocorrem em todas as praias, mas um pode predominar sobre o outro, de acordo com as condições meteorológicas. Em condições de tempo bom prevaleceriam os transportes para SW, mas sob frontogênese, os transportes para NE seriam predominantes. Essas forças maiores seriam responsáveis pelo deslocamento das zonas de barlamar das células locais de deriva litorânea ao longo das praias.

De maneira geral, os resultados obtidos estão de acordo com as observações de campo em relação à ocorrência de processos erosivos e deposicionais.

A seguinte informação, inusitada, porém interessante, foi fornecida por moradores antigos da área da Estação Ecológica. Por várias vezes, corpos de pessoas que morreram na Barra do Ribeira ou na Juréia, por afogamento durante as tempestades, foram encontrados na Praia do Una-Norte, comprovando a existência de transportes para o norte durante fases de instabilidade meteorológica.

PONÇANO et al. (1994, in NAKAZAWA, et al.,1994) sugerem tendências de transporte semelhantes (figura 3 ) às encontradas aqui. 


\section{3. SETOR MORFODINÂMICO III}

Neste Setor foram estudadas as praias de Peruibe, Itanhaém e Praia Grande.

\section{3. 1. Análise de Produtos de Sensoriamento Remoto}

As fotografias aéreas utilizadas compreendem as obtidas em 1962, 1966 e 1994 (figura 18). Na tabela 6 estão relacionados os dados relativos às medidas de ondas.

Nas praias de Peruibe, Itanhaém e Praia Grande, não foi possivel identificar qualquer tendência geral de transporte a partir das fotos analisadas. Aparentemente, várias células pequenas de deriva litorânea atuam ao longo dessas praias.

Nas imagens de satélite de 1976 e da década de 90 observam-se duas grandes plumas de material em suspensão orientadas para SW, uma a partir da porção central da Praia de Peruíbe, dirigida para o Guaraú, e outra a partir do Rio Itanhaém. A presença da Pedra dos Jesuítas, ocasiona a inflexão dessas correntes para o largo provocando um estreitamento da praia a jusante. Ao longo da Praia de Itanhaém as plumas sugerem transporte para NE a partir do Rio Itanhaém e para SW a partir do Rio Mongaguá que, no seu encontro geram correntes de retorno, aproximadamente no trecho centro-norte da praia. Ao longo da Praia Grande observam-se, na imagem de 1976, plumas orientadas para SW a partir da metade sul e para NE na metade norte da praia. Na imagem da década de 90 há indicações de forte transporte para SW ao longo de toda a praia até Mongaguá. Plumas provenientes da Baía de Santos contornam a Ponta de Itaipu e rumam para a Praia Grande. Estas indicações são diferentes daquelas descritas em SONDOTÉCNICA (1977), que sugeririam transporte para o interior da baia. Este transporte, no entanto, deve tornarse mais efetivo sob condições de ondas de SW-SSW e S-SSE.

Em praticamente todas as fotografias aéreas analisadas notou-se a ocorrência de cúspides praiais ao longo das três praias. O desenvolvimento dessas feições em praias dissipativas de alta energia ainda é muito discutivel. GUZA \& INMAN (1975) atribuem-nas a uma perturbação periódica inicial na topografia de fundo nas proximidades da costa, criada por ondas de ressonância (edge waves), e posterior evolução das cúspides devida à atuação do trem de ondas principal sobre a forma de fundo perturbada. De fato, as ondas observadas nas fotos aéreas (tabela 6) indicam a permanente atuação de um trem de 
ondas principal, gerando transportes para NE e de um trem secundário, responsável pelos transportes para SW, ambos associados a ondas do quadrante SE. A atuação de transportes costa adentro e costa afora parece também efetiva ao longo dessas praias.

\section{3. 2. MÉTODO DE TAGGART \& SCHWARTZ-MODIFICADO}

A figura 19 mostra os resultados obtidos para o setor III a partir da aplicação desse método. $\mathrm{Na}$ tabela 7 são apresentados os dados relativos às medições de ondas no campo.

As figuras 20 e 21 exibem os gráficos de variação da inclinação e da largura dessas praias.

\section{Peruibe}

As características morfológicas da Praia de Peruibe mudaram muito pouco entre o inverno e o verão. De maneira geral, verificou-se aumento progressivo na largura da praia, de sul para norte, embora oscilações sempre ocorram com estreitamentos nos pontos 33/386, 35 e 37. A inclinação da praia mostrou tendências gerais de diminuição de sul para norte. As maiores inclinações foram encontradas ao sul da praia (perfis 33/386, 34/387 e 35).

Nessa praia predominam areias muito finas $(79,2 \%)$ muito bem selecionadas $(86,1 \%)$, seguidas das areias finas $(20,8 \%)$ bem selecionadas $(9,1 \%)$ e moderadamente selecionadas (4,9\%). Em geral, areias relativamente mais grossas ocorrem no setor centrosul da praia, nos pontos 34/387, 35 e 36/388 (Figura 22). Da mesma forma, o grau de seleção é mais baixo neste trecho, aumentando rumo ao norte e ao sul. Pequenas variações desses comportamentos foram observadas entre inverno e verão.

GIANNINI (1987) encontrou resultados semelhantes, identificando as mesmas tendências de variação do diâmetro médio e grau de seleção, sugerindo derivas litorâneas rumo NE.

A "matriz de comparação" (quadro 17) revela que ao longo da Praia de Peruibe, atuam várias pequenas células de deriva litorânea indicando, além disso, as seguintes tendências. 
(a) O extremo sul da praia e o ponto $36 / 388$ constituem zonas de sotamar.

(b) Nos trechos entre os pontos 34/387 e 35 e, 37 e 38/373 ocorrem centros de divergência de duas células de deriva litorânea, cujas zonas de barlamar podem migrar.

(c) Nos pontos 39/372 e 40/371 observou-se a inversão de processos entre o inverno e o verão. Nesse trecho parece ter havido uma inversão no sentido da deriva litorânea, estando a zona de barlamar localizada no local do perfil 39 no inverno, mas migrando para o extremo norte da praia (perfil 371) no verão. O mesmo teria ocorrido no local do perfil $38 / 373$, que passou de zona de sotamar no inverno para barlamar no verão.

Deste modo, tanto no inverno $(53,8 \%)$ quanto no verão $(60 \%)$, o transporte para SW foi levemente predominante sobre o de rumo NE.

Foram feitos testes de comparação apenas entre as amostras 34 e 36,36 e 38 (eliminando-se as amostras 35 e 37 que não possuem correlatas no inverno), e obteve-se as mesmas tendências mostradas no quadro 17 , em relação aos processos predominantes (E ou D).

Quadro 17: Matriz de comparação elaborada para a Praia de Peruíbe

\begin{tabular}{|c|c|c|c|c|c|c|c|c|c|}
\hline & \multicolumn{3}{|c|}{ PARÂM. TEXTURAIS } & \multicolumn{2}{|c|}{ MORFOLOGIA } & \multirow[b]{2}{*}{$\begin{array}{l}\text { Resultado } \\
\text { Final }\end{array}$} & \multirow[b]{2}{*}{$\begin{array}{c}\text { PROCESSO } \\
E=\text { =rosão } \\
D=\text { deposição } \\
T=\text { transporte }\end{array}$} & \multirow[b]{2}{*}{$\begin{array}{c}\text { SENTIDO } \\
\text { DA } \\
\text { DERIVA }\end{array}$} \\
\hline $\begin{array}{l}\text { Etapa } \\
\text { de } \\
\text { Amost }\end{array}$ & $\begin{array}{l}\text { Perfil } \\
\text { Praial }\end{array}$ & $\begin{array}{l}\text { Diâmetro } \\
\text { Médio }\end{array}$ & $\begin{array}{c}\text { Grau } \\
\text { de } \\
\text { Seleção }\end{array}$ & $\begin{array}{c}\text { Curto- } \\
\text { se }\end{array}$ & $\begin{array}{l}\text { Incli- } \\
\text { nação }\end{array}$ & $\begin{array}{l}\text { Largu- } \\
\text { ra }\end{array}$ & & & \\
\hline \multirow{8}{*}{$\begin{array}{c}\mathrm{I} \\
\mathrm{N} \\
\mathrm{V} \\
\mathrm{E} \\
\mathrm{R} \\
\mathrm{N} \\
\mathrm{O}\end{array}$} & 33 & + & + & + & + & - & + & $\mathrm{D}$ & SW \\
\hline & 34 & $-1+$ & $-1 / 4$ & $-1-$ & $-1-$ & $+1+$ & $-1+$ & $T$ & SW \\
\hline & 35 & $-1-$ & $-1-$ & $+1-$ & +10 & $-1-$ & $-1-$ & $\mathrm{E}$ & SW/NE \\
\hline & 36 & $+1-$ & $+1+$ & $+/+$ & $0 /-$ & $+/+$ & $+/+$ & $\overline{\mathrm{D}}$ & $\mathrm{NE} / \mathrm{SW}$ \\
\hline & 37 & $+1-$ & $-1-$ & $-1-$ & $+/ 0$ & $-1-$ & $-1-$ & $\mathrm{E}$ & SW/NE \\
\hline & 38 & $+1+$ & $+1+$ & $+1+$ & $0 / 0$ & $t+$ & $t / t$ & $\mathrm{D}$ & NE/SW \\
\hline & 39 & $-1+$ & $-i-$ & $-1-$ & $0 / \omega$ & $-1-$ & $-1 m$ & $\mathrm{E}$ & SW/NE \\
\hline & 40 & - & - & + & + & + & + & $\mathrm{D}$ & NE \\
\hline \multirow{6}{*}{$\begin{array}{l}\mathrm{V} \\
\mathrm{E} \\
\mathrm{R} \\
\tilde{\mathrm{A}} \\
\mathrm{O}\end{array}$} & 386 & + & + & + & - & - & + & $\mathrm{D}$ & $\mathrm{SW}$ \\
\hline & 387 & $-1+$ & -- & $-1 / m$ & $+1-$ & $+1-$ & $-1-$ & $\mathrm{E}$ & SW/NE \\
\hline & 388 & $-1-$ & $+1+$ & $+/+$ & $+/ t$ & $+/+$ & $+1+$ & $\mathrm{D}$ & $\mathrm{NE} / \mathrm{SW}$ \\
\hline & 373 & $+1-$ & $-i-$ & $-1-$ & $-1+$ & $-1-$ & $-1-$ & $\mathrm{E}$ & SW/NE \\
\hline & 372 & $+1+$ & $+i+$ & $+1-$ & $-1-$ & $+1+$ & $+/+$ & $\mathrm{D}$ & $\mathrm{NE} / \mathrm{SW}$ \\
\hline & 371 & - & - & + & + & - & - & $\mathrm{E}$ & SW \\
\hline
\end{tabular}


Analisando os rumos das correntes, obtidos através das medidas de onda no campo (tabela 7), verifica-se que o transporte em condições de tempo instável de inverno (final de frente fria) ocorreu somente para SW (100\%). Por outro lado, em condiçōes de tempo bom durante o verão, as frequeências de transporte nos dois sentidos foram iguais. No inverno, o rumo médio encontrado para ondas foi de S62E. No verão, os rumos médios obtidos para as ondas geradoras de transportes para SW e para NE foram de S45E e S35E, respectivamente. Presume-se, então, que mesmo durante o tempo instável de inverno, as ondas já exibiam características de tempo bom.

\section{- Itanhaém}

A morfologia desta praia praticamente não variou entre as duas etapas de amostragem, exceto pelo fato de que a sua largura oscilou ao longo da praia. De maneira geral, as larguras aumentaram a partir dos extremos da praia rumo ao ponto $75 / 367$. As menores larguras ocorrem no extremo sul, próximo ao Rio Itanhaém (perfil 70/370), onde também ocorrem as maiores inclinações. Os perfis de verão mostraram-se, em média, mais inclinados mais largos que no inverno. Isto poderia ser explicado pelas diferenças nas condições meteorológicas e de maré entre as duas etapas, isto é, no inverno o tempo era instável (final de frente fria que atuou por vários dias) e a fase de maré era de sizígia, enquanto no verão o tempo estava bom havia muitos dias e a fase era de maré de quadratura. Portanto, os perfis de inverno se encontravam mais aplainados e erodidos que no verão, quando a calmaria propiciou maior acumulação de areia na praia.

Nesta praia predominam areias muito finas $(83,3 \%)$ e muito bem selecionadas $(69,5 \%)$, seguidas de areias finas $(16,7 \%)$ e bem $(19,4 \%)$ e moderadamente selecionadas $(11,1 \%)$ (figura 23). As areias finas e moderadamente selecionadas são encontradas ao sul da praia (ponto 70/370), podendo ser atribuidas à origem fluvial. O grau de seleção aumenta, progressivamente, deste ponto até o setor norte da praia, mas o diâmetro médio das areias muito finas varia relativamente pouco ao longo da praia.

A "matriz de comparação" (quadro 18) mostra tendências diferentes entre o inverno e o verão, mas a atuação de duas grandes células de transporte fica também evidente pelas seguintes razões: 
(a) O perfil 70/370, no extremo sul da praia, mostrou-se erosivo nas duas etapas de amostragem. A predominância de processos erosivos nesta área foi facilmente observada no campo pela destruição de muros e casas (vide capítulo VII).

(b) No inverno duas grandes células de transporte por deriva litorânea foram reconhecidas, com barlamares localizados nos extremos da praia e a zona de convergência (sotamar) no ponto 75 .

Quadro 18: Matriz de comparação elaborada para a Praia de Itanhaém

\begin{tabular}{|c|c|c|c|c|c|c|c|c|c|}
\hline \multirow{2}{*}{$\begin{array}{c}\text { Etapa } \\
\text { de } \\
\text { Amost }\end{array}$} & \multirow[b]{2}{*}{$\begin{array}{l}\text { Perfil } \\
\text { Praial }\end{array}$} & \multicolumn{3}{|c|}{ PARÁM. TEXTURAIS } & \multicolumn{2}{|c|}{ MORFOLOGIA } & \multirow[b]{2}{*}{$\begin{array}{c}\text { Resultado } \\
\text { Final }\end{array}$} & \multirow[b]{2}{*}{$\begin{array}{c}\text { PROCESSO } \\
\mathrm{E}=\text { erosão } \\
\mathrm{D}=\text { deposição } \\
\mathrm{T}=\text { transporte }\end{array}$} & \multirow[b]{2}{*}{$\begin{array}{c}\text { SENTIDO } \\
\text { DA } \\
\text { DERIVA }\end{array}$} \\
\hline & & $\begin{array}{l}\text { Diâmetro } \\
\text { Médio }\end{array}$ & \begin{tabular}{|c} 
Grau \\
de \\
Seleção
\end{tabular} & $\begin{array}{l}\text { Curto- } \\
\text { se }\end{array}$ & $\begin{array}{l}\text { Incli- } \\
\text { nação }\end{array}$ & $\begin{array}{l}\text { Largu- } \\
\text { ra }\end{array}$ & & & \\
\hline \multirow{6}{*}{ INV. } & 70 & - & - & + & - & - & - & $\mathrm{E}$ & $\mathrm{NE}$ \\
\hline & 72 & $+1-$ & $+1-$ & $-1+$ & $+/+$ & $+1-$ & $+1-$ & $T$ & $\mathrm{NE}$ \\
\hline & 73 & $+1-$ & $+/-$ & $-1-$ & $-/ 0$ & $+1-$ & $+1-$ & $T$ & $\mathrm{NE}$ \\
\hline & 75 & $+/ t$ & $+/-$ & $t / t$ & $0 /+$ & $+1+$ & $t / t$ & $\mathrm{D}$ & $\mathrm{NE} / \mathrm{SW}$ \\
\hline & 76 & $-1+$ & $+1-$ & $-1 /+$ & $-1+$ & $-1+$ & $-1+$ & $\bar{T}$ & SW \\
\hline & 77 & - & + & - & - & - & - & E & SW \\
\hline \multirow{6}{*}{ VER. } & 370 & - & - & + & - & - & - & $\mathrm{E}$ & $\mathrm{NE}$ \\
\hline & 369 & $+/+$ & $+1+$ & $-1-$ & $t / t$ & $+/+$ & $+1+$ & $\overline{\mathrm{D}}$ & $\mathrm{NE} / \mathrm{SW}$ \\
\hline & 368 & $-1+$ & $-1-$ & $+1+$ & $-1-$ & $-1-$ & $-1-$ & E & SW/NE \\
\hline & 367 & $-1 / m$ & $+1-$ & $-1-$ & $+1-$ & $+/+$ & $+1-$ & $T$ & $\mathrm{NE}$ \\
\hline & 366 & $+/+$ & $+1-$ & $+1-$ & $+1-$ & $-1-$ & $+1-$ & $T$ & $\mathrm{NE}$ \\
\hline & 365 & - & + & + & + & + & + & $\mathrm{D}$ & $\mathrm{NE}$ \\
\hline
\end{tabular}

(c) No verão, por outro lado, encontrou-se uma zona de divergência de células na porção central da praia (ponto 368), com sotamares no extremo norte (perfil 365) e no ponto 369,0 qual também corresponde ao sotamar de uma célula menor proveniente do extremo sul.

(d) Em ambas as etapas de amostragem predominaram transportes de rumo NE, com freqüências de $57,1 \%$ no inverno e $75 \%$ no verão.

Os resultados obtidos com as medidas de ortogonais de ondas no campo (tabela 7), entretanto, indicam transportes apenas para NE no inverno (100\%), e somente para SW no verão $(100 \%)$. Os rumos médios de ondas associadas aos transportes NE e SW foram de S23E e S50E, respectivamente. Portanto, sob as condições de instabilidade do inverno, as ondas ainda guardavam características de frente fria. 


\section{- Praia Grande}

Na Praia Grande as larguras da praia mostraram-se bem maiores no verão, com diferenças de até $71 \mathrm{~m}$ entre as duas etapas de amostragem. Essas diferenças devem-se ao fato de que no inverno os trabalhos foram efetuados em preamar de sizígia, enquanto no verão foram em baixamar de sizígia. Além disso, no inverno a área encontrava-se sob o efeito da fase final de uma frente fria, enquanto no verão atuavam condições de tempo bom. As menores larguras foram encontradas no extremo sul da praia (perfil 59/345), onde também estavam as maiores inclinações. Foi verificada uma tendência geral de aumento de largura e diminuição de inclinação rumo ao setor norte da praia.

$\mathrm{Na}$ Praia Grande predominam areias finas (75\%) e muito bem selecionadas (100\%), seguidas das areias muito finas $(25 \%)$. No entanto, do inverno para o verão, observou-se um afinamento das areias, pois no inverno havia $83,3 \%$ de areias finas e $16,7 \%$ de areias muito finas, enquanto no verão, as areias muito finas passaram a perfazer $66,7 \%$ e as areias finas apenas $33,3 \%$ (figura 24). Mas este afinamento ocorreu principaimente no setor norte da praia (pontos 349 e 350). De maneira geral, verificou-se uma tendência à diminuição no tamanho das areias e ligeiro aumento no grau de seleção de sul para norte.

A "matriz de comparação" (quadro 19) mostrou a predominância de transporte para NE ao longo de toda a praia, com freqüências de $75 \%$ no inverno e $71,4 \%$ no verão. No entanto, uma pequena célula de sentido oposto foi encontrada nas duas etapas, embora com barlamares deslocados, isto é, situado no ponto 56 durante o inverno e no extremo norte da praia durante o verão (ponto 350). Nas duas etapas de amostragem o extremo sul da praia comportou-se como zona de barlamar de grandes células de rumo NE.

As medidas de ortogonais de ondas efetuadas no campo (tabela 7) mostraram predominância de transportes no sentido contrário ao do quadro 19 . Cerca de $100 \%$ das medidas de inverno e $83,3 \%$ das de verão indicaram transportes para SW (rumo a Itanhaém), associados a ondas de S47E (valor médio). Isto significa que na época da amostragem do inverno as condições de ondas de frente fria já haviam cessado. 
Quadro 19: Matriz de comparação elaborada para a Praia Grande

\begin{tabular}{|c|c|c|c|c|c|c|c|c|c|}
\hline & \multicolumn{3}{|c|}{ PARAMM. TEXTURAIS } & \multicolumn{2}{|c|}{ MORFOLOGIA } & \multirow[b]{2}{*}{$\begin{array}{c}\text { Resultado } \\
\text { Final }\end{array}$} & \multirow[b]{2}{*}{$\begin{array}{c}\text { PROCESSO } \\
\text { E=erosão } \\
\mathrm{D}=\text { deposição } \\
\mathrm{T}=\text { transporte }\end{array}$} & \multirow[b]{2}{*}{$\begin{array}{c}\text { SENTIDO } \\
\text { DA } \\
\text { DERIVA }\end{array}$} \\
\hline $\begin{array}{c}\text { Etapa } \\
\text { de } \\
\text { Amost }\end{array}$ & $\begin{array}{l}\text { Perfil } \\
\text { Praial }\end{array}$ & $\begin{array}{c}\text { Diâmetro } \\
\text { Médio }\end{array}$ & $\begin{array}{c}\text { Grau } \\
\text { de } \\
\text { Seleção }\end{array}$ & $\begin{array}{c}\text { Curto- } \\
\text { se }\end{array}$ & $\begin{array}{l}\text { Incli- } \\
\text { nação }\end{array}$ & $\begin{array}{l}\text { Largu- } \\
\text { ra }\end{array}$ & & & \\
\hline \multirow{6}{*}{ INV. } & 59 & + & + & - & - & - & - & $\mathrm{E}$ & $\mathrm{NE}$ \\
\hline & 58 & $-1-$ & $-1-$ & $+1-$ & $+1+$ & $+1-$ & $+1-$ & $\mathrm{T}$ & $\mathrm{NE}$ \\
\hline & 57 & $+1-$ & $+/ t$ & $+/ t$ & $-1-$ & $+1+$ & $+1+$ & $\bar{D}$ & NE/SW \\
\hline & 56 & $+/+$ & $-1-$ & $-1-$ & $+1-$ & $-1-$ & $-1-$ & $\mathrm{E}$ & SW/NE \\
\hline & 55 & $-1-$ & $+1-$ & $+1-$ & $+1-$ & $+1+$ & $+1-$ & $\mathrm{T}$ & $\mathrm{NE}$ \\
\hline & 54 & + & + & - & + & - & + & $\bar{D}$ & $\mathrm{NE}$ \\
\hline \multirow{6}{*}{ VER. } & 345 & + & - & - & - & - & - & $\mathrm{E}$ & $\mathrm{NE}$ \\
\hline & 346 & $-1-$ & $+1-$ & $t / t$ & $+1-$ & $+1-$ & $+1-$ & $\mathrm{T}$ & $\mathrm{NE}$ \\
\hline & 347 & $+1+$ & $+/-$ & $-1-$ & $+1-$ & $t / t$ & $+1-$ & $T$ & $\mathrm{NE}$ \\
\hline & 348 & $-1-$ & $+1-$ & $+/ t$ & $+1+$ & $-1-$ & $+1-$ & $\mathrm{T}$ & $\mathrm{NE}$ \\
\hline & 349 & $+1-$ & $+1-$ & $-1+$ & $-1+$ & $+/ t$ & $+/ 4$ & $\mathrm{D}$ & $\mathrm{NE} / \mathrm{SW}$ \\
\hline & 350 & + & + & - & - & - & - & $\mathrm{E}$ & SW \\
\hline
\end{tabular}

\section{3. 3. MÉTOdO DE MCLAREN}

Os quadros 20 e 21 (Volume II) mostram os resultados obtidos pela aplicação desse método, a partir dos quais pôde-se chegar às tendências descritas a seguir.

(a) Os casos positivos perfizeram $31,4 \%$ do total de correlações no inverno e $24,3 \%$ no verão.

(b) Para ambas as etapas verificou-se ligeira predominância de transporte para NE, com cerca de $55,4 \%$ no inverno $(Z$ - estatístico $=8,99$ ) e $58,4 \%$ no verão ( $Z$ - estatístico $=6,34$ ).

(c) Entretanto, o transporte para SW também atingiu altas porcentagens com cerca de $44,6 \%$ no inverno (Z- estatístico $=6,20$ ) e $41,6 \%$ no verão $(Z$ - estatístico $=3,16$ ).

(d) No inverno predominaram os casos $\mathrm{B}$, com freqüência de $70,3 \%$, atingindo nivel de significância apenas os casos $B$ para SW $(Z$ - estatístico $=2,91)$. Os casos $C$ para NE também atingiram nivel de significância alto ( $Z$ - estatístico $=2,42$ ).

(e) Os casos B ficaram predominantemente associados aos transportes para SW, enquanto que os casos $C$ praticamente só ocorreram relacionados aos transportes NE. Isso sugere que esses rumos são representativos de energia mais alta. 
(f) Os pontos de amostragem 70/370 e 72 mostraram-se erosivos, sendo fontes para a maioria dos demais, porém sem contribuição de fontes locais.

(g) A Praia de Itanhaém mostrou-se, em geral, mais erosiva que as de Peruibe e Praia Grande, sendo fonte dessas praias, porém com poucas fontes locais. Portanto, aparentemente, a maior parte do transporte para SW inicia-se nesta praia.

(h) O transporte para NE ficou bem evidenciado entre as praias de Peruibe e Praia Grande, sendo a primeira fonte da segunda.

\section{3. 4. CONCLUSÕES}

No setor III atua, predominantemente, transporte no sentido NE, embora ocorram simultaneamente várias células locais de sentidos opostos.

O quadro 22 mostra um resumo dos resultados de rumos obtidos com os três métodos aplicados. As ortogonais de ondas medidas nas fotografias aéreas de 1962 não foram computadas devido ao desconhecimento da data exata do sobrevôo.

Quadro 22. Comparação entre os resultados percentuais dos rumos de transporte obtidos a partir de diferentes métodos utilizados.

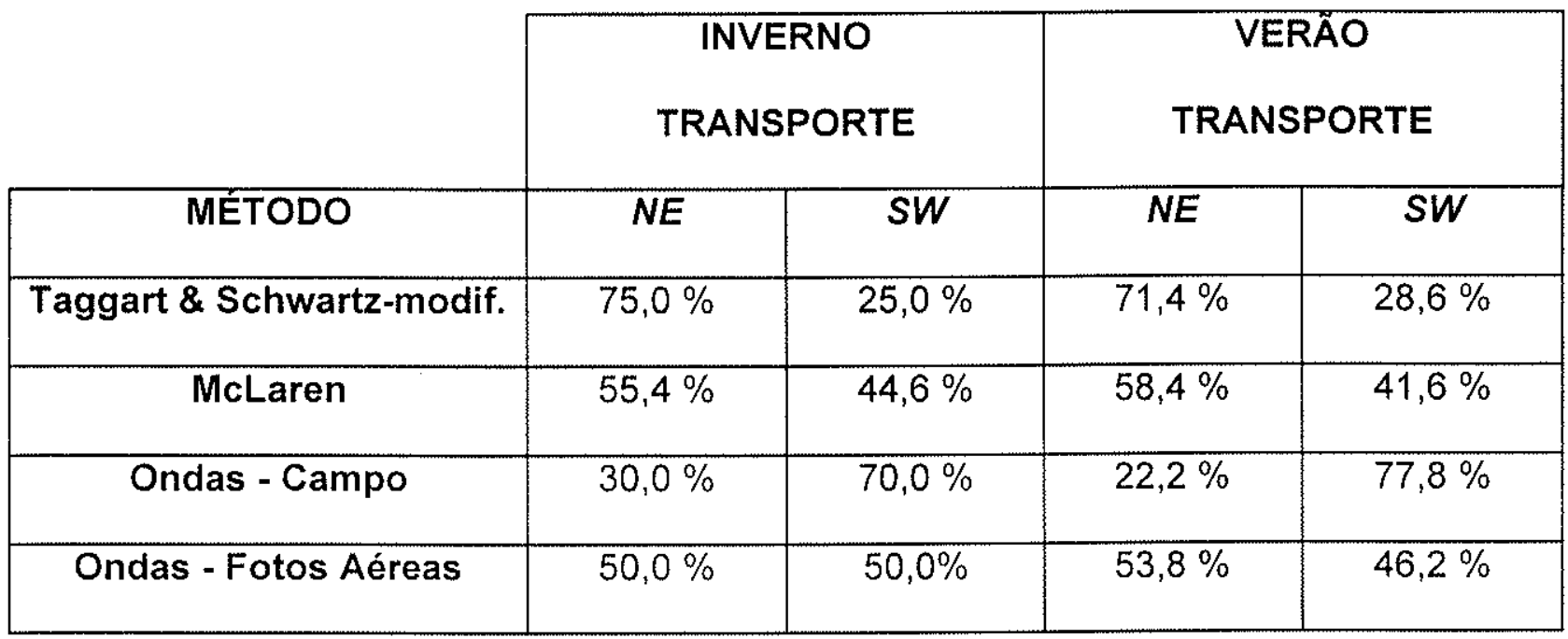

As ortogonais de ondas medidas no campo mostraram predominância de transportes para SW nas duas etapas de amostragem. No inverno, 100\% das medidas de ondas feitas estão associados a tempo instável e no verão, $100 \%$ se referem a medidas em 
condições de tempo bom. Isso significa que, em condições de instabilidade, as ondas e correntes atuavam semelhantemente às de tempo bom, isto é, propagando-se de SE, com altos ângulos, exceto na Praia de Itanhaém, onde prevaleceram ondas indicativas de transportes NE, com propagação de SE com baixos ângulos. Por outro lado, os dados obtido nas fotografias aéreas mostraram freqüências muito semelhantes de transportes para NE e para SW, com ligeira predominância do primeiro. Na realidade, dois trens de ondas sempre estavam presentes, um principal, com cristas arredondadas e regulares, e incidência bem definida, e um secundário, com características opostas. O transporte para NE sempre estava ligado ao trem de ondas principal em todas as praias, com ângulo de incidência médio de S36E na Praia de Peruíbe, S28E na Itanhaém, e S26E na Praia Grande. Essas ondas parecem estar relacionadas a condições pré-frontais. Os rumos SW, que podem estar associados a ondas de ressonância (edge waves), eram gerados por trens com valores médios de S63E em Peruíbe, S64E em Itanhaém, e S60E em Praia Grande.

As caracteristicas de ondas, descritas acima, são provavelmente as responsáveis pelo freqüente desenvolvimento de cúspides nessas praias.

Os resultados obtidos a partir do método de MCLAREN mostram tendências quase equivalentes de transportes os dois sentidos, indicando que ambos são igualmente importantes nessas praias.

Comparando os resultados obtidos pelo método de TAGGART \& SCHWARTZmodificado e a partir das medidas de ondas no campo nota-se uma inversão, predominando o transporte para NE no primeiro e para SW no segundo. Como foi dito anteriormente, no inverno atuavam condições meteorológicas instáveis, mas com características de ondas de tempo bom para Peruibe e Praia Grande e frente fria para Itanhaém e, no verão, o tempo estava bom, com calmaria. Isto poderia significar que as condições sob as quais os depósitos (exceto no inverno em Peruibe e em Itanhaém) se formaram eram adversas daquelas reinantes nas etapas de amostragem.

As interpretações de BOMTEMPO (1991) para a região ao sul (setor II), sugerindo a predominância de rumos para SW durante as calmarias e de NE em condições de préfrontais e frontais, poderiam ser válidas também para este setor, pois as linhas de costa de ambos setores têm orientações gerais quase iguais, de N54E no setor II e N58E no setor 11I. Portanto, a maioria das amostras coletadas nas praias de Itanhaém e Praia Grande 
seria representativa de episódios deposicionais associados à passagem de sistemas frontais ocorridos anteriormente às etapas de coleta. Não obstante, se isso for real, então apenas os eventos mais rigorosos estariam deixando seus registros sedimentares nessas praias, ou então, principalmente no caso de verão, as praias ainda não haviam retomado o seu perfil normal sob condições de calmaria.

Outro fato que também pode ter interferido nos resultados obtidos a partir do comportamento morfotextural dessas praias, é a operação de limpeza das mesmas. Essa operação, em geral efetuada nessas praias durante as épocas de férias, é feita com tratores que removem as camadas superficiais de areia (vide capítulo VII). Então, por exemplo, no verão os sedimentos depositados durante o longo periodo de calmaria poderiam ter sido removidos, restando os depósitos de outras épocas.

Finalmente, alguns aspectos sobre a circulação costeira nessas praias podem ser ressaltados, os quais evidenciam também boa correlação com os processos erosivos e deposicionais observados no campo.

(a) $\mathrm{Na}$ Praia de Peruíbe as células foram melhor caracterizadas, com zonas predominantemente deposicionais nas margens do Rio Preto, explicando provavelmente a relativa estabilidade da obra do enrocamento, e nas proximidades dos perfis $36 / 388$ e $38 / 373$, esta última associada à zona de sombra da Pedra dos Jesuítas. Centros de divergência de células ocorrem predominantemente entre os pontos $34 / 387$ e 35 , e $39 / 372$ e 40/371. Processos erosivos foram observados no campo nesses locais (foto 6 )

(b) Na Praia de Itanhaém parece predominar o transporte para NE, ao longo de toda a sua extensão. No setor sul, principalmente entre os pontos $70 / 370$ e $72 / 369$, ocorrem fortes processos erosivos, bem caracterizados por todos os métodos. CAZZOLI (1996), realizando um monitoramento mensal na Praia de Itanhaém, entre abril de 1994 e maio de 1995, também concluiu haver predominância de processos erosivos no trecho sul desta praia. O Rio Itanhaém tem sua desembocadura, em geral, deslocada para NE, aparentemente por correntes provenientes de sul (Peruibe), que são defletidas para o largo pela presença de pequenos pontões de embasamento e pela força dos fluxos que saem do continente. A continüidade deste transporte para norte, associada à ocupação marginal da praia, é responsável pela predominância do processo erosivo no local. Os amplos transportes para NE podem ser interrompidos por pequenas células locais com sentido oposto, como na área próxima à plataforma de pesca (ponto 75/367). Na margem direita da 
desembocadura do Rio Mongaguá, adotado aqui como limite norte da Praia de Itanhaém, ocorrem processos mistos (deposicionais e erosivos) associados à dinâmica mais ampla de deriva litorânea e a pequenas células geradas nas proximidades do espigão. Transportes costa adentro e costa afora também podem ocorrer nesta praia.

(c) Na margem esquerda do Rio Mongaguá, adotado aqui como limite sul da Praia Grande, predominam processos erosivos, bem caracterizados por todos os métodos e também observado no campo. Predomina o transporte para NE ao longo de toda a praia, podendo ser interrompido por pequenas células locais de sentido oposto. Transportes costa adentro e costa afora também podem ocorrer nessa praia.

GIANNINI (1987) sugeriu correntes de deriva litorânea com sentido predominantemente NE para a Praia de Peruibe. PONÇANO et al. (1994, in NAKAZAWA, et al., 1994) apontaram a predominância de transportes costa adentro-costa afora para todo este setor e marcaram apenas um local onde atuaria corrente para NE (figura 3).

\section{4. SETOR MORFODINÂMICO IV}

As praias estudadas neste setor foram: São Vicente, Itararé, Santos, Guaiúba, Tombo, Astúrias, Pitangueiras, Enseada, Pernambuco e Mar Casado, Perequê, São Pedro e Iporanga.

\section{4. 1. Análise de Produtos de Sensoriamento Remoto}

A figura 25 mostra os resultados obtidos para este setor a partir das interpretações de quatro conjuntos de fotografias aéreas obtidas em 1962, 1966, 1972 e 1994 (quadro 3). $\mathrm{Na}$ tabela 8 encontram-se os dados relativos às medições de ortogonais de ondas efetuadas nessas fotos. De maneira geral, os resultados revelam excelente correlação entre todos os vôos.

Na Praia de São Vicente, o transporte para $W$ é facilmente identificado pela morfologia da linha de costa segmentada por cinco espigões, cada um deles exibindo forte 
progradação na face leste e retrogradação na face oeste. No extremo SSE da praia as derivas são dirigidas para o tômbolo da llha Porchat e depois para o largo.

Na Praia de Itararé observou-se duas células divergentes a partir da porção central da praia, que também é o trecho mais aberto para o mar. Correntes dirigidas para os extremos leste (Ilha Urubuqueçaba - com grande cúspide ou tômbolo) e oeste (Ilha Porchat - com tômbolo) da praia sempre ocorrem. Ondas de rumo médio S24E são as responsáveis pelo transporte para W, e ondas de S45W (única medida) geram as correntes para $\mathrm{E}$.

Ao longo da Praia de Santos foram observadas duas grandes células divergentes a partir do setor centro-leste. A corrente E vai até a boca do Canal do Porto. A de rumo oeste segue no rumo à Ilha Urubuqueçaba, e depois segue para o largo. Com a construção do longo espigão do emissário de Santos-São Vicente (visto nas fotografias aéreas de 1994), entre o Canal 1 e a Ilha Urubuqueçaba, esta corrente fica bloqueada, desviando-se para o largo logo após o Canal 1 (foto 8a). Pequenas células de deriva litorânea se formam entre os seis canais que segmentam a Praia de Santos. Grande plumas de material em suspensão são dirigidas para oeste ao longo desta praia, depois se defletem para o largo da Baía de Santos. Parte segue para a Praia Grande a SSW e parte ruma para SSE até a borda sudoeste da Ilha de Santo Amaro. Ondas de rumo médio S06E junto à praia e S30E no largo da Baía de Santos são responsáveis pelas derivas para W. Ondas secundárias de S46W geram correntes com sentido oposto.

Nas imagens de satélite de 1976 e da década de 90 podem ser visualizadas as mesmas tendências descritas para as praias da Baía de Santos.

Na Praia do Guaiúba observa-se uma célula de rumo SE.

Nas praias do Tombo e Astúrias ocorrem duas células divergentes a partir da porção central. Ondas com rumos médios S29E (trem principal) e S52E (trem secundário) geram, respectivamente, correntes para NE e SW na Praia do Tombo.

Em Pitangueiras várias pequenas células parecem ocorrer. Na zona de sombra da Ilha da Pombeva há desenvolvimento de um amplo tômbolo, indicando convergência de duas células de deriva litorânea, cujas zonas de barlamar provocam fortes embaíamentos na praia. Transportes rumo aos extremos da praia também são observados. Ondas com rumos médios S24E (trem principal) e S63E (trem secundário) geram, respectivamente, correntes para NE e SW. 
Embora várias células tenham sido identificadas ao longo da Praia da Enseada, parece predominar o transporte para SW, bem caracterizado também nas imagens de satélite. A incidência das ondas (rumo médio de S44E) formando altos ângulos com a linha de costa também sugere a atuação deste transporte. Ondas de S18E (média) são responsáveis por correntes para NE.

Nas demais praias ao longo da llha de Santo Amaro (Pernambuco/Mar Casado, Perequê, São Pedro e (poranga), foram identificadas duas células divergentes a partir da porção central de cada uma delas.

Plumas de sedimentos em suspensão, observadas principalmente nas fotografias aéreas e imagens de satélite, indicam que a partir da área próxima à Ponta da Galhetas (sul da Praia das Astúrias) ocorrem ampios transportes para SSW rumo à Ponta da Munduba e para ENE rumo à Praia da Enseada. Ao norte desta praia este transporte regional aponta para NE, rumo à Bertioga. Essas orientações estão de pleno acordo com os resultados obtidos através medições de correntes (injeção de materiais radioativos) nas águas litorâneas do Guarujá, efetuadas sob diferentes condições meteorológicas (HIDROCONSULT, 1974/1975).

\section{4. 2. MÉTODO DE TAGGART \& SCHWARTZ-MODIFICADO}

A figura 26 mostra os resultados obtidos com a aplicação deste método para o setor IV. Os dados relativos às ondas medidas no campo estão na tabela 9.

As figuras $27 a, 27 b, 28 a$ e $28 b$ mostram os gráficos de largura e inclinação das praias deste setor.

\section{- São Vicente, Itararé e Santos}

Essas três praias foram analisadas conjuntamente, pois encontram-se no interior da Baía de Santos e, portanto, sujeitas às mesmas condições oceanográficas.

As larguras são homogêneas ao longo dessas praias, mas mostraram-se bem maiores durante o verão. Isto se deve ao fato de que, no inverno, as amostragens foram feitas durante a passagem de uma frente fria de forte intensidade, somada à maré de sizígia. No verão, também em maré de sizigia, as condições de tempo eram boas, com 
calmaria. As inclinações da antepraia e da face litorânea não seguiram as mesmas variaçōes, ficando os valores muito próximos. Isto deve ser esperado em praias dissipativas de baixa energia como essas, que têm declividades muito baixas no largo. As menores larguras foram encontradas nos dois extremos da área, na Praia de São Vicente e no canto leste da Praia de Santos, neste último porque também está sob a influência das correntes do Canal do Porto. Rumo ao centro da Baía de Santos (ponto 81/354), na Praia do Itararé, as larguras aumentam bastante. Isso ocorre devido à difração das ondas na llha Urubuqueçaba e devido ao grande espigão do emissário de Santos-São Vicente (fotos 8 a e 8b). As inclinações da antepraia são maiores na Praia de São Vicente e menores em Santos. Isso ocorre porque a primeira é abrigada das ondas mais enérgicas provenientes de SSW-S-SSE (frentes frias), enquanto Santos as recebe frontalmente.

Dados do INPH (HIDROCONSULT, 1975/1975) indicam que as ondas que atingem a Baía de Santos propagam-se nos rumos entre S60E e S20W, com 50\% do registros entre S50E e NS. Nos meses de verão as ondas que chegam à bala se propagam de SE para NW, em virtude da influência da brisa marítima, mas no inverno se propagam mais freqüentemente de SW para NE pela maior influência das frentes frias.

$\mathrm{Na}$ figura 29 encontram-se os gráficos dos parâmetros texturais para essas praias. Na Praia de São Vicente as areias são finas (100\%) e muito bem selecionadas $(100 \%)$. Em Itararé predominam areias finas $(58,3 \%)$ e bem selecionadas $(66,7 \%)$, seguidas das areias muito finas $(41,7 \%)$ e muito bem selecionadas $(33,3 \%)$. Na Praia de Santos as areias são finas $(50 \%)$ e médias $(50 \%)$, muito bem $(66,7 \%)$ e bem selecionadas $(22,2 \%)$. Percebe-se, portanto, que há uma tendência geral de afinamento das areias e melhora no grau de seleção de Santos para São Vicente, sugerindo derivas litorâneas resultantes de leste para oeste e, também, transferências de sedimentos de Santos para São Vicente.

Mas o comportamento textural dessas praias variou entre as etapas, havendo afinamento das areias e melhora no grau de seleção, do inverno para o verão. No inverno, $42,9 \%$ das areias eram médias e $57,1 \%$ eram finas, com $38,1 \%$ muito bem selecionadas, $47,6 \%$ de bem selecionadas e $14,3 \%$ moderadamente selecionadas. No verão, as areias finas passaram a $71,4 \%$, as médias a $23,8 \%$, e apareceram as areias muito finas, com $4,8 \%$. Os termos muito bem selecionados cresceram para $47,6 \%$ e os moderadamente selecionados diminuiram para $4,8 \%$, ficando os bem selecionados constantes $(47,6 \%)$. 
Através da "matriz de comparação" (quadro 23), percebe-se que na Praia de São Vicente as tendências foram erosivas no inverno e deposicionais no verão. Na Praia de Itararé foram reconhecidas, no inverno, duas células divergentes na porção central, com sotamar nas extremidades da praia. No verão, porém, apenas uma única e completa célula de rumo $E$ foi encontrada, com barlamar no extremo oeste. Na Praia de Santos, em ambas etapas de amostragem, foi identificada uma célula completa com barlamar no ponto 82/355 e sotamar na Ponta da Praia (extremo leste). Entre as praias de Santos e Itararé, nas duas etapas, foi identificado um intercâmbio de sedimentos da primeira para a segunda, com zona de barlamar no ponto $82 / 355$ e deposição no extremo leste de Itararé (ponto 81/354). Portanto, transportes para $W$ também ocorrem na Praia de Santos.

Quadro 23: Matriz de comparação elaborada para as praias de São Vicente, Itararé e Santos

\begin{tabular}{|c|c|c|c|c|c|c|c|c|c|}
\hline \multirow[b]{2}{*}{$\begin{array}{c}\text { Etapa } \\
\text { de } \\
\text { Amost }\end{array}$} & \multirow[b]{2}{*}{$\begin{array}{l}\text { Perfil } \\
\text { Praial }\end{array}$} & \multicolumn{3}{|c|}{ PARÁM. TEXTURAIS } & \multicolumn{2}{|c|}{ MORFOLOGIA } & \multirow[b]{2}{*}{$\begin{array}{c}\text { Resultado } \\
\text { Final }\end{array}$} & \multirow[b]{2}{*}{\begin{tabular}{|c|} 
PROCESSO \\
$\mathrm{E}=$ erosão \\
$\mathrm{D}=$ deposiçăo \\
$\mathrm{T}=$ transporte \\
\end{tabular}} & \multirow[b]{2}{*}{$\begin{array}{c}\text { SENTIDO } \\
\text { DA } \\
\text { DERIVA }\end{array}$} \\
\hline & & $\begin{array}{l}\text { Diâmetro } \\
\text { Médio }\end{array}$ & $\begin{array}{c}\text { Grau } \\
\text { de } \\
\text { Seleção }\end{array}$ & $\begin{array}{c}\text { Curto- } \\
\text { se }\end{array}$ & $\begin{array}{l}\text { Incli- } \\
\text { nação }\end{array}$ & $\begin{array}{l}\text { Largu- } \\
\text { ra }\end{array}$ & & & \\
\hline \multirow{7}{*}{$\begin{array}{l}\mathrm{I} \\
\mathrm{N} \\
\mathrm{V} \\
\mathrm{E} \\
\mathrm{R} \\
\mathrm{N} \\
\mathrm{O}\end{array}$} & 78 & + & + & - & - & - & - & $\mathrm{E}$ & $\mathrm{W} / \mathrm{E}$ \\
\hline & 79 & $-1+$ & $-1+$ & $+1+$ & $+1-$ & $+1-$ & $+1+$ & $\mathrm{D}$ & W/E \\
\hline & 80 & $-1-$ & $-1-$ & $-1-$ & $+/+$ & $+1-$ & $-1-$ & $E$ & $\mathrm{E} / \mathrm{W}$ \\
\hline & 81 & $+1+$ & $+1+$ & $+/+$ & $-1-$ & $+/+$ & $+/ t$ & $\mathrm{D}$ & W/E \\
\hline & 82 & $-1+$ & $-1-$ & $-1-$ & $+1-$ & $-/+$ & $-1-$ & $E$ & $\mathrm{~W} / \mathrm{E}$ \\
\hline & 83 & $-1-$ & $+1+$ & $+1-$ & $+/ 4$ & $-1-$ & $+1-$ & $\mathrm{T}$ & $\mathrm{E}$ \\
\hline & 84 & + & - & + & - & + & + & $\mathrm{D}$ & $E$ \\
\hline \multirow{7}{*}{$\begin{array}{l}V \\
E \\
R \\
\tilde{A} \\
O\end{array}$} & $35 !$ & + & + & + & - & - & + & $\mathrm{D}$ & $\mathrm{W}$ \\
\hline & 352 & $-1-$ & $-1+$ & $-1+$ & $+1-$ & $+1-$ & $-1-$ & $\mathrm{E}$ & $\mathrm{W} / \mathrm{E}$ \\
\hline & 353 & $+/+$ & $-1-$ & $-1-$ & $+1-$ & $+1 /$ & $+1-$ & $\mathrm{T}$ & $E$ \\
\hline & 354 & $-1+$ & $+1+$ & $+/+$ & $+1-$ & $+1+$ & $+/+$ & $\mathrm{D}$ & $\mathrm{W} / \mathrm{E}$ \\
\hline & 355 & $-1-$ & $-i-$ & $-1-$ & $+1+$ & $-1+$ & $-1-$ & $E$ & W/E \\
\hline & 356 & $+1-$ & $+1+$ & $+1-$ & $-1-$ & $-1+$ & $+1-$ & $\mathrm{T}$ & $\mathrm{E}$ \\
\hline & 357 & + & - & + & + & - & + & $D$ & $E$ \\
\hline
\end{tabular}

A parte central da Praia de Santos, onde foi levantado o perfil $82 / 355$, é a mais aberta para o mar e para as ondas mais enérgicas de SSW-S-SSE, sendo portanto o trecho de maior energia. Assim, é coerente que ali também esteja um centro de divergência de células de transportes costeiros.

No entanto, a dinâmica de circulação na Praia de Santos não é assim tão simples, pois os seis canais de saneamento e o espigão do emissário agem como defletores das 
ondas que incidem sobre a praia, gerando pequenas células entre eles, com sotamares nas suas faces. Isso é claramente observado no canal 3 que, além de localizado no centro da praia, é subperpendicular a ela e não perpendicular como os demais.

Os sinais negativos obtidos para os graus de seleção nas amostras $84 / 357$ provavelmente ocorreram devido à contribuição de sedimentos provenientes do Canal do Porto neste local.

Para as ortogonais de ondas medidas no campo (tabela 9), verificaram-se tendências semelhantes de transporte. Na Praia de São Vicente o transporte para W é devido a ondas de S35E (valor médio), com ângulos de incidência altos de até $35^{\circ}$. Em Itararé as ondas de S35E (média) geram correntes para ENE no extremo oeste, também com aitos ângulos $\left(44^{\circ}\right)$. Na porção central da praia os ângulos de incidência são muito baixos $\left(0-6^{\circ}\right)$, sugerindo a existência de correntes bidirecionais, para ENE e WSW, com ondas de rumo médio S17E. No extremo leste desta praia (ponto 81/354), dois trens de ondas atuam devido à difração na llha Urubuqueçaba e no espigão do emissário, gerando correntes para $\mathrm{E}$ (rumo médio de $\mathrm{S} 35 \mathrm{~W}$ ) e $\mathrm{W}$ (rumo médio de $\mathrm{S} 38 \mathrm{E}$ ) e criando uma zona de deposição, com o desenvolvimento de um tômbolo. Na Praia de Santos as ondas incidem com baixos ângulos no inverno, sugerindo transporte para WNW nos pontos 83 e 84 e para ESE no ponto 82. No verão, as tendências se inverteram, com ângulos excepcionalmente altos nos pontos 355 (WNW) e 357 (ESE) e muito baixo no ponto 356 (WNW/ESE).

\section{- Guaiúba}

Nesta praia foram feitas apenas duas amostragens representativas dos locais de maior (extremo noroeste) e menor (extremo sudeste) energia, variações estas bastante evidentes.

No extremo NW a largura é bem menor e a inclinação bem maior que no canto SE.

Da mesma forma verifica-se diminuição do tamanho dos grãos de NW para SE. No entanto, variações texturais ocorreram entre as duas etapas de amostragem, com diminuição do tamanho e do grau de seleção dos grãos (figura 30). No inverno predominavam areias finas $(83,3 \%)$ seguidas das areias médias $(16,7 \%)$, com graus de seleção variando entre bem $(50 \%)$, muito bem $(33,3 \%)$ e moderadamente selecionados $(16,7 \%)$. No verão, as areias finas passaram a $66,7 \%$ e as muito finas a $33,3 \%$, com o 
graus de seleção variando entre bem $(33,3 \%)$, moderadamente $(33,3 \%)$, muito bem $(16,7 \%)$ e pobremente selecionados $(16,7 \%)$.

Quando as amostras dos perfis 85 e 301 foram coletadas, notou-se grande homogeneidade granulométrica entre as lâminas de areia, sendo estas areias mais grossas que no outro extremo da praia. No entanto, nas coletas das amostras 86 e 302, foram observadas intercalações milimétricas a centimétricas entre areias mais finas com mais grossas. Estas intercalações, mais evidentes no verão, provocaram deslocamento na moda das areias, e portanto, uma inversão falsa na tendência de diminuição do tamanho dos grãos e do grau de seleção na praia. Este problema, que poderia gerar interpretações falsas na identificação do sentido da deriva litorânea, foi contornado com a aplicação da "matriz de comparação" (quadro 24). Ela confirmou a tendência observada no campo, de transporte de NW para SE, ou seja, uma célula com barlamar no extremo NW e sotamar no extremo SE. Os problemas constatados na amostragem, comentados anteriormente, parecem ser também responsáveis também pelo sinal negativo obtido para o grau de seleção da amostra 302 (zona de sotamar).

Os resultados obtidos refletem homogeneidade de atuação de células de deriva litorânea na praia, em relação a duas situações meteorológicas diferentes, com atuação de uma forte frente fria no inverno e condiçōes de tempo era bom no verão (calmaria instalada havia vários dias).

As ondas medidas no campo (tabela 9), propagando-se de S23-30W no inverno, indicam transportes para SE e para NW. Durante o verão não foram realizadas medidas de ondas devido a problemas com a bússola, mas como os ângulos de incidência eram altos, podia-se observar que provinham de SW e geravam derivas litorâneas para SE.

Quadro 24: Matriz de comparação elaborada para a Praia do Guaiúba

\begin{tabular}{|c|c|c|c|c|c|c|c|c|c|}
\hline & \multicolumn{3}{|c|}{ PARÁM. TEXTURAIS } & \multicolumn{2}{|c|}{ MORFOLOGIA } & \multirow[b]{2}{*}{$\begin{array}{c}\text { Resuitado } \\
\text { Final }\end{array}$} & \multirow[b]{2}{*}{$\begin{array}{c}\text { PROCESSO } \\
\text { E=erosão } \\
D=\text { =deposição } \\
T=\text { transporte }\end{array}$} & \multirow[b]{2}{*}{$\begin{array}{c}\text { SENTIDO } \\
\text { DA } \\
\text { DERIVA }\end{array}$} \\
\hline $\begin{array}{c}\text { Etapa } \\
\text { de } \\
\text { Amost }\end{array}$ & $\begin{array}{l}\text { Perfil } \\
\text { Praial }\end{array}$ & $\begin{array}{c}\text { Diâmetro } \\
\text { Médio }\end{array}$ & $\begin{array}{c}\text { Grau } \\
\text { de } \\
\text { Seleção }\end{array}$ & $\begin{array}{c}\text { Curto- } \\
\text { se }\end{array}$ & $\begin{array}{l}\text { Incli- } \\
\text { nação }\end{array}$ & $\begin{array}{l}\text { Largu- } \\
\text { ra }\end{array}$ & & & \\
\hline \multirow[t]{2}{*}{ INV. } & 85 & - & - & + & - & - & - & $E$ & $\mathrm{SE}$ \\
\hline & 86 & + & $\div$ & - & + & + & + & $\mathrm{D}$ & SE \\
\hline \multirow[t]{2}{*}{ VER. } & 301 & + & - & - & - & - & - & $E$ & $\overline{S E}$ \\
\hline & 302 & - & - & + & + & + & + & $\mathrm{D}$ & $\overline{S E}$ \\
\hline
\end{tabular}




\section{- Tombo}

Nesta praia foram também coletadas apenas duas amostras. Verificou-se que a energia era pouco maior no extremo NE, onde foi encontrada maior inclinação na antepraia, com ângulos de até $11^{\circ}$, e também da face litorânea $\left(5^{\circ}\right)$, sendo as areias mais grossas que no restante da praia.

No inverno, a largura da praia aumentou e a inclinação diminuiu de NE para SW, enquanto que o tamanho dos grãos e o grau de seleção diminuiram no mesmo sentido (figura 31). No verão, a largura aumentou e a inclinação diminuiu, enquanto que o tamanho dos grãos diminuiu e a seleção aumentou de NE para SW. Verificou-se ainda, do inverno para o verão, o afinamento generalizado das areias da praia e considerável melhora no grau de seleção pois, no inverno as areias eram médias (100\%) e moderadamente selecionadas $(100 \%)$, mas no verão predominaram areias finas $(66,7 \%)$, seguidas das areias médias $(33,3 \%)$, com termos muito bem $(50 \%)$, moderadamente $(33,3 \%)$ e bem selecionadas $(16,7 \%)$.

A "matriz de comparação" (quadro 25) permitiu reconhecer mais claramente as tendências de transporte, que se mantiveram semelhantes em ambas as etapas de amostragem, com uma célula definida por barlamar no extremo NE e sotamar no outro extremo (SW).

As ortogonais de ondas medidas no campo (tabela 9) mostraram que, durante a frente fria, o sentido da deriva seria invertido, gerando correntes para NE, o que seria esperado, uma vez que as ondas geradas no oceano se propagam de SSW a SSE durante esses eventos. No verão, correntes NE e SW poderiam estar convergindo no centro da praia.

Quadro 25: Matriz de comparação elaborada para a Praia do Tombo

\begin{tabular}{|c|c|c|c|c|c|c|c|c|c|}
\hline & \multicolumn{3}{|c|}{ PARÁM. TEXTURAIS } & \multicolumn{2}{|c|}{ MORFOLOGIA } & \multirow[b]{2}{*}{$\begin{array}{c}\text { Resultado } \\
\text { Final }\end{array}$} & \multirow[b]{2}{*}{$\begin{array}{c}\text { PROCESSO } \\
\text { E=erosão } \\
\mathrm{D}=\text { deposição } \\
\mathrm{T}=\text { transporte }\end{array}$} & \multirow[b]{2}{*}{$\begin{array}{c}\text { SENTIDO } \\
\text { DA } \\
\text { DERIVA }\end{array}$} \\
\hline $\begin{array}{c}\text { Etapa } \\
\text { de } \\
\text { Amost }\end{array}$ & $\begin{array}{l}\text { Perfil } \\
\text { Praial }\end{array}$ & $\begin{array}{c}\text { Diâmetro } \\
\text { Médio }\end{array}$ & $\begin{array}{c}\text { Grau } \\
\text { de } \\
\text { Seleção }\end{array}$ & $\begin{array}{l}\text { Curto- } \\
\text { se }\end{array}$ & $\begin{array}{l}\text { Incli- } \\
\text { nação }\end{array}$ & $\begin{array}{l}\text { Largu- } \\
\text { ra }\end{array}$ & & & \\
\hline \multirow[t]{2}{*}{ INV. } & 87 & + & - & - & + & + & + & $\mathrm{D}$ & SW \\
\hline & 88 & - & + & + & - & - & - & $\mathrm{E}$ & SW \\
\hline \multirow[t]{2}{*}{ VER. } & 303 & + & - & - & + & $\div$ & + & $\mathrm{D}$ & SW \\
\hline & 304 & - & - & + & - & - & - & $\mathrm{E}$ & SW \\
\hline
\end{tabular}


As cúspides, presentes nesta praia na maior parte do ano (foto 10), sugerem que a dinâmica de circulação possa ser mais complexa, com interferência de ondas de ressonância. Esta poderia eventualmente ser a explicação para o sinal negativo obtido para - grau de seleção da amostra 87 (zona de sotamar), sugerindo que o número de perfis levantados na praia possa ter sido insuficiente. Por outro lado, os valores deste parâmetro nas amostras 87 e 88 são muito próximos, havendo também a possibilidade da existência de erros na análise granulométrica ou nos cálculos estatísticos.

\section{- Astúrias e Pitangueiras}

Estas duas praias foram analisadas conjuntamente, pois representam segmentos de uma única praia, sendo isoladas apenas durante as preamares de sizígia. $\mathrm{Na}$ Praia das Pitangueiras a energia das ondas é claramente maior que nas Astúrias. Nesta última, a maior energia é encontrada no trecho centro-norte, e a menor no extremo sul, onde a praia é mais abrigada devida à presença da Ponta das Galhetas. Essa distribuição de energia é esperada em função da orientação N-S da praia e da sua forma de "cabo de guardachuva".

Em geral, a largura praial aumenta progressivamente do extremo sul da Praia das Astúrias rumo ao setor centro-norte da Praia das Pitangueiras, para depois voltar a diminuir até o extremo norte desta última. A inclinação das praias variou bastante entre o inverno e o verão. As maiores inclinações da antepraia $\left(2,5^{\circ}\right)$ do inverno foram medidas nos pontos 89 (sul de Astúrias) e 92 (centro-norte de Pitangueiras), mas no verão estavam nos pontos $306\left(3,5^{\circ}\right)$, ao norte da Praia das Astúrias e 308 e $309\left(3^{\circ}\right)$, ao centro-norte e extremo norte de Pitangueiras. Os perfis mais inclinados encontram-se no tômbolo formado na zona de sombra da llha da Pombeva. Em conseqüência da existência desta feição e das correntes associadas a ela, a praia sofre um forte embaiamento, principalmente a oeste do tômbolo.

Nessas praias foram verificadas variações texturais entre o inverno e o verão (figura 32), havendo aumento do tamanho do grãos e ligeira melhora no grau de seleção do inverno para o verão. No inverno $86,7 \%$ das areias eram muito finas e $13,3 \%$ finas, com $80 \%$ de termos muito bem, $13,3 \%$ de moderadamente e $6,7 \%$ bem selecionados. No verão, estavam presentes somente areias finas $(100 \%)$ e predominavam os termos muito bem $(86,6 \%)$, seguidos dos bem e moderadamente selecionados, cada qual com $6,7 \%$. Em 
geral, as areias da Praia das Astúrias são mais finas que na Praia das Pitangueiras, porém os graus de seleção são variáveis.

A "matriz de comparação" (quadro 26) mostra que na Praia das Astúrias o transporte predominante é para SSW a partir do extremo norte da mesma, situação que está de acordo com o esperado para praias com este tipo de geometria ("cabo de guardachuva"). Na Praia das Pitangueiras uma célula completa foi identificada no inverno, com barlamar ao norte da praia (ponto 93) e sotamar no extremo SW (ponto 91). No verão, um centro de divergência de duas pequenas células foi encontrado na porção central da praia (ponto 308), com sotamar nas duas extremidades. O transporte entre as duas praias também parece ocorrer, principalmente de Astúrias para Pitangueiras (ponto 90/306 é zona de barlamar em relação ao ponto $91 / 307$ ).

As ortogonais das ondas medidas no campo (tabela 9) indicaram tendências semelhantes aos resultados descritos acima.

A configuração da isóbata de $3 \mathrm{~m}$, observada na carta topográfica em escala 1:50.000 do 1.G.G. de 1972, ilustra muito bem essas células de transporte, mostrando a efetividade das mesmas.

Quadro 26: Matriz de comparação elaborada para as Praias das Astúrias e Pitangueiras

\begin{tabular}{|c|c|c|c|c|c|c|c|c|c|}
\hline & \multicolumn{3}{|c|}{ PARÁM. TEXTURAIS } & \multicolumn{2}{|c|}{ MORFOLOGIA } & \multirow[b]{2}{*}{$\begin{array}{c}\text { Resultado } \\
\text { Final }\end{array}$} & \multirow[b]{2}{*}{$\begin{array}{c}\text { PROCESSO } \\
\mathrm{E}=\text { =erosão } \\
\mathrm{D}=\text { deposição } \\
\mathrm{T}=\text { transporte }\end{array}$} & \multirow[b]{2}{*}{$\begin{array}{c}\text { SENTIDO } \\
\text { DA } \\
\text { DERIVA }\end{array}$} \\
\hline $\begin{array}{c}\text { Etapa } \\
\text { de } \\
\text { Amost }\end{array}$ & $\begin{array}{l}\text { Perfil } \\
\text { Praial }\end{array}$ & $\begin{array}{c}\text { Diâmetro } \\
\text { Médio }\end{array}$ & $\begin{array}{c}\text { Grau } \\
\text { de } \\
\text { Seleção }\end{array}$ & $\begin{array}{c}\text { Curto- } \\
\text { se }\end{array}$ & $\begin{array}{l}\text { Incli- } \\
\text { nação }\end{array}$ & $\begin{array}{c}\text { Largu- } \\
\text { ra }\end{array}$ & & & \\
\hline \multirow{5}{*}{ INV. } & 89 & + & + & + & - & - & + & $\mathrm{D}$ & SW \\
\hline & 90 & $-1-$ & $-1-$ & $-1+$ & $+/+$ & $+1-$ & $-1-$ & $\mathrm{E}$ & SW/NE \\
\hline & 91 & $+1-$ & $+/+$ & $-1+$ & $-1+$ & $+1+$ & $+1+$ & $\mathrm{D}$ & ENE/WSW \\
\hline & 92 & $+1+$ & $-1+$ & $-1-$ & $-1 /-$ & $-1+$ & $-1+$ & $\mathrm{T}$ & SW \\
\hline & 93 & - & - & + & + & - & - & $\mathrm{E}$ & $\mathrm{SW}$ \\
\hline \multirow{5}{*}{ VER. } & 305 & + & + & + & + & - & + & $\bar{D}$ & SW \\
\hline & 306 & $-1-$ & $-i m$ & $-1-$ & $-1-$ & $+1-$ & $-1-$ & $E$ & $\mathrm{SW} / \mathrm{NE}$ \\
\hline & 307 & $+/ t$ & $+1-$ & $+/ t$ & $+/ 4$ & $+/-$ & $+/+$ & $\mathrm{D}$ & $\mathrm{SW} / \mathrm{NE}$ \\
\hline & 308 & $-1-$ & $+1-$ & $-1-$ & $-1+$ & $+/+$ & $-1-$ & $E$ & $\mathrm{SW} / \mathrm{NE}$ \\
\hline & 309 & + & + & + & - & - & + & $\mathrm{D}$ & $\mathrm{NE}$ \\
\hline
\end{tabular}




\section{- Enseada}

As larguras medidas no inverno foram menores que no verão, em decorrência da frente fria que atuava por vários dias na região, somada à ação da maré de sizígia. No verão o tempo estava bom por vários dias e a maré era de quadratura. As menores larguras foram encontradas nos dois extremos da praia (principalmente no SE), a partir dos quais a praia se alarga até o ponto 95/311. As menores inclinações estão nas extremidades e aumentam para o centro. Os perfis mais declivosos correspondem ao ponto $96 / 312$.

Nesta praia também foram constatadas variações texturais entre o inverno para o verão (figura 33). No inverno havia somente areias muito finas e muito bem selecionadas. No verão, entretanto, as areias tornaram-se finas e muito bem selecionadas, com ligeiro aumento relativo no grau de seleção. Em geral, foi verificada tendência ao ligeiro afinamento dos grãos de $W$ para $E$. O grau de seleção variou entre os termos muito bem selecionados, mas mostrou-se pouco melhor no setor centro-sul da praia.

A partir da "matriz de comparação" (quadro 27) foram identificadas duas células de deriva litorânea, tanto no inverno como no verão, com barlamares localizados nos pontos $94 / 310$ e $96 / 312$, e sotamares nos pontos $95 / 311$ e $97 / 313$. Os locais onde ocorrem as zonas de barlamar correspondem a pontos de maior concentração de energia na praia para os trens de ondas de SW e SE. A configuração das isóbatas de 3 e $6 \mathrm{~m}$, observada na carta topográfica de 1971 em escala 1:50.000 do I.G.G., essas células de transporte aparecem bem ilustradas, mostrando a efetividade das mesmas.

As ortogonais das ondas medidas no campo (tabela 9) indicaram tendências semelhantes para o inverno e verão, com transporte para $E$ (ENE e ESE) associado a ondas de S20W a S25E, e transporte para W (WNW e WSW) ligado a ondas de S69W (média). Em ambas as etapas de amostragem predominaram os transportes para $E$, sendo o para W restrito ao extremo SE da praia ou ao extremo oposto (foto 9).

Esta predominância de transporte para $E$ foi também verificada por HIDROCONSULT (1974/1975) por medições de correntes no largo, em situações meteorológicas diferentes. 
Quadro 27: Matriz de comparação elaborada para a Praia da Enseada

\begin{tabular}{|c|c|c|c|c|c|c|c|c|c|}
\hline \multirow[b]{2}{*}{$\begin{array}{c}\text { Etapa } \\
\text { de } \\
\text { Amost }\end{array}$} & \multirow[b]{2}{*}{$\begin{array}{l}\text { Perfil } \\
\text { Praial }\end{array}$} & \multicolumn{3}{|c|}{ PARÂM. TEXTURAIS } & \multicolumn{2}{|c|}{ MORFOLOGIA } & \multirow[b]{2}{*}{$\begin{array}{l}\text { Resultado } \\
\text { Final }\end{array}$} & \multirow[b]{2}{*}{$\begin{array}{c}\text { PROCESSO } \\
\mathrm{E}=\text { =rosão } \\
\mathrm{D}=\text { deposição } \\
\mathrm{T}=\text { transporte } \\
\end{array}$} & \multirow[b]{2}{*}{$\begin{array}{c}\text { SENTIDO } \\
\text { DA } \\
\text { DERIVA }\end{array}$} \\
\hline & & $\begin{array}{c}\text { Diâmetro } \\
\text { Médio }\end{array}$ & $\begin{array}{c}\text { Grau } \\
\text { de } \\
\text { Seleção }\end{array}$ & $\begin{array}{c}\text { Curto- } \\
\text { se }\end{array}$ & $\begin{array}{l}\text { Incli- } \\
\text { nação }\end{array}$ & $\begin{array}{l}\text { Largu- } \\
\text { ra }\end{array}$ & & & \\
\hline \multirow{4}{*}{ INV. } & 94 & - & - & - & + & - & - & $\mathrm{E}$ & ENE \\
\hline & $\overline{95}$ & $+1-$ & $+/ t$ & $+/ t$ & $-1+$ & $t / t$ & $+1+$ & $\bar{D}$ & ENE/WSW \\
\hline & 96 & $+1-$ & $-1+$ & $-1-$ & $-1-$ & $-1+$ & $-1-$ & $\mathrm{E}$ & WSW/ESE \\
\hline & 97 & + & - & + & + & - & + & $\mathrm{D}$ & ESE \\
\hline \multirow{4}{*}{ VER. } & 310 & - & - & - & + & - & - & $\mathrm{E}$ & ENE \\
\hline & 311 & $+1+$ & $+/ t$ & $+/+$ & $-1-$ & $+1+$ & $+/+$ & $\mathrm{D}$ & ENE/WSW \\
\hline & 312 & $-1-$ & $-1-$ & $-1-$ & $+1-$ & $-1+$ & $-1-$ & $\mathrm{E}$ & WSW/ESE \\
\hline & 313 & + & + & + & + & - & + & $\mathrm{D}$ & $\mathrm{ESE}$ \\
\hline
\end{tabular}

\section{- Pernambuco e Mar Casado}

Estas praias são unidas por um tômbolo formado atrás da llha do Mar Casado. Há forte diferenças em termos de energia entre elas, sendo maior na Praia de Pernambuco.

A largura da praia é maior e a inclinação menor, o tamanho dos grãos é menor e o grau de seleção maior (figura 34) na Praia do Mar Casado. Há aumento progressivo na granulometria e na inclinação, acompanhado de diminuição do grau de seleção e de largura praial, da Praia do Mar Casado para a porção NE da Praia de Pernambuco. Nesse trecho (perfil 100/316) as areias são finas e moderadamente selecionadas, passando a muito finas e muito bem selecionadas na Praia do Mar Casado. Cúspides praiais mal desenvolvidas ocorrem em Pernambuco.

Com a "matriz de comparação" (quadro 28) foi reconhecida a presença de uma célula completa, com barlamar no trecho norte da Praia de Pernambuco (ponto 100/316). Obviamente, como existe um tômbolo entre as duas praias, a célula se completa na extremidade SSW de Pernambuco. Outra pequena célula ocorre ao longo da Praia do Mar Casado, com sotamar no tômbolo. Assim, os transportes predominantes são SSW na Praia de Pernambuco e NE na Praia do Mar Casado.

As ortogonais das ondas medidas no campo (tabela 9) sugerem a existência de pequenas células com orientações variadas. Ondas de N70E a S85E causam derivas para norte, ao sul da Praia de Pernambuco e ondas de S50E e S15E geram correntes, respectivamente, para SSW e NNE ao norte da Praia de Pernambuco. 
Quadro 28: Matriz de comparação elaborada para as praias de Pernambuco e Mar Casado

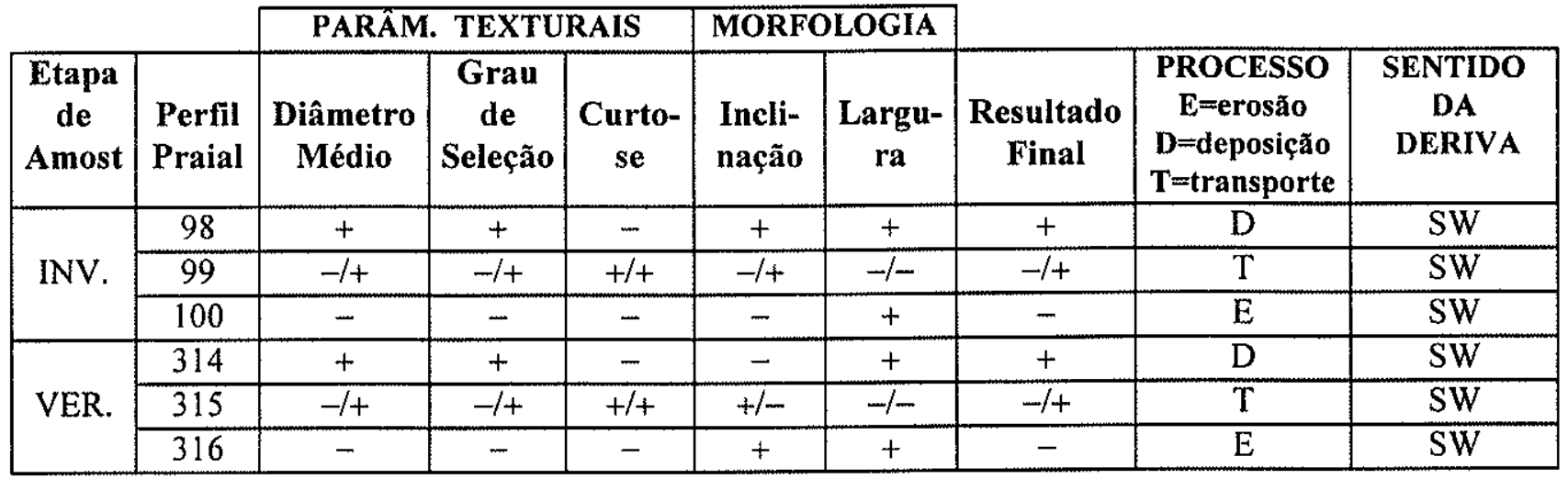

\section{- Perequê}

Esta praia possui um forma característica de "cabo de guarda-chuva" e, como tal, apresenta maior energia no setor centro-norte.

Na Praia do Perequê ocorre diminuição de largura e aumento da inclinação na sua parte central da mesma, estando as maiores larguras e menores inclinações no extremo sul da praia.

No inverno as areias mostraram-se muito finas (100\%) e muito bem selecionadas $(100 \%)$, com diminuição do tamanho dos grãos de sul para norte (figura 35). No verão, embora predominassem areias muito finas $(77,8 \%)$, apareceram também areias finas $(22,2 \%)$, ambas muito bem selecionadas. Verificou-se afinamento dos grãos e melhora do grau de seleção no centro da praia.

Com a "matriz de comparação" (quadro 29) foram diagnosticadas duas células divergentes a partir do setor central da praia, com sotamares nas extremidades, como seria esperado para este tipo de praia.

Os sinais negativos encontrados para os graus de seleção nas zonas de sotamar nas extremidades da praia, provavelmente são atribuíveis às contribuições de sedimentos de rios que desembocam nessas áreas. 
Quadro 29: Matriz de comparação elaborada para a Praia do Perequê

\begin{tabular}{|c|c|c|c|c|c|c|c|c|c|}
\hline & \multicolumn{3}{|c|}{ PARÁM. TEXTURAIS } & \multicolumn{2}{|c|}{ MORFOLOGIA } & \multirow[b]{2}{*}{$\begin{array}{l}\text { Resultado } \\
\text { Final }\end{array}$} & \multirow[b]{2}{*}{$\begin{array}{c}\text { PROCESSO } \\
\text { E=erosão } \\
\text { D=deposição } \\
T=\text { transporte }\end{array}$} & \multirow[b]{2}{*}{$\begin{array}{c}\text { SENTIDO } \\
\text { DA } \\
\text { DERIVA }\end{array}$} \\
\hline $\begin{array}{c}\text { Etapa } \\
\text { de } \\
\text { Amost }\end{array}$ & $\begin{array}{l}\text { Perfil } \\
\text { Praial }\end{array}$ & $\begin{array}{l}\text { Diâmetro } \\
\text { Médio }\end{array}$ & \begin{tabular}{|c|} 
Grau \\
de \\
Seleção
\end{tabular} & $\begin{array}{l}\text { Curto- } \\
\text { se }\end{array}$ & $\begin{array}{l}\text { Incli- } \\
\text { nação }\end{array}$ & $\begin{array}{l}\text { Largu- } \\
\text { ra }\end{array}$ & & & \\
\hline \multirow{3}{*}{ INV. } & 101 & - & - & + & + & + & + & $\mathrm{D}$ & SSE \\
\hline & 102 & $+1+$ & $+1 t$ & $-1-$ & $-1-$ & $-1-$ & $-1-$ & $\mathrm{E}$ & SSE/NNW \\
\hline & 103 & - & - & + & + & + & + & $\bar{D}$ & NNW \\
\hline \multirow{3}{*}{ VER. } & 318 & - & - & + & + & + & + & $\mathrm{D}$ & SSE \\
\hline & 319 & $+/+$ & $+/ t$ & $-/-$ & $-1-$ & $-1-$ & $-1-$ & $\bar{E}$ & SSE/NNW \\
\hline & 320 & - & - & + & + & + & + & $\overline{\mathrm{D}}$ & NNW \\
\hline
\end{tabular}

As ortogonais das ondas medidas no campo (tabela 9) sugerem células de deriva litorânea com comportamentos semelhantes ao descritos acima. As ondas de rumo médio N85E estariam gerando transporte para SSW, enquanto as ondas de rumo médio S63E seriam responsáveis por transporte para NNE.

\section{- São Pedro e lporanga}

A Praia de Iporanga foi estudada junto com a de São Pedro porque são muito próximas e apenas uma amostra foi coletada nela. A energia das ondas é bem maior na Praia de São Pedro, porque ela está orientada segundo a direção SSW-ENE, isto é, mais aberta para as ondas do quadrante SE, enquanto que a Praia de Iporanga tem orientação SSE-NNW, estando mais abrigada. A maior energia da Praia de São Pedro está na porção centro-norte, onde a largura praial é menor e a inclinação maior (pontos 105/323 e 106/324).

A granulometria das areias mostroumse bastante variada na Praia de São Pedro (figura 36 ), sendo mais grossa no inverno, quando predominaram, areias grossas $(55,6 \%)$ e bem selecionadas $(77,8 \%)$, seguidas das areias médias $(44,4 \%)$ e moderadamente selecionadas $(22,2 \%)$. No verão apareceram areias finas $(44,4 \%)$, com conseqüente decréscimo na freqüência das areias grossas $(11,1 \%)$, conservando-se as areias médias $(44,4 \%)$. No verão apareceram também os termos muito bem selecionados $(22,2 \%)$, mas ainda predominaram os bem selecionados $(66,7 \%)$, e diminuindo os moderadamente selecionados $(11,1 \%)$. Em ambas etapas de amostragem o tamanho dos grãos aumentou 
rumo ao centro da praia, mas o grau de seleção foi maior ao sul, no inverno, e maior ao norte, no verão.

$\mathrm{Na}$ Praia de Iporanga as areias encontravam-se muito finas e muito bem selecionadas no inverno e finas e muito bem selecionadas no verão. Portanto, tornaram-se mais grossas no verão, inversamente ao que ocorreu na Praia de São Pedro. Cuidados devem ser tomados quanto à interpretação deste fato, pois em ambas as etapas apenas um perfil foi analisado nesta praia. As variações constatadas na Praia de São Pedro podem ser explicadas pela maior atuação de frentes frias no inverno, possibilitando o transporte de sedimentos mais grossos, devido às ondas mais enérgicas. No verão, diminuindo a competência das ondas, as partículas menores são facilmente incluídas na moda das areias praiais.

O quadro 30 mostra que, pela "matriz de comparação" foram reconhecidas no inverno, duas células divergentes na porção central da Praia de São Pedro. No verão, a zona de barlamar estava no extremo norte, com sotamar no setor sul da praia. Como era esperado, a Praia de Iporanga apresentou um caráter mais deposicional que a Praia de São Pedro.

Quadro 30: Matriz de comparação elaborada para as praias de São Pedro e Iporanga

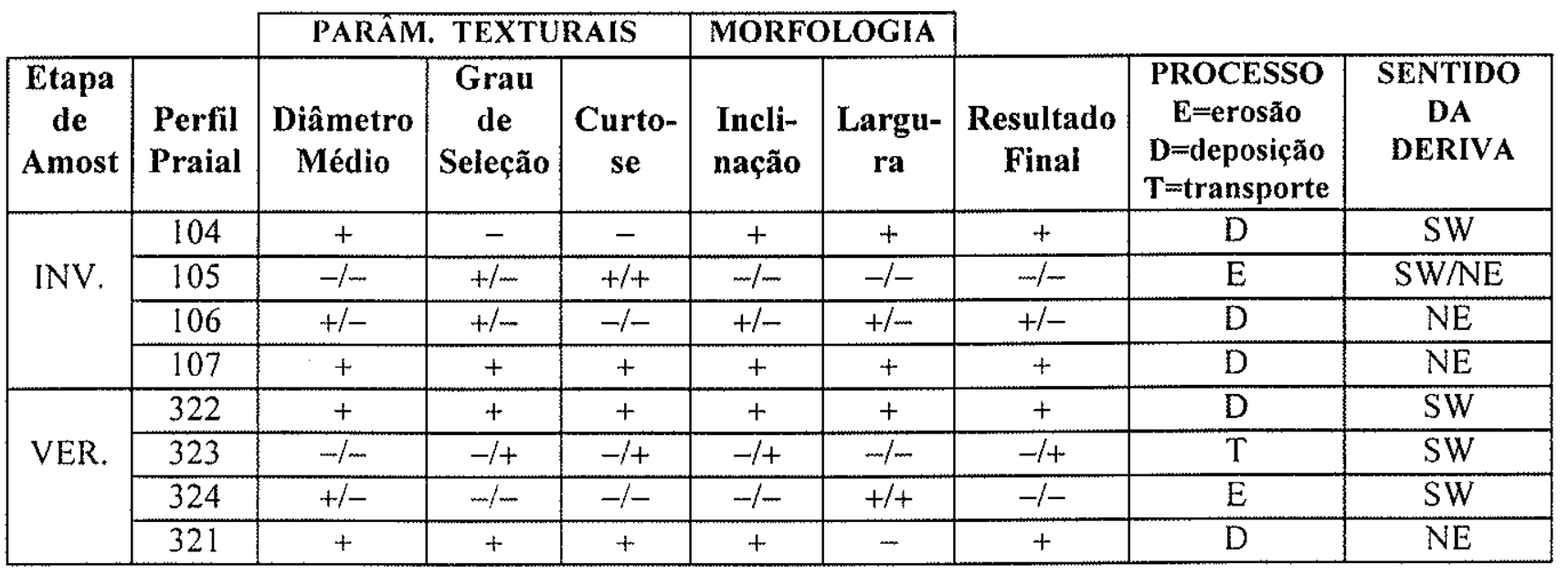

O sinal negativo obtido para o grau de seleção no ponto 104 provavelmente deve-se a erros na análise granulómétrica ou aos cálculos estatísticos. 
As ortogonais das ondas medidas na Praia de São Pedro (tabela 9) sugerem transportes para SW associados a ondas de S20-87E e ondas de S25E gerando células para NE.

\section{4. 3. MÉTOdO DE MCLAREN}

Os quadros 31 e 32 (Volume II) mostram uma supremacia de transporte para norte (NE, E, N, NW), rumo a Bertioga, em relação ao transporte no sentido oposto (W, SW, $S$, SE). Padrão de transporte predominante para sul ocorreu ao longo de faixas bem definidas, isto é, ao sul, entre as praias da Baía de Santos e Astúrias e ao norte, entre as praias de Pernambuco e São Pedro. Algumas tendências ficaram bem marcadas, como estão descritas nos itens seguintes.

(a) Os casos positivos corresponderam a $24,4 \%$ no inverno e $26,9 \%$ no verão, em relação ao total de combinações possíveis.

(b) No inverno, 66,1\% dos casos positivos corresponderam ao transporte para norte (Zestatístico $=13,187)$, e 33,9\% ao transporte para sul $(Z$ - estatístico $=2,650)$. No verão, também predominou o transporte para norte, com freqüência de $56,4 \%$ (Z- estatístico $=$ $11,272)$, e $43,6 \%$ para sul $(Z$ - estatístico $=6,916)$. Portanto, ambos os sentidos de transporte são possiveis, com freqüências quase eqüivalentes.

(c) Os casos B predominaram em ambas as etapas, com freqüência de $71,4 \%$ no inverno e $54,7 \%$ no verão; e apenas os casos com rumo norte atingiram níveis de significância: Z- $\operatorname{Binv}(N)=9,113$ e $Z$ - $B$ ver $(N)=3,140$.

(d) A Praia de São Vicente (ponto 78/351) não é área-fonte para outras praias, mas exibe fontes relacionadas a várias, principalmente nas praias de Itararé e Santos.

(e) As praias de Itararé e Santos são principalmente fontes delas mesmas, mas ainda contam com as praias de Guaiúba e Tombo como suas fontes, ficando bem caracterizados os transportes para oeste ao longo da Praia de Santos rumo à Praia de Itararé e das praias ao sul da liha de Santo Amaro rumo à Baia de Santos.

(f) O transporte da Baia de Santos rumo a NE fica evidente quando se observa que as amostras 79/352,81/354,82/355 e 83/356 representam áreas-fonte para a maioria das praias ao norte. 
(g) A continüidade do transporte para NE é observada também nas praias de Guaiúba e Tombo, que são áreas-fonte de muitas praias ao norte.

(h) Em ambas as etapas de amostragem a Praia da Enseada representa não ser área-fonte das outras praias. No entanto, ela tem muitas fontes locais, sugerindo grande retenção de sedimentos nessa praia.

(i) Deste trecho, para o norte, as praias contribuem mais com transporte para SW, sendo as praias de Pernambuco e São Pedro áreas-fonte de várias praias ao sul, até a Praia das Astúrias.

(j) Este transporte para SW é mais freqüente no verão, pois no inverno a maior atuação das frentes fria faz com que as ondas de SSW a SSE deslocam as derivas litorâneas mais para NE. No verão, as ondas de SE e ESE agem mais frontalmente neste trecho de costa defletindo o transporte para SW.

(k) As amostras 84/357 e 100/316 representam áreas-fonte da maioria dos outros sedimentos, mas praticamente não têm fontes locais, sugerindo predomínio de processos erosivos.

VI. 4. 4. CONCLUSÕES

O quadro 33 mostra as distribuições percentuais de transporte obtidas pelos métodos utilizados. Os dados das fotos aéreas de 1962 não foram computados.

Em geral, houve boa correlação entre os três métodos utilizados. O quadro 33 mostra que os resultados são bastante próximos e que não há predominância absoluta de rumos de transporte.

Apenas o método de McLAREN permitiu estabelecer uma diferença clara da predominância de transporte para norte em função da atuação das frentes frias no inverno. O método de TAGGART \& SCHWARTZ-modificado, bem como os resultados de ondas medidas no campo e nas fotografias aéreas e os dados do método de MCLAREN para o verão, não permitiram reconhecer tendências predominantes de transportes regionais em função de variações meteorológicas. Isso era esperado porque a linha de costa do setor IV é bastante recortada e as praias têm orientações diferentes. 
Quadro 33. Comparação entre os resultados percentuais dos rumos de transporte obtidos a partir dos diferentes métodos utilizados.

\begin{tabular}{|c|c|c|c|c|}
\cline { 2 - 4 } \multicolumn{1}{c|}{} & \multicolumn{2}{|c|}{$\begin{array}{c}\text { INVERNO } \\
\text { TRANSPORTE }\end{array}$} & \multicolumn{2}{c|}{ TRANSPORTE } \\
\hline MÉTODO & $N W, N, N E, E$ & $W, S W, S, S E$ & $N W, N, N E, E$ & $W, S W, S, S E$ \\
\hline Taggart \& Schwartz-modif. & $45,9 \%$ & $54,1 \%$ & $48,6 \%$ & $51,4 \%$ \\
\hline McLaren & $66,1 \%$ & $33,9 \%$ & $56,4 \%$ & $43,6 \%$ \\
\hline Ondas - Campo & $57,6 \%$ & $42,4 \%$ & $57,6 \%$ & $42,4 \%$ \\
\hline Ondas - Fotos Aéreas & $50,0 \%$ & $50,0 \%$ & $40,0 \%$ & $60,0 \%$ \\
\hline
\end{tabular}

No inverno, $86,7 \%$ das amostragens foram feitas sob condições de frente fria e $13,3 \%$ sob tempo bom. No verão $100 \%$ corresponderam a condições de tempo bom. Entretanto, como foi ressaltado anteriormente, por nenhum dos métodos ficou demonstrada predominância muito acentuada de um ou outro rumo de transporte. Isso parece estar de acordo com os resultados das medições de correntes efetuadas ao longo da llha de Santo Amaro (HIDROCONSULT, 1974/1975) e no interior da Baía de Santos (SONDOTÉCNICA, 1977), sob diferentes condições meteorológicas.

Portanto, conclui-se que ambos os sentidos de transporte atuam mais ou menos igualmente neste setor, independentemente das condições meteorológicas, embora as células de deriva litorânea locais possam ser deslocadas.

Em geral, pode-se concluir que no interior da Baia de Santos predominam transportes para $W$, embora atuem pequenas células com sentidos opostos, formadas principalmente entre os canais de saneamento e o espigão do enrocamento, provocando acumulações nas faces dos mesmos. A atuação dessas células explica também porque a prefeitura municipal, através da PRODESAN S/A, promove a remoção semanal de centenas de metros cúbicos de areia que se acumula nas margens desses canais (foto $8 b$ ), em especial do canal 3. Além desta remoção, muita areia é também subtraída pelas atividades de limpeza da praia e da retirada dos "excessos" (chamados assim indevidamente) de areias acumuladas por ação eólica ou após as ressacas nas muretas próximas ao passeio público. De acordo com informações prestadas pela PRODESAN, 
entre os anos de 1990 e agosto de 1993, cerca de $41.875 \mathrm{~m}^{3}$ de areia foram extraídos da Praia de Santos, em especial das proximidades dos canais 2 e 3 (CEPA/USP, 1994).

O espigão do emissário de Santos-São Vicente (fotos $8 a$ e $8 b$ ) bloqueia parte da transferência de sedimentos entre as praias de Santos e Itararé, e deflete as ondas gerando pequenas células locais. Processos erosivos já são notados na face oeste do canal 1. Nas duas faces do espigão, por outro lado, aparentemente predominam processos deposicionais, embora haja forte assimetria praial, com retrogradação na face leste (voltada para o canal 1). A progradação da praia na face oeste do espigão ocorre devida à zona de sombra formada pela llha Urubuqueçaba ( tômbolo).

A Praia de Itararé é a única onde a urbanização foi iniciada recentemente, em meados de 1996 (foto 8c). Antes da urbanização, a distância entre a pós-praia e a avenida beira-mar era bastante grande, da ordem de centenas de metros, permitindo assim o franco desenvolvimento do jundu e livre retrabalhamento eólico das areias. Esta praia mostrava sinais de relativa estabilidade, dispondo de abundante estoque sedimentar. Embora seja a praia mais aberta para o oceano, não sofre com as ressacas como a Praia de São Vicente. Atualmente, estão em construção vários quiosques de alvenaria sobre a área livre onde se desenvolvia o jundu. Este fato é lamentável pois certamente virá a prejudicar ainda mais o balanço sedimentar nas praias do interior da Baía de Santos.

A Praia de São Vicente, por outro lado, encontra-se intensamente urbanizada e modificada por intervenções antrópicas, como espigões e anteparos (muretas, alinhamento de blocos rochosos) para conter a erosão costeira e a própria urbanização sobre a póspraia. Além disso, o fechamento da passagem do tômbolo da Ilha Porchat, isolou as baías de São Vicente e de Santos, limitando o transporte longitudinal de areias entre suas praias e provocando intensificação dos processos erosivos ao longo da orla de São Vicente. Essa foi também uma conclusão importante obtida por CTH-USP/DAEE (1976). Com a construção do longo espigão do emissário de Santos-São Vicente, a situação piorou ainda mais, porque as areias transportadas ao longo da praia de Santos agora são bloqueadas por ele e depois perdem-se para o largo. Mesmo assim, os resultados obtidos aqui sugerem que ainda há transportes entre as duas baías, o que pode ocorrer através de correntes de maré enchente. Segundo dados de SONDOTÉCNICA (1977), as correntes de maré têm baixas velocidades e rumam, no fundo, da parte central da Baía de Santos para a Baía de São Vicente. Portanto, somente as frações mais finas das areias que vão parar 
no largo de Santos, através das correntes de deriva litorânea e de retorno defletidas no espigão, seriam transportadas para a Praia de São Vicente pelas correntes de maré enchente que penetram nesta baía margeando a praia (CTH-USP/DAEE, 1976).

Ao longo da llha de Santo Amaro o sentido geral de transporte é dirigido predominantemente para o norte até a Praia da Enseada. Esta praia parece receber grande volume de sedimentos provenientes, principalmente de sul, os quais permanecem retidos ali por longo tempo. Isso pode explicar porque ela constitui a única desse setor onde se desenvolvem dunas embrionárias (porção central-norte da mesma) e, também, porque processos erosivos são raramente observados nela, sendo uma das poucas praias de São Paulo que parece estar em estado de relativo equilíbrio. Parte dos sedimentos que está alimentando a Praia da Enseada pode ser derivado do material que é dragado do Canal de acesso ao Porto de Santos, o qual é despejado nas proximidades da Ponta do Munduba, entre a Ilha da Moela e o continente.

São muito preocupantes a densa urbanização de toda a linha de costa do setor IV, bem como a série de modificações que ela vem sofrendo, seja pela construção de estruturas rígidas na orla, seja pela intensa extração de areia de praia, que também ocorre nas praias do Guarujá, em especial nas de Astúrias e Pitangueiras e parte oeste da Enseada. A recente urbanização da Praia do Itararé pode provocar uma desestabilização ainda maior nas praias das Baías de Santos e São Vicente, já muito castigadas pelas várias intervenções na orla, limitando um importante estoque local de sedimentos. Note-se bem que também os canais do interior do Estuário Santista são regularmente dragados.

PONÇANO et al al. (1994, in NAKAZAWA, et al.,1994) sugeriram a predominância de transportes costa adentro e costa afora para todo este Setor, com tendências de transportes para SW ao longo da Ilha de Santo Amaro e SE na saída da Baía de Santos (figura 3). Estas tendências são, em geral, bastante diferentes das obtidas neste estudo. Por outro lado, parece incongruente o fato desses autores atribuírem a predominância de transportes costa adentro e costa afora no trecho ao norte da Ilha de Santo Amaro, onde a costa é bastante recortada e as praias têm características morfodinâmicas predominantemente intermediárias e mistas.

Foi também interessante observar, neste setor, a ocorrência de mudanças nas distribuições granulométricas de todas as praias, entre o inverno e o verão, ora 
acentuadas, ora sutis. Nos setores morfodinâmicos ao sul isso não foi observado, com raras exceções (Rio Verde, Una e Peruíbe).

Quatro possibilidades de variação, entre o inverno e o verão, foram encontradas:

1. diminuição de tamanho dos grãos acompanhada de aumento no grau de seleção, como nas praias de Itararé, Santos, Tombo e São Pedro;

2. diminuição de tamanho dos grãos acompanhada de diminuição no grau de seleção, como na Praia do Guaiúba;

3. aumento de tamanho dos grãos acompanhada de aumento no grau de seleção, como nas praias de Astúrias, Pitangueiras e Enseada;

4. aumento de tamanho dos grãos acompanhada de diminuição no grau de seleção, como nas praias do Perequê e Iporanga.

Os casos 1 e 3 indicariam retrabalhamentos das areias da praia, promovendo melhora no grau de seleção, sob condições de alta energia (caso 1), com remoção total ou parcial das frações mais grossas e permanência das mais finas e baixa energia (caso 3), que seria suficiente apenas para remover as frações mais finas, deixando as mais grossas.

Os casos 2 e 4 sugerem o aporte de novos sedimentos à praia, promovendo a diminuição do grau de seleção, sob condições de alta energia (caso 4) e baixa energia (caso 2).

Nota-se ainda que, excetuando-se a Praia de São Pedro, as demais praias estão inseridas em casos, segundo conjuntos geograficamente melhor definidos. As Praias do Rio Verde, Una e Peruibe estariam inseridas no caso 1.

\section{5. SETOR MORFODINÂMICO V}

As praias estudadas neste Setor foram: Bertioga, São Lourenço, Itaguaré, Guaratuba, Boracéia, Juquehy, Baleia, Boiçucanga, Maresias, Santiago e Toque-Toque Pequeno, Guaecá e Barequeçaba. 


\section{4. 1. Análise de Produtos de Sensoriamento Remoto}

Foram utilizadas as fotografias aéreas de 1962, 1965/1966, 1987 e 1994 (quadro 3).

A figura 37 mostra que, ao longo de todo este setor, predomina o transporte geral rumo W/SW/NW, ou seja, rumo ao Canal da Bertioga. Este transporte ocorre nas praias e também pode ser visualizado pela deriva de plumas de material em suspensão que caminham ao largo ou ao redor dos costões rochosos, embora células menores de rumo oposto também ocorrem, localmente. Nas imagens de satélite de 1976 e da década de 90 ambos são observados.

Nas praias de Bertioga, Itaguaré, Guaratuba e Boracéia predomina uma grande célula de rumo W/SW. Nas praias de Guaratuba, Juquehy e Guaecá várias células puderam ser reconhecidas. Nas demais praias, em geral, ocorrem duas células principais.

É interessante notar que, em especial nas fotos aéreas de 1994, várias células pequenas foram identificadas na maioria das praias. Isso seria dificil de explicar pela escala (1: 25.000), que é igual à maioria dos outros vôos analisados e, além disso, o mês do ano e a fase de maré astronômica também coincidem com outros vôos. Por outro lado, várias dessas pequenas células foram também observadas nas fotos de 1987, cuja escala é de 1 : 10.000. Talvez a ocupação antrópica acelerada a partir da década de 80 , com urbanização de várias praias, esteja causando modificações nos ângulos de incidência de ondas junto à costa, provocando alterações nas células de deriva litorânea, e/ou no balanço sedimentar dessas praias. Em geral, os transportes principais mantiveram-se semelhantes aos identificados nos vôos anteriores.

As medições de ortogonais de ondas feitas nas fotos aéreas (tabela 10) mostram que cerca de $67,3 \%$ das medidas estão associadas a transportes de W/SW/SSW. Essas correntes são geradas por ondas de espectro amplo, que dependem da orientação da costa, variando de S17W a S62E. No trecho entre as praias de Bertioga e Boracéia o valor médio obtido para essas ondas foi de S25E, embora predominem rumos mais elevados, em torno de S37E. De Juquehy até Guaecá os valores médios são de S20E, para os trens incidentes do quadrante SE, e S10W para os do quadrante SW. O transporte para NE está associado a ondas de S29E (rumo médio), no trecho entre Bertioga e Juquehy, e de S37W (rumo médio) para as praias ao norte dele. 


\section{5. 2. MÉTODO DE TAGGART \& SCHWARTZ-MODIFICADO}

A figura 38 exibe os resultados obtidos para o setor $V$ a partir da aplicação deste método. Na tabela 11 são encontrados os dados relativos às medições de ortogonais das ondas no campo.

O comportamento morfológico das praias deste setor pode ser vistos nas figuras $39 a, 39 b, 40 a, 40 b$ e $40 c$.

\section{- Bertioga}

As larguras medidas no verão foram maiores que no inverno, ultrapassando $100 \mathrm{~m}$ em todos os perfis. Isto ocorreu devido à severa frente fria instalada nos dias que antecederam os trabalhos de campo no inverno. No verão, a frente fria acabara de se instalar, com fraca intensidade. No inverno verificou-se diminuição gradativa da largura praial, do extremo sul para o extremo norte, mas isso não ocorreu no verão. A maior largura medida no verão foi no centro da praia (perfil 334). As inclinações dos perfis foram também ligeiramente maiores no verão, atestando o maior poder erosivo da frente fria do inverno. Nesta última encontrou-se ligeira diminuição da inclinação da antepraia, de sul para norte, estando coerente com as variações de largura. No verão, porém, o perfil mais declivoso foi justamente o mais largo (perfil 334). Nenhuma feição tipo cúspide ou berma foi encontrada no local, que justifique esse antagonismo.

Em Bertioga as areias são muito finas e muito bem selecionadas (figura 41), e apenas tênues variações desses parâmetros ocorrem ao longo da praia, características que não se mantiveram nas duas etapas de amostragem. Em geral, percebe-se ligeiro aumento no tamanho dos grãos no centro da praia (perfil 110/334). Rumo aos extremos os sedimentos tornam-se pouco mais finos, principalmente ao norte. Teoricamente, isso deveria ocorrer no extremo sul, devido à influência do Canal da Bertioga e do Rio Itapanhaú. O grau de seleção no inverno aumentou sutilmente de sul para norte. No verão não foram verificadas tendências predominantes.

A "matriz de comparação" (quadro 34) mostra diferenças entre as etapas e também que, em ambas, o extremo norte comportou-se área deposicional. No extremo sul, os processos foram inversos, sendo deposicionais no inverno e erosivos no verão. No inverno foram reconhecidas duas grandes células de sentidos opostos, com centro de divergência 
no centro da praia (ponto 110), situado no trecho mais aberto para as ondas associadas a frentes frias, que se propagam de SSW-S-SSE. No verão, o centro de divergência ocorreu no ponto 333 , pouco mais a NE, também aberto para as ondas de sul, evidenciando provavelmente que ondas de frente fria atuando e deslocando o centro para o norte. Nesta etapa uma área deposicional foi encontrada no setor sul (ponto 335). Essas tendências são bastante semelhantes às observadas no sensoriamento remoto e no campo, onde processos erosivos foram também identificados (foto 11).

Os resultados obtidos com as ortogonais das ondas medidas no campo (tabela 11) também evidenciam semelhanças com os mostrados acima. No inverno, com tempo bom, verificou-se predomínio de ondas do quadrante SE, gerando transporte para SW. No verão, com frente fria, apareceram ondas de SW, predominando transportes para norte.

Portanto, o sentido de transporte na Praia de Bertioga parece ser dominantemente para SW durante as condições de tempo bom com ondas do quadrante SE, mas podem ser bidirecionais durante as frontogêneses, com ondas de SSW a SSE atingindo mais frontalmente o centro da praia e gerando derivas importantes para NE e SW.

Quadro 34: Matriz de comparação elaborada para a Praia de Bertioga

\begin{tabular}{|c|c|c|c|c|c|c|c|c|c|}
\hline \multirow[b]{2}{*}{$\begin{array}{l}\text { Etapa } \\
\text { de } \\
\text { Amost }\end{array}$} & \multirow[b]{2}{*}{$\begin{array}{l}\text { Perfil } \\
\text { Praial }\end{array}$} & \multicolumn{3}{|c|}{ PARÂM. TEXTURAIS } & \multicolumn{2}{|c|}{ MORFOLOGIA } & \multirow[b]{2}{*}{$\begin{array}{c}\text { Resultado } \\
\text { Final }\end{array}$} & \multirow[b]{2}{*}{$\begin{array}{c}\text { PROCESSO } \\
\text { E=erosão } \\
\mathrm{D}=\text { deposição } \\
\mathrm{T}=\text { transporte }\end{array}$} & \multirow[b]{2}{*}{$\begin{array}{c}\text { SENTIDO } \\
\text { DA } \\
\text { DERIVA }\end{array}$} \\
\hline & & $\begin{array}{c}\text { Diâmetro } \\
\text { Médio }\end{array}$ & $\begin{array}{c}\text { Grau } \\
\text { de } \\
\text { Seleção }\end{array}$ & $\begin{array}{c}\text { Curto- } \\
\text { se }\end{array}$ & $\begin{array}{l}\text { Incli- } \\
\text { nação }\end{array}$ & $\begin{array}{l}\text { Largu- } \\
\text { ra }\end{array}$ & & & \\
\hline \multirow{5}{*}{ INV. } & 108 & - & + & - & + & + & + & $\mathrm{D}$ & SW \\
\hline & 109 & $+/+$ & $-1-$ & $+/+$ & $-1+$ & $-1+$ & $-1+$ & $T$ & SW \\
\hline & 110 & $-1-$ & $+1-$ & $-1+$ & $-1-$ & $-1+$ & $-1-$ & $\mathrm{E}$ & SW/NE \\
\hline & 111 & $+1-$ & $+1-$ & $-1+$ & $+1-$ & $-1+$ & $+1-$ & $T$ & $\mathrm{NE}$ \\
\hline & 112 & + & + & - & + & - & + & $\mathrm{D}$ & $\mathrm{NE}$ \\
\hline \multirow{5}{*}{ VER. } & 336 & + & - & - & - & + & - & $\mathrm{E}$ & $\mathrm{NE}$ \\
\hline & 335 & $-1+$ & $+/ t+$ & $t / t$ & $+1+$ & $m /-$ & $+1+$ & $\mathrm{D}$ & NE/SW \\
\hline & 334 & $-1-$ & $-/+$ & $-1+$ & $-1 /$ & $+/+$ & $-1+$ & $\mathrm{T}$ & SW \\
\hline & 333 & $+/-$ & $-1-$ & $-1+$ & $+1-$ & $-1+$ & $-1-$ & $E$ & $\mathrm{SW} / \mathrm{NE}$ \\
\hline & 332 & + & + & - & + & - & + & $\mathrm{D}$ & NW \\
\hline
\end{tabular}




\section{- São Lourenço}

No inverno, a largura dessa praia aumentou progressivamente de sul para norte, enquanto no verão aumentou a partir do centro da praia, para o norte e para o sul. A inclinação também variou, sendo menor ao centro durante o inverno e maior nesse trecho, durante o verão. As larguras foram bem maiores no verão que no inverno, pois durante esta última atuava uma forte frente fria, enquanto que no verão havia calmaria (tabela 11).

Nesta praia foram encontradas apenas areias finas e muito bem selecionadas, sem ter havido variações entre as duas etapas de amostragem (figura 42). No inverno, 0 tamanho dos grãos mostrou-se ligeiramente menor no centro da praia, mas o grau de seleção aumentou de sul para norte. No verão não houve variações de granulometria, porém os graus de seleção foram relativamente maiores no centro da praia.

A "matriz de comparação" (quadro 35) permitiu reconhecer uma célula completa ao longo da praia, com barlamar no extremo SW e sotamar no extremo NE. No verão, a zona de barlamar estava no centro da praia e as zonas deposicionais nos dois extremos, portanto atuavam duas células divergentes. Essas variações provavelmente estão associadas a diferentes condições meteorológicas.

As medidas de ortogonais das ondas no campo (tabela 11) indicaram transportes opostos entre condições de frente fria (inverno), predominando rumo para sul, e tempo instável (final de frente fria no verão), com rumo para norte. Por outro lado, nas fotografias aéreas (tabela 10), obtidas provavelmente sob condições de tempo bom, o transporte predominante era dirigido para SW.

Quadro 35: Matriz de comparação obtida para a Praia de São Lourenço

\begin{tabular}{|c|c|c|c|c|c|c|c|c|c|}
\hline & \multicolumn{3}{|c|}{ PARÁM. TEXTURAIS } & \multicolumn{2}{|c|}{ MORFOLOGIA } & \multirow[b]{2}{*}{$\begin{array}{l}\text { Resultado } \\
\text { Final }\end{array}$} & \multirow[b]{2}{*}{$\begin{array}{c}\text { PROCESSO } \\
\text { E=erosão } \\
D=\text { deposição } \\
T=\text { transporte }\end{array}$} & \multirow[b]{2}{*}{$\begin{array}{c}\text { SENTIDO } \\
\text { DA } \\
\text { DERIVA }\end{array}$} \\
\hline $\begin{array}{l}\text { Etapa } \\
\text { de } \\
\text { Amost }\end{array}$ & $\begin{array}{l}\text { Perfil } \\
\text { Praial }\end{array}$ & $\begin{array}{c}\text { Diâmetro } \\
\text { Médio }\end{array}$ & $\begin{array}{c}\text { Grau } \\
\text { de } \\
\text { Seleçã } \\
0\end{array}$ & $\begin{array}{c}\text { Curto- } \\
\text { se }\end{array}$ & $\begin{array}{l}\text { Incli- } \\
\text { nação }\end{array}$ & $\begin{array}{l}\text { Largu- } \\
\text { ra }\end{array}$ & & & \\
\hline \multirow{3}{*}{ INV. } & 51 & + & - & - & - & - & - & $\mathrm{E}$ & $\mathrm{NE}$ \\
\hline & 50 & $-1-$ & $+1-$ & $+1+$ & $+/+$ & $+/-$ & $+1-$ & $\mathrm{T}$ & $\mathrm{NE}$ \\
\hline & 49 & + & + & - & - & + & + & $\mathrm{D}$ & $\mathrm{NE}$ \\
\hline \multirow{3}{*}{ VER. } & 329 & + & + & + & + & + & + & $\mathrm{D}$ & SW \\
\hline & 331 & $-m / m$ & $-1-$ & $-1+$ & $-1-$ & $-1-$ & $-1-$ & $E$ & SW/NE \\
\hline & 330 & + & + & - & + & + & + & $\mathrm{D}$ & $\mathrm{NE}$ \\
\hline
\end{tabular}


No extremo sul da praia um espigão foi parcialmente construído, para uma futura marina, mas a obra foi embargada. A presença desta estrutura já modificou a circulação local, de forma que pequenas células se formam ao redor dele, causando erosão na praia, principalmente na face sul do mesmo.

\section{- Itaguaré e Guaratuba}

Essas praias foram analisadas em conjunto porque constituem um segmento quase contínuo, interrompido pelo Rio itaguaré.

A largura praial aumenta das extremidades sul da Praia de Itaguaré e norte de Guaratuba, rumo às margens do Rio Itaguaré. As inclinações dos perfis, por outro lado, mostraram variações diferentes. No inverno, as maiores inclinações ocorreram ao sul de Itaguaré e diminuíram rumo ao rio. Em Guaratuba eram maiores junto ao rio e no centro da praia. No verão, as maiores inclinações também ocorreram nas proximidades do Rio Itaguaré em ambas as praias.

Nas praias de Itaguaré e Guaratuba predominam areias muito finas e finas, muito bem selecionadas (figuras $43 a$ e $43 b$ ).

Na Praia do Itaguaré verificou-se, do inverno para o verão, um incremento nas areias mais finas e diminuição do grau de seleção. No inverno $77,8 \%$ das areias eram finas e $22,2 \%$ muito finas, com $100 \%$ muito bem selecionadas. No verão foram obtidos $55,6 \%$ de areias finas e $44,4 \%$ de muito finas, com $77,8 \%$ muito bem selecionadas e $22,2 \%$ bem selecionadas. Em Guaratuba, por outro lado, as areias tornaram-se mais grossas e pior selecionadas no verão. No inverno $88,9 \%$ eram areias finas e o restante muito finas, com $100 \%$ muito bem selecionadas. No verão as areias passaram a finas (100\%), mas o grau de seleção variou entre os termos muito bem $(77,8 \%)$ e bem $(22,2 \%)$ selecionados.

Em ambas as praias foi possivel observar falésias em terraços marinhos holocênicos sotopostos por pequenas dunas inativas, caracterizando processos erosivos. Muros e blocos de rocha têm sido usados em vários trechos dessas praias para conter a erosão.

A "matriz de comparação" (quadro 36) não mostra variações importantes nas duas etapas de amostragem. Na Praia do Itaguaré foram identificadas duas células divergentes a partir do centro da praia, com sotamares nos seus extremos. Esses resultados estão de 
acordo com as observações de campo, pois o trecho central é o de maior energia de ondas (mais aberto para o mar) e a barra do Rio Itaguaré apresenta-se alongada e fortemente deslocada para ENE. Na Praia de Guaratuba obteve-se uma célula completa com barlamar no canto sul e sotamar ao norte, junto ao Rio Guaratuba, que também tem sua desembocadura deslocada para ENE. Neste trecho, foram observadas pequenas dunas embrionárias na pós-praia. $O$ transporte entre as duas praias parece ocorrer predominantemente da Praia de Guaratuba para a do Itaguaré, através de uma pequena célula local para WSW, a partir do extremo sul de Guaratuba. Esta célula local poderia explicar também o crescimento da barra praial de Guaratuba curvada para dentro do Rio Itaguaré.

As ortogonais das ondas medidas no campo (tabela 11) são indicativas de rumos semelhantes aos descritos acima, e também com os observados nas fotografias aéreas. No inverno, com frente fria e tempo instável, os rumos preferenciais foram para SW, mas variaram entre SW e NE no verão, em condições de tempo instável, ambos associados a ondas de SE.

Quadro 36: Matriz de comparação elaborada para as praias de Itaguaré e Guaratuba

\begin{tabular}{|c|c|c|c|c|c|c|c|c|c|}
\hline \multirow{2}{*}{$\begin{array}{c}\text { Etapa } \\
\text { de } \\
\text { Amost }\end{array}$} & \multirow[b]{2}{*}{$\begin{array}{l}\text { Perfil } \\
\text { Praial }\end{array}$} & \multicolumn{3}{|c|}{ PARÁM. TEXTURAIS } & \multicolumn{2}{|c|}{ MORFOLOGIA } & \multirow[b]{2}{*}{$\begin{array}{c}\text { Resultado } \\
\text { Final }\end{array}$} & \multirow[b]{2}{*}{$\begin{array}{c}\text { PROCESSO } \\
\text { E=erosão } \\
D=\text { deposição } \\
T=\text { transporte }\end{array}$} & \multirow[b]{2}{*}{$\begin{array}{c}\text { SENTIDO } \\
\text { DA } \\
\text { DERIVA }\end{array}$} \\
\hline & & $\begin{array}{c}\text { Diâmetro } \\
\text { Médio }\end{array}$ & $\begin{array}{c}\text { Grau } \\
\text { de } \\
\text { Seleção }\end{array}$ & $\begin{array}{l}\text { Curto- } \\
\text { se }\end{array}$ & $\begin{array}{l}\text { Incli- } \\
\text { nação }\end{array}$ & $\begin{array}{c}\text { Largu- } \\
\text { ra }\end{array}$ & & & \\
\hline \multirow{6}{*}{ INV. } & 48 & + & + & + & - & - & + & $\mathrm{D}$ & $\mathrm{SW}$ \\
\hline & 47 & $-1-$ & $-1-$ & $-1-$ & $+1-$ & $+1-$ & $-1-$ & $\mathrm{E}$ & SW/NE \\
\hline & 46 & $+1+$ & $+/+$ & $+1+$ & $t+t$ & $+1-$ & $+/+$ & $\mathrm{D}$ & $\mathrm{NE}$ \\
\hline & 44 & $-1 /-$ & $-1-$ & $-1-$ & -10 & $+/+$ & $-1-$ & $\mathrm{E}$ & $\mathrm{NE} / \mathrm{SW}$ \\
\hline & 42 & $+/-$ & $+1-$ & $+1-$ & $0 / m$ & $-1+$ & $+1-$ & $\mathrm{T}$ & $\mathrm{NE}$ \\
\hline & 41 & + & + & + & + & - & + & $\mathrm{D}$ & $\mathrm{NE}$ \\
\hline \multirow{6}{*}{ VER. } & 402 & + & + & + & + & - & + & $\mathrm{D}$ & $\overline{S W}$ \\
\hline & 401 & $-1-$ & $-1-$ & $-1-$ & $-1-$ & $+1-$ & $-1-$ & $\mathrm{E}$ & SW/NE \\
\hline & 400 & $+1+$ & $+1-$ & $t / t$ & $+/+$ & $+/+$ & $+1+$ & $\mathrm{D}$ & $\mathrm{NE}$ \\
\hline & 399 & $-1+$ & $+1-$ & $-1-$ & $-1-$ & $-1+$ & $-1-$ & $\mathrm{E}$ & $\mathrm{NE} / \mathrm{SW}$ \\
\hline & 398 & $-1-$ & $+1-$ & $+/+$ & $+1+$ & $-1-$ & $+1-$ & $\mathrm{T}$ & $\mathrm{NE}$ \\
\hline & 397 & + & + & - & - & + & + & $\mathrm{D}$ & $\mathrm{NE}$ \\
\hline
\end{tabular}




\section{- Boracéia}

Em Boracéia as larguras da praia mostraram-se maiores na porção central e os valores obtidos foram pouco maiores no verão. Os perfis apresentaram-se mais inclinados no verão, com valores maiores na porção central da praia.

Nesta praia (figura 44$)$ predominam areias muito finas $(72 \%)$, sendo o restante composto de areia fina, muito bem selecionadas (100\%).

Com a "matriz de comparação" (quadro 37) foi identificada uma célula completa no inverno, com barlamar no extremo oeste e sotamar no extremo oposto. No verão ocorreu convergência de duas células na porção central da praia, com barlamares nos seus extremos. No inverno com tempo bom, observou-se no campo maior energia no setor oeste da praia. Já no verão com tempo instável, isso foi observado no extremo leste. O pequeno rio que desemboca neste trecho está, em geral, deslocado para leste (SE).

As ortogonais de ondas medidas no campo (tabela 11) mostraram predominância de rumos do quadrante SE e correntes orientadas para WSW ao longo de toda a praia. As medidas feitas sobre as fotografias aéreas, provavelmente obtidas sob condições de calmaria, estão de acordo com esses resultados.

Deste modo, os dados obtidos no inverno parecem muito mais relacionados a condições de frente fria que de tempo bom. Isto pode significar que os depósitos não representavam as condições atuantes na época da amostragem.

Quadro 37: Matriz de comparação elaborada para a Praia de Boracéia

\begin{tabular}{|c|c|c|c|c|c|c|c|c|c|}
\hline \multirow[b]{2}{*}{$\begin{array}{l}\text { Etapa } \\
\text { de } \\
\text { Amost }\end{array}$} & \multirow[b]{2}{*}{$\begin{array}{l}\text { Perfil } \\
\text { Praial }\end{array}$} & \multicolumn{3}{|c|}{ PARÂM. TEXTURAIS } & \multicolumn{2}{|c|}{ MORFOLOGIA } & \multirow[b]{2}{*}{$\begin{array}{l}\text { Resultado } \\
\text { Final }\end{array}$} & \multirow[b]{2}{*}{$\begin{array}{c}\text { PROCESSO } \\
\text { E=erosão } \\
D=\text { deposição } \\
T=\text { transporte }\end{array}$} & \multirow[b]{2}{*}{$\begin{array}{c}\text { SENTIDO } \\
\text { DA } \\
\text { DERIVA }\end{array}$} \\
\hline & & $\begin{array}{l}\text { Diâmetro } \\
\text { Médio }\end{array}$ & $\begin{array}{c}\text { Grau } \\
\text { de } \\
\text { Seleção }\end{array}$ & $\begin{array}{c}\text { Curto- } \\
\text { se }\end{array}$ & $\begin{array}{l}\text { Incli- } \\
\text { nação }\end{array}$ & $\begin{array}{l}\text { Largu- } \\
\text { ra }\end{array}$ & & & \\
\hline \multirow{3}{*}{ INV. } & 142 & - & - & - & + & - & - & $E$ & ENE \\
\hline & 140 & $+/ t$ & $+/-$ & $+1-$ & $-1-$ & $+/ t$ & $+1-$ & $\mathrm{T}$ & ENE \\
\hline & 139 & - & + & + & + & -- & + & $\bar{D}$ & $\mathrm{ENE}$ \\
\hline \multirow{3}{*}{ VER. } & 396 & - & - & - & + & - & - & $\mathrm{E}$ & ENE \\
\hline & 395 & $+1+$ & $+1+$ & $+1+$ & $-1-$ & $+1+$ & $+1+$ & $\bar{D}$ & ENE/SSW \\
\hline & 394 & - & - & - & + & - & - & $\mathrm{E}$ & WSW \\
\hline
\end{tabular}




\section{- Juquehy}

Ao longo da Praia de Juquehy as variações morfológicas observadas são bem mais notáveis que nas demais praias ao sul, devido ao seu estado morfodinâmico intermediário. Nas proximidades do Rio Juquehy a largura da praia é maior e a inclinação bem menor que no restante. Na porção centro-oeste da praia, a presença de pequenas ilhas próximas à costa propicia o desenvolvimento de cúspides amplas e inclinadas, devido à difração/refração das ondas nessas ilhas. Este é o trecho de maior energia da praia, estando mais frontal às ondas de S, SSE e SSW. Além dessas pequenas ilhas, outras ilhas maiores também ocorrem pouco mais afastadas da praia, aumentando as interferências nos trens de ondas que atingem a costa. Portanto, pequenas células locais devem ocorrer ao longo da maior parte desta praia. Somam-se a essas interferências naturais, as geradas pelo homem, como os muros das casas que margeiam toda a pós-praia.

Embora predominem areias finas $(55,6 \%)$, as areias médias são também importantes $(33,3 \%)$, principalmente no setor centro-oeste (figura 45). Areias muito finas $(11,1 \%)$ ocorrem nas proximidades do Rio Juquehy. $O$ grau de seleção é predominantemente bom $(66,6 \%)$, mas também ocorrem os termos moderados, principalmente no trecho centro-oeste da praia. Portanto, de oeste para leste há diminuição do tamanho e aumento do grau de seleção dos sedimentos.

A "matriz de comparação" (quadro 38) mostra, nas duas etapas de amostragem, uma célula completa com barlamar no extremo $W$ e sotamar junto ao Rio Juquehy, como esperado. Mas as circulação desta praia não deve ser assim tão simples devida à presença de ithas nas suas proximidades, resultando em padrão complexo de incidência de ondas junto à praia e, portanto, pequenas células de deriva litorânea. Isto é evidenciado pela presença de cúspide praias ao longo da mesma. Os resultados obtidos refletiriam transportes resultantes.

Embora as ortogonais de ondas tenham sido medidas sob condições de tempo bom nas duas etapas de amostragem (tabela 11), a maioria dos valores correspondem a ondas de SSW a SSE, assim como as obtidas nas fotografias aéreas (tabela 10). Essas variações de direção resultam, provavelmente da forte interferência que as ondas sofrem ao atingirem a costa. 
Quadro 38: Matriz de comparação elaborada para a Praia do Juquehy

\begin{tabular}{|c|c|c|c|c|c|c|c|c|c|}
\hline & \multicolumn{3}{|c|}{ PARÁM. TEXTURAIS } & \multicolumn{2}{|c|}{ MORFOLOGIA } & \multirow[b]{2}{*}{$\begin{array}{l}\text { Resultado } \\
\text { Final }\end{array}$} & \multirow[b]{2}{*}{$\begin{array}{c}\text { PROCESSO } \\
\text { E=erosão } \\
\text { D=deposição } \\
T=\text { transporte }\end{array}$} & \multirow[b]{2}{*}{$\begin{array}{c}\text { SENTIDO } \\
\text { DA } \\
\text { DERIVA }\end{array}$} \\
\hline $\begin{array}{c}\text { Etapa } \\
\text { de } \\
\text { Amost }\end{array}$ & $\begin{array}{l}\text { Perfil } \\
\text { Praial }\end{array}$ & $\begin{array}{l}\text { Diâmetro } \\
\text { Médio }\end{array}$ & $\begin{array}{c}\text { Grau } \\
\text { de } \\
\text { Seleção }\end{array}$ & $\begin{array}{l}\text { Curto- } \\
\text { se }\end{array}$ & $\begin{array}{l}\text { Incli- } \\
\text { nação }\end{array}$ & $\begin{array}{l}\text { Largu- } \\
\text { ra }\end{array}$ & & & \\
\hline \multirow{3}{*}{ INV. } & 135 & - & - & + & - & - & - & $\mathrm{E}$ & ENE \\
\hline & 134 & $+1-$ & $+1-$ & $-1-$ & $+1-$ & $+1-$ & $+1-$ & $T$ & $\overline{\mathrm{ENE}}$ \\
\hline & 133 & + & + & + & + & + & + & $\mathrm{D}$ & ENE \\
\hline \multirow{3}{*}{ VER. } & 447 & - & - & - & + & + & - & $\mathrm{E}$ & ENE \\
\hline & 448 & $+/-$ & $+1-$ & $+1-$ & $-1-$ & $-1-$ & $+1-$ & $\mathrm{T}$ & ENE \\
\hline & 449 & + & + & + & + & + & + & $\bar{D}$ & ENE \\
\hline
\end{tabular}

\section{- Baleia}

Nesta praia as larguras medidas mostraram-se muito semelhantes, tanto no inverno como no verão, excetuando-se o perfil central, que se apresentou mais estreito no inverno. Os perfis de maior declividade ocorreram na porção central da praia. Neste local foram medidas a maior e a menor inclinação da antepraia, respectivamente, no inverno e no verão.

Não foram observadas variações de granulometria ou de grau de seleção entre as duas etapas de amostragem (figura 46). Nessa praia predominam areias finas $(77,8 \%$ ) e muito bem selecionadas $(88,9 \%)$, seguidas das areia muito finas $(22,2 \%)$ e bem selecionadas $(11,1 \%)$. Em geral, a granulometria decresce e o grau de seleção aumenta de oeste para leste da praia.

Com a "matriz de comparação" (quadro 39) foi possivel visualizar, no inverno, duas células divergentes no centro da praia, com sotamares nas extremidades. No verão foi identificada uma célula completa, com barlamar no extremo oeste e sotamar a leste. As zonas de barlamar encontradas estão de acordo com os maiores niveis de energia da praia observados no campo, em cada época de amostragem. Os resultados obtidos no inverno estão mais de acordo com os obtidos a partir da análise de produtos de sensoriamento remoto. 
Quadro 39: Matriz de comparação elaborada para a Praia da Baleia

\begin{tabular}{|c|c|c|c|c|c|c|c|c|c|}
\hline & & PARAMM & TEXTUI & AIS & MORF & LOGIA & & & \\
\hline $\begin{array}{c}\text { Etapa de } \\
\text { Amost }\end{array}$ & $\begin{array}{l}\text { Perfil } \\
\text { Praial }\end{array}$ & $\begin{array}{l}\text { Diâmetro } \\
\text { Médio }\end{array}$ & $\begin{array}{c}\text { Grau } \\
\text { de } \\
\text { Seleção }\end{array}$ & $\begin{array}{l}\text { Curto- } \\
\text { se }\end{array}$ & $\begin{array}{l}\text { Incli- } \\
\text { nação }\end{array}$ & $\begin{array}{l}\text { Largu- } \\
\text { ra }\end{array}$ & $\begin{array}{c}\text { Resultado } \\
\text { Final }\end{array}$ & $\begin{array}{c}\text { PROCESSO } \\
\text { E=erosão } \\
\mathrm{D}=\text { deposição } \\
\mathrm{T}=\text { transporte }\end{array}$ & $\begin{array}{c}\text { SENTIDO } \\
\text { DA } \\
\text { DERIVA }\end{array}$ \\
\hline & 131 & - & - & + & + & + & + & $\mathrm{D}$ & WSW \\
\hline INV. & 130 & $+1-$ & $+1-$ & $-1-$ & $-1-$ & $-1-$ & $-1-$ & $E$ & WSW/NE \\
\hline & 129 & + & + & + & + & + & + & $\mathrm{D}$ & ENE \\
\hline & 450 & - & - & - & - & - & - & $\mathrm{E}$ & $\overline{\mathrm{ENE}}$ \\
\hline VER. & 451 & $+1-$ & $+1-$ & $+1-$ & $+1+$ & $t / t$ & $+1-$ & $T$ & $\mathrm{ENE}$ \\
\hline & 452 & + & + & + & - & - & + & $\bar{D}$ & ENE \\
\hline
\end{tabular}

Os dados de ortogonais de ondas medidos no campo (tabela 11) indicam transporte para WSW nas duas etapas, ambas executadas em condições de tempo bom. Os valores medidos representam o produto final de muitas interferências que os trens de ondas sofrem ao se aproximar da costa.

\section{- Boiçucanga}

Esta praia exibe características mistas entre intermediária e reflexiva, sendo a mais reflexiva de todo o setor $\mathrm{V}$.

As menores larguras foram encontradas na porção central da praia, no inverno, e no extremo leste no verão. As maiores declividades da antepraia foram medidas no inverno, quando atuava uma forte frente fria que provocou o desenvolvimento de elevadas bermas, principalmente no canto $W$ da praia (foto 13 ). No verão, em condições de tempo bom, a variação foi inversa com maior inclinação no extremo leste e menor no oeste.

Variações texturais também foram constatadas entre as etapas de amostragem (figura 47). No inverno, predominaram areias grossas $(66,7 \%)$ e bem selecionadas $(88,9 \%)$, seguidas das areias médias $(33,3 \%)$ e moderadamente selecionadas $(11,1 \%)$. No verão, houve ligeira diminuição do tamanho e também do grau de seleção: $56,6 \%$ de areias grossas e $44,4 \%$ de areias médias, com $77,8 \%$ de termos moderadamente selecionados e $11,1 \%$ de bem e pobremente selecionados.

A "matriz de comparação" (quadro 40) mostrou, para ambas as etapas, a presença de duas células completa. No inverno, sob condições de frente fria, a zona de barlamar encontrava-se no extremo oeste e a de sotamar no extremo leste; no verão, com tempo 
bom, a zona de barlamar localizava-se no extremo leste e a de sotamar no extremo oposto. Portanto, foram caracterizados dois sentidos opostos de deriva, para condições meteorológicas antagônicas, isto é, para $E$ durante as frentes frias e para $W$ em tempo bom. Entretanto, esta praia também desenvolve pequenas células de deriva litorânea, 0 que é sugerido em função da presença de cúspides praiais durante o ano todo.

Quadro 40: Matriz de comparação elaborada para a Praia de Boiçucanga

\begin{tabular}{|c|c|c|c|c|c|c|c|c|c|}
\hline & \multicolumn{3}{|c|}{ PARÁM. TEXTURAIS } & \multicolumn{2}{|c|}{ MORFOLOGIA } & \multirow[b]{2}{*}{$\begin{array}{l}\text { Resultado } \\
\text { Final }\end{array}$} & \multirow[b]{2}{*}{$\begin{array}{c}\text { PROCESSO } \\
\text { E=erosão } \\
D=\text { deposição } \\
T=\text { transporte }\end{array}$} & \multirow[b]{2}{*}{$\begin{array}{c}\text { SENTIDO } \\
\text { DA } \\
\text { DERIVA }\end{array}$} \\
\hline $\begin{array}{c}\text { Etapa } \\
\text { de } \\
\text { Amost }\end{array}$ & $\begin{array}{l}\text { Perfil } \\
\text { Praial }\end{array}$ & $\begin{array}{l}\text { Diâmetr } \\
\text { o Médio }\end{array}$ & $\begin{array}{l}\text { Grau } \\
\text { de } \\
\text { Seleção }\end{array}$ & $\begin{array}{l}\text { Curto- } \\
\text { se }\end{array}$ & $\begin{array}{l}\text { Incli- } \\
\text { nação }\end{array}$ & $\begin{array}{l}\text { Largu- } \\
\text { ra }\end{array}$ & & & \\
\hline \multirow{3}{*}{ INV. } & 126 & - & - & - & - & + & - & $\mathrm{E}$ & $\mathrm{ENE}$ \\
\hline & 125 & $+1-$ & $+/ t$ & $+1-$ & $+1-$ & $-1-$ & $+1-$ & $\mathrm{T}$ & ENE \\
\hline & 124 & + & - & + & + & + & + & $\mathrm{D}$ & ENE \\
\hline \multirow{3}{*}{ VER. } & 453 & + & - & - & + & + & + & $\mathrm{D}$ & WSW \\
\hline & 454 & $-1-$ & $+1+$ & $+1-$ & $-1+$ & $-1+$ & $-1+$ & $T$ & WSW \\
\hline & 455 & + & - & + & - & - & - & $\mathrm{E}$ & WSW \\
\hline
\end{tabular}

Os sinais positivos obtidos para o grau de seleção das amostras 124 e 453 provavelmente podem ser atribuídos ao aporte de sedimentos novos à praia, através do Rio Boiçucanga, ou provenientes da erosão do fundo marinho adjacente.

Os resultados de transporte estariam de acordo com o esperado, pois a costa é mais aberta e tem orientação $\approx \mathrm{EW}$. As ondas associadas às frentes frias, propagando-se de SSW-S-SSE, atingem mais frontalmente o extremo oeste de Boiçucanga, em ângulos voltados para leste e, conseqüentemente, derivas com este rumo. Em condições de tempo bom as ondas de SE-ESE atingem primeiramente a porção leste da praia, com ângulos são voltados para oeste e gerando derivas com este sentido. O transporte para $W$ também é notado nas fotografias aéreas, obtidas sob condições de tempo bom.

Cúspides praiais bem desenvolvidas e regularmente espaçadas são normalmente observadas em toda a praia, sugerindo maior complexidade de processos e a presença de pequenas células. Isso pode ser verificado, por exemplo, no extremo leste da praia, onde normalmente há o deslocamento da barra praial do Rio Boiçucanga, para leste, sendo portanto zona de sotamar. 


\section{- Maresias}

As cúspides e a barra de deriva litorânea interrompida sempre presentes nesta praia, sugerem a presença de pequenas células e de canais com correntes de retorno (foto 12). Esta praia é, sem dúvida, o mais belo exemplo de tipo intermediário no Estado de São Paulo.

No inverno verificou-se ligeira diminuição de largura praial de oeste para leste, enquanto no verão, as tendências foram inversas. Os perfis de maior declividade foram encontrados no setor central da praia, embora os valores obtidos para a antepraia tenham sido maiores neste trecho apenas durante o inverno, sendo maior no extremo oeste durante o verão.

Em geral, foi verificado ligeiro afinamento das areias e diminuição do grau de seleção, do inverno para o verão (figura 48 ). No inverno, $77,8 \%$ eram de areias médias e $22,2 \%$ de areias grossas, com $66,7 \%$ de termos muito bem selecionados e o restante $(33,3 \%)$ moderadamente selecionados. No verão, as areias médias atingiram $88,9 \%$, restando apenas $11,1 \%$ de areias grossas e os graus de seleção indicaram $55,6 \%$ de bem selecionados e $44,4 \%$ de moderadamente selecionados.

A "matriz de comparação" (quadro 41) também revelou tendências diferenciadas entre o inverno e o verão. Uma célula completa com barlamar no extremo oeste e sotamar no extremo oposto foi identificada no inverno, enquanto que no verão, duas células divergentes foram encontradas no centro da praia. Como foi verificado no campo e confirmado com esses resultados, o extremo leste da praia é sempre zona de sotamar, havendo sempre um forte deslocamento da barra praial para leste. Assim, como foi dito acima, embora tenham sido identificadas tendências resultantes de transporte, a circulação nesta praia deve ser mais complexa. Processos erosivos foram observados no extremo oeste da praia (vide capítulo VII), onde ocorre um grande embaiamento (foto 12) associado à zona de barlamar identificada no quadro abaixo e também a correntes de retorno.

O sinal negativo obtido para o grau de seleção da amostra 121 poderia estar relacionado a sua proximidade do Rio Maresias.

As ortogonais de ondas medidas no campo (tabela 11) mostraram transportes com sentidos opostos entre o inverno com frente fria e o verão com tempo bom, com rumos de ondas predominantemente de SW no primeiro e SE no segundo caso. 
Os dados obtidos estão coerentes com as variações de incidência de ondas relacionadas às frentes frias.

Quadro 41: Matriz de comparação elaborada para a Praia de Maresias

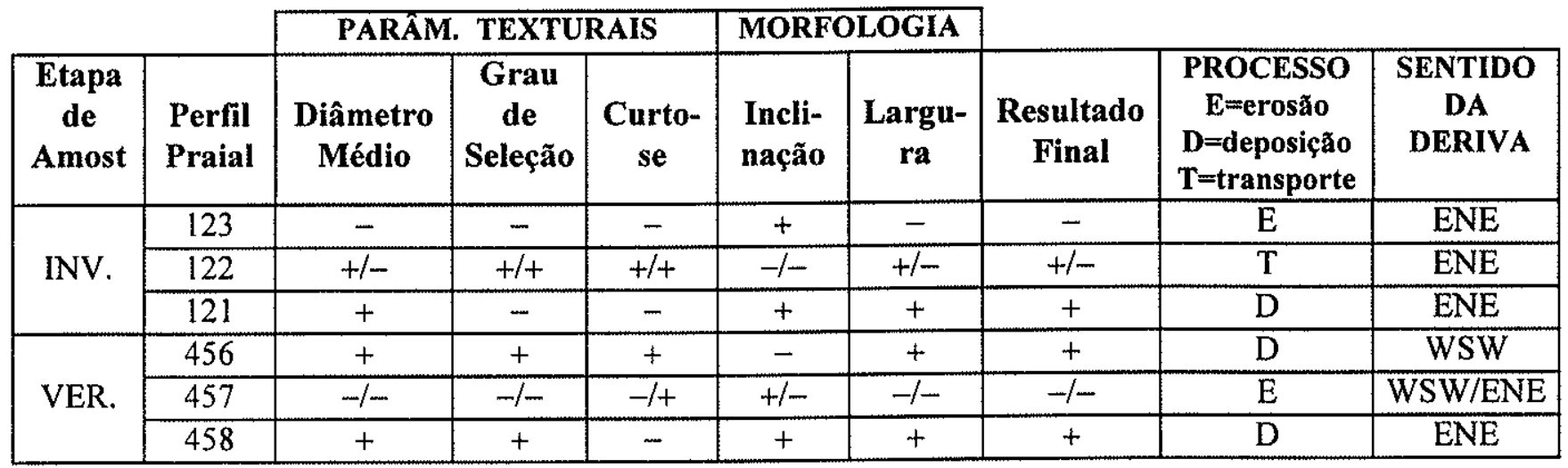

\section{- Santiago e Toque-Toque Pequeno}

Essas duas praias foram estudadas juntas pois representam um segmento quase contínuo, onde a maior energia de ondas sem dúvida ocorre em Toque-Toque Pequeno, que se caracteriza como praia mais inclinada e mais estreita.

Na Praia de Santiago predominaram areias médias e moderadamente selecionadas no verão, mas no inverno ocorreram também areias finas $(33,3 \%$ ) (figura 49 ).

Em Toque-Toque as areias mostraram-se grossas (100\%) e moderadamente selecionadas (100\%) durante o inverno (figura 49). O grau de seleção não variou mas houve um afinamento nas areias que se tornaram predominantemente médias $(66,7 \%)$, seguidas das grossas $(33,3 \%)$, durante o verão.

A "matriz de comparação" (quadro 42) mostrou que nas duas etapas de amostragem predominaram transportes para NW, com zonas de barlamar nos extremos SE das duas praias e sotamares nos respectivos extremos NW.

As medidas das ortogonais de ondas (tabela 11) sugerem transportes para NW no inverno (frente fria) e para SE no verão (tempo bom). Nas fotografias aéreas (tabela 10), os rumos NW também predominaram. Essas variações podem estar associadas a células menores, não identificadas aqui devido ao espaçamento das amostragens.

Quadro 42: Matriz de comparação elaborada para as praias de Santiago e Toque-Toque Pequeno 


\begin{tabular}{|c|c|c|c|c|c|c|c|c|c|}
\hline & \multicolumn{3}{|c|}{ PARÁM. TEXTURAIS } & \multicolumn{2}{|c|}{ MORFOLOGIA } & \multirow[b]{2}{*}{$\begin{array}{c}\text { Resultado } \\
\text { Final }\end{array}$} & \multirow[b]{2}{*}{$\begin{array}{c}\text { PROCESSO } \\
\text { E=erosão } \\
\text { D=deposição } \\
T=\text { transporte }\end{array}$} & \multirow[b]{2}{*}{$\begin{array}{c}\text { SENTIDO } \\
\text { DA } \\
\text { DERIVA }\end{array}$} \\
\hline $\begin{array}{l}\text { Etapa } \\
\text { de } \\
\text { Amost }\end{array}$ & $\begin{array}{l}\text { Perfil } \\
\text { Praial }\end{array}$ & $\begin{array}{c}\text { Diâmetro } \\
\text { Médio }\end{array}$ & $\begin{array}{c}\text { Grau } \\
\text { de } \\
\text { Seleção }\end{array}$ & $\begin{array}{c}\text { Curto- } \\
\text { se }\end{array}$ & $\begin{array}{l}\text { Incli- } \\
\text { nação }\end{array}$ & $\begin{array}{l}\text { Largu- } \\
\text { ra }\end{array}$ & & & \\
\hline \multirow[t]{2}{*}{ INV. } & 120 & + & + & - & + & - & + & $\mathrm{D}$ & NW \\
\hline & 119 & - & - & + & - & + & - & $E$ & NW \\
\hline \multirow[t]{2}{*}{ VER. } & 459 & + & - & - & + & + & + & $\mathrm{D}$ & NW \\
\hline & 460 & - & + & + & - & - & - & $E$ & $\mathrm{NW}$ \\
\hline
\end{tabular}

O sinal negativo obtido para o grau de seleção da amostra 459 poderia estar relacionado a sua proximidade do rio que desemboca no local e cujo canal migra continuamente.

\section{- Guaecá}

Nesta praia as larguras foram maiores e as inclinações menores no verão e contrariamente, as larguras apresentaram-se menores e as inclinações maiores no inverno, devido à frente fria que atuava nesta época, propiciando o desenvolvimento de bermas e cúspides elevadas. Os maiores valores de inclinação da antepraia ocorreram na sua porção central.

A granulometria e os graus de seleção das areias variaram entre as duas etapas de amostragem (figura 50$)$, com areias médias $(58,4 \%)$ e finas $(33,3 \%)$, moderadamente selecionadas $(91,7 \%)$ durante o inverno, e areias finas $(58,3 \%)$ e médias $(41,7 \%)$, bem selecionadas $(75 \%)$ no verão.

Com a "matriz de comparação" (quadro 43) foram identificadas, no inverno, duas células divergentes a partir de setor centro-sul da praia (ponto 116) e uma célula com barlamar no extremo noroeste (ponto 117). No verão, uma célula completa foi identificada, com barlamar no extremo noroeste (ponto 464) e sotamar no lado oposto (ponto 461). Como foi observado no campo, o extremo noroeste da praia é o de maior energia, pois é o mais aberto para as ondas de SSW-S-SSE, estando os resultados obtidos de acordo com esta situação. 
Quadro 43: Matriz de comparação elaborada para a Praia do Guaecá

\begin{tabular}{|c|c|c|c|c|c|c|c|c|c|}
\hline \multirow[b]{2}{*}{$\begin{array}{c}\text { Etapa } \\
\text { de } \\
\text { Amost }\end{array}$} & \multirow[b]{2}{*}{$\begin{array}{l}\text { Perfil } \\
\text { Praial }\end{array}$} & \multicolumn{3}{|c|}{ PARÁM. TEXTURAIS } & \multicolumn{2}{|c|}{ MORFOLOGIA } & \multirow[b]{2}{*}{$\begin{array}{l}\text { Resultado } \\
\text { Final }\end{array}$} & \multirow[b]{2}{*}{$\begin{array}{c}\text { PROCESSO } \\
\mathrm{E}=\text { erosăo } \\
\mathrm{D}=\text { deposição } \\
\mathrm{T}=\text { transporte }\end{array}$} & \multirow[b]{2}{*}{\begin{tabular}{|c|} 
SENTIDO \\
DA \\
DERIVA
\end{tabular}} \\
\hline & & $\begin{array}{l}\text { Diâmetro } \\
\text { Médio }\end{array}$ & $\begin{array}{c}\text { Grau } \\
\text { de } \\
\text { Seleção }\end{array}$ & $\begin{array}{c}\text { Curto- } \\
\text { se }\end{array}$ & $\begin{array}{l}\text { Incli- } \\
\text { nação }\end{array}$ & $\begin{array}{c}\text { Largu- } \\
\text { ra }\end{array}$ & & & \\
\hline \multirow{4}{*}{ INV. } & 117 & - & - & - & - & - & - & $\mathrm{E}$ & NW \\
\hline & 118 & $t / t$ & $+/+$ & $+/ t$ & $+1+$ & $+/+$ & $t / t$ & $\mathrm{D}$ & NW/SE \\
\hline & 116 & $-1-$ & $-1-$ & $-1-$ & $-1-$ & -10 & $-1-$ & $\bar{E}$ & NW/SE \\
\hline & 115 & + & + & + & + & 0 & + & $\mathrm{D}$ & $\mathrm{SE}$ \\
\hline \multirow{4}{*}{ VER. } & 464 & - & - & - & - & - & - & $\mathrm{E}$ & $\mathrm{SE}$ \\
\hline & 463 & $+1-$ & $+/ t$ & $+1-$ & $+1-$ & $+1+$ & $+1-$ & $\mathrm{T}$ & $\mathrm{SE}$ \\
\hline & 462 & $+1-$ & $-1-$ & $+1+$ & $+1+$ & $-1-$ & $+1-$ & $\mathrm{T}$ & $\overline{\mathrm{SE}}$ \\
\hline & 461 & + & + & - & - & + & + & $\mathrm{D}$ & $\mathrm{SE}$ \\
\hline
\end{tabular}

As medidas de ortogonais de ondas feitas no campo (tabela 11) refletem as diferentes condições meteorológicas que atuavam no inverno, com frente fria, e no verão, com tempo instável.

\section{- Barequeçaba}

Nessa praia apenas duas amostras foram coletadas.

As larguras praiais medidas no verão foram bem maiores e as inclinações menores que no inverno, fato explicável pela maré de quadratura e pela frente fria que atuavam durante o inverno, em contraposição à baixamar de sizígia e ao tempo instável encontrados no verão. Os perfis levantados no extremo noroeste da praia apresentaram maiores declividades.

Embora sempre predominem areias muito finas, elas estavam mais grossas no inverno (figura 51). Na etapa de inverno foi obtida a seguinte distribuição: $50 \%$ de areias muito finas, $33,3 \%$ de areias finas e $16,7 \%$ de areias médias, com $50 \%$ de termos pobremente selecionados, $33,3 \%$ de muito bem selecionados, e $16,7 \%$ de moderadamente selecionados. No verão apareceram apenas areias muito finas, com distribuições entre termos moderadamente $(50 \%)$, bem $(33,3 \%)$ e muito bem selecionados $(16,7 \%)$. As areias mais grossas e pior selecionadas foram encontradas no canto noroeste da praia, onde a energia das ondas é relativamente menor. 
Com a "matriz de comparação" (quadro 44) foram identificados, para as duas etapas, transportes de NW para SE, ou seja, uma célula com barlamar no extremo noroeste e sotamar a sudeste. Esses resultados estão de acordo com as observações de campo em relação à energia relativamente maior da praia e à erosão mais no extremo noroeste (foto 14).

Quadro 44: Matriz de comparação elaborada para a Praia de Barequeçaba

\begin{tabular}{|c|c|c|c|c|c|c|c|c|c|}
\hline & \multicolumn{3}{|c|}{ PARÁM. TEXTURAIS } & \multicolumn{2}{|c|}{ MORFOLOGIA } & \multirow[b]{2}{*}{$\begin{array}{l}\text { Resultado } \\
\text { Final }\end{array}$} & \multirow[b]{2}{*}{$\begin{array}{c}\text { PROCESSO } \\
\mathrm{E}=\text { erosão } \\
\mathrm{D}=\text { deposição } \\
\mathrm{T}=\text { transporte }\end{array}$} & \multirow[b]{2}{*}{$\begin{array}{c}\text { SENTIDO } \\
\text { DA } \\
\text { DERIVA }\end{array}$} \\
\hline $\begin{array}{c}\text { Etapa } \\
\text { de } \\
\text { Amost }\end{array}$ & $\begin{array}{l}\text { Perfil } \\
\text { Praial }\end{array}$ & $\begin{array}{c}\text { Diâmetro } \\
\text { Médio }\end{array}$ & $\begin{array}{c}\text { Grau } \\
\text { de } \\
\text { Seleção }\end{array}$ & $\begin{array}{l}\text { Curto- } \\
\text { se }\end{array}$ & $\begin{array}{l}\text { Incli- } \\
\text { nação }\end{array}$ & $\begin{array}{l}\text { Largu- } \\
\text { ra }\end{array}$ & & & \\
\hline \multirow[t]{2}{*}{ INV. } & 114 & - & - & + & - & + & - & $\mathrm{E}$ & $\mathrm{SE}$ \\
\hline & 113 & + & + & - & + & - & + & $\mathrm{D}$ & $\mathrm{SE}$ \\
\hline \multirow[t]{2}{*}{ VER. } & 465 & - & - & + & - & - & - & $\mathrm{E}$ & $\mathrm{SE}$ \\
\hline & 466 & + & + & - & + & + & + & $\mathrm{D}$ & $\mathrm{SE}$ \\
\hline
\end{tabular}

As ortogonais de ondas medidas no campo (tabela 11) mostraram sentidos de transporte semelhantes aos obtidos no verão, cujas condições eram de tempo instável.

\section{5. 3. MÉTOdo DE MCLAREN}

Os quadros 45 e 46 (Volume II) mostram que nos resultados obtidos para o setor $\mathrm{V}$ as tendências foram semelhantes entre o inverno e o verão, como são comentadas abaixo. (a) As correlações positivas no inverno atingiram cerca de $28,7 \%$ do total e, no verão, $23,6 \%$.

(b) Os transportes rumo ao Canal da Bertioga (SN/SW/NW) predominaram nas duas etapas de amostragem, com $83,2 \%$ no inverno (Z-estatístico $=28,340$ ) e $76,5 \%$ no verão (Z-estatístico $=18,520)$. Os transportes no sentido oposto, rumo ao Canal de São Sebastião, atingiram freqüências baixas e Z-estatísticos negativos.

(c) Os casos B foram os mais comuns, correspondendo a $85,4 \%$ no inverno e $74,6 \%$ no verão. Desses casos, somente os associados ao transportes para o sul atingiram niveis de significância estatistica, Z- Binv $(S)=22,290$ e Z- Bver $(S)=12,650$.

(d) Se os casos "A" fossem computados, mesmo assim ainda prevaleceriam os transportes para o sul. 
(e) Observando os dois quadros nota-se que as praias ao sul do setor, entre Bertioga e Boracéia, pouco contribuem como áreas-fonte para as praias ao norte. Os transportes para norte começam a ocorrer somente a partir de Juquehy, sendo mais importantes na Praia de Boiçucanga.

(f) Portanto, se predominam os transportes para sul, então são mais efetivos os sistemas associados a condições de tempo bom, com ondas de SE e ESE, do que os produzidos pelas frentes frias, que implicariam em transportes para o norte.

(g) A Praia de Boiçucanga funciona com área-fonte para a maioria das praias ao norte e ao sul, mas tem poucas fontes locais.

\section{4. 4. CONCLUSÕES}

Em geral, verificou-se boa correlação entre os três métodos utilizados. O quadro 47 mostra as distribuições percentuais de transporte obtidas pelos métodos utilizados. Os dados de ondas obtidos nas fotografias aéreas de 1962 não foram computados.

Quadro 47. Comparação entre os resultados percentuais dos rumos de transporte obtidos a partir dos diferentes métodos utilizados.

\begin{tabular}{|c|c|c|c|c|}
\cline { 2 - 5 } \multicolumn{1}{c|}{} & \multicolumn{2}{c|}{ INVERNO } & \multicolumn{2}{c|}{ VERÃO } \\
\cline { 2 - 5 } \multicolumn{1}{c|}{} & \multicolumn{2}{c|}{ TRANSPORTE } & $61,4 \%$ & $38,6 \%$ \\
\hline MÉTODO & N/E/NE/SE & SWW/SW/NW & N/E/NE/SE & SWW/SW/NW \\
\hline Taggart \& Schwartz-modif. & $69,8 \%$ & $30,2 \%$ & $13,5 \%$ & $76,5 \%$ \\
\hline McLaren & $16,8 \%$ & $83,2 \%$ & $51,4 \%$ & $48,6 \%$ \\
\hline Ondas - Campo & $32,6 \%$ & $67,4 \%$ & $36,4 \%$ & $63,6 \%$ \\
\hline Ondas - Fotos Aéreas & $37,5 \%$ & $62,5 \%$ & & \\
\hline
\end{tabular}

Os resultados de medições das ortogonais de ondas, no campo e nas fotografias aéreas, forneceram informações semelhantes. Deve-se enfatizar que os dados de ondas obtidos no campo são representativos de várias condições meteorológicas no inverno e 
verão. No inverno, $47,7 \%$ das medidas estiveram associadas ao tempo bom, $45,5 \%$ a condições de frente fria e $6,8 \%$ a tempo instável (final de frente fria). No verão, por outro lado, $48,7 \%$ das medidas correspondem a condições de tempo instável, $37,8 \%$ ao tempo bom; e $13,5 \%$ a condições de frentes frias. Essas situações explicam porque, aparentemente, os resultados de ondas foram inversos aos obtidos pelo método de TAGGART \& SCHWARTZ-modificado. Além disso, talvez expliquem as relaçōes inversas aos dados de ondas obtidos nas fotografias aéreas para os meses de verão, sempre com tempo bom.

O método de MCLAREN indica que os sistemas de transporte entre as praias desse setor são mais efetivos sob a atuação de condições de tempo bom, com ondas de SE e ESE, do que os relacionados a frentes frias, que implicariam em transportes rumo ao Canal de São Sebastião.

No entanto, pelo método de TAGGART \& SCHWARTZ-modificado, que representa individualmente as praias, verificou-se a predominância dos transportes para norte, sugerindo que na maioria das vezes os registros sedimentares representam condições de frente fria com tempo instável. No inverno, sete das doze praias foram amostradas sob condições de frente fria, uma em tempo instável, e quatro com tempo bom. No verão, por outro lado, seis praias foram amostradas sob condições de instabilidade, uma sob frente fria e cinco com tempo bom. Essas condições poderiam explicar porque os transportes para norte foram mais importantes do que para sul.

Os resultados apresentados sugerem que os dois sentidos de transporte são importantes no setor $V$, mas que sob condições meteorológicas diferenciadas, um pode predominar sobre o outro. Deste modo, durante as frentes frias, os transportes resultantes dentro de cada praia são geralmente dirigidos para leste, rumo ao canal de São Sebastião. Esta parece ser também a situação em condições de tempo instável. Durante as calmarias, os transportes resultantes retornam para o lado oposto. Obviamente, essas relações são dependentes também da orientação de cada praia em relação às ondas de SSW-S-SSE e SE-ESE.

As mudanças texturais observadas em algumas praias, entre uma etapa de amostragem e a outra, podem estar relacionadas aos mesmos processos descritos no setor morfodinâmico IV (item VI. 4.4). 
PONÇANO et al. (1994, in NAKAZAWA, et al.,1994) propuseram para este segmento de costa a predominância de transportes costa adentro-costa afora e, localmente, derivas de rumo $W$ e $E$ (figura 3 ). Deste modo, apenas parte de seus resultados estão de acordo com os aqui obtidos. Por outro lado, chama atenção o fato de os autores atribuirem a predominância de transportes costa adentro e costa afora no trecho entre o Rio Una e Canal de São Sebastião, pois é nele que as praias do setor $V$ apresentam estados morfodinâmicos caracteristicamente mais intermediários a reflexivos como, por exemplo, em Juquehy, Sahy, Cambury, Camburizinho, Boiçucanga, Maresias, Paúba, Santiago, Toque-Toque Pequeno e Guaecá. Obviamente, esses estados morfodinâmicos estão associados à costa mais recortada e à presença de várias ilhas, o que tornaria pouco provável a predominância de dinâmica costa adentro-costa afora.

É interessante acrescentar também que todas as desembocaduras fluviais do setor $\checkmark$ correspondem a zonas de sotamar de células de deriva litorânea grandes ou pequenas. Isso já havia sido notado por SOUZA (1996) no municipio de São Sebastião. No trecho entre Boracéia e Guaecá essas células definem transportes predominantes para E/SE. SOUZA (1996) atentou para o fato de que não somente as desembocaduras encontram-se deslocadas rumo ao Canal de São Sebastião, como também toda a bacia de drenagem à retaguarda de cada um desses rios. A autora atribuiu isso a um possivel basculamento estrutural do embasamento das planicies costeiras, com adernamento para o Canal de São Sebastião. Este canal representa uma estrutura deprimida com provável condicionamento tectônico apresentando fortes evidências morfológicas de falhamentos normais, como facetas triangulares de direções NNE e NNW associadas a espigões e vales transversais perpendiculares a estas direções, presentes nas rochas do embasamento do continente e da ilha. Além disso, a linha de costa ao longo do canal é definida por um recorte serrilhado com praias anormalmente retas embutidas entre pequenos $e$ isolados pontões de embasamento. Examinando fotografias aéreas do local observa-se que há um certo "encaixe" da linha de costa entre os dois lados do Canal de São Sebastião, principalmente ao norte. Todas essas evidências sugerem eventos de ruptura e distensão no desenvolvimento do canal e origem tectônica associada a uma estrutura do tipo gráben. Não obstante, os abatimentos tectônicos existentes no Planalto do Juqueriquerê (CAMPANHA et al., 1994), localizado a noroeste do canal, corresponderiam então a uma seqüência de blocos basculados associados ao gráben de São Sebastião. 
Por outro lado, o Canal de São Sebastião se abre, ao norte, em uma ampla enseada, onde ocorrem as menores declividades da plataforma continental da região (vide capítulo VII), e uma planície costeira (Caraguatatuba-Massaguaçu) de dimensões avantajadas para um litoral tão recortado, onde as drenagens continentais e suas desembocaduras estão todas voltadas para sul, também rumo ao canal. A circulação no interior deste canal é caracterizada por um fluxo intenso e predominante de rumo NE, que atravessa o canal no seu lado mais profundo, margeando a llha de São Sebastião e desembocando na Enseada de Caraguatatuba (FURTADO, 1978). Um fluxo fraco e intermitente, de sentido contrário, que margeia o continente em profundidades bastante rasas também ocorre, sendo alimentado pelas correntes longitudinais formadas no interior da Enseada, denominadas de "Sistema Sul de Caraguatatuba" (SOUZA, 1990). Portanto, a zona de sotamar do fluxo principal do canal é também a área de menor declividade da região.

Poderiam as correntes costeiras, pelo menos em parte, ser deslocadas em função do comportamento estrutural/geomorfológico de uma linha de costa? Se toda a drenagem de uma planície costeira pode ser condicionada pelo arcabouço estrutural, por que a "drenagem litorânea" também não o seria, pelo menos parcialmente? Será que toda a dinâmica de correntes existente entre o Canal e a Enseada é fruto puramente de fatores oceanográficos (ondas e marés)? Essas questões relacionadas à evolução geológica da área, especialmente durante o Quaternário, são dificeis de serem respondidas e exigiriam também trabalhos de geofisica marinha e continental.

\section{6. SETOR MORFODINÂMICO VI}

Este setor compreende o interior do Canal de São Sebastião e, por isso, apresenta caracteristicas próprias.

\section{6. 1. Análise de Produtos de Sensoriamento Remoto}

Foram analisadas fotografias aéreas de 1962, 1965/1966, 1987 e 1994 (quadro 3). 
A figura 52 mostra que nas praias ao longo do Canal de São Sebastião predominam dois sistemas principais de transporte, que estão relacionados ao comportamento das correntes de fundo aí atuantes, conforme foi comentado anteriormente.

No lado continental do canal as correntes são orientadas predominantemente para o sul. Nas praias da liha de São Sebastião, o transporte atua principalmente rumo ao norte. Algumas inversões locais ocorrem nas praias dos dois lados, associadas a reentrâncias da costa ou à presença de estruturas artificiais perpendiculares ou transversais à linha de costa.

No lado externo da liha de São Sebastião as correntes contornam a ilha, para norte ou oeste, a partir da Ponta do Boi (Morro do Mirante) no setor sudeste da ilha.

Os padrões acima descritos também são observados nas imagens de satélite de 1976 e da década de 90.

\section{6. 2. MÉTODO DE TAGGART \& SCHWARTZ-MODIFICADO}

Foram estudadas três praias localizadas no lado continental do Canal de São Sebastião: Balneário, São Francisco e Cigarras. Em cada uma apenas um perfil foi levantado, em sua porção central. A figura 53 mostra os resultados obtidos por este método para o setor VI.

As praias do Balneário e Cigarras estão localizadas nos extremos sul e norte do Canal, respectivamente. Entre elas, a mais aberta e, portanto, sujeita a maior energia de ondas é a Praia das Cigarras. São Francisco encontra-se na porção central do Canal, estando muito abrigada e recebendo apenas ondas difratadas e refletidas pela llha de São Sebastião, e ondas formadas por ventos locais.

As figuras 54 e 55 mostram as características morfológicas dessas praias. Nota-se que a Praia do Balneário é a mais larga e também a menos inclinada das três, apresentando perfil plano. Isso ocorre devido a sua posição mais aberta em relação às ondas mais enérgicas, que se propagam de SSW-S-SSE. A Praia das Cigarras apresenta perfil em degraus, com berma bem desenvolvida, sendo a inclinação da antepraia bem maior $\left(5-10^{\circ}\right)$ e a largura bem menor (com diferenças de mais de $20 \mathrm{~m}$ ) que na Praia do Balneário (inclinação de 1,5 a $3^{\circ}$ ). Isso ocorre porque ela se encontra atrás da liha de São Sebastião, abrigada da ação das ondas de SW a ESE, recebendo mais diretamente 
apenas as ondas de E e NE, estas últimas, em geral, produzidas por difração e reflexão de outros trens de ondas. A Praia de São Francisco tem características mais reflexivas das praias abrigadas em costa de maior declividade, sendo bastante estreita e inclinada.

A figura 56 exibe os gráficos de variação textural das três praias. Na Praia do Balneário predominam areias médias a finas, moderadamente a pobremente selecionadas. Em São Francisco as modas são amplas, misturando-se areias médias, grossas e finas e até fragmentos de rocha, moderadamente e pobremente selecionadas. Na Praia das Cigarras as areias são médias e moderadamente selecionadas.

A "matriz de comparação" (quadro 48) foi aplicada apenas para se poder visualizar possiveis interpretações sobre o transporte entre essas praias. Os resultados, embora ainda pouco conclusivos, sugerem transportes para norte e para sul, que estão de acordo com as medições de correntes feitas no canal por FURTADO (1978).

Quadro 48: Matriz de comparação elaborada para as praias de Balneário, São Francisco e Cigarras

\begin{tabular}{|c|c|c|c|c|c|c|c|c|c|}
\hline \multirow[b]{2}{*}{$\begin{array}{c}\text { Etapa } \\
\text { de } \\
\text { Amost }\end{array}$} & \multirow[b]{2}{*}{$\begin{array}{l}\text { Perfil } \\
\text { Praial }\end{array}$} & \multicolumn{3}{|c|}{ PARÁM. TEXTURAIS } & \multicolumn{2}{|c|}{ MORFOLOGIA } & \multirow[b]{2}{*}{$\begin{array}{c}\text { Resultado } \\
\text { Final }\end{array}$} & \multirow[b]{2}{*}{$\begin{array}{c}\text { PROCESSO } \\
\text { E=erosão } \\
D=\text { deposição } \\
T=\text { transporte }\end{array}$} & \multirow[b]{2}{*}{$\begin{array}{c}\text { SENTIDO } \\
\text { DA } \\
\text { DERIVA }\end{array}$} \\
\hline & & $\begin{array}{c}\text { Diâmetro } \\
\text { Médio }\end{array}$ & $\begin{array}{c}\text { Grau } \\
\text { de } \\
\text { Seleção }\end{array}$ & $\begin{array}{l}\text { Curto- } \\
\text { se }\end{array}$ & $\begin{array}{l}\text { Incli- } \\
\text { nação }\end{array}$ & $\begin{array}{l}\text { Largu- } \\
\text { ra }\end{array}$ & & & \\
\hline \multirow{3}{*}{ INV. } & 148 & - & - & - & + & 0 & - & $\mathrm{E}$ & $\mathrm{S}$ \\
\hline & 152 & $+1+$ & $+1+$ & $+1+$ & $-1-$ & $0 /-$ & $+/ t$ & $\bar{D}$ & $\mathrm{~S} / \mathrm{N}$ \\
\hline & 153 & - & - & - & + & + & $m$ & $\mathrm{E}$ & $\mathrm{N}$ \\
\hline \multirow{3}{*}{ VER. } & 467 & + & + & + & - & + & + & $\bar{D}$ & $\mathrm{~N}$ \\
\hline & 468 & $-1-$ & $-1-$ & $-1+$ & $+1-$ & $-1-$ & $-1-$ & $\bar{E}$ & $\mathrm{~N} / \mathrm{S}$ \\
\hline & 469 & + & + & - & + & + & + & D & $\mathrm{S}$ \\
\hline
\end{tabular}

As ortogonais de ondas medidas no campo (tabela 12) para algumas praias do continente e da liha de São Sebastião, indicam predominância de transportes para sul nas do continente, e para norte nas da ilha.

\section{6. 3. MÉTOdO DE MCLAREN}

Este método não pôde ser aplicado para o setor $\mathrm{VI}$ porque a quantidade de amostras comparadas seria bem inferior ao número minimo de 8 , proposto por MCLAREN \& BOWLES (1985), para se obter um resultado com algum significado estatístico. 


\section{6. 4. CONCLUSÕES}

Embora não se disponha de dados suficientes para obtenção de resultados plenamente confiáveis através do métodos de TAGGART \& SCHWARTZ-modificado e MCLAREN, as observações de campo, os dados de sensoriamento remoto e os dados de correntes conhecidos para o canal, sugerem a predominância de transportes gerais para sul ao longo da margem continental do Canal, para norte na margem oposta, e transportes que contornam a ilha, para norte e para oeste a partir da Ponta do Boi. Esses rumos, por outro lado, são coerentes com a propagação de ondas de SSW-S-SSE ou SE-ESE, incidindo ao redor da llha de São Sebastião.

Por outro lado, cabe salientar que toda esta linha de costa, continental e insular, tem sido fortemente modificada por interferências antrópicas associadas à ocupação e urbanização, ao Complexo Portuário e ao Terminal Petrolífero Almirante Barroso (TEBAR). Algumas pequenas praias que existiam ao sul do núcleo urbano desapareceram por completo quando uma extensa área já foi aterrada (reclaimed area) para uso do Complexo Portuário. Essas intervenções têm alterado o sistema de circulação local nas praias representado por pequenas células de deriva litorânea.

PONÇANO et al. (1994, in NAKAZAWA, et al.,1994) chegaram a conclusões semelhantes sobre os transportes sugeridos para o interior do Canal de São Sebastião (figura 3).

\section{7. SETOR MORFODINÂMICO VII}

Neste Setor foram estudadas as seguintes praias: Caraguatatuba, Martim de Sá, Massaguaçu, Mocoóca, Tabatinga, Maranduba, Sapê, Lagoinha, Fortaleza, Vermelha de Fortaleza, Dura, Lázaro, Enseada, Toninhas, Grande, Itaguá, Iperoig, Perequê-Açu, BarraSeca, Vermelha do Norte, Itamambuca, Félix, Prumirim, Puruba, Ubatumirim e Fazenda. $\mathrm{Em}$ algumas praias menores, que não possuem muita representatividade regional, apenas um perfil foi levantado, com a intenção de se obter informações de controle sobre as suas caracteristicas. 


\section{7. 1. Análise de Produtos de Sensoriamento Remoto}

Foram analisadas as fotografias aéreas dos sobrevôos de 1962, 1965 (parcial), 1979 (parcial), 1987 (parcial) e 1994 (parcial) (quadro 3).

O intenso recorte da linha de costa desse Setor, formando amplas enseadas e baías pequenas, promove o desenvolvimento de pequenas células de deriva litorânea (figura 57). Essas células resultam de muitas interferências que os trens de ondas sofrem ao se aproximar do litoral, tomando várias direções (tabela 13).

Assim, não é possivel observar uma tendência única de transporte ao longo deste setor. As ondas observadas nas fotografias sugerem, em geral, a presença de um trem principal, com cristas e direção bem definidas, e de um trem secundário, com incidência irregular. Muitas vezes, devido ao arqueamento das praias e à refração intensa das ondas, o mesmo trem apresenta várias direções em pontos próximos.

No interior da Enseada de Caraguatatuba (Caraguatatuba, Martim de Sá, Massaguaçu, Mocoóca e Tabatinga), predominam transportes gerais para sul, rumo do Canal de São Sebastião.

Nas Baías do Mar Virado (Maranduba, Sapê e Lagoinha), Fortaleza (Fortaleza, Vermelha de Fortaleza, Dura e Lázaro), Flamengo (Enseada), Ubatuba (Itaguá, Iperoig, Perequê-Açu e Barra-Seca), Ubatumirim (Ubatumirim) e Picinguaba (Fazenda), várias células menores, divergentes e convergentes parecem atuar.

Nas praias mais abertas, células divergentes também ocorrem e transportes para sul são freqüentemente observados ao longo dos costões rochosos mais externos.

Tendências de transporte semelhantes às encontradas nas fotografias aéreas foram vistas nas imagens de satélite de 1976 e da década de 90.

\section{7. 2. MÉTOdO DE TAGGART \& SCHWARTZ-MODIFICADO}

A figura 58 mostra os resultados obtidos com a aplicação desse método. As ortogonais de ondas medidas no campo encontram-se na tabela 14.

As figuras $59 a, 59 b, 60 a, 60 b, 60 c$ e $60 d$ exibem os gráficos de largura e inclinação das praias deste setor. 


\section{- Caraguatatuba, Martim de Sá, Massaguaçu, Mocoóca e Tabatinga}

Essas praias foram analisadas em conjunto porque, de acordo com SOUZA (1990), fazem parte de um mesmo contexto oceanográfico, estando submetidas aos mesmos processos reinantes no interior da Enseada de Caraguatatuba. As três primeiras praias deste conjunto foram estudadas por SOUZA (1990), que estabeleceu comparações entre elas.

As menores larguras praiais foram encontradas ao norte de Caraguatatuba (perfil 157/473) e na parte central de Tabatinga (perfil 165/507). Esses perfis estão em áreas sujeitas a fortes processos erosivos. Os perfis de maior declividade foram observados nas porções centrais de Caraguatatuba, Massaguaçu (foto 18) e Mocoóca. A maior inclinação da antepraia foi medida na Praia da Mocoóca $\left(10,5^{\circ}\right)$, que é também a praia mais reflexiva dessa Enseada. As menores inclinações dessa zona foram obtidas ao sul de Caraguatatuba (foto 20). Esta é a área mais protegida de todo esse litoral, abrigada atrás da ltha de São Sebastião, onde se desenvolve uma planície de maré arenosa (SOUZA \& FURTADO, 1987; SOUZA, 1995b). SOUZA (1990) mediu inclinações bastante altas na antepraia do trecho central da Praia de Caraguatatuba $\left(13^{\circ}\right)$ e do extremo sul de Massaguaçu, onde encontrou até $30^{\circ}$.

As areias dessas praias variam de muito finas até muito grossas, muito bem a pobremente selecionadas (figura 61). Variações de granulometria e do grau de seleção também foram observadas ao longo das praias entre as duas etapas de amostragem.

Na praia de Caraguatatuba, do inverno ao verão, observou-se uma diminuição do tamanho dos grãos e melhora do grau de seleção das areias. No inverno a distribuição foi de $50 \%$ de areias finas, $25 \%$ de areias médias, $16,7 \%$ de areias grossas e $8,3 \%$ de areias finas, com $41,7 \%$ de termos muito bem, $41,7 \%$ moderadamente, $8,3 \%$ bem e $8,3 \%$ pobremente selecionados. No verão as distribuiçōes foram de $41,7 \%$ de areias finas, $33,3 \%$ de areias muito finas e $25 \%$ de areias médias, com $41,7 \%$ muito bem, $41,7 \%$ moderadamente e $16,6 \%$ bem selecionadas. As areias mais grossas e moderadamente selecionadas estão no trecho centro-norte da praia (perfil 156/472), que é também o de maior energia de ondas. As areias mais finas e melhor selecionadas estão no extremo sul da praia. 
Na Praia de Martim de Sá também ocorreu afinamento das areias no verão, que eram grossas e moderadamente selecionadas no inverno, passaram a médias $(66,7 \%)$ e grossas $(33,3 \%)$, moderadamente selecionadas no verão.

Em Massaguaçu predominam areias grossas e médias (44,4\% cada), mas também ocorrem areias muito grossas $(11,2 \%)$. Não ocorreram mudanças no tamanho dos grãos, mas o grau de seleção decaiu relativamente no verão, de $66,7 \%$ de termos moderadamente selecionados e $33,3 \%$ de bem selecionados no inverno, a $88,9 \%$ de termos moderadamente selecionados e $11,1 \%$ de bem selecionados no verão. As areias mais grossas ocorrem no extremo sul da praia e as mais finas (areias médias) no extremo oposto. O melhor grau de seleção, no entanto, está na porção central da praia.

SOUZA (1990) encontrou resultados muito semelhantes aos acima descritos.

Na Praia de Mocoóca as areias são médias e moderadamente selecionadas, não tendo sido verificadas variações significativas entre o inverno e o verão.

Em Tabatinga verificou-se aumento do tamanho dos grãos e melhora do grau de seleção, pelo menos em relação ao perfil central (perfil 165/507), quando foram comparadas as amostras de inverno e de verão. No inverno, $1.00 \%$ das areias eram finas, $77,8 \%$ eram moderadamente selecionadas e $11,1 \%$ bem e pobremente selecionadas. No verão, obteve-se $66,7 \%$ de areias médias e $33,3 \%$ de areias finas, com $100 \%$ moderadamente selecionadas. Nessa praia as areias mais finas estão no extremo leste e as mais grossas no extremo oeste.

Aplicando a "matriz de comparação" (quadro 49-A), foi possível obter as células de deriva litorânea para cada praia e, também, determinar os prováveis sentidos de transporte entre elas.

Na praia de Caraguatatuba uma pequena célula de transporte para N, com barlamar ao sul da praia (perfil 154/470) foi reconhecida nas duas etapas de amostragem. Uma outra célula completa, com barlamar no trecho norte da praia, foi também identificada nas duas etapas, com migração desta zona entre os pontos 157/473 (inverno) e 156/472 (verão). Este tipo de migração é normal em praias com geometria de "cabo de guarda-chuva" como Caraguatatuba, incidindo maior energia de ondas no trecho mais aberto para o mar e menor nas extremidades. No campo, essas diferenças de energia são identificadas com certa facilidade. A zona de sotamar dessas duas células encontra-se no setor centro-sul da 
praia (perfil 155/471), entre as desembocaduras do Ribeirão da Lagoa e do Rio Juqueriquerê. Isso explica o grande contraste morfológico e textural da praia encontrado nessa área em relação à porção pouco mais ao norte. Nesta área, como foi observado por SOUZA (1990), a praia fica bem mais larga e a inclinação bastante suave; a energia de ondas decresce e também desenvolvem-se algumas barras arenosas submersas chamadas popularmente de "coroas". Estas barras de deriva litorânea interrompidas, visíveis em fotografias aéreas de detalhe, resultam da convergência local de células, associada à estocagem de sedimentos finos.

Quadro 49-A: Matriz de comparação elaborada para as praias de Caraguatatuba, Martim de Sá, Massaguaçu, Mocoóca e Tabatinga

\begin{tabular}{|c|c|c|c|c|c|c|c|c|c|}
\hline \multirow{2}{*}{$\begin{array}{l}\text { Etapa } \\
\text { de } \\
\text { Amost }\end{array}$} & \multirow[b]{2}{*}{$\begin{array}{l}\text { Perfil } \\
\text { Praial }\end{array}$} & \multicolumn{3}{|c|}{ PARÁM. TEXTURAIS } & \multicolumn{2}{|c|}{ MORFOLOGIA } & \multirow[b]{2}{*}{$\begin{array}{l}\text { Resultado } \\
\text { Final }\end{array}$} & \multirow[b]{2}{*}{$\begin{array}{c}\text { PROCESSO } \\
\text { E=erosão } \\
\text { D=deposição } \\
T=\text { transporte }\end{array}$} & \multirow[b]{2}{*}{$\begin{array}{c}\text { SENTIDO } \\
\text { DA } \\
\text { DERIVA }\end{array}$} \\
\hline & & $\begin{array}{l}\text { Diâmetro } \\
\text { Médio }\end{array}$ & $\begin{array}{c}\text { Grau } \\
\text { de } \\
\text { Seleção }\end{array}$ & $\begin{array}{l}\text { Curto- } \\
\text { se }\end{array}$ & $\begin{array}{l}\text { Incli- } \\
\text { nação }\end{array}$ & $\begin{array}{l}\text { Largu- } \\
\text { ra }\end{array}$ & & & \\
\hline \multirow{12}{*}{$\begin{array}{l}\mathrm{I} \\
\mathrm{N} \\
\mathrm{V} \\
\mathrm{E} \\
\mathrm{R} \\
\mathrm{N} \\
\mathrm{O}\end{array}$} & 154 & + & + & - & - & - & - & $\mathrm{E}$ & $\mathrm{N}$ \\
\hline & 155 & $-1+$ & $-1+$ & $+1+$ & $+/+$ & $+1+$ & $+1+$ & $\mathrm{D}$ & $\mathrm{N} / \mathrm{S}$ \\
\hline & 156 & $-1-$ & $-1-$ & $-1+$ & $-1+$ & $-1+$ & $-1+$ & $\mathrm{T}$ & $\mathrm{S}$ \\
\hline & 157 & $+/(+)$ & $+/(+)$ & $-/(-)$ & $-/(+)$ & $-/(-)$ & $-/(+)$ & $\mathrm{E} /(\mathrm{D})$ & $\mathrm{S} /(\mathrm{S})$ \\
\hline & 158 & $(-1+)$ & $(-1-)$ & $(+/-)$ & $(-1-)$ & $(+/-)$ & $(-1-)$ & $(\mathrm{E} / \mathrm{E})$ & (SW/NE) \\
\hline & 159 & $(-) /-$ & $(+) /-$ & $(+) / t$ & $(+) / t$ & $(+) /+$ & $(+) /+$ & (D)/D & $(\mathrm{NE}) / \mathrm{SW}$ \\
\hline & 161 & $+/ t$ & $t / t$ & $-1+$ & $-1-$ & $-1-$ & $-1+$ & $\mathrm{T}$ & SW \\
\hline & 162 & $-/(-)$ & $-/(-)$ & $-/(-)$ & $+/(+)$ & $t /(+)$ & $-/(-)$ & $\mathrm{E} /(\mathrm{E})$ & $\mathrm{SW} /(\mathrm{NE})$ \\
\hline & 163 & $(+t+)$ & $(+/-)$ & $(+/-)$ & $(-1-)$ & $(-1-)$ & $(+/-)$ & $(\mathrm{D} / \mathrm{E})$ & $(\mathrm{NE} / \mathrm{NE})$ \\
\hline & 164 & $(-) / t$ & $(+) / t$ & $(+) /-$ & $(+) /-$ & $(+) /+$ & $(+) / t$ & (D)/D & (NE)/SW \\
\hline & 165 & $-1-$ & $-1+$ & $+/ t$ & $+1 / m$ & $-1-$ & $-1-$ & $\mathrm{E}$ & $\mathrm{SW} / \mathrm{NE}$ \\
\hline & 167 & + & - & - & + & + & + & $\bar{D}$ & $\mathrm{NE}$ \\
\hline \multirow{10}{*}{$\begin{array}{l}\mathrm{V} \\
\mathrm{E} \\
\mathrm{R} \\
\tilde{\mathrm{A}} \\
\mathrm{O}\end{array}$} & 470 & + & + & - & - & - & - & $\mathrm{E}$ & $\mathrm{N}$ \\
\hline & 471 & $-1+$ & $-1+$ & $+/ t$ & $+/ t$ & $+1-$ & $+/+$ & $\mathrm{D}$ & $\mathrm{N} / \mathrm{S}$ \\
\hline & 472 & $-1-$ & $-1+$ & $-1-$ & $-1-$ & $t+t$ & $+1-$ & $E$ & $\mathrm{~S}$ \\
\hline & 473 & $+/(+)$ & $-/(-)$ & $+/(+)$ & $+/(-)$ & $-/(-)$ & $+/(-)$ & $\mathrm{D} /(\mathrm{E})$ & $\mathrm{N} /(\mathrm{N})$ \\
\hline & 512 & $(-1+)$ & $(+/+)$ & $(-1+)$ & $(+/+)$ & $(+/-)$ & $(+/+)$ & $(\mathrm{D} / \mathrm{D})$ & (NE/SW) \\
\hline & 511 & $(-1) /-$ & $(-) /-$ & $(-) /-$ & $(-) /+$ & $(+) / t$ & $(-) /-$ & (E)/E & $(\mathrm{SW}) / \mathrm{NE}$ \\
\hline & 510 & $+1-$ & $+1-$ & $+1-$ & $-1-$ & $-1-$ & $+1-$ & $T$ & $\mathrm{NE}$ \\
\hline & 509 & $+/(t)$ & $+/(+)$ & $+/(+)$ & $+/(+)$ & $t /(t)$ & $+/(+)$ & $\mathrm{D} /(\mathrm{D})$ & $\mathrm{NE} /(\mathrm{SW})$ \\
\hline & 508 & $(-/+)$ & $(-1+)$ & $(-/-)$ & $(-1-)$ & $(-/+)$ & $(-/+)$ & $(\mathrm{E} / \mathrm{D})$ & $(\mathrm{SW} / \mathrm{SW})$ \\
\hline & 507 & $(-)$ & $(-)$ & $(+)$ & $(+)$ & $(-)$ & $(-)$ & (E) & $(\mathrm{SW})$ \\
\hline
\end{tabular}

Os locais de divergência de zonas de barlamar encontram-se, estão, atualmente, em franco processo erosivo (SOUZA, 1995a, 1995b; SOUZA \& SUGUIO, 1996a, 1996b). 
No setor sul ocorre forte estreitamento da praia e destruição da vegetação do mangue que ocorre na retro-praia, associada ao Rio Juqueriquerê (vide capitulo VII). Ao norte, árvores do jardim que ficava à retaguarda da praia estão sendo destruídas (fotos 19a e 19b). As causas desses processos são discutidas adiante, no capítulo VII.

O sinal negativo encontrado para o grau de seleção na amostra 473 provavelmente estaria relacionado a contribuições fluviais próximas (rios Santo Antônio ao sul e Ipiranga ao norte).

As ortogonais de ondas medidas no campo (tabela 14) sugerem um centro de divergência no ponto 154 no inverno e transportes predominantes para o norte no verão.

Na Praia de Massaguaçu uma célula completa foi identificada em ambas etapas de amostragem. No inverno, a zona de barlamar estaria ao norte da praia e a de sotamar no extremo oposto, enquanto no verão o sentido se inverteu, com barlamar ao sul e sotamar ao norte. No entanto, em ambas etapas as condições de tempo eram boas. A barra de desembocadura do Rio Massaguaçu encontrava-se completamente fechada no inverno (foto 18), mas estava parcialmente aberta no verão. Pelas observações de campo e de fotografias aéreas de várias épocas sabe-se que esta barra permanece grande parte do tempo fechada, sugerindo a existência de correntes para o sul nesse trecho. Segundo SOUZA (1995a), os dois sentidos de transporte podem ocorrer, podendo haver ainda uma terceira situação, quando o centro de divergência situa-se na porção centro-sul da praia.

Uma "matriz de comparação" foi aplicada aos dados de SOUZA (1990), com amostragens bem mais detalhadas e efetuadas em maio de 1985 (quadro 49-B). A figura 62 mostra as localizações dessas amostragens, bem como as características morfológicas dos perfis e a figura 63 corresponde aos dados granulométricos dessas amostras. 0 quadro 49-B mostra um centro de divergência no setor norte da praia, com sotamares no extremo norte e nas proximidades do Rio Juqueriquerê. Outro centro de divergência encontrava-se localizado ao sul do Rio Juqueriquerê, com sotamares junto ao rio e entre este centro e o extremo sul da praia. Uma terceira célula, de pequena escala, estaria atuando com bariamar no extremo sul da praia (planicie de maré) e sotamar no ponto anterior. Esses resultados são muito semelhantes aos encontrados nesta pesquisa e mostram transportes gerais para sul, com pequenas células atuando em sentido contrário, conforme foi identificado por SOUZA (1990). Na Praia de Massaguaçu, os resultados encontrados foram semelhantes aos de verão. 
Na Praia de Tabatinga foram identificadas duas células divergentes a partir do centro da praia, com sotamares nas extremidades, durante o inverno. A porção central dessa praia é também o trecho de maior energia de ondas e onde os processos erosivos são muito fortes (SOUZA \& SUGUIO, 1996a, 1996b), como é discutido no capítulo VII. No verão, este ponto também comportou-se como zona de erosão.

Além disso, parece haver intercâmbio de sedimentos entre as praias de Caraguatatuba, Martim de Sá e Massaguaçu, e entre Massaguaçu, Mocoóca e Tabatinga, pela atuação de transportes para o sul e para o norte. SOUZA (1990) verificou a predominância de transporte para SW ao longo da Praia de Martim de Sá, o que também é sugerido pelas medidas de ondas no campo (tabela 14).

Quadro 49-B: Matriz de comparação elaborada para as praias de Caraguatatuba, Martim de Sá e Massaguaçu com dados extraídos de SOUZA (1990)

\begin{tabular}{|c|c|c|c|c|c|c|c|c|c|}
\hline \multirow{2}{*}{$\begin{array}{c}\text { Etapa } \\
\text { de } \\
\text { Amost }\end{array}$} & \multirow[b]{2}{*}{$\begin{array}{l}\text { Perfil } \\
\text { Praial }\end{array}$} & \multicolumn{3}{|c|}{ PARÁM. TEXTURAIS } & \multicolumn{2}{|c|}{ MORFOLOGIA } & \multirow[b]{2}{*}{$\begin{array}{l}\text { Resultado } \\
\text { Final }\end{array}$} & \multirow[b]{2}{*}{$\begin{array}{c}\text { PROCESSO } \\
\text { E=erosão } \\
\text { D=deposição } \\
T=\text { transporte }\end{array}$} & \multirow[b]{2}{*}{$\begin{array}{c}\text { SENTIDO } \\
\text { DA } \\
\text { DERIVA }\end{array}$} \\
\hline & & $\begin{array}{c}\text { Diâmetro } \\
\text { Médio }\end{array}$ & \begin{tabular}{|l} 
Grau \\
de \\
Seleção
\end{tabular} & $\begin{array}{c}\text { Curto- } \\
\text { se }\end{array}$ & $\begin{array}{l}\text { Incli- } \\
\text { nação }\end{array}$ & $\begin{array}{l}\text { Largu- } \\
\text { ra }\end{array}$ & & & \\
\hline \multirow{2}{*}{$\begin{array}{c}\mathrm{m} \\
\mathrm{a}\end{array}$} & $\mathrm{CA}$ & - & + & + & + & - & + & $\mathrm{D}$ & $\mathrm{N}$ \\
\hline & $\mathrm{CB}$ & $+/+$ & $-1-$ & $-1-$ & $-1+$ & $+/+$ & $-1+$ & $\mathrm{T}$ & $\mathrm{N}$ \\
\hline \multirow{3}{*}{$\begin{array}{l}\mathrm{i} \\
\mathrm{o}\end{array}$} & $\mathrm{CC}$ & $-1-$ & $+1-$ & $t / t$ & $-1-$ & $-1-$ & $-1-$ & $\mathrm{E}$ & $\mathrm{N} / \mathrm{S}$ \\
\hline & $\mathrm{CD}$ & $+/+$ & $+1+$ & $-1-$ & $+1-$ & $+1-$ & $+1-$ & $\mathrm{T}$ & $\mathrm{S}$ \\
\hline & $\mathrm{CE}$ & $-1-$ & $-1-$ & $+1-$ & $+1-$ & $+/-$ & $+1-$ & $\mathrm{T}$ & $\bar{S}$ \\
\hline \multirow{3}{*}{$\begin{array}{l}d \\
e\end{array}$} & $\mathrm{CF}$ & $+/+$ & $+1-$ & $+1 /-$ & $+/+$ & $+1-$ & $+1-$ & $T$ & $\mathrm{~S}$ \\
\hline & $\overline{C G}$ & $-1+$ & $+/+$ & $+/ t$ & $-1-$ & $+1-$ & $+1+$ & $\mathrm{D}$ & $\mathrm{S} / \mathrm{N}$ \\
\hline & $\mathrm{Cl}$ & $-1-$ & $-1-$ & $-1-$ & $+1-$ & $+1+$ & $-1-$ & $\mathrm{E}$ & $\mathrm{N} / \mathrm{S}$ \\
\hline \multirow{2}{*}{$\begin{array}{l}8 \\
5 \\
\end{array}$} & $\mathrm{CJ}$ & $+1+$ & $+/+$ & $+/+$ & $+/ 0$ & $-1+$ & $+/+$ & $\mathrm{D}$ & $\mathrm{S} / \mathrm{N}$ \\
\hline & $\mathrm{CK}$ & - & - & - & 0 & - & - & $\mathrm{E}$ & $\mathrm{N} / \mathrm{S}$ \\
\hline \multirow{3}{*}{$\begin{array}{c}\text { maio/8 } \\
5\end{array}$} & $\mathrm{MA}$ & + & - & - & + & + & + & $\mathrm{D}$ & $\mathrm{NE}$ \\
\hline & MB & $-1+$ & $+/+$ & $+/+$ & $-1-$ & $-1-$ & $-1+$ & $\mathrm{T}$ & $\mathrm{NE}$ \\
\hline & $\mathrm{MC}$ & - & - & - & + & + & - & $E$ & $\mathrm{NE}$ \\
\hline
\end{tabular}

As medições de ondas no campo foram executadas sob condições de tempo bom no inverno e de tempo instável a bom no verão. Os rumos obtidos, em geral, estão de acordo com os resultados descritos anteriormente. Em cerca de $66,7 \%$ dos casos os rumos de correntes eram dirigidos para o sul e em $33,3 \%$ casos o sentido era contrário. 


\section{- Maranduba Sapê e Lagoinha}

Estas três praias formam um segmento contínuo, onde a maior energia de ondas parece atuar na porção oeste da Praia de Lagoinha. A Praia do Sapê corresponde a uma grande feição em tômbolo formada na retaguarda da liha de Maranduba.

Nas duas etapas de amostragem observou-se um aumento da largura do extremo sul da Praia de Maranduba para a Praia do Sapê, e do extremo oeste da Praia de Lagoinha para leste. A inclinação e a largura das praias foram, em geral, menores no inverno, pela atuação de uma frente fria e marés de sizígia nesta época e, em contraposição, às condições de maré de quadratura e tempo bom do verão. No inverno, os perfis de maior declividade se encontravam no extremo sul de Maranduba e porção central da Praia de Lagoinha. No verão, eles estavam apenas no extremo sul da Praia de Maranduba. A maior inclinação da antepraia foi medida em Lagoinha, onde se obteve até $14^{\circ}$ (inverno), enquanto que a menor inclinação $\left(0^{\circ}\right)$ ocorreu na Praia do Sapê.

A granulometria dessas praias variou entre os perfis e de uma etapa para outra (figura 64). Em geral, houve aumento no tamanho dos grãos e relativa melhora no grau de seleção, do inverno para o verão. No inverno a distribuição era de $33,3 \%$ de areias médias e igualmente de areias finas, $26,7 \%$ de areias muito finas e $6,7 \%$ de areias grossas, com $40 \%$ de termos moderadamente selecionados, $26 \%$ muito bem, $20 \%$ pobremente e $13,3 \%$ bem selecionados. No verão era de $60 \%$ de areias finas, $26,7 \%$ de areias médias e $13,3 \%$ de areias grossas, com; $46,7 \%$ de termos moderadamente, $33,3 \%$ muito bem, $13,3 \%$ bem e $6,7 \%$ de pobremente selecionados. As areias mais finas ocorrem no extremo norte da Lagoinha e as mais grossas nas partes centrais dessas praias.

A "matriz de comparação" (quadro 50) mostrou, para ambas as etapas, as mesmas tendências: uma célula completa com barlamar no extremo sul da Praia de Maranduba e sotamar na Praia do Sapê e duas células divergentes a partir do centro da Praia de Lagoinha, com sotamares na Praia do Sapê e no extremo leste da Praia de Lagoinha. Esses resultados estão de acordo com as observações de campo, pois o extremo sul da Praia de Maranduba está sofrendo processos erosivos intensos, a Praia do Sapê é deposicional (tômbolo) e o extremo leste da Praia de Lagoinha é o de menor energia de ondas de todo esse segmento.

As ortogonais de ondas medidas no campo (tabela 14) refletem condições meteorológicas diversas, de frente fria no inverno e de calmaria no verão. As medições 
feitas no ponto 185/504 explicam a formação do tômbolo, mostrando convergência de correntes. A maioria dos resultados está de acordo com as células descritas anteriormente e também com os obtidos por análise de produtos de sensoriamento remoto. Durante 0 inverno e o verão as ondas incidiam de SE com altos ângulos.

Quadro 50: Matriz de comparação elaborada para as praias de Maranduba, Sapê e Lagoinha

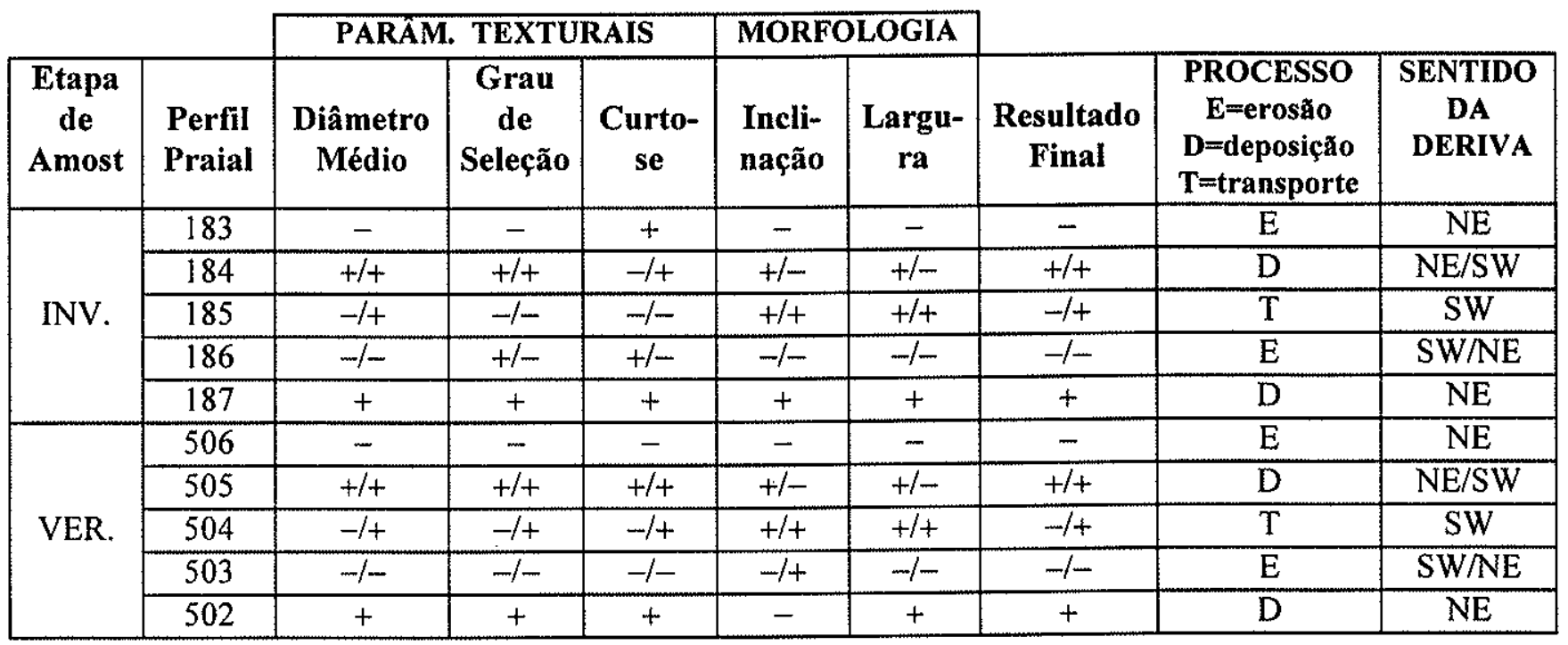

\section{- Fortaleza, Vermelha de Fortaleza, Dura e Lázaro}

Em cada uma dessas praias apenas um perfil foi levantado na suas porções centrais, visando a caracterização geral das praias no interior da Baía de Fortaleza.

No inverno as larguras foram muito menores e as inclinações maiores que no verão. Isso ocorreu devido às condições de frontogênese e de preamar de sizigia no inverno, em contraposição ao tempo bom e de maré de quadratura no verão. As praias de maior declividade e menor largura são as de Fortaleza e Vermelha de Fortaleza. Ambas têm características intermediárias a reflexivas, sendo as menos abrigadas por estarem voltadas para a boca SE da baia. A Praia Dura é a situada mais ao fundo da baía, mas também fica voltada para sua boca. Seu nome está relacionado a suas características de praia dissipativa de baixa energia e, portanto, com granulação mais fina de sedimentos de "maior coesão". A Praia do Lázaro é a mais abrigada, porém parte dela é voltada para o sul. A liha 
do Mar Virado, localizada ao sul mas fora da baía, também contribui para a atenuação das ondas associadas às frentes frias (SSW-S-SSE).

A variação dos parâmetros texturais dessas praias está representada na figura 65 .

Na Praia Vermelha de Fortaleza, predominam areias grossas e moderadamente selecionadas, mas no inverno foram também encontradas areias médias $(33,3 \%)$. Na Praia de Fortaleza predominaram areias médias $(66,7 \%)$ e moderadamente selecionadas no inverno, mas no verão, havia apenas areias finas, muito bem a pobremente selecionadas. A Praia Dura é constituída predominantemente de areias finas, muito bem a moderadamente selecionadas, mas no inverno ocorreram também areias muito finas. $\mathrm{Na}$ Praia do Lázaro as areias são finas $(66,7 \%)$ a muito finas $(33,3 \%)$, bem a pobremente selecionadas.

A "matriz de comparação" (quadro 51) foi aplicada nessas praias na tentativa de caracterizar possíveis intercâmbios de sedimentos no interior da Baía de Fortaleza. Os resultados foram interessantes pois mostraram, para ambas as etapas de amostragem, processos predominantemente deposicionais ao fundo da baia, com transporte rumo à Praia Dura. No inverno, sob condições de frente fria, notou-se a predominância de erosão na Praia de Fortaleza, como foi verificado no campo. No verão, a praia parecia mais estabilizada com perfil mais deposicional. Esses resultados estão de acordo com o transporte deduzido a partir da análise de produtos de sensoriamento remoto.

Quadro 51: Matriz de comparação elaborada para as praias de Fortaleza, Vermelha de Fortaleza, Dura e Lázaro

\begin{tabular}{|c|c|c|c|c|c|c|c|c|c|}
\hline & & & & & & & & \\
\hline & & \multicolumn{3}{|c|}{ PARÂM. TEXTURAIS } & \multicolumn{2}{|c|}{ MORFOLOGIA } & \multirow[b]{2}{*}{$\begin{array}{c}\text { Resultado } \\
\text { Final }\end{array}$} & \multirow[b]{2}{*}{$\begin{array}{c}\text { PROCESSO } \\
\mathrm{E}=\text { erosão } \\
\mathrm{D}=\text { deposição } \\
\mathrm{T}=\text { transporte }\end{array}$} & \multirow[b]{2}{*}{$\begin{array}{c}\text { SENTIDO } \\
\text { DA } \\
\text { DERIVA }\end{array}$} \\
\hline $\begin{array}{c}\text { Etapa } \\
\text { de } \\
\text { Amost }\end{array}$ & $\begin{array}{l}\text { Perfil } \\
\text { Praial }\end{array}$ & $\begin{array}{c}\text { Diâmetro } \\
\text { Médio }\end{array}$ & \begin{tabular}{|l} 
Grau \\
de \\
Seleção
\end{tabular} & $\begin{array}{c}\text { Curto- } \\
\text { se }\end{array}$ & $\begin{array}{l}\text { Incli- } \\
\text { nação }\end{array}$ & $\begin{array}{l}\text { Largu- } \\
\text { ra }\end{array}$ & & & \\
\hline \multirow{3}{*}{ INV. } & 188 & + & - & - & - & - & - & $\mathrm{E}$ & NW \\
\hline & 189 & $-1-$ & $+1-$ & $+1-$ & $+1-$ & $+1-$ & $+1-$ & $\mathrm{T}$ & NW \\
\hline & 190 & + & + & + & + & - & + & $\mathrm{D}$ & NW \\
\hline \multirow{4}{*}{ VER. } & 500 & + & + & + & + & + & + & $\overline{\mathrm{D}}$ & $\mathrm{SE}$ \\
\hline & 501 & $-1-$ & $-1-$ & $-1-$ & $-1-$ & $-1-$ & $-1-$ & $E$ & NW/SE \\
\hline & 499 & $t+1+$ & $+/ 4$ & $+1-$ & $+1+$ & $t / t$ & $+1+$ & $\mathrm{D}$ & NW \\
\hline & 498 & - & - & + & - & - & - & $E$ & WNW \\
\hline
\end{tabular}


As medições de ortogonais de ondas (tabela 14) mostraram boa correlação com os resultados descritos acima, com rumos de transporte apontando para o interior da baía.

\section{- Enseada. Toninhas e Praia Grande}

As praias de Toninhas e Grande constituem um segmento quase contínuo. A Praia da Enseada foi considerada em conjunto com as demais porque nela apenas um perfil de controle foi levantado. Ela está localizada ao fundo da Baía do Flamengo, aberta para sua boca ao sul. As outras duas são praias mais abertas e voltadas para SE, mas a llha Anchieta constitui um anteparo para as ondas de SSW-S-SSE.

As larguras das praias foram menores e as inclinações maiores no inverno que no verão. Na amostragem da Praia Grande, as condições no inverno eram de tempo instável (final de frente fria) e de maré de sizígia em fase de subida, enquanto que no verão as condições eram de tempo bom e de maré de quadratura. Essas diferenças de condições provocaram variações marcantes nas larguras, bem como nas outras características, entre as duas etapas de amostragem. Entre as praias de Toninhas e Grande ocorre aumento progressivo da largura rumo ao extremo norte da Praia Grande. As maiores inclinações foram encontradas no extremo norte da Praia das Toninhas.

$\mathrm{Na}$ Praia da Enseada predominaram areias finas $(66,7 \%)$ nas duas etapas, seguidas de médias $(33,3 \%)$ no inverno e muito finas $(33,3 \%)$ no verão (figura 66$)$. O grau de seleção também variou, predominando os termos moderadamente $(66,7 \%)$ e pobremente selecionados $(33,3 \%)$ no inverno, mas predominando os termos bem $(66,7 \%)$ a pobremente $(33,3 \%)$ selecionados no verão.

Nas praias das Toninhas e Grande, também ocorreram mudanças no comportamento textural dos sedimentos (figura 66). Na Praia das Toninhas havia $50 \%$ de areias finas e muito bem selecionadas e $50 \%$ de areias médias e moderadamente selecionadas no inverno, enquanto que no verão havia predominância de areias finas $(66,6 \%)$ e $16,7 \%$ de areias médias e $16,7 \%$ de areias grossas, com $33,3 \%$ de termos muito bem, 33,3\% bem e 33,3\% moderadamente selecionados. Na Praia Grande também houve ligeiro aumento do tamanho dos grãos e diminuição do grau de seleção no verão, pois as areias finas $(100 \%)$, muito bem $(66,7 \%)$ a bem selecionados $(33,3 \%)$ no inverno, passaram a areias finas $(66,7 \%)$ e médias $(33,4 \%)$, com termos muito bem $(33,3 \%)$, bem $(33,3 \%)$ e 
moderadamente selecionados $(33,3 \%)$ no verão. Em geral, ocorreu diminuição do tamanho dos grãos e aumento do grau de seleção do trecho centro-norte da Praia das Toninhas para o extremo oposto dessa praia e rumo à Praia Grande.

A "matriz de comparação" (quadro 52) aplicada às praias das Toninhas e Grande mostrou tendências iguais para as duas etapas, permitindo identificar duas células divergentes a partir do centro centro-norte de Toninhas (ponto 194/495), com sotamares no extremo sul dessa praia e no canto norte da Praia Grande. Essa zona de divergência constitui o trecho de maior energia de ondas de ambas as praias e onde são observados intensos processos erosivos. Os extremos sul das Toninhas e norte da Praia Grande são as áreas de menor energia. Se as duas praias fossem analisadas independentemente, 0 ponto 195/494, na porção centro-sul da Praia Grande, se comportaria como zona de origem da célula de deriva litorânea com sotamar no seu extremo norte.

Quadro 52: Matriz de comparação elaborada para as praias de Toninhas e Grande

\begin{tabular}{|c|c|c|c|c|c|c|c|c|c|}
\hline & \multicolumn{3}{|c|}{ PARÁM. TEXTURAIS } & \multicolumn{2}{|c|}{ MORFOLOGIA } & \multirow[b]{2}{*}{$\begin{array}{c}\text { Resultado } \\
\text { Final }\end{array}$} & \multirow[b]{2}{*}{$\begin{array}{c}\text { PROCESSO } \\
\text { E=erosão } \\
D=\text { deposição } \\
T=\text { transporte }\end{array}$} & \multirow[b]{2}{*}{$\begin{array}{c}\text { SENTIDO } \\
\text { DA } \\
\text { DERIVA }\end{array}$} \\
\hline $\begin{array}{c}\text { Etapa } \\
\text { de } \\
\text { Amost }\end{array}$ & $\begin{array}{l}\text { Perfil } \\
\text { Praial }\end{array}$ & $\begin{array}{c}\text { Diâmetro } \\
\text { Médio }\end{array}$ & $\begin{array}{c}\text { Grau } \\
\text { de } \\
\text { Seleção }\end{array}$ & $\begin{array}{c}\text { Curto- } \\
\text { se }\end{array}$ & $\begin{array}{l}\text { Incli- } \\
\text { nação }\end{array}$ & $\begin{array}{c}\text { Largu- } \\
\text { ra }\end{array}$ & & & \\
\hline \multirow{4}{*}{ INV. } & 193 & + & + & + & + & - & + & $\mathrm{D}$ & SSW \\
\hline & 194 & $-1-$ & $-1-$ & $-1-$ & $-1-$ & $+1-$ & $-1-$ & $\mathrm{E}$ & SSW/NNE \\
\hline & 195 & $+1-$ & $+1-$ & $+1-$ & $+1-$ & $+1+$ & $+/ m$ & $\mathrm{~T}$ & $\mathrm{NNE}$ \\
\hline & 196 & + & + & + & + & - & + & $\mathrm{D}$ & NNE \\
\hline \multirow{4}{*}{ VER. } & 496 & + & + & + & + & - & + & $\mathrm{D}$ & SSW \\
\hline & 495 & $-1-$ & $-1-$ & $-1-$ & $-1-$ & $+/ m$ & $-1-$ & $\mathrm{E}$ & $\mathrm{SSW} / \mathrm{NNE}$ \\
\hline & 494 & $+1-$ & $+1-$ & $+1+$ & $+1 m$ & $+1-$ & $+1-$ & $\mathrm{T}$ & NNE \\
\hline & 493 & + & + & - & + & + & + & $\mathrm{D}$ & NNE \\
\hline
\end{tabular}

As medidas de ortogonais de ondas feitas no campo (tabela 14) mostram predominância de transportes para NE na Praia das Toninhas e para SW e NE na Praia Grande durante o inverno, mas apenas transportes para NE nas duas praias durante 0 verão. As ondas de S-SSE, que são as mais efetivas nessas praias tendem a gerar transporte para NE ao longo da Praia Grande. As ondas de ESE são bem mais fracas e as responsáveis pelo transporte para SW e, provavelmente, não são capazes de imprimir modificações texturais significativas nos sedimentos. A menor energia de ondas na Praia Grande atua no extremo sul, enquanto que a maior age principalmente no setor central da 
mesma podendo, às vezes, atingir também o setor norte. Evidências de processos erosivos são observados na porção central desta praia.

A maioria dos resultados descrito acima está de acordo com os obtidos pela análise de produtos de sensoriamento remoto.

\section{- Itaguá, Iperoig, Perequê-Açu e Barra-Seca}

Essas praias foram consideradas em conjunto pois todas estão situadas no interior da Baía de Ubatuba e, portanto, devem estar sujeitas a condições oceanográficas semelhantes.

Todas são caracterizadas por pequenas larguras e altas declividades. As menores larguras e maiores declividades foram constatadas no inverno, devido às condições de frontogênese e maré de sizígia reinantes na época. As maiores larguras (36 e $66 \mathrm{~m}$ ) praiais $e$ as menores inclinações da antepraia $\left(0\right.$ e $1^{\circ}$ ) foram encontradas no extremo norte da Praia do Perequê-Açu, próximo ao Rio Indaiá. As menores larguras (6 e $8 \mathrm{~m}$ ) e as maiores inclinações da antepraia $\left(10\right.$ a $\left.12^{\circ}\right)$, por outro lado, ocorrem na Praia de Barra-Seca, onde intensos processos erosivos estão culminado com a destruição do mangue à retaguarda da praia, por avanço da mesma sobre ele (capítulo VII).

A energia das ondas é baixa em toda a área devido ao caráter reflexivo das praias.

Essas praias apresentam ampla distribuição granulométrica, desde areias muito grossas a muito finas e portanto, exibem variados graus de seleção, desde muito bem até pobremente selecionadas (figura 67). Além disso, mudanças significativas desses parâmetros foram observadas entre o inverno e o verão.

Nas praias de Itaguá e Iperoig foram obtidas as seguintes distribuições no inverno: $33,4 \%$ de areias muito finas, $22,2 \%$ de areias médias, $22,2 \%$ de areias muito grossas, $11,1 \%$ de areias grossas e $11,1 \%$ de areias finas, com $44,5 \%$ de termos moderadamente selecionados, $33,3 \%$ de pobremente selecionados, $11,1 \%$ de muito bem e $11,1 \%$ de bem selecionados. No verão, $44,5 \%$ eram de areias muito grossas, $33,3 \%$ de areias médias e $22,2 \%$ de areias finas, com $33,3 \%$ de termos bem, $33,3 \%$ de pobremente, $22,3 \%$ de moderadamente e $11,1 \%$ de muito bem selecionados. Portanto, do inverno para o verão, houve aumento da granulometria e do grau de seleção. As areias mais grossas e pior selecionadas encontram-se no extremo norte da Praia de Iperoig. 
Nas praias de Perequê-Açu e Barra-Seca foi verificado aumento do tamanho do grãos e diminuição do grau de seleção. As distribuições granulométricas durante o inverno foram: $77,8 \%$ de areias finas, $11,1 \%$ de areias muito finas e $11,1 \%$ de areias grossas, com $88,9 \%$ de termos bem e $11,1 \%$ de moderadamente selecionados. As distribuições granulométricas durante o verão foram: $66,7 \%$ de areias médias, $11,1 \%$ de areias muito finas, $11,1 \%$ de areias finas e $11,1 \%$ de areias grossas, com $33,3 \%$ de termos moderadamente, $33,3 \%$ de pobremente, $22,3 \%$ de bem e $11,1 \%$ de muito bem selecionados.

Aplicando a "matriz de comparação" (quadros 53-A e 53-B) para essas praias foram verificadas tendências semelhantes nas duas etapas, o que sugere que as mudanças texturais não foram suficientes para alterar essas tendências. Nas praias de ltaguá e Iperoig verificou-se a existência de uma célula completa, com barlamar no extremo norte de Iperoig (ponto 201/490) e sotamar ao sul da Praia de Itaguá. Essas zonas são, respectivamente, de maior e menor energia relativa de ondas, conforme foi verificado no campo. No trecho norte de lperoig ocorrem processos erosivos que já causaram a morte de árvores antigas da praia.

Nas praias de Perequê-Açu e Barra-Seca foram identificadas duas células que convergem no extremo norte da primeira (ponto 180/488). O sinal negativo obtido para o grau de seleção nessa zona de sotamar pode estar ao aporte fluvial do Rio Indaiá. Como foi dito anteriormente, a Praia de Barra-Seca encontra-se em processo de forte erosão, com barlamar de célula localizado nela. O outro barlamar é encontrado ao sul da Praia do Perequê-Açu, onde os processos erosivos são também conspícuos, porém de menor intensidade (vide capitulo VII). O Rio Indaiá tem sua desembocadura via-de-regra deslocada para leste.

Os rumos das correntes obtidos pelas medições das ortogonais de ondas no campo (tabela 14), estão de acordo com os resultados acima apresentados. A maioria desses resultados também coadunam com os obtidos pela análise de produtos de sensoriamento remoto. 
Quadro 53-A: Matriz de comparação elaborada para as praias de Itaguá e Iperoig

\begin{tabular}{|c|c|c|c|c|c|c|c|c|c|}
\hline & \multicolumn{3}{|c|}{ PARÁM. TEXTURAIS } & \multicolumn{2}{|c|}{ MORFOLOGIA } & \multirow[b]{2}{*}{$\begin{array}{c}\text { Resultado } \\
\text { Final }\end{array}$} & \multirow[b]{2}{*}{$\begin{array}{c}\text { PROCESSO } \\
\mathrm{E}=\text { =erosão } \\
\mathrm{D}=\text { deposição } \\
\mathrm{T}=\text { transporte }\end{array}$} & \multirow[b]{2}{*}{$\begin{array}{c}\text { SENTIDO } \\
\text { DA } \\
\text { DERIVA }\end{array}$} \\
\hline $\begin{array}{c}\text { Etapa } \\
\text { de } \\
\text { Amost }\end{array}$ & $\begin{array}{l}\text { Perfil } \\
\text { Praial }\end{array}$ & $\begin{array}{l}\text { Diâmetro } \\
\text { Médio }\end{array}$ & $\begin{array}{c}\text { Grau } \\
\text { de } \\
\text { Seleção }\end{array}$ & $\begin{array}{c}\text { Curto- } \\
\text { se }\end{array}$ & $\begin{array}{l}\text { Incli- } \\
\text { nação }\end{array}$ & $\begin{array}{c}\text { Largu- } \\
\text { ra }\end{array}$ & & & \\
\hline \multirow{3}{*}{ INV. } & 199 & + & + & + & $t$ & + & + & $\mathrm{D}$ & $\mathrm{SSE}$ \\
\hline & 200 & $-1+$ & $-1+$ & $-1+$ & $-1-$ & $-1+$ & $-1+$ & $\mathrm{T}$ & SSE \\
\hline & 201 & $-1-$ & $-1-$ & $-1-$ & $+1-$ & $-1-$ & $-1-$ & $\mathrm{E}$ & SSE \\
\hline \multirow{3}{*}{ VER. } & 492 & + & + & + & + & + & + & $\mathrm{D}$ & SSE \\
\hline & 491 & $-1+$ & $-1+$ & $-1+$ & $-1+$ & $-1+$ & $-1+$ & $\mathrm{T}$ & SSE \\
\hline & 490 & - & - & - & - & - & - & $\mathrm{E}$ & SSE \\
\hline
\end{tabular}

Quadro 53-B: Matriz de comparação elaborada para as praias de Perequê-Açu e Barra-Seca

\begin{tabular}{|c|c|c|c|c|c|c|c|c|c|}
\hline \multirow[b]{2}{*}{$\begin{array}{l}\text { Etapa } \\
\text { de } \\
\text { Amost }\end{array}$} & \multirow[b]{2}{*}{$\begin{array}{l}\text { Perfil } \\
\text { Praial }\end{array}$} & \multicolumn{3}{|c|}{ PARÁM. TEXTURAIS } & \multicolumn{2}{|c|}{ MORFOLOGIA } & \multirow[b]{2}{*}{$\begin{array}{l}\text { Resultado } \\
\text { Final }\end{array}$} & \multirow[b]{2}{*}{$\begin{array}{c}\text { PROCESSO } \\
\text { E=erosão } \\
\text { D=deposição } \\
T=\text { transporte }\end{array}$} & \multirow[b]{2}{*}{$\begin{array}{c}\text { SENTIDO } \\
\text { DA } \\
\text { DERIVA }\end{array}$} \\
\hline & & $\begin{array}{l}\text { Diâmetro } \\
\text { Médio }\end{array}$ & $\begin{array}{c}\text { Grau } \\
\text { de } \\
\text { Seleção }\end{array}$ & $\begin{array}{c}\text { Curto- } \\
\text { se }\end{array}$ & $\begin{array}{l}\text { Incli- } \\
\text { nação }\end{array}$ & $\begin{array}{c}\text { Largu- } \\
\text { ra }\end{array}$ & & & \\
\hline \multirow{3}{*}{ INV. } & 181 & - & - & - & - & - & - & $\mathrm{E}$ & $\mathrm{NE}$ \\
\hline & 180 & $+/ t$ & $t+t$ & $+/ t$ & $+/+$ & $+1+$ & $+/+$ & $\mathrm{D}$ & $\mathrm{NE} / \mathrm{ESE}$ \\
\hline & 179 & - & - & - & - & - & - & $\mathrm{E}$ & NW \\
\hline \multirow{3}{*}{ VER. } & 489 & + & + & - & - & - & - & $\mathrm{E}$ & $\mathrm{NE}$ \\
\hline & 488 & $-1-$ & $-1-$ & $+/ t$ & $+/ t$ & $+/+$ & $+/+$ & D & $\mathrm{NE} / \mathrm{ESE}$ \\
\hline & 487 & + & + & - & - & - & - & $E$ & NW \\
\hline
\end{tabular}

\section{- Vermelha do Norte}

Esta praia tem caracteristicas intermediárias a reflexivas. Na sua porção central ocorrem falésias em depósitos marinhos holocênicos, constituindo o único caso ao longo de todo o setor VII.

Nesta praia ocorre aumento gradativo da largura de SW para NE, porém a inclinação é maior na sua porção central.

Do inverno ao verão verificou-se ligeiro aumento do tamanho dos grãos e diminuição do grau de seleção (figura 68 ). No inverno havia $66,7 \%$ de areias médias e $33,3 \%$ de areias grossas com $55,6 \%$ bem selecionadas e $44,4 \%$ muito bem selecionadas. No verão, as areias grossas predominaram, com $77,8 \%$, seguidas das areias médias $(22,2 \%)$, e uma distribuição de $55,6 \%$ bem selecionadas, $33,3 \%$ muito bem selecionadas e $11,1 \%$ 
moderadamente selecionadas. No inverno as areias ficaram mais finas e melhor selecionadas no extremo NE e mais grossas e pior selecionadas no extremo SW, mas no verão foi verificada uma inversão dessa tendência.

A "matriz de comparação" (quadro 54) mostra comportamentos semelhantes para as duas etapas de amostragem, permitindo identificar duas células divergentes no centro da praia com sotamares nos seus extremos. O sinal negativo obtido para o grau de seleção nas amostras 178 e 484 podem estar relacionados ao aporte de sedimentos de outras fontes na praia.

Os rumos de correntes obtidos com as medidas de ortogonais de ondas no campo (tabela 14) revelaram sentidos opostos para o inverno e o verão, embora as condições meteorológicas fossem semelhantes e de tempo bom nas duas etapas. As ondas se propagavam de SE no inverno e ESE no verão.

Os resultados obtidos com a análise de produtos de sensoriamento remoto foram semelhantes ao descrito acima. Também no campo foram observados processos erosivos na porção central da Praia Vermelha (vide capítulo VII).

Quadro 54: Matriz de comparação elaborada para a Praia Vermelha do Norte

\begin{tabular}{|c|c|c|c|c|c|c|c|c|c|}
\hline & \multicolumn{3}{|c|}{ PARÁM. TEXTURAIS } & \multicolumn{2}{|c|}{ MORFOLOGIA } & \multirow[b]{2}{*}{$\begin{array}{c}\text { Resultado } \\
\text { Final }\end{array}$} & \multirow[b]{2}{*}{$\begin{array}{c}\text { PROCESSO } \\
\text { E=erosão } \\
\text { D=deposição } \\
T=\text { transporte }\end{array}$} & \multirow[b]{2}{*}{$\begin{array}{c}\text { SENTIDO } \\
\text { DA } \\
\text { DERIVA }\end{array}$} \\
\hline $\begin{array}{l}\text { Etapa } \\
\text { de } \\
\text { Amost }\end{array}$ & $\begin{array}{l}\text { Perfil } \\
\text { Praial }\end{array}$ & $\begin{array}{l}\text { Diâmetro } \\
\text { Médio }\end{array}$ & $\begin{array}{c}\text { Grau } \\
\text { de } \\
\text { Seleção }\end{array}$ & $\begin{array}{c}\text { Curto- } \\
\text { se }\end{array}$ & $\begin{array}{l}\text { Incli- } \\
\text { nação }\end{array}$ & $\begin{array}{l}\text { Largu- } \\
\text { ra }\end{array}$ & & & \\
\hline \multirow{3}{*}{ INV. } & 178 & + & - & + & + & $-m$ & + & $\mathrm{D}$ & SW \\
\hline & 177 & $-1-$ & $+1-$ & $-1+$ & $-1-$ & $+1-$ & $-1-$ & $E$ & SW/NE \\
\hline & 176 & + & + & - & + & + & + & $\mathrm{D}$ & $\mathrm{NE}$ \\
\hline \multirow{3}{*}{ VER. } & 486 & - & + & + & + & - & + & $\mathrm{D}$ & SW \\
\hline & 485 & $+1-$ & $-1+$ & $-1+$ & $-1-$ & $+1 / m$ & $-1-$ & $\mathrm{E}$ & SW/NE \\
\hline & 484 & + & - & - & + & + & + & D & $\mathrm{NE}$ \\
\hline
\end{tabular}

\section{- Itamambuca}

A Praia de Itamambuca exibe características reflexivas a intermediárias, variando para dissipativas no extremo norte. As larguras aumentam rumo aos extremos da praia a partir de sua porção central, onde a declividade é maior. Em geral ocorrem bermas inferiores altas nos setores sul e cento-norte da praia. 
A granulometria e o grau de seleção das areias variaram sensivelmente de uma etapa de amostragem para a outra, havendo aumento no tamanho e no grau de seleção das areias (figura 69$)$. No inverno predominavam areias médias $(88,9 \%)$, ocorrendo ainda $11,1 \%$ de areias finas, com $100 \%$ de termos moderadamente selecionados. No verão apareceram areias grossas $(33,3 \%)$, mas ainda predominavam areias médias $(55,6 \%)$, além das areias finas $(11,1 \%)$, com $77,8 \%$ de termos moderadamente selecionados e $22,2 \%$ bem selecionados.

A "matriz de comparação" (quadro 55) mostrou tendências diferentes no inverno e verão. No inverno havia duas células divergentes no centro da praia, com sotamares nos extremos. No verão atuava uma célula com barlamar no setor sul e sotamar ao norte. Como foi visto anteriormente as observações de campo confirmaram o que era esperado. Nas porções central e sul da praia verificou-se mudança na energia relativa, variando conforme o ângulo de incidência de ondas. Os sinais negativos obtidos para o grau de seleção nas amostras 175 e 173 podem ser atribuídos a aportes de rios que desembocam nas proximidades destes pontos.

Quadro 55: Matriz de comparação elaborada para a Praia de Itamambuca

\begin{tabular}{|c|c|c|c|c|c|c|c|c|c|}
\hline & \multicolumn{3}{|c|}{ PARAM. TEXTURAIS } & \multicolumn{2}{|c|}{ MORFOLOGIA } & \multirow[b]{2}{*}{$\begin{array}{c}\text { Resultado } \\
\text { Final }\end{array}$} & \multirow[b]{2}{*}{$\begin{array}{c}\text { PROCESSO } \\
\mathrm{E}=\text { erosão } \\
\mathrm{D}=\text { deposição } \\
\mathrm{T}=\text { transporte }\end{array}$} & \multirow[b]{2}{*}{$\begin{array}{c}\text { SENTIDO } \\
\text { DA } \\
\text { DERIVA }\end{array}$} \\
\hline $\begin{array}{c}\text { Etapa } \\
\text { de } \\
\text { Amost }\end{array}$ & $\begin{array}{l}\text { Perfil } \\
\text { Praial }\end{array}$ & $\begin{array}{c}\text { Diâmetro } \\
\text { Médio }\end{array}$ & $\begin{array}{c}\text { Grau } \\
\text { de } \\
\text { Seleção }\end{array}$ & $\begin{array}{l}\text { Curto- } \\
\text { se }\end{array}$ & $\begin{array}{l}\text { Incli- } \\
\text { nação }\end{array}$ & $\begin{array}{c}\text { Largu- } \\
\text { ra }\end{array}$ & & & \\
\hline \multirow{3}{*}{ INV. } & 175 & + & - & - & + & + & + & $\mathrm{D}$ & SW \\
\hline & 174 & $-1-$ & $+1+$ & $+1-$ & $-1-$ & $-1-m$ & $-1-$ & $\mathrm{E}$ & SW/NE \\
\hline & 173 & + & - & + & + & + & + & $\mathrm{D}$ & $\mathrm{NE}$ \\
\hline \multirow{3}{*}{ VER. } & 483 & -- & - & - & + & + & - & $\mathrm{E}$ & $\mathrm{NE}$ \\
\hline & 482 & $+1-$ & $+1-$ & $+1-$ & $-1-$ & $-1-$ & $+1-$ & $\mathrm{T}$ & $\mathrm{NE}$ \\
\hline & 481 & + & + & + & + & + & + & $\mathrm{D}$ & $\mathrm{NE}$ \\
\hline
\end{tabular}

Os dados da tabela 14 mostram correntes para SW nas duas etapas de amostragem, ambas executadas sob condições de tempo bom, com ondas de SE-ESE. Embora essas tendências sejam coerentes com a propagação das ondas, não coadunam com as características da praia no setor norte. Isto poderia estar relacionado à imprecisão na medição das ondas no campo, uma vez que em praias onde há apenas uma quebra (tipo frontal ou ascendente) é mais difícil determinar a orientação exata da ortogonal. 


\section{- Eélix e Prumirim}

Estas praias foram analisadas juntas porque estão próximas entre si e apenas dois perfis foram levantados em cada uma. Cada perfil amostrado é representativo de condições diferentes de energia.

Na Praia do Félix a largura e a inclinação aumentam de SW para NE, enquanto que na Praia do Prumirim a relação é inversa.

Diferenças texturais não foram observadas entre o inverno e o verão (figura 70). $\mathrm{Na}$ Praia do Prumirim predominam areias grossas $(66,7 \%)$ a médias $(33,3 \%)$, moderadamente $(75 \%)$ a bem (25\%) selecionadas. Os termos mais grossos encontram-se no setor oeste. Na Praia do Félix as areias são médias $(50 \%)$ a grossas $(25 \%)$ e finas $(25 \%)$, bem $(58,3 \%)$ a moderadamente $(41,7 \%)$ selecionadas. Os sedimentos mais grossos encontram-se no extremo norte.

A "matriz de comparação" (quadro 56) mostra tendências diferentes para o inverno e o verão. No inverno foram identificadas uma célula com barlamar no extremo norte da Praia do Félix e uma célula com barlamar no extremo leste da Praia do Prumirim. No verão também foi encontrada uma célula em cada praia, porém com barlamares nos extremos opostos. Portanto, no inverno parece predominar transporte para SW e no verão para NE. Intercâmbios entre essas praias foram identificados como sendo da Praia do Prumirim para a Praia do Félix, nas duas etapas de amostragem, caracterizando portanto correntes para SW, como foi visto também nos produtos do sensoriamento remoto. Os sinais negativos encontrados nos graus de seleção das amostras 172 (Félix) e 517 (Prumirim) são atribuíveis ao efeito das contribuições fluviais com desembocaduras próximas a esses pontos.

Os rumos obtidos pelas ortogonais de ondas medidas no campo (tabela 14), nas duas etapas sob condições de tempo bom, estão de acordo apenas em parte com os resultados apresentados acima. Nas duas etapas os rumos obtidos na Praia do Félix foram para SW e na Praia do Prumirim para NE. 
Quadro 56: Matriz de comparação elaborada para as praias do Félix e Prumirim

\begin{tabular}{|c|c|c|c|c|c|c|c|c|c|}
\hline & \multicolumn{3}{|c|}{ PARÁM. TEXTURAIS } & \multicolumn{2}{|c|}{ MORFOLOGIA } & \multirow[b]{2}{*}{$\begin{array}{c}\text { Resultado } \\
\text { Final }\end{array}$} & \multirow[b]{2}{*}{$\begin{array}{c}\text { PROCESSO } \\
\text { E=erosão } \\
\text { D=deposição } \\
\text { T=transporte }\end{array}$} & \multirow[b]{2}{*}{$\begin{array}{c}\text { SENTIDO } \\
\text { DA } \\
\text { DERIVA }\end{array}$} \\
\hline $\begin{array}{c}\text { Etapa } \\
\text { de } \\
\text { Amost }\end{array}$ & $\begin{array}{l}\text { Perfil } \\
\text { Praial }\end{array}$ & $\begin{array}{l}\text { Diâmetro } \\
\text { Médio }\end{array}$ & \begin{tabular}{|c|} 
Grau \\
de \\
Seleção
\end{tabular} & $\begin{array}{l}\text { Curto- } \\
\text { se }\end{array}$ & $\begin{array}{l}\text { Incli- } \\
\text { nação }\end{array}$ & $\begin{array}{l}\text { Largu- } \\
\text { ra }\end{array}$ & & & \\
\hline \multirow{4}{*}{ INV. } & 172 & + & - & + & + & - & + & $\mathrm{D}$ & SW \\
\hline & 171 & $-/(+)$ & $+/(+)$ & $-/(-)$ & $-/(+)$ & $+/(+)$ & $-/(+)$ & $\mathrm{E} /(\mathrm{D})$ & $\mathrm{SW} /(\mathrm{SW})$ \\
\hline & 170 & $(-) /-$ & $(-) /+$ & $(+) /+$ & $(-) /-$ & $(-) / t$ & $(-) /+$ & $(\mathrm{E}) / \mathrm{D}$ & $(\mathrm{SW}) / \mathrm{SW}$ \\
\hline & 169 & + & - & - & + & - & - & $\mathrm{E}$ & SW \\
\hline \multirow{4}{*}{ VER. } & 519 & + & - & + & $\overline{-}$ & - & - & $\mathrm{E}$ & $\overline{\mathrm{NE}}$ \\
\hline & 518 & $-/(+)$ & $+/(-)$ & $-/(-)$ & $+/(+)$ & $+/(+)$ & $+/(+)$ & $\mathrm{D} /(\mathrm{D})$ & $\mathrm{NE} /(\mathrm{NE})$ \\
\hline & 516 & $(-) /-$ & $(+) / t$ & $(+) /-$ & $(-) /-$ & $(-) / t$ & $(-) /-$ & $(\mathrm{E}) / \mathrm{E}$ & $(\mathrm{NE}) / \mathrm{NE}$ \\
\hline & 517 & + & - & + & + & - & + & $\mathrm{D}$ & $\mathrm{NE}$ \\
\hline
\end{tabular}

\section{- Puruba}

Esta praia exibe características predominantemente reflexivas a intermediárias (foto 17). Representa uma praia-barreira, que encerra atrás de si um canal flúvio-lagunar raso (Rio Puruba). A desembocadura é estreita e profunda, com forte dinâmica deposicional e erosiva na barra.

A largura da praia aumenta e a declividade diminui de SW para NE. As maiores inclinações da antepraia ocorrem no setor sul, onde foram medidos ângulos de até $12^{\circ}$.

As areias mais grossas ocorrem no extremo sul, com afinamento rumo ao centro ou ao extremo norte (figura 71 ). Predominam areias grossas $(72,2 \%)$, mas também ocorrem areias médias $(16,7 \%)$ ou muito grossas $(11,1 \%)$. Esta última fração só ocorre no verão. 0 grau de seleção variou do inverno para o verão: na primeira etapa $55,6 \%$ eram moderadamente selecionados e $33,3 \%$ bem selecionados e na segunda etapa $77,8 \%$ eram moderadamente selecionados e $22,2 \%$ bem selecionados.

Verificou-se tendências semelhantes de transporte para NE nas duas etapas pela "matriz de comparação" (quadro 57), sendo identificada uma célula completa com barlamar localizado no extremo sul e sotamar no extremo norte da praia. O sinal negativo obtido na amostra 210 pode ser atribuído ao aporte de sedimentos do Rio Puruba, que desemboca próximo a este ponto. 
Quadro 57: Matriz de comparação elaborada para a Praia do Puruba

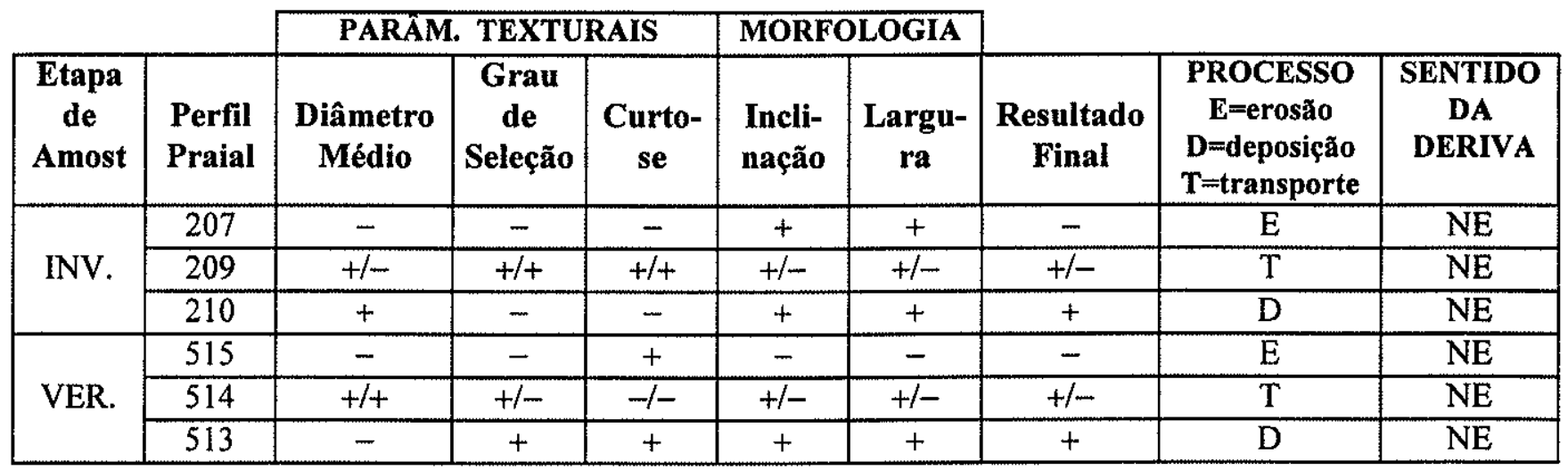

Esta é a única praia do litoral paulista, sem qualquer ilha frontal, onde foi possivel medir no campo dois trens de ondas (tabela 14) se interceptando na praia (porções central a norte). Muitas interferências ocorrem entre as ondas que se aproximam desta costa, que constitui a entrada da Baía de Ubatumirim. As várias ilhas presentes ao sul e a sudeste da praia e as próprias irregularidades dos costões rochosos delimitantes da baía causam essas interferências, gerando trens de ondas de vários rumos.

Conclui-se que, apesar da predominância de transporte resultante para NE, que também explica a manutenção da praia-barreira, a dinâmica de circulação não seja tão simples, podendo haver células locais.

\section{- Ubatumirim}

Esta praia encontra-se no interior da Baía de Ubatumirim, é orientada segundo NWSE e aberta para a boca dessa baía a SW. É segmentada pelo Rio Iriri, cuja desembocadura encontra-se geralmente deslocada para NW. Até meados da década de 70 havia um rio de porte médio (Rio Ubatumirim) desembocando no extremo SE da praia. Com a construção da BR-101 (1975-1976), o seu curso principal foi desviado para o Rio Iriri, originando uma extensa lagoa em seu curso inferior, e provocando o completo assoreamento da antiga desembocadura. Este local é mais abrigado e raso de toda a baia, com águas muito calmas e sem arrebentação, porém mais afetado por intensos processos erosivos, onde dezenas de metros de praia já sumiram destruindo parte da vegetação de restinga frontal (foto 21 e capitulo VII). 
A largura aumenta e a inclinação diminui rumo ao Rio Iriri, aproximadamente na porção central da praia. As maiores declividades ocorrem no trecho centro-norte, onde a energia de ondas é maior.

Variações texturais foram observadas do inverno para o verão, com aumento do tamanho e do grau de seleção dos sedimentos (figura 72). No inverno predominaram areias muito finas $(75 \%)$, seguidas das finas $(25 \%)$, com $63,9 \%$ de termos bem selecionados, $25 \%$ moderadamente e $11,1 \%$ muito bem selecionados. No verão as areias tornaram-se predominantemente finas $(91,7 \%)$, com apenas $8,3 \%$ de areias médias e o grau de seleção ficou com $50 \%$ de termos moderadamente, $25 \%$ muito bem e $25 \%$ bem selecionados. As areias mais finas ocorrem no extremo sul da praia e as mais grossas no extremo norte.

A "matriz de comparação" (quadro 58) mostrou tendências semelhantes para o inverno e verão, no segmento de praia na margem direita do Rio Iriri, obtendo-se uma célula com barlamar no extremo noroeste e sotamar próximo ao rio (ponto 211/479). Na praia da margem esquerda foi reconhecida uma célula com barlamar no extremo sul e sotamar no ponto $211 / 479$ durante o inverno. No verão, havia um centro de divergência no ponto 478 , com sotamares no ponto $211 / 479$ e no extremo sudeste da praia.

Os rumos das correntes obtidos pelas ondas medidas no campo (tabela 14) estão, quase sempre, de acordo com os resultados anteriores, os quais também corroboram os obtidos pela análise de produtos de sensoriamento remoto.

Quadro 58: Matriz de comparação elaborada para a Praia de Ubatumirim

\begin{tabular}{|c|c|c|c|c|c|c|c|c|c|}
\hline \multirow{2}{*}{$\begin{array}{c}\text { Etapa } \\
\text { de } \\
\text { Amost }\end{array}$} & \multirow[b]{2}{*}{$\begin{array}{l}\text { Perfil } \\
\text { Praial }\end{array}$} & \multicolumn{3}{|c|}{ PARÁM. TEXTURAIS } & \multicolumn{2}{|c|}{ MORFOLOGIA } & \multirow[b]{2}{*}{$\begin{array}{c}\text { Resultado } \\
\text { Final }\end{array}$} & \multirow[b]{2}{*}{$\begin{array}{c}\text { PROCESSO } \\
E=\text { erosão } \\
D=\text { deposição } \\
T=\text { transporte }\end{array}$} & \multirow[b]{2}{*}{$\begin{array}{c}\text { SENTIDO } \\
\text { DA } \\
\text { DERIVA }\end{array}$} \\
\hline & & $\begin{array}{l}\text { Diâmetro } \\
\text { Médio }\end{array}$ & $\begin{array}{c}\text { Grau } \\
\text { de } \\
\text { Seleção }\end{array}$ & $\begin{array}{c}\text { Curto- } \\
\text { se }\end{array}$ & $\begin{array}{l}\text { Incli- } \\
\text { nação }\end{array}$ & $\begin{array}{l}\text { Largu- } \\
\text { ra }\end{array}$ & & & \\
\hline \multirow{4}{*}{ INV. } & 212 & - & - & - & - & - & - & $\mathrm{E}$ & $\mathrm{SE}$ \\
\hline & 211 & $+1-$ & $+1-$ & $+/+$ & $+1+$ & $+/ t$ & $+1+$ & $\mathrm{D}$ & SE/NW \\
\hline & 206 & $+1+$ & $+1+$ & $-1-$ & $-1+$ & $-1+$ & $-1+$ & $T$ & $\mathrm{NW}$ \\
\hline & 205 & - & - & + & - & - & - & $\mathrm{E}$ & $\mathrm{NW}$ \\
\hline \multirow{4}{*}{ VER. } & 480 & - & + & - & - & - & - & $\mathrm{E}$ & SE \\
\hline & 479 & $+1+$ & $-1+$ & $+/+$ & $+1-$ & $+1-$ & $+1+$ & $\mathrm{D}$ & SE/NW \\
\hline & 478 & $-1-$ & $-1-$ & $-1-$ & $+1+$ & $+/+$ & $-1-$ & $\bar{E}$ & NW/SE \\
\hline & 477 & + & + & + & - & - & + & $\mathrm{D}$ & $\mathrm{SE}$ \\
\hline
\end{tabular}




\section{- Fazenda}

Esta praia tem orientação geral NW-SE e encontra-se no interior da Baía de Picinguaba, que é bem mais aberta que a de Ubatumirim.

As larguras da praia mostraram-se menores e as inclinações maiores no inverno que no verão, talvez porque as coletas foram realizadas em estágios diferentes de maré de sizígia, tendo sido preamar no inverno e baixamar no verão, além do tempo ter estado instável no primeiro e bom na outra etapa.

Variações texturais também ocorreram entre essas etapas de amostragem (figura 73), com aumento do tamanho e do grau de seleção dos sedimentos. No inverno foram encontradas $77,8 \%$ de areias muito finas e $22,2 \%$ de areias finas, com $66,7 \%$ de areais muito bem selecionadas, $22,2 \%$ bem e $11,1 \%$ moderadamente selecionadas. No verão havia apenas areias finas, muito bem $(88,9 \%)$ e bem selecionadas $(11,1 \%)$.

O quadro 59 mostra que no inverno havia uma célula completa com barlamar no extremo SE e sotamar do extremo oposto, mas no verão, havia um centro de divergência no centro da praia, com sotamares nos extremos.

Os rumos de correntes obtidos por ondas medidas no campo (tabela 14), executadas sob condições de tempo instável no inverno e bom no verão, sugerem transportes semelhantes aos descritos acima.

Quadro 59: Matriz de comparação elaborada para a Praia da Fazenda

\begin{tabular}{|c|c|c|c|c|c|c|c|c|c|}
\hline \multirow[b]{2}{*}{$\begin{array}{c}\text { Etapa } \\
\text { de } \\
\text { Amost }\end{array}$} & \multirow[b]{2}{*}{$\begin{array}{l}\text { Perfil } \\
\text { Praial }\end{array}$} & \multicolumn{3}{|c|}{ PARÂM. TEXTURAIS } & \multicolumn{2}{|c|}{ MORFOLOGIA } & \multirow[b]{2}{*}{$\begin{array}{c}\text { Resultado } \\
\text { Final }\end{array}$} & \multirow[b]{2}{*}{$\begin{array}{c}\text { PROCESSO } \\
\text { E=erosão } \\
\text { D=deposição } \\
T=\text { transporte }\end{array}$} & \multirow[b]{2}{*}{$\begin{array}{c}\text { SENTIDO } \\
\text { DA } \\
\text { DERIVA }\end{array}$} \\
\hline & & $\begin{array}{l}\text { Diâmetro } \\
\text { Médio }\end{array}$ & $\begin{array}{c}\text { Grau } \\
\text { de } \\
\text { Seleção }\end{array}$ & $\begin{array}{c}\text { Curto- } \\
\text { se }\end{array}$ & $\begin{array}{l}\text { Incli- } \\
\text { nação }\end{array}$ & $\begin{array}{l}\text { Largu- } \\
\text { ra }\end{array}$ & & & \\
\hline \multirow{3}{*}{ INV. } & 204 & - & - & + & + & + & + & $\mathrm{D}$ & $\mathrm{NW}$ \\
\hline & 203 & $+1-$ & $+/ t$ & $-1-$ & $-1+$ & $-1+$ & $-1+$ & $\mathrm{T}$ & NW \\
\hline & 202 & + & - & + & - & - & - & $E$ & NW \\
\hline \multirow{3}{*}{ VER. } & 476 & - & - & + & + & + & + & $\mathrm{D}$ & NW \\
\hline & 475 & $+1-$ & $+1-$ & $-1-$ & $-1-$ & $-1-$ & $-1-$ & $\mathrm{E}$ & NW/SE \\
\hline & 474 & + & + & + & + & + & + & $\mathrm{D}$ & $\mathrm{SE}$ \\
\hline
\end{tabular}




\section{7. 3. MÉTOdo DE MCLAREN}

Os quadros 60 e 61 (Volume II) mostram os resultados obtidos com a aplicação desse método, a partir dos quais se depreendem as tendências descritas a seguir.

(a) Os casos positivos totalizaram $33,7 \%$ das correlações possíveis no inverno e $30,9 \%$ no verão.

(b) Em ambas as etapas verificou-se a predominância de transporte para norte, ou seja, dirigido para a divisa do Estado com o Rio de Janeiro, totalizando $55,3 \%$ no inverno (Zestatístico $=26,858)$, e $61,7 \%$ no verão $(Z$ - estatístico $=27,164)$.

(c) O transporte no sentido oposto, rumo ao Canal de São Sebastião, embora menos freqüente, atingiu altas frequêencias, com $44,7 \%$ no inverno (Z- estatístico $=19,054$ ), e $38,3 \%$ no verão (Z- estatístico $=11,845)$.

(d) Em ambas as etapas predominaram os casos $B$, que corresponderam a $64,1 \%$ no inverno $(Z$ - estatístico $=32,220)$, e $70,3 \%$ no verão $(Z$ - estatístico $=32,790)$.

(e) Se os casos " $A$ " fossem computados, ainda haveria predominância de transportes para norte em ambas as etapas.

(f) As amostras 201/490 (norte de Iperoig) constituem área-fonte de quase todos os outros sedimentos mas apresentam raras fontes locais, sugerindo predomínio de erosão. Como foi dito anteriormente, isso realmente ocorre. Encontram-se em situação semelhante as amostras: 510 e 511 (Massaguaçu), $189 / 501$ (Fortaleza), 488/180 (Perequê-Açu), 179/487 (Barra-Seca), 483 (Itamambuca), 207/515 (Puruba) e 478 (Ubatumirim).

(g) A amostra 154/470 (sul de Caraguatatuba) dificilmente constitui área-fonte de outros sedimentos, mas apresenta muitas fontes locais. No entanto, os processos erosivos são bastante fortes. Isso sugere que as causas podem não ser naturais, mas antrópicas.

\section{7. 4. CONCLUSÕES}

Em geral, os três métodos mostraram resultados semelhantes, com transportes importantes rumo ao Canal de São Sebastião (sul) e à divisa do Estado (norte).

O quadro 62 mostra que as porcentagens obtidas são muito próximas, sendo estatisticamente iguais. 
Quadro 62. Comparação entre os resultados percentuais dos rumos de transporte obtidos a partir dos diferentes métodos utilizados.

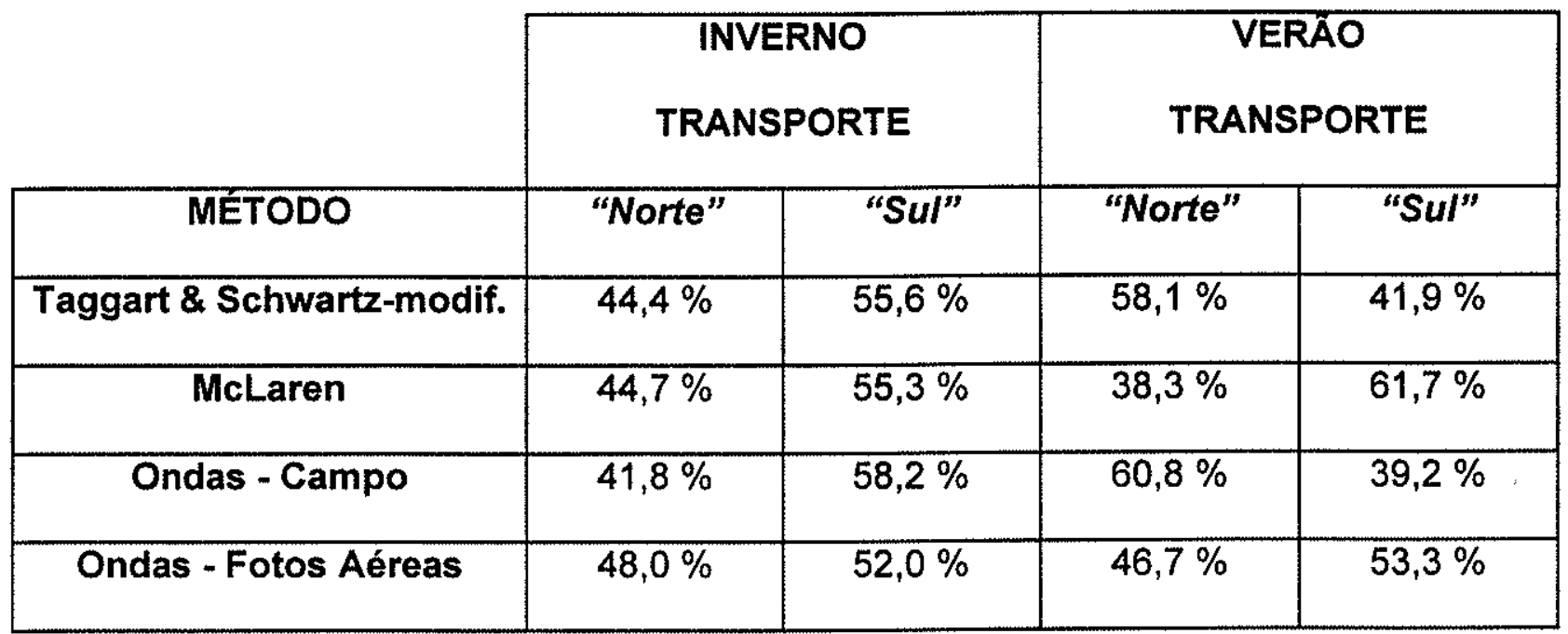

Os trabalhos de campo foram feitos sob diferentes condições meteorológicas. No inverno $22,4 \%$ em condições de frente fria, $34,5 \%$ com tempo instável (final de frente fria) e $43,1 \%$ com tempo bom. No verão, em $96 \%$ dos casos as condições de tempo eram boas e apenas $4 \%$ com tempo instável (final de frente fria). Comparando esses dados com os do quadro acima, para TAGGART \& SCHWARTZ-modificado e as ondas no campo, verificase que, sob condições de tempo predominantemente bom (verão), houve ligeira prevalência dos transportes para norte. Por outro lado, nas fotos aéreas, presumivelmente sob tempo bom, verificou-se sutil predominância dos transportes para sul. Pelo método de MCLAREN, o mais confiável para se obter os padrões de transportes regionais, verificou-se também predominância para o sul.

Portanto, no setor VII são igualmente importantes os transportes para sul e para norte fato que, de certa forma, poderia ser esperado pela morfologia fortemente recortada da linha de costa, exibindo enseadas, baías e inúmeras ilhas. Esta situação cria muitas interferências (refração, difração e reflexão) na incidência dos trens de ondas junto à costa e mudanças na sua direção de propagação, com o desenvolvimento de vários trens secundários. Com isso, várias células se formam no interior das praias.

FURTADO et al. (1987), fazendo uma síntese de trabalhos anteriores sobre a propagação de manchas de óleo a partir do canal de São Sebastião, após acidentes com navios, mostraram o transporte dessas manchas até a Baía de Ubatuba. Este fato 
evidencia que pelo menos os sedimentos colocados em suspensão são transportados rumo ao extremo norte.

O comportamento morfológico desta linha de costa imprime características diferenciadas às morfodinâmicas de suas praias. Em algumas delas coexistem estados reflexivo e dissipativo de baixa energia (exemplo: Itamambuca) ou estados intermediários e dissipativos de muito baixa energia como em Caraguatatuba (planície de maré). Estados reflexivos diferenciados também podem ser encontrados, ora associados a praias mais abertas de direção SW-NE (exemplo: Itamambuca e Puruba) ora a praias localizadas no interior de baías N-S (Itaguá, Iperoig, Barra-Seca).

No setor VII existem tipos diferentes de baias, cujas praias apresentam comportamentos morfodinâmicos distintos e, portanto, características morfológicas e sedimentológicas também distintas. Os tipos de baías são basicamente três: abertas para sul (Flamengo, Ubatumirim e Picinguaba); abertas para SE (Mar Virado e Fortaleza); abertas para leste (Ubatuba). As baías do Flamengo, Ubatuba e Picinguaba exibem fundo muito raso e plano. As praias possuem orientação NW-SE, pequena declividade e são formadas por areias finas a muito finas, em geral bem a muito bem selecionadas. Predomina o estado dissipativo de baixa energia. A Baía de Ubatuba, aberta para leste, apresenta praias com orientação N-S e WNW-ESE, declividades predominantemente altas e são formadas por areias muito grossas a muito finas, moderada a pobremente selecionadas. Predominam os estados reflexivo a intermediário. As baías abertas para SE têm características transicionais entre as anteriores, com praias de orientação SW-NE e SE-NW, sendo predominantemente do tipo intermediário. A Enseada de Caraguatatuba poderia ser incluida, parcialmente, entre o segundo e o terceiro tipos morfológicos.

Embora haja também um condicionamento geológico original, toda essa diferenciação pode ser vinculada à orientação da baía em relação à propagação das ondas: as ondas mais enérgicas provenientes de SSW-S-SSE, as ondas de energia intermediária que se propagam de SE e as mais tranqüilas de ESE-E-ENE. Assim, as baias abertas para o sul são frontalmente atingidas pelas ondas mais enérgicas e, por isso, são alongadas e planas, sendo constituídas de sedimentos finos e bem selecionados. As baias de orientação N-S recebem apenas as ondas mais fracas de leste, ou outras ondas já bastante enfraquecidas, não havendo energia suficiente para retrabalhar intensamente seus sedimentos, que permanecem grossos e mal selecionados. NORDSTROM (1977) 
referiu-se à ocorrência comum de sedimentos grossos e altas declividades em praias ao fundo de baías, atribuindo essas caracteristicas à baixa energia das ondas durante as calmarias (tempo bom), insuficiente para remover os sedimentos grossos carreados pelas tempestades. Finalmente, as baías SE estão sujeitas a amplo espectro de ondas, onde apenas parte das prajas recebe mais frontalmente as ondas de SSW a SSE, enquanto a outra porção fica mais abrigada. Por outro lado, as ondas de SE também são efetivas e, mesmo variando sua direção de poucos graus, podem gerar correntes de sentidos opostos.

Analisando-se o comportamento dessas baías pode-se concluir que os sistemas de propagação de ondas no litoral paulista variaram muito pouco, pelo menos durante todo o Holoceno.

As variações texturais encontradas em algumas praias no inverno e verão podem ser explicadas similarmente aos casos discutidos no setor IV (item VI. 5.4).

Finalmente, as praias mais abertas de direção SW-NE são as que apresentaram maior heterogeneidade em termos de circulação de células, com variações no inverno e no verão. Isso também pode ser associado a sua orientação em relação aos sistemas de ondas descritos anteriormente e ao fato de serem mais abertas sendo, portanto, mais suscetiveis às variações na propagação das ondas.

PONÇANO et al. (1994, in NAKAZAWA, et al.,1994) propuseram para este setor uma dinâmica predominantemente costa adentro e costa afora (figura 3). No entanto, este mecanismo parece ser incoerente para uma costa tão recortada como esta, onde as ondas sofrem interferências fortes, sendo gerados trens secundários, e onde as praias são em geral côncavas e encontram-se em estados morfodinâmicos variados. 


\section{A EROSÃo COSTEIRA NO ESTADO DE SÃo PAULO}

SOUZA \& SUGUIO (1995; 1996a, 1996b) têm enfatizado as questões relativas à erosão costeira no Estado de São Paulo. Os autores apresentaram mapas com as áreas onde foram encontrados processos erosivos ao longo de cada setor morfodinâmico. Esses mapas foram reproduzidos nas figuras $74,75,76,77,78,79,80 \mathrm{a}$ e $80 \mathrm{~b}$. Não se pretende aqui retomar as discussões feitas por aqueles autores, mas acrescentar novos dados ao problema, à luz dos resultados apresentados no capítulo anterior.

BRUUN \& SCHWARTZ (1985) apresentaram uma lista de sete fatores que podem promover a erosão costeira:

1. Efeitos dos impactos causados pela atividade humana, tais como, construção de estruturas artificiais, mineração de areias praiais, dragagens na plataforma continental e construção de barragens em rios;

2. Perdas de sedimentos para a plataforma, para a zona costeira e ao longo da praia e por atrito;

3. Redução no suprimento sedimentar devido à desaceleração de erosão das escarpas ou promontórios rochosos ou sedimentares litorâneos;

4. Redução do suprimento sedimentar da plataforma;

5. Aumento da freqüência e da intensidade das tempestades em áreas costeiras ou mudanças no ângulo de incidência das ondas;

6. Aumento da saturação de água na areia da praia devido à elevação de nível do lençol freático ou aumento de precipitação pluviométrica;

7. Elevação do nivel relativo do mar.

Estabelecer a influência de cada um desses fatores no balanço sedimentar de uma praia não é tarefa fácil, sendo necessários monitoramentos por vários anos sucessivos, e estudos de caráter regional. Como será visto adiante, para o caso do litoral paulista, parecem ser particularmente importantes ou mais facilmente identificáveis os impactos relacionados aos fatores 1,2 e 7 . Os fatores 3 e 4 não parecem estar ocorrendo, ou não são perceptiveis. Por outro lado, não existem estudos sobre esses assuntos. Em relação ao fator 5 , também não há trabalhos especificos sobre as variações nas freqüências de entrada de frentes frias e menos ainda sobre mudanças na incidência das ondas. $O$ fator 6 certamente está ocorrendo se associado, pelo menos, à elevação atual no nivel relativo do 
mar. Infelizmente, também não existem monitoramentos sobre água subterrânea no litoral paulista, uma vez que esse recurso é basicamente proveniente da Serra do Mar. A elevação média de nivel do mar para o litoral paulista tem sido estimada como sendo da ordem de 0,30 $\mathrm{m}$ para os últimos 50 anos (MESQUITA \& HARARI, 1988; MESQUITA, 1995), embora acredite-se que esta taxa seja discutivel, como apresentado no capitulo III (item III.1.4).

A grande maioria dos pesquisadores tem atribuído o processo atual e global de erosão costeira principalmente à elevação do nível relativo do mar (BIRD, 1986). BRUUN (1988) afirma que a única explicação possivel para o atual predomínio de erosão nas praias do mundo todo e o não ajuste das mesmas às condições de equilibrio (Regra de Bruun) é a contínua elevação de nível do mar. Não obstante, as particularidades de cada sistema costeiro têm papel fundamental nas respostas a este mecanismo. KOMAR (1995) ressalta a importância da suscetibilidade à erosão dos elementos que integram a costa (praia, dunas e falésias ou promontórios) e a dinâmica de circulação costeira (células de deriva litorânea e de corrente de retorno acentuando os processos erosivos).

$\mathrm{Na}$ costa brasileira as causas dos processos erosivos têm sido atribuídas a fatores naturais e/ou antrópicos. No Amapá, MENDES \& FARIA Jr. (1996) sugerem causas naturais para a forte destruição dos manguezais, como fatores climáticos e meteorológicos e fatores hidrodinâmicos, sendo inexistentes as intervenções antrópicas. Em Pernambuco, MANSO et al. (1996) atribuem a intensa erosão a intervenções antrópicas e à elevação atual de nível do mar. Para DOMINGUEZ (1995) a erosão na costa nordeste do Brasil não tem relação com a subida de nivel do mar, mas sim com o balanço sedimentar deficitário. No litoral do Rio de Janeiro as causas têm sido atribuídas a fenômenos naturais e a fatores antrópicos atuando simultaneamente (VALENTINI \& NEVES, 1989; COSTA, 1994, apud BASTOS \& SILVA, 1996; BASTOS \& SILVA, 1996). Na costa do Paraná, ANGULO (1993a) e ANGULO (1995) atribuem a erosão nas praias principaimente à ocupação inadequada da orla e às modificações na dinâmica costeira causadas por essa ocupação, embora hajam também causas naturais (ANGULO \& ANDRADE, 1982, apud ANGULO, 1993a; ANGULO 1993b). TOMAZELLI et all. (1996) sugerem que as causas da erosão nas praias do Rio Grande do Sul são essenciaimente controladas pela elevação atual de nivel relativo do mar, podendo ou não estar associada a um efetivo aumento na freqüência e/ou magnitude das tempestades extratropicais. 
BIRD (1987, apud MUEHE, 1994) apontou vários indícios que representariam respostas fisiográficas a uma elevação do nivel do mar, indícios esses que têm sido encontrados na costa paulista, como será visto adiante.

Ao longo do litoral de São Paulo foram encontrados onze tipos de evidências que caracterizam ou sugerem a atuação de processos erosivos. As tabelas 15 a 21 (Volume II) mostram, para cada setor morfodinâmico, o(s) tipo(s) de evidência(s) erosiva(s) encontrado(s) em cada perfil praial levantado.

Tipos de evidências erosivas encontradas no litoral paulista:

(0) Marés de sizigia noturnas (principalmente) atingindo freqüentemente a porção superior da praia, mesmo não estando associadas a marés de frentes frias. Em várias praias ou trechos de praias notou-se que as preamares noturnas de sizígia alcançam o limite superior da praia, muitas vezes não existindo a pós-praia.

(1) Retrogradação da linha de costa, com diminuição geral da largura da praia nas últimas décadas, ou mais acentuada em determinados locais, havendo ou não presença de embaiamentos. Comparando os vários conjuntos de fotografias aéreas utilizados nesta pesquisa (quadro 3), observou-se que ao longo das últimas três décadas a maioria das praias apresentou uma sensivel diminuição em sua largura. Embora a quantificação dessas variações seja acompanhada de erros, conforme comentado no capítulo IV (item IV.2.4), pode-se dizer que houve diminuições da ordem de várias dezenas de metros. Algumas praias apresentam embaíamentos pronunciados associados aos efeitos erosivos provocados pela presença de células de correntes de retorno concentradas, que imprimem uma forte redução na largura praial na zona de barlamar dessas correntes.

(2) Erosão remontante de depósitos marinhos e/ou eólicos holocênicos próximos à linha de costa. Em conseqüência da retrogradação da linha de costa, os depósitos marinhos frontais e as dunas sobrepostas a eles encontram-se em erosão. Esta é uma das principais evidências erosivas apontadas por BIRD (1987, apud MUEHE, 1994) como resposta fisiográfica a uma elevação de nivel do mar.

(3) Formação de falésias em terraços de cristas praiais holocênicas e/ou dunas e exposição de pacotes sedimentares, em geral de espessura métrica. A erosão acentuada dos depósitos marinhos e/ou dunas que limitam a praia leva ao desenvolvimento de falésias sobre os mesmos. Estas feições também são evidências 
de elevação atual de nivel do mar, segundo BIRD (1987, apud MUEHE, 1994). De acordo com PSUTY (1988), a formaçăo de escarpas em dunas sugere um balanço sedimentar negativo (déficit) na praia que interage com essas dunas.

(4) Erosão e destruição de estruturas artificiais construidas sobre os depósitos marinhos ou dunares holocênicos, a pós-praia, a antepraia ou a zona de surfe. Em várias partes do litoral de São Paulo observa-se a destruição de casas, muros, muretas, enrocamentos, anteparos etc., sejam eles instalados sobre a praia ou próximo a ela.

(5) Retomada erosiva de antigas plataformas de abrasão marinha, elevadas de $+2 a+6 \mathrm{~m}$, formadas sobre rochas do embasamento ígneo-metamórfico. Os costões rochosos que delimitam a maioria das praias paulistas apresentam até quatro niveis de plataformas de abrasão marinha, que se desenvolveram em condições de nivel marinho mais alto, durante o Pleistoceno e o Holoceno. Ocorrem níveis bem definidos elevados de 10, 6-5, 4 e $2 \mathrm{~m}$ acima do nível do mar atual. O mais alto encontra-se, em geral, provido de densa vegetação, com árvores altas. O segundo nivel mais elevado apresenta estágios de destruição da vegetação ou quase total ausência dela. Os níveis mais inferiores são normalmente atingidos pelas ondas associadas às preamares de sizígia, em especial durante o inverno, e de marés de tempestade. É comum observar marmitas e restos de antigas locas de ouriços preenchidas com areias praiais, até nas plataformas de $+6 \mathrm{~m}$.

(6) Destruição de faixas frontais de mangue ou de vegetação de restinga que margeiam a praia, devida à erosão e/ou ao soterramento causado pela retrogradação da linha de costa. Em vários locais onde a vegetação de restinga frontal ainda encontra-se preservada, não havendo ocupação urbana junto à praia ou estando ela recuada de vários metros, a retrogradação da linha de costa e/ou o avanço da praia rumo ao continente tem provocado também a destruição dessa vegetação, seja sobre os terraços marinhos, seja sobre as dunas. Em determinados locais a praia é margeada por faixas de mangue, as quais são também destruidas. Essas evidências foram também apontadas por BIRD (1987, apud MUEHE, 1994) como resposta a uma elevação de nível do mar.

(7) Exposição de pacotes ("falésias") formados de uma ou mais capas de aterros antigos destruidas ou soterradas por areias praiais. Estes pacotes, geralmente de espessura métrica, representam uma sucessão de eventos naturais, erosivos e deposicionais, associados a intervenções antrópicas. Normalmente, os pacotes são produto da colocação de aterro sobre areias do terraço marinho frontal e/ou de dunas, ou mesmo 
da pós-praia, o qual foi parcialmente destruído pelas ondas de preamares de sizígia ou de tempestade, e soterrado por areias praiais. As vezes, sobre essas areias foi colocada uma nova capa de aterro, posteriormente também erodida pelo mar.

(8) Exumação de antigos depósitos de turfa, laguna ou mangue e exposição sobre a antepraia e/ou a face litorânea atuais. Em algumas praias observa-se a exposiçăo de sedimentos associados a paleolagunas holocênicas, exumados após a forte erosão de depósitos marinhos holocênicos que recobriam ou interdigitavam esses sedimentos. Essa evidência é também foi considerada por BIRD (1987, apud MUEHE, 1994) como resposta à elevação de nivel do mar.

(9) Concentração de minerais pesados em determinados trechos da praia. Em algumas praias observou-se a concentração de minerais pesados em locais onde outras evidências erosivas também foram encontradas. Alguns autores têm verificado que há uma relação direta entre a concentração de minerais pesados e a predominância de processos erosivos na praia (FRIHY \& DEWIDAR, 1993).

(10) Presença permanente ou predominante de zona de barlamar ou de um centro de divergência de duas células de deriva litorânea em local(s) determinado(s) na praia, podendo estar associada também a correntes de retorno concentradas, causando erosão em praias com déficit sedimentar. Como foi visto no capítulo VI, na maioria das praias, as zonas associadas a barlamares de correntes de deriva litorânea ou de correntes de retorno apresentam características permanente e fortemente erosivas. Por outro lado, em algumas praias os processos erosivos são identificados também em zonas de sotamar de células costeiras. Essas características sugerem que balanço sedimentar dessas praias não se encontra em equilibrio, evidenciando-se um déficit sedimentar nas mesmas.

A seguir são apresentadas algumas discussões sobre as possiveis causas dos processos erosivos observados em cada setor morfodinâmico. 


\section{1. A EROSÃO COSTEIRA NOS SETORES MORFODINÂMICOS}

\section{1. 1. SETOR MORFODINÂMICO I}

Como pode ser observado na figura 74 e na tabela 15 ocorrem processos erosivos intensos ao redor de toda a llha Comprida. Nas extremidades NE e SW da ilha esses processos fazem parte da dinâmica sedimentar associada às correntes de maré na desembocadura lagunar de Cananéia, e aos fluxos lagunar e fluvial (Rio Ribeira de Iguape) na desembocadura lagunar de Icapara/Rio Ribeira de Iguape. Esses processos erosivos têm sido apontados desde o início de século (C.G.G., 1920). No entanto, o que chama a atenção na área da desembocadura lagunar de Cananéia é a presença de falésias em terraços marinhos e dunares de idade holocênica, com exposição de até $4 \mathrm{~m}$ dessas areias, com destruição da vegetação de restinga (foto 23 ). A dinâmica sedimentar no outro extremo da ilha na desembocadura de Icapara é diferente, pois estão sendo retrabalhados sedimentos marinhos recentes e dunas embrionárias (foto 24 ), sendo o processo erosivo bem menos perceptível, exceto através da comparação de produtos de sensoriamento remoto de várias épocas.

$\mathrm{Na}$ área de retro-barreira a erosão é observada ao longo de todo o Canal do Mar Pequeno ou de Fora (foto 25), sendo ativa também na llha de Cananéia. Nesta ilha os depósitos da Formação Cananéia, bastante endurecidos pela impregnação por compostos orgânicos (ácidos húmicos e/ou fúlvicos), sofrem desmonte e colapso segundo famílias de fraturas verticais de extensão (juntas neotectônicas) de direções N40-55E e N60-80W (foto 26), cujos blocos se amontoam na base dos terraços, ao nível da água. Isso é observado ao redor de toda a llha de Cananéia. Obviamente, os processos erosivos estão associados a porções mais côncavas dos canais. Em algumas áreas, como ao norte da llha Comprida em frente a lguape, predominam processos deposicionais e, juntamente com eles, ocorre o avanço da vegetação de mangue. Isso pode ser percebido pela comparação de fotografias aéreas e imagens de satélite de épocas diferentes. Segundo informações dos técnicos do Departamento Estadual de Proteção de Recursos Naturais (D.E.P.R.N.) da Secretaria do Meio Ambiente, este desenvolvimento lateral e vertical do mangue tem sido notado principalmente na última década.

$\mathrm{Na}$ parte frontal da liha Comprida ocorrem fortes processos erosivos em toda a porção centro-sul da praia, entre os pontos 5/432 e 11/418 (foto 2). O desenvolvimento de 
falésias em terraços holocênicos (depósitos marinhos e dunas) é intenso. Como foi visto no capitulo anterior, nesta área ocorre um centro de divergência de correntes de deriva litorânea, determinado através dos métodos de TAGGART \& SCHWARTZ-modificado e de sensoriamento remoto. Pelo método de MCLAREN as tendências predominantes neste trecho também foram erosivas, sendo esses sedimentos áreas-fonte da maioria dos outros depósitos do setor I, porém não possuindo fontes locais. Por outro lado, a ocupação é rara, havendo total preservação das dunas e terraços marinhos frontais. Durante o inverno, até nas preamares diurnas de sizígia, as marés invadem a pós-praia, praticamente isolando o norte e o sul da ilha. Os grandes embaiamentos presentes na praia estão associados a zonas de divergência e de convergência contíguas, com desenvolvimento de correntes de retorno concentradas. Segundo KOMAR (1995), essas feições constituem uma importante evidência de processo erosivo nas praias dos Estados Unidos.

A ocupação humana próxima à praia, na llha Comprida, é mais intensa somente ao norte. Entre os pontos 15/536-A e 536B também ocorrem fortes processos erosivos que já causaram a destruição de várias casas. Na etapa de campo de inverno, em 1992, restos de algumas delas ainda podiam ser vistos ocupando a antepraia inferior (foto 22). Entretanto, cerca de seis meses depois, em janeiro de 1993, eles já haviam sido totalmente destruídos e/ou soterrados. Mas a erosão continuou a avançar rumo à planície costeira, deixando novas casas sobre a praia e sujeitas à destruição (foto 27a). Em meados de 1996 foram construídos vários espigões de "bolsa-roca"1 para tentar conter a erosão local. No entanto, em dezembro de 1996 estas estruturas já se encontravam bastante danificadas (foto $27 \mathrm{~b}$ ). Segundo informações da empresa responsável pela obra, a areia contida nos sacos foi retirada do próprio local. Como foi visto no capítulo anterior essa área é muito problemática, pois é caracterizada pela ocorrência de um centro de divergência de pequenas células de deriva litorânea, e também pela influência da desembocadura lagunar de Icapara. Aparentemente, as poucas modificações antrópicas efetuadas na região não são suficientes para explicar os intensos processos erosivos observados ao longo da llha Comprida, sugerindo a maior importância das causas naturais.

Os processos erosivos observados na Praia do Leste resultam da intensa dinâmica imposta a essa praia pelas desembocaduras lagunar (lcapara) e fluvial (Rio Ribeira de Iguape) e pelas correntes de deriva litorânea provenientes de norte e de sul. Durante as

\footnotetext{
I"Bolsa-roca": grande saco de polietileno, fabricado em malha especial e preenchido com areia de mesma granulometria da praia, constituindo um espigão permeável e pouco rígido.
} 
preamares de sizígia, em especial no inverno, a praia fica parcialmente submersa e felizmente não há ocupação humana na praia.

Na Praia da Juréia ocorre erosão no setor sul, a qual está associada à dinâmica das desembocaduras do Rio Ribeira de Iguape e Icapara e, claramente, à ocupação antrópica. Os sérios danos causados às moradias levaram à construção de um muro de contenção. Esta estrutura pode causar interferências na circulação costeira local caracterizada, predominantemente, por constituir zona de sotamar de correntes provenientes de norte. No entanto, processos erosivos mais intensos ocorrem na porção norte da praia, causando forte escarpamento de depósitos holocênicos marinhos e dunares (foto 28). Neste local há um centro de divergência de células de deriva litorânea (segundo os métodos de TAGGART \& SCHWARTZ-modificado e de sensoriamento remoto) e os sedimentos são áreas-fonte para vários depósitos do setor 1 , porém não têm fontes locais (método de MCLAREN). Aparentemente, não há intervenção antrópica próxima que possa estar provocando ou acelerando esses processos. De acordo com os antigos moradores locais o Cemitério da Juréia, construído nesse local (ponto 25) há cerca de 40 anos a aproximadamente $60 \mathrm{~m}$ da praia, começou a ser destruido anos mais tarde por sucessivas ressacas, expondo covas e caixões. Ainda hoje há erosão no local.

\section{1. 2. SETOR MORFODINÂMICO II}

Neste setor, todo o trecho ao sul do Rio Una é praticamente intocado pelo homem.

Os processos erosivos observados nas praias do Rio Verde e Itacolomi e Una-Sul (figura 75 e tabela 16) resultam da dinâmica costeira, estando associados aos centros de divergência de células de deriva litorânea (método de TAGGART \& SCHWARTZmodificado e sensoriamento remoto) e, além disso, esses sedimentos constituem áreasfonte de vários outros depósitos praiais do setor II, mas apresentam fontes locais (método de McLAREN).

A Praia do Rio Verde parece estar em equilibrio, ora atravessando periodos mais erosivos, ora mais deposicionais. Nos anos de 1992 e 1993 houve predomínio de processos erosivos. Segundo BOMTEMPO (1991), no periodo de 1983 a 1985 também prevaleceram processos erosivos. Porém, em 1996, foram vistas feições sugestivas de processos deposicionais generatizados em quase toda a praia, com relativo alargamento 
da mesma e construção e isolamento de um cordão arenoso (foto 29) bem preservado em boa parte da praia, exceto no trecho central, onde já se encontrava erodido.

$\mathrm{Na}$ Praia de Itacolomi a dinâmica sedimentar parece ter sido análoga, com alargamento da mesma e abandono do terraço superior.

Na praia do Una-Sul, embora o extremo norte seja zona predominantemente de sotamar de células de deriva litorânea, processos erosivos são percebidos através da formação de falésias em depósitos marinhos e dunares holocênicos (foto 3 ), em parte devida à dinâmica da desembocadura do Rio Una. Entretanto, entre os pontos 547 e 62/521, e 551 e 64/522 também são encontradas falésias em terraços marinhos holocênicos. Nesses trechos foram encontrados centros de divergência de células de deriva litorânea pelos métodos de TAGGART \& SCHWARTZ-modificado e do sensoriamento remoto, sendo seus sedimentos áreas-fonte de vários outros depósitos praiais do setor 11 , mas tendo raras ou poucas fontes locais (método de MCLAREN). Ao longo dessa praia foi observado, em 1996, um cordão arenoso que não existia entre 1992 e 1993, sugerindo uma fase deposicional semelhante ao observado nas duas praias ao sul. Nos pontos destacados acima este cordão não foi encontrado, havendo erosão de depósitos holocênicos (foto 4). De acordo com BOMTEMPO (1991), no período de 1983 a 1985 prevaleceram processos erosivos em toda a Praia do Una.

No segmento Una-Norte, a erosão observada na praia resulta em parte da dinâmica costeira e fluvial, em parte da ocupação humana próxima à praia.

A Praia do Guaraú, como foi comentado no capítulo anterior, foi muito modificada por uma série de intervenções antrópicas que, em parte, aceleraram e, em parte, ocasionaram os processos erosivos observados nela e nas praias do Guarauzinho e Arpoador. O espigão do enrocamento feito na margem esquerda do Rio Guaraú, no extremo sul da praia, tinha originalmente cerca de $6 \mathrm{~m}$ de altura em relação ao fundo raso do canal (ALFREDINI, com. pessoal), mas hoje já se encontra parcialmente submerso (foto 30). O rio escavou um profundo canal lateralmente ao espigão e houve quase total preenchimento do prisma entre a antiga desembocadura, localizada na parte central da praia, e a atual. Esta intensa retenção de sedimentos (foto 30 ) que se mantinham anteriormente livres, associada às interferências que o espigão causa na incidência de ondas na praia, acelerou e/ou desencadeou forte processo erosivo observado na porção central da praia (foto 5). Isso levou à colocação de grandes blocos de rocha em frente às 
residências (foto 5), na tentativa de conter a erosão. Segundo moradores locais do condomínio e da própria prefeitura de Peruíbe da época, as casas não foram construidas sobre a praia, havendo uma avenida entre as casas e a praia. Entretanto, todo o loteamento foi feito sobre um enorme banco arenoso que constituía área de migração do rio sendo, portanto, área de risco. Os blocos rochosos usados para conter a erosão também modificam o ângulo de incidência das ondas, alterando o perfil praial. Atualmente, - processo erosivo está avançando sobre a porção norte da praia que além de ser relativamente mais abrigada, tem ocupação bem mais recuada que na parte central. As praias ao sul de Guaraú (Guarauzinho e Arpoador) também estão em erosão (foto 31 ).

\section{1. 3. SETOR MORFODINÂMICO III}

Nas praias de Peruíbe, Itanhaém e Praia Grande as áreas erosivas demarcadas na figura 76 são centros de divergência de células de deriva litorânea, segundo os métodos de TAGGART \& SCHWARTZ-modificado e de sensoriamento remoto, sendo esses sedimentos áreas-fonte de vários outros depósitos praiais do setor III, mas tendo raras ou poucas fontes locais, segundo o método de MCLAREN. A tabela 17 apresenta os principais indícios de processos erosivos encontrados nessas praias.

Apesar da evidente ação de causas naturais, a interferência antrópica tem papel muito importante nesses processos erosivos (fotos 6 e 7). A urbanização de maior parte desta orla, mais recentemente em Peruíbe, Itanhaém e parte norte de Praia Grande, é um problema sério promovendo a retirada de dunas e impermeabilização dos terraços holocênicos, para construção de casas (fotos 7 e 32a) e muretas (foto 32b), da avenida a beira-mar, de quiosques de praia (foto 6 ) etc.

Ainda hoje é possivel observar, em alguns locais principalmente em Peruibe e Itanhaém, restos de terraços marinhos holocênicos superpostos por pequenas dunas antigas e inativas sendo erodidos na praia (foto 6). Porém, a maior parte dessas praias encontra-se contornada por extensas muretas (foto $32 b$ ), usadas sob pretexto de embelezar a orla mas, na maioria das vezes, servindo como um anteparo de proteção à destruição de jardins, avenidas e residências pelas tempestades ou preamares de sizígia de inverno. 
Outro problema ainda mais grave é a retirada de areia da praia, seja para limpeza do lixo deixado pelos banhistas ou trazido pelas marés, para desassoreamento de canais de saneamento, ou para retirada do "excesso" de areia que se acumula junto às muretas das praias ou no passeio e/ou jardim públicos (foto $32 \mathrm{~b}$ ). O termo "excesso" é muito usado para justificar esse procedimento, mas é completamente indevido, pois essas areias não são excedentes na praia, mas fazem parte de seu balanço sedimentar (quadro 1), estando associadas ao retrabalhamento eólico e/ou à atuação de tempestades e ressacas. Na verdade, elas ficam ali acumuladas pois as construções artificiais acabam desempenhando o papel que deveria ser das dunas e dos depósitos marinhos holocênicos, de dissipadores de energia das tempestades e estocadores de sedimentos. A retirada dos sedimentos acumulados, junto às muretas, tem sido feita de maneira aleatória, de forma que sempre são mantidos livres $20-30 \mathrm{~cm}$ superiores das muretas.

Lamentavelmente, a extração de areia da praias, embora não autorizada pelo Departamento Nacional de Produção Mineral (D.N.P.M.) ou regulamentada pelo Ministério da Marinha (Capitania dos Portos), tem se tornado prática comum ao longo de todo o litoral paulista. Essas areias são usadas na pavimentação de ruas e até mesmo para o recobrimento de lixões. Na década de 80 iniciou-se a implantação de um novo sistema de pavimentação de ruas do litoral, considerado ideal pelas prefeituras locais devido ao seu baixo custo aparente. Ele consiste do assentamento de bloquetes sextavados sobre uma camada de areias finas (muito finas a médias), sem o uso de materiais fixadores (foto 33), requerendo assim manutenção periódica e reposição permanente de areias, que são facilmente lixiviadas pela água das chuvas e até mesmo pelo vento. Portanto, como a maior parte das praias paulistas é do tipo dissipativo ou intermediário-dissipativo, ou seja, é constituída de areias médias a muito finas, é fácil perceber porque esse sistema foi rapidamente difundido.

A limpeza pública das praias dissipativas e intermediárias-dissipativas, nas quais é possivel o trânsito de veículos pesados, é feita com tratores-escavadeiras que removem não somente o lixo, mas muita areia que é retirada da praia sobre caminhões (foto 34 ). 


\section{1. 4. SETOR MORFODINÂMICO IV}

A figura 77 mostra as áreas onde foram encontradas as evidências de processos erosivos listadas na tabela 18.

Neste setor, a maioria dos casos também pode ser associada à presença de zonas de barlamar ou centros de divergência de células de deriva litorânea, segundo os métodos de TAGGART \& SCHWARTZ-modificado e do sensoriamento remoto, sendo essas zonas áreas-fonte de sedimentos para várias outras praias do setor IV, mas tendo raras ou poucas fontes locais, segundo o método de McLAREN. Além disso, grande parte das interferências antrópicas são bastante antigas, sendo difícil afirmar se os processos erosivos são decorrentes delas ou de fatores naturais, ou mesmo se estas intervenções estão modificando os fatores naturais alterando, por exemplo, a circulação costeira com pequenas células de deriva litorânea sendo geradas ao redor de espigões ou de canais de saneamento.

Como foi comentado no capitulo anterior, nas praias do interior da Baía de Santos (São Vicente, Itararé e Santos) inúmeras intervenções antrópicas vem ocorrendo desde o final do século passado como, por exemplo: construção dos canais de saneamento (foto 8a); urbanização da orla, às vezes sem recuos adequados (foto $8 \mathrm{c}$ ) como no caso de São Vicente; fechamento do tômbolo da llha Porchat, isolando o transporte de sedimentos entre as duas baias; construção do grande espigão do emissário de Santos-São Vicente entre as praias de Santos e Itararé (fotos $8 \mathrm{a}$ e $8 \mathrm{~b}$ ); dragagem intensa do Canal do Porto, tanto na área da baía quanto dentro do estuário, desde o início do século; despejo deste material primeiramente (até meados da década de 70) nas proximidades da Ponta do Itaipu, depois entre a Ponta do Munduba e a llha da Moela; desassoreamento dos canais do Estuário Santista; intensa e pesada urbanização da llha de São Vicente (municípios de Santos e São Vicente), sobrecarregando pacotes espessos de areias intercaladas com camadas de argila orgânica e mole; aterro e ocupação de mangues; e extração de grandes volumes de areia das praias.

É interessante notar que, mesmo sob o efeito de todas essas modificações, as praias de Santos e Itararé apresentam poucas evidências erosivas, parecendo estar em equilíbrio relativo. As caracteristicas fisiográficas da área, como a orientação da praia aberta para sul, o estado dissipativo de baixa energia, a declividade muito baixa da plataforma continental, a presença de um estuário misto com extensos canais de maré, o 
amplo desenvolvimento de manguezais, fazem com que ela funcione como armadilha de sedimentos, continentais e marinhos. Por outro lado, quando os materiais dragados no porto eram despejados na Ponta de Itaipu, até o fim da década de 70, parte do mesmo retornava à Baía de Santos provocando várias modificações na batimetria local (SONDOTÉCNICA, 1977). Parte desse material retido no fundo da baía pode estar, até hoje, servindo para alimentar essas praias. Além disso, após o fechamento do tômbolo da Ilha Porchat e, mais ainda, após a construção do espigão do emissário de Santos-São Vicente, a transferência de sedimentos da Praia de Santos para as praias vizinhas (Itararé e São Vicente) passou a ser menor, aumentando a possibilidade de maior retenção desses sedimentos ao largo da Baía de Santos e do retorno dos mesmos à praia. A Praia de Itararé, que se mantinha em equilibrio pelo menos até antes da urbanização, também é uma importante fonte local de areias. Um último fator que pode ainda ser aventado é a relação entre os movimentos tectônicos e os eustáticos neste setor. Podem estar havendo efeitos compensatórios positivos entre a interação de forças tectônicas (soerguimento contínuo da Serra do Mar e movimentações relativas de blocos tectônicos) e eustáticas (elevação relativa de nível do mar atual), de forma que essas praias não sofram os efeitos causados por tantas intervenções antrópicas. Não obstante, um abaixamento de nível de base regional devido a fatores naturais ou induzidos por atividades antrópicas, como a retirada excessiva de sedimentos das praias, do leito dos canais e da plataforma, causaria intensificação dos processos erosivos nas bacias fluviais, propiciando a entrada de sedimentos ao sistema. Isto poderia explicar também porque os depósitos marinhos holocênicos não formam falésias nesta linha de costa e porque a taxa de elevação do nível relativo do mar parece ser menor do que em Cananéia e Ubatuba. Comparando a tabela 18 com as demais (tabelas 15 a 17 e 19 a 21b) percebe-se que o setor IV exibe a menor freqüência de evidências erosivas, estando a maior parte delas associada a atividades antrópicas.

As conclusões acima estão de acordo com exposto por HEALY (1996) sobre os impactos da atual elevação de nível do mar em regiões estuarinas. Segundo este autor, como os estuários são armadilhas de sedimentos, então, mesmo com o nível do mar se elevando, eles continuariam a ser preenchidos a uma taxa mais rápida que a da elevação do nivel do mar, causando uma diminuição no prisma de maré. Com isso, o fator tectônico poderia ser mais importante que o eustático. 
As atividades de limpeza pública e remoção de areias das praias são práticas comuns em outras praias desse setor, como Astúrias e Pitangueiras (foto 24 mostrada no setor III) e Enseada.

No setor IV são encontradas, em várias praias, antigas plataformas de abrasão marinha elaboradas sobre o embasamento, quando o nível do mar encontrava-se mais elevado que o atual. Elas ocorrem em níveis bem marcados no relevo dos costões rochosos que delimitam as praias. Atualmente, os níveis de $2 \mathrm{~m}, 4-5 \mathrm{~m}$ e $6 \mathrm{~m}$ estão sendo atingidos durante as preamares de sizígia, sem estarem associadas a tempestades. $O$ nível de $6 \mathrm{~m}$ tem se mantido desprovido de vegetação. Essas plataformas podem ser vistas em todo o litoral paulista, ganhando maior expressão a partir deste setor rumo ao norte (vide exemplo fotografado no setor VII).

\section{1. 5. SETOR MORFODINÂMICO V}

Neste setor, como nos dois anteriores, os processos erosivos parecem resultar da combinação de fatores naturais e intervenções antrópicas (figura 78 e tabela 19). No entanto, as intervenções são relativamente mais recentes e menos agressivas que nos setores III e IV. Em algumas praias como de Bertioga, de Itaguaré, de Guaratuba, de Boracéia, de Baleia e de Barequeçaba, mesmo em áreas onde não houve a destruição de dunas e depósitos marinhos frontais, estando a urbanização não implantada junto à praia ou recuada, são encontradas evidências de processos erosivos, como a formação de falésias nesses depósitos (foto 35 ), preamares de sizígia normalmente atingindo o limite superior da pós-praia (fotos 11 e 14) e o ataque das marés sobre antigas plataformas de abrasão marinha, além da geração desta feição em terraços marinhos holocênicos (foto 35). Na Praia de Maresias, por outro lado, observam-se fortes embaíamentos causados por barlamares de células de deriva litorânea associadas a corrente de retorno (foto 12), que causam erosão em trechos de praia com ocupação antrópica (foto 36 ).

\section{1.6. SETOR MORFODINÂMICO VI}

Ao longo do Canal de São Sebastião os processos erosivos são encontrados nas praias dos lados continental e insular (figura 79 e tabela 20). As planícies costeiras e as praias são estreitas por natureza e vem sofrendo muitas interferências devido à 
urbanização e às atividades do porto e do terminal petrolifero (TEBAR). Uma vasta área foi aterrada (reclaimed area) junto ao porto, causando o desaparecimento de pequenas praias. A Rodovia BR-101 margeia toda a parte norte do canal e grandes blocos rochosos são usados para proteger a base do muro da estrada (foto 37 ). Várias casas construídas às margens das praias, que eram muito mais largas, estão ameaçadas pelas marés (foto 15), que também estão derrubando árvores antigas (foto 16).

\section{1. 7. SETOR MORFODINÂMICO VII}

As figuras $80 \mathrm{a}$ e $80 \mathrm{~b}$ mostram a localização das evidências de erosão costeira listadas nas tabelas $21 \mathrm{a}$ e $21 \mathrm{~b}$.

Neste setor a maioria dos processos erosivos parece estar ligada a processos naturais, tais como, a presença de zonas de barlamar ou zonas de divergência de células de deriva litorânea identificadas pelos métodos de TAGGART \& SCHWARTZ-modificado e de sensoriamento remoto ou, ainda, por seus sedimentos serem áreas-fonte para outros depósitos do setor VII, como ocorre nas praias de Caraguatatuba (foto 38), Martim de Sá, Massaguaçu, Mocoóca, Tabatinga (foto 39), Maranduba, Enseada, Vermelha de Fortaleza, Dura, Lagoinha, Toninhas, Grande, Iperoig, Barra-Seca (foto 40a e 40b), Vermelha do Norte (foto 13), Puruba, Prumirim, Félix, Itamambuca, Ubatumirim, Brava e Fazenda. Porém, em vários locais é possivel também associá-los a intervenções antrópicas na orla, como em Caraguatatuba (fotos 19a e 19b), Martim de Sá, Maranduba, Sapê, Fortaleza, Dura, Enseada, Toninhas, Grande, Tenório, Lázaro, Itaguá, Perequê-Açu e Ubatumirim (foto 21 ).

Além das evidências encontradas nos outros setores, dois outros tipos foram especialmente observados neste setor, representados pela destruição e soterramento da vegetação de mangue e/ou restinga da retro-praia, por avanço do prisma praial sobre ela (Caraguatatuba, Mocoóca, Barra-Seca, Puruba, Ubatumirim e Fazenda) e pela exumação de depósitos lagunares holocênicos na antepraia (Tabatinga - foto 39). BIRD (1987, apud MUEHE, 1994) essas feições como respostas fisiográficas à elevação de nivel do mar.

Em todo o litoral norte paulista o mais belo exemplo de falésias em terraços marinhos holocênicos ocorre na Praia Vermelha do Norte (foto 41). 
Na Praia de Tabatinga, os restos de sedimentos paleolagunares exumados são sobrepostos e/ou interdigitados com depósitos marinhos holocênicos que se estendem para a pós-praia e para a planície costeira, chegando a formar pequenas falésias. Moradores antigos da praia comentam que há 20 anos, a praia se estendia por cerca de 100 a $120 \mathrm{~m}$ para dentro do mar e havia altos terraços arenosos semelhantes aos que ocorrem em Itaguaré (foto 35).

Outra área que merece atenção, devido à intensa erosão que está sofrendo e também porque tem sido objeto de estudo da autora desde meados da década de 80 , é a Praia de Caraguatatuba. A erosão ocorre ao longo de toda a praia, sendo mais conspícua em zonas de sotamar de células de deriva litorânea. Freqüentemente, parece haver superposição de causas antrópicas sobre causas naturais. Dentre as causas antrópicas podem ser citadas as construções de espigões, de enrocamentos e de canais de drenagem no setor norte da praia, além dos desassoreamentos de desembocaduras fluviais e retirada de areia de praia. As duas últimas práticas são recentes na área. Os processos erosivos que ocorrem ao norte e na porção central da praia são facilmente explicados pelas causas naturais e antrópicas citadas (19a e 19b). Entretanto, a acentuada erosão na praia que bordeja a planicie de maré (fotos 38 e 42a), francamente deposicional e completamente abrigada da ação das ondas (foto 20), não é tão facilmente explicada. Em parte pode ser devida à retenção de sedimentos nas estruturas ao norte da praia (fotos 19a e 19b)e à retirada de areia de praia. Pode estar também associada a mudanças locais na incidencia de ondas, provocando a formação de pequenas células de rumo norte, interceptando ou deslocando o transporte de sedimentos para a planicie de maré. Maior assoreamento na desembocadura do Rio Juqueriquerê, por exemplo, poderia causar a formação de barras arenosas (SOUZA, 1990) as quais, por sua vez, poderiam provocar mudanças no ângulo de incidência das ondas e inversão no rumo da deriva litorânea. Isso pode estar ocorrendo no segmento entre o Rio Juqueriquerê e o extremo sul da praia, como se observa nas fotos aéreas de 1994 e no campo, com a forte retrogradação da praia sobre o mangue a sua retaguarda e exumação e escarpamento de depósitos marinhos holocênicos na antepraia (foto 38). Os resultados obtidos com o método de TAGGART \& SCHWARTZ-modificado também sugerem a ocorrência de uma zona de divergência de células nesse local.

No extremo sul da Praia de Caraguatatuba, onde a planicie de maré é melhor desenvolvida, também estão ocorrendo fortes transformações e erosão acentuada. Em 1985 (foto 42b) a praia era composta de areias grossas a médias, pobremente 
selecionadas e apresentava alto mergulho (SOUZA, 1990), características essas típicas de praias que bordejam planícies de maré arenosas (ZENKOVITCH, 1967, apud SOUZA \& FURTADO, 1987). Atualmente, a praia apresenta baixa inclinação e areias finas a muito finas, muito bem selecionadas (foto $42 a$ ), semelhantes às caracteristicas encontradas por SOUZA (1990, 1995a) para a planicie de maré. Além disso, durante as preamares de sizígia ela fica quase totalmente inundada. Portanto, a praia que havia no local em 1985 desapareceu por completo pelo avanço da planície de maré. A casa vista na foto $42 a$ é de um hotel construído no início da década de 60 , a algumas dezenas de metros da planície de maré.

Em Caraguatatuba poderia também estar ocorrendo déficit sedimentar. Em 1967 ocorreram catastróficos escorregamentos que resultaram no encobrimento de parte da cidade por cerca de 2 milhões de toneladas de materiais rudáceos provenientes das encostas da Serra do Mar (PETRI \& SUGUIO, 1971, apud SOUZA, 1990). Isto ocorreu principalmente ao norte, com esses materiais chegando rapidamente à praia. Esses sedimentos foram sendo retrabalhados, propiciando o desenvolvimento de barras e pontais arenosos no extremo norte da praia (CRUZ et al., 1985). Entretanto, em meados da década de 70 três espigões foram construidos para tentar conter a erosão na área. Isto significa que a maior parte da carga sedimentar lançada em 1967 já havia sido remobilizada e provavelmente levada para o sul pelas correntes de deriva litorânea. Percebe-se também, pela análise de fotos aéreas de várias épocas, que a década de 70 foi um marco na sedimentação da planície de maré, com bom desenvolvimento de amplas barras arenosas e da praia de contorno, cuja largura medida em fotos aéreas de detalhe era de cerca de 40 $\mathrm{m}$. Na década de 80 , porém, a praia apresentava apenas $12 \mathrm{~m}$ (medidas de campo de SOUZA, 1990). Atualmente quase não há praia, com cerca de 1-2 $\mathrm{m}$ ficando ainda emersos. Assim, grande parte daqueles sedimentos não ficou retida nas praias e pode ter sido transportada para o largo da Enseada de Caraguatatuba ou para fora dela (por exemplo, para o Canal de São Sebastião). Deste modo, além das intervenções antrópicas, outras forças também parecem estar atuando nas modificações da área, as quais não estão deixando a praia retomar seu equilíbrio. Essas forças poderiam estar ligadas à elevação atual do nível relativo do mar.

No setor VII também são encontradas plataformas de abrasão marinha, desenvolvidas durante o Holoceno, com evidências de retomada erosiva (foto 43). 


\section{2. AVALIAÇÃO DA REGRA DE BRUUN ATRAVÉS DA COMPARAÇÃO DE CARTAS BATIMÉTRICAS DO LITORAL PAULISTA}

A Regra de Bruun (BRUUN, 1962), muito discutida e amplamente aceita, tenta explicar o que acontece com o perfil praial em uma costa submetida à elevação de nível do mar, independente da escala temporal do fenômeno. De acordo com essa regra haveria um deslocamento do perfil praial rumo ao continente por erosão da parte superior da praia, com a transferência do material erodido para o fundo marinho adjacente, até o limite entre o litoral e a costa afora (limite de deposição dos materiais terrigenos). Conseqüentemente, haveria a elevação do fundo marinho adjacente em magnitude igual à elevação de nível do mar, mantendo-se constante a profundidade da água.

Assumindo-se como verdadeiros a Regra de Bruun, a elevação de nível do mar durante pelo menos os últimos 50 anos (intervalo de alcance das séries temporais analisadas por MESQUITA \& HARARI, 1988) e o déficit sedimentar generalizado que parece estar ocorrendo ao longo do litoral paulista, pode-se prever que tenham ocorrido mudanças na sedimentação da plataforma continental adjacente. Deve-se admitir também, que as eventuais perdas naturais de sedimentos para outros depósitos sejam despreziveis, pois não há dunas ativas no Estado e os rios são, em sua maioria, de médio a pequeno portes. Poderia haver alguma retenção de sedimentos nos mangues, os quais são importantes apenas no litoral sul e no Estuário Santista. Por outro lado, as dragagens na plataforma continental que poderiam modificar a geometria da topografia de fundo são raras e restritas à área do canal de acesso ao porto de Santos.

As variações na sedimentação que vem ocorrendo na plataforma continental durante as últimas quatro décadas foram analisadas através da comparação de perfis traçados perpendicularmente à linha de costa, desde a praia até a isóbata de $50 \mathrm{~m}$, sobre as cartas náuticas 1700 e 1600, nas suas edições antigas (1939-1972 e 1938-1964) e recentes (1994 e 1993). A localização dos perfis traçados em cada setor morfodinâmico encontra-se nas figuras $81,82,83,84,85$ e 86 . Cada perfil foi espacialmente representado em um gráfico (figuras $87,88,89,90,91$ e 92), elaborado sem escala horizontal.

Comparando-se os gráficos obtidos, duas tendências são verificadas para a maioria dos perfis: o deslocamento generalizado das linhas de isóbatas rumo costa afora e a diminuição da declividade da plataforma continental interna. Essas duas tendências 
correspondem às modificações idealizadas por BRUUN (1962) como respostas à dinâmica sedimentar de costa submetida à elevação de nível do mar.

Além disso, verificou-se também que nas cartas mais antigas a isóbata de $5 \mathrm{~m}$ foi traçada apenas algumas vezes, embora esta profundidade estivesse presente em vários locais. Nas cartas recentes, por outro lado, ela encontra-se traçada de maneira bem clara e, em geral, bastante afastada da linha de praia. Embora as ténicas de mapeamento batimétrico tenham evoluído durante esses anos, é possível que a curva batimétrica de $5 \mathrm{~m}$ não tenha sido traçada por se encontrar muito próxima à praia e o seu traçado não seria factivel, considerando-se a escala dos mapas.

No setor morfodinâmico I (figuras 81 e 87), a declividade média na carta antiga era de $0,17 \%$ (variou de 0,09 a $0,26 \%$ ) e passou a $0,16 \%(0,11-0,19 \%)$ na carta mais recente. O deslocamento entre a linha de costa e a curva batimétrica de $10 \mathrm{~m}$ variou de 0 a $1,5 \mathrm{~km}$. $\mathrm{Em}$ dois perfis da llha Comprida (IC-B e IC-C) as variações foram negativas, ou seja, a distância das isóbatas em relação à praia diminuiu e a declividade aumentou. Isso pode ser explicado por deslocamentos das grandes células de corrente de retorno concentradas identificadas nesses locais. O perfil IC-C foi traçado no trecho onde a maior célula de corrente de retorno ocorre, tendo sido verificadas fortes irregularidades nas isóbatas (capítulo VI). Os deslocamentos da curva de $20 \mathrm{~m}$ foram de 2 a $7 \mathrm{~km}$. Para a curva de 50 m o deslocamento variou de 7,3 a $10,5 \mathrm{~km}$. Nos perfis IC-B e IC-C foram negativos para ambas as curvas. Na carta antiga a curva de $5 \mathrm{~m}$ aparece apenas na Praia do Leste, onde se obteve um deslocamento de $0,3 \mathrm{~km}$ em relação à carta mais recente.

No setor morfodinâmico II (figuras 82 e 88), as declividades médias da plataforma diminuiram de $0,30 \%(0,28-0,33 \%)$ para $0,15 \%(0,13-0,18 \%)$. Os deslocamentos foram de 1,5 a $2,6 \mathrm{~km}$ para a curva de $10 \mathrm{~m}, 5,2$ a 5,5 para a curva de $20 \mathrm{~m}$ e 8,7 a $10,2 \mathrm{~km}$ para a de $50 \mathrm{~m}$.

No setor morfodinâmico III (figuras 83 e 89 ), as declividades médias diminuiram de $0,19 \%(0,14-0,25 \%)$ para $0,17 \%(0,13-0,22 \%)$. Os deslocamentos foram de 0,3 a $1,4 \mathrm{~km}$ para a curva de $10 \mathrm{~m}, 0,3$ a $3,5 \mathrm{~km}$ para a curva de $20 \mathrm{~m}$ e $0,3 \mathrm{~km}$ para a curva de $50 \mathrm{~m}$. Valores negativos foram obtidos para os perfis IT (curvas de 10 e $50 \mathrm{~m}$ ) e PG-A e PG-B (curva de $50 \mathrm{~m}$ ).

No setor morfodinâmico IV (figuras 84 e 90), as declividades médias diminuiram de $0,33 \%(0,25-0,67 \%)$ para $0,30 \%(0,28-0,33 \%)$. Os deslocamentos foram de 2,7 a $3,8 \mathrm{~km}$ 
para a curva de $10 \mathrm{~m}, 0,9$ a $1,7 \mathrm{~km}$ para a curva de $20 \mathrm{~m}$ e 1,1 a $3 \mathrm{~km}$ para a curva de 50 $\mathrm{m}$.

No setor morfodinâmico $\mathrm{V}$ (figuras 85 e 91 ) as declividades médias diminuiram de $0,36 \%(0,31-0,51 \%)$ para $0,30 \%(0,15-0,93 \%)$. Os deslocamentos foram de 0 a $0,3 \mathrm{~km}$ para a isóbata de $5 \mathrm{~m}, 0,4$ a $2,7 \mathrm{~km}$ para a curva de $10 \mathrm{~m}, 0,3$ a $11,5 \mathrm{~km}$ para a curva de $20 \mathrm{~m}$ e 1,1 a $12,8 \mathrm{~km}$ para a curva de $50 \mathrm{~m}$.

O setor morfodinâmico VI não foi investigado porque se trata de uma área sujeita à dinâmica muito complexa do Canal de São Sebastião.

No setor morfodinâmico VII (figuras 86 e 92), as declividades médias diminuiram de $0,28 \%(0,10-0,48 \%)$ para $0,23 \%(0,09-0,39 \%)$. Os deslocamentos foram de 0 a $1,2 \mathrm{~km}$ para a curva de $10 \mathrm{~m}, 0,5$ a $3,7 \mathrm{~km}$ para a curva de $20 \mathrm{~m} \mathrm{e} 6,9$ a $17,1 \mathrm{~km}$ para a curva de $50 \mathrm{~m}$. Valores negativos ocorreram para a curva de $50 \mathrm{~m}$ nas praias de Mocoóca, Sapê e Ubatumirim. Na Praia da Fazenda foi obtido um valor negativo de $0,3 \mathrm{~km}$ na curva de 10 $\mathrm{m}$.

Portanto, verificou-se uma considerável modificação na batimetria de toda a plataforma continental interna paulista, ficando clara a tendência generalizada de deslocamento das curvas batimétricas no sentido costa afora e a conseqüente diminuição da declividade do fundo marinho, verificados para $76 \%$ dos perfis traçados. Essas variações são sugestivas de que o nivel do mar esteja em elevação, com conseqüente retenção de sedimentos no fundo submarino, e que os perfis praiais estejam ajustando-se paulatinamente. Além disso, elas poderiam explicar, pelo menos em parte, o déficit sedimentar identificado nas praias.

Obviamente, uma melhor avaliação dessas tendências seria possivel a partir do estudo de testemunhos de sondagens efetuados na plataforma continental interna e de datações absolutas dos sedimentos coletados. 


\section{CONSIDERAÇÕES FINAIS}

A figura 93 corresponde a um resumo de todas as características texturais dos sedimentos nos sete setores morfodinâmicos estudados, compreendendo as médias obtidas entre todas as amostras coletadas em cada setor.

Em todas as praias as distribuições granulométricas foram unimodais. As diferenças de energia de ondas entre as costas sul, central e norte de São Paulo, bem como a variabilidade de estados modais, são bastante claros quando as variações texturais de sedimentos dos setores morfodinâmicos são confrontadas. Nos setores I a IV predominam areias finas e muito bem selecionadas, simétricas e mesocúrticas. No setor $V$ as areias são principalmente muito finas a finas e muito bem selecionadas, simétricas e mesocúrticas. No setor $\mathrm{VI}$ as areias são predominantemente médias e moderadamente selecionadas, simétricas a positivas e mesocúrticas. No setor VIl são mais freqüentes as areias finas e médias e moderadamente selecionadas, simétricas e mesocúrticas. Em geral, do setor 1 para $\circ \mathrm{V}$ diminuem as freqüências de areias finas, ao mesmo tempo em que aumentam progressivamente as porcentagens de areias muito finas, médias e grossas. Neste mesmo sentido diminui o grau de seleção, com participação crescente de sedimentos moderadamente selecionados. Esta tendência é interrompida no setor II, onde as areias médias passam a ser tão importantes quanto as muito finas e finas, e a freqüência dos termos moderadamente selecionados ultrapassa a dos bem selecionados. No setor VII areias finas, médias e grossas apresentam freqüências semelhantes, tornando os sedimentos pior selecionados que os dos setores ao sul. O setor VI caracteriza-se por forte mudança no comportamento textural das praias.

A presença de sedimentos finos nos diferentes setores pode ser detectada através das variações de assimetria positiva, cuja freqüência é maior no setor l e depois vai decrescendo até o setor $V$, para aumentar no setor VI e novamente decrescer no setor VII. Os grandes canais de maré e rios no litoral sul e a presença de rios cada vez menores rumo ao norte devem ser os principais responsáveis por essas variações de assimetria. Os termos positivos encontrados no Canal de São Sebastião (setor VI) estão associadas às contribuições de materiais finos provenientes do Rio Juqueriquerê, que é o maior do litoral norte. Esta é, aliás, outra forte evidência de transporte para sul nesta área, isto é, da Enseada de Caraguatatuba rumo ao Canal de São Sebastião. 
Comparando-se apenas as freqüências de sedimentos leptocúrticos em cada setor observam-se oscilações, que sugerem variações nos níveis relativos de energia entre eles. Assim, nos setores I e III encontram-se os mais altos niveis de energia, nos setores II, IV, V e VIl a energia é intermediária, e no setor VI tem-se o mais baixo nivel de energia relativa.

Todas essas relações texturais estão também vinculadas à fisiografia da costa, mais aberta e de direção SW-NE ao sul e gradando para mais abrigada e/ou recortada rumo ao norte. Ficaram bem caracterizadas a maior dissipatividade do litoral entre liha Comprida $e$ Praia Grande, interrompida no setor II pela presença de praias mais abrigadas e com caracteristicas intermediárias e o aumento gradativo da refletividade rumo ao litoral norte, com praias dissipativas e intermediárias a dissipativas no litoral central do Estado, entre Santos e Boracéia, passando a praias intermediárias a reflexivas até o Canal de São Sebastião, para então entrar em um litoral (Caraguatatuba a Ubatuba) onde as praias apresentam-se, geralmente, em estados mistos entre intermediários a dissipativos ou reflexivos a intermediários. Como era esperado, o Canal de São Sebastião exibe um regime de circulação especial, bem evidenciado no comportamento de seus sedimentos, que refletem a baixa energia de ondas. A llha de São Sebastião influi na dinâmica de circulação de toda a parte sul do setor VII, atuando como anteparo à incidência de ondas de SSW, S, SSE e SE.

Os novos resultados aqui apresentados estão de acordo com a compartimentação morfodinâmica previamente elaborada por SOUZA \& SUGUIO (1996a).

No tocante à circulação costeira foram evidenciados transportes de sentidos opostos em praticamente todas as praias do Estado, atuando simultaneamente. Em geral, foi possivel identificar grandes segmentos de transporte resultante cada qual contendo pequenas células individualizadas. Este tipo de padrão também foi encontrado por outros autores como STAPOR \& MAY (1983).

Originalmente, os trabalhos não foram feitos com o objetivo de investigar situaçōes meteorológicas diferentes em cada praia, mas sim confrontar estações climáticas distintas. Apesar disso, foi possivel comparar dados levantados sob condições de frentes frias e tempo bom, e também sob diferentes fases de maré (sizígia e quadratura), para muitas praias. As praias estudadas sob condiçōes de tempo opostas, submetida a frente fria no inverno e tempo bom no verão, ou vice-versa, foram: 
Setor I- Ilha Comprida (parcialmente tempo instável) e Leste;

Setor II- Rio Verde-Itacolomi e Una-Sul;

Setor III- nenhuma;

Setor IV- São Vicente, Itararé, Santos, Guaiúba, Tombo, Astúrias, Pitangueiras, Enseada, Perequê e Pernambuco;

Setor V- Bertioga, Boiçucanga, Maresias, Santiago-Toque Toque Pequeno, Guaecá e Barequeçaba;

Setor $V$ - nenhuma;

Setor VII- Maranduba-Sapê-Lagoinha, Fortaleza-Vermelha-Dura-Lázaro, Enseada, Toninhas-Grande.

As praias nas quais as condiçôes eram de tempo instável no inverno e tempo bom no verão, ou vice-versa, foram:

Setor I- Juréia;

Setor II- Una-Norte, Guaraú;

Setor III- Peruibe, Itanhaém e Praia Grande;

Setor IV- nenhuma;

Setor V-Boracéia;

Setor VI- nenhuma;

Setor VII- Caraguatatuba, Itaguá-iperoig, Puruba, Ubatumirim e Fazenda.

As praias de São Lourenço e Itaguaré encontravam-se em condições de frente fria (inverno) e de tempo instável (verão). Nas demais praias (São Pedro-lporanga, Guaratuba, Juquehy, Baleia, Balneário, São Francisco, Cigarras, Martim de Sá, Massaguaçu, Mocoóca, Tabatinga, Perequê-Açu/Barra-Seca, Vermelha do Norte, Itamambuca, Félix e Prumirim) as condições foram semelhantes, em condições de tempo bom ou de tempo instável em ambas as etapas.

As praias que apresentaram alterações ou inversões no sentido de células entre o inverno e o verão pelo método de TAGGART \& SCHWARTZ-modificado foram: Iha Comprida (localmente), Leste, Juréia, Peruibe, Itanhaém, Praia Grande (localmente), Itararé, Pitangueiras, Bertioga, São Lourenço, Boracéia, Baleia, Boiçucanga, Maresias, Guaecá, Caraguatatuba (localmente), Martim de Sá-Massaguaçu, Mocoóca-Tabatinga, Itamambuca, Félix-Prumirim, Ubatumirim, Fazenda. 
As praias onde ocorreram as mesmas tendências de atuação de células de deriva litorânea nas duas etapas de amostragem foram: Rio Verde, Una-Sul, Una-Norte, São Vicente, Santos, Guaiúba, Astúrias, Enseada, Tombo, Itaguaré, Guaratuba, Juquehy, Santiago e Toque-Toque, Barequeçaba, Maranduba-Sapê-Lagoinha, Fortaleza-Vermelha de Fortaleza-Dura- Lázaro, Toninhas-Grande, Iperoig-Itaguá, Vermelha do Norte e Puruba.

Comparando esses resultados percebe-se que não foi encontrada uma tendência únicas que possa caracterizar predomínio de inversões para as praias amostradas sob condições meteorológicas diferentes. Apenas oito delas mostraram esta tendência: lliha Comprida, Leste, Itararé, Pitangueiras, Bertioga, Boiçucanga, Maresias e Guaecá. Por outro lado, dentre as praias que estiveram sujeitas às mesmas condições meteorológicas apenas quatro não sofreram inversões de deriva litorânea: Guaratuba, Juquehy, PerequêAçu-Barra-Seca e Vermelha do Norte. Dentre as que se encontravam sob condições de frente fria e tempo instável, uma sofreu alterações (São Lourenço), mas a outra não (Itaguaré). Das praias amostradas sob tempo instável e tempo bom, oito sofreram inversões (Juréia, Peruibe, Itanhaém, Praia Grande, Boracéia, Caraguatatuba, Ubatumirim e Fazenda) e três não (Una-Norte, Iperoig-Itaguá, Puruba). Dentre essas a Praia Grande e Caraguatatuba sofreram apenas uma pequena inversão.

Portanto, embora se acredite que pelo menos nas praias mais abertas do litoral sul e central essas inversões sejam mais suscetíveis de ocorrer, não foram identificadas tendências gerais, como aquela obtida por BOMTEMPO (1991) para as praias de Rio Verde e Una-Sul, e por HARARI \& CACCIARI (1991) para a praia de As Ilhas (próxima a Juquehy). Por outro lado, em HIDROCONSULT (1974) os resultados obtidos com correntes medidas na área entre as praias do Tombo e Enseada (Guarujá) foram semelhantes sob condições meteorológicas distintas.

Alguns aspectos podem ser levantados para explicar a ausência de tendências gerais nos resultados obtidos nesta pesquisa.

1. Na costa mais abrigada e recortada do litoral norte os trens de ondas incidentes sofrem tantas interferências que, mesmo pequenas variações na direção do ângulo das ondulações, podem causar mudanças nos sentidos das correntes de deriva litorânea. Em costas abertas pequenas mudanças na direção dos trens de ondas incidentes, ou a interferência de ondas secundárias, podem formar células locais. 
2. Modificações temporárias na topografia de fundo, como as que ocorrem após as tempestades como, por exemplo, o assoreamento junto às desembocaduras fluviais e lagunares ou a acumulação de sedimentos em barras submersas, podem também alterar 0 ângulo de incidência das ondas por tempo limitado, gerando células diferentes.

3. Na antepraia não estariam ocorrendo apenas transportes unidirecionais, mas existiriam células bem individualizadas capazes de imprimir modificações efetivas nas características morfotexturais da praia. BOMTEMPO (1991) e HARARI \& CACCIARI (1991) trabalharam com medições de correntes ao largo ou no início da zona de arrebentação e determinaram os seus rumos predominantes. Embora possa haver um único sentido predominante de transporte ao longo da praia, as ondas secundárias, por exemplo, como as ondas de ressonância (edge waves), que atuam na zona de surfe, podem também estar interferindo e contribuindo para modificar as características da praia, como o fazem gerando topografias ritmicas (cúspides).

4. As interferências antrópicas também são muito importantes, como as estruturas rígidas perpendiculares ou paralelas à linha de costa, ou a limpeza pública das praias e a remoção da capa superficial de areias (evento sedimentar mais recente).

5. É possível que as amostras coletadas não representem o evento sedimentar correlato às condições meteorológicas vigentes à época da amostragem. Isso pode ocorrer quando a capa sedimentar superficial foi removida ou misturada por atividade antrópica, as condições meteorológicas foram recém-instaladas e o procedimento de amostragem foi inadequado para este fim. Na verdade, o objetivo das amostragens, neste trabalho, era o de reconhecer o comportamento morfológico e textural das praias em duas estações diferentes e não identificar um ciclo sedimentar relacionado a determinadas condições meteorológicas. Isso deveria ser feito através de monitoramento, com maior controle das condições atmosféricas e coleta da lâmina superficial ao longo de toda a praia. Mesmo assim, muitos erros podem ser envolvidos neste tipo de amostragem, pois um determinado evento sedimentar não recobre uniformemente toda a superfície da praia.

O método de TAGGART \& SCHWARTZ-modificado mostrou-se eficiente na identificação de pequenas e grandes células de transporte costeiro, principalmente em praias dissipativas de alta energia, com acentuada homogeneidade morfológica e textural. Além disso, permitiu identificar processos diferentes que não poderiam ser diagnosticados com o uso do método não modificado como, por exemplo, o engrossamento dos 
sedimentos em zonas de sotamar e o decréscimo do grau de seleção em sedimentos próximos a locais de aportes fluviais ou lagunares. Por outro lado, a curtose foi usada com sucesso como indicadora de nível de energia relativa ao longo da praia. $O$ método de MCLAREN foi particularmente útil na identificação de tendências regionais de transporte e também na caracterização de zonas com predominância de erosão ou deposição. Os casos $B(F / M / N)$ foram os predominantes em todos os setores, permitindo uma comparação com o método de TAGGART \& SCHWARTZ-modificado. $O$ uso de produtos de sensoriamento remoto, embora atualmente muito difundido, demonstrou ter eficiência limitada pois, em geral, os produtos são gerados em meses de inverno e sob condições de tempo bom.

As causas da erosão na costa paulista podem ser atribuidas a fatores naturais e antrópicos. Dentre os fatores naturais mais prováveis estão os efeitos da dinâmica de circulação costeira e a elevação atual de nível do mar. Se uma praia apresenta déficit de sedimentos, os efeitos da elevação de nível do mar e dos processos erosivos atuantes dentro de cada célula de deriva litorânea serão amplificados. Foi possivel identificar a predominância de processo erosivo em zonas de barlamar ou centros de divergência de células de deriva litorânea em grande parte das praias estudadas. Além disso, a maioria das praias paulistas parece sofrer de déficit sedimentar. Poucas praias sugerem estar em equilibrio relativo, como as praias de Rio Verde, Itararé e Enseada (Guarujá). Essa situação generalizada de balanço sedimentar negativo também pode ser considerada uma causa natural de erosão costeira e, por sua vez, poderia ser conseqüência dos dois fatores naturais citados anteriormente e ainda de atividades antrópicas, como a extração de areia das praias e dos rios. Se a Regra de Bruun for realmente válida, então as fortes modificações observadas na configuração das curvas batimétricas nas últimas cinco décadas, poderiam explicar o déficit sedimentar das praias, que seria provocado pela intensa deposição e retenção de sedimentos no fundo marinho adjacente às praias. Por outro lado, as intervenções antrópicas são inúmeras e parecem estar exacerbando processos erosivos ao longo de toda a costa paulista. A construção de estruturas rígidas sobre a praia ou em área muito próxima a ela e as alterações provocadas pela urbanização das áreas costeiras são os principais fatores antrópicos geradores de processos erosivos. Essas intervenções são particularmente conspícuas na Baixada Santista e no litoral entre São Sebastião e Caraguatatuba, sendo difícil definir os "pesos relativos" entre os papéis desempenhados pelos mecanismos naturais e antrópicos. Nos dois extremos do Estado os 
processos naturais parecem ser os mais importantes no desenvolvimento de processos erosivos, uma vez que as atividades antrópicas são, a princípio, insuficientes para desencadear a maioria deles.

Finalmente, comparando o comportamento das praias e dos terraços de cristas praiais holocênicos presentes nas planícies costeiras de todo o Estado de São Paulo, pode-se sugerir que os sistemas de ondas atuais, bem como toda a dinâmica atmosférica, vem atuando de forma muito semelhante durante pelo menos todo o Holoceno, pois não há variações morfológicas entre as antigas cristas praiais e as atuais. Neste contexto é interessante observar que todas as praias em forma de "cabo de guarda-chuva" presentes no litoral paulista (Astúrias, Perequê, Caraguatatuba e Itaguá-Iperoig) têm orientação N-S e apresentam estados morfodinâmicos mistos (intermediário a dissipativo de baixa energia), sendo abrigadas das ondas mais enérgicas de SW-SSW-S-SSE e recebendo mais frontalmente apenas as ondas de E-SE. Essas características não parecem ter mudado desde o Holoceno. As praias com orientação E-W (Santos, Barequeçaba), que recebem mais frontalmente os sistemas de ondas gerados durante as frentes frias, são e sempre foram dissipativas de baixa energia. Da mesma forma, as orientadas segundo NE-SW são geralmente dissipativas de alta energia, caracteristicas estas também encontradas nas cristas praiais holocênicas que jazem em suas planícies costeiras. 


\section{REFERÊNCIAS BIBLIOGRÁFICAS}

ALMEIDA, F.F. 1964. Os fundamentos geológicos do relevo paulista. Bol. IGG, 41: 169-263.

ANGULO, R.J. 1993a. A ocupação urbana no litoral paranaense e as variações da linha de costa. Bol. Paranaense Geoc., 41: 73-81.

ANGULO, R.J. 1993b. Variações na configuração da linha de costa no Paraná nas últimas quatro décadas. Bol. Paranaense Geoc., 41: 52-72.

ANGULO, R.J. 1995. Natural dynamics and land use on coast of Paraná, Brazil: background and prospects. In: Coastal Change - Bordomer 95, Bordeaux. Actes/Proceedings, Tome I, p. $427-434$.

ANGULO, R.J. 1996. Problemas na terminologia de ambientes e subambientes litorâneos clásticos dominados por ondas. Bol. Paranaense Geoc., 44 (no prelo).

BARCELOS, J.H. 1975. Sedimentação e Subambientes Deposicionais da llha Comprida, SP. Dissertação de Mestrado, Inst. Geociências-USP.

BARCELOS, J.H.; SUGUIO, K. \& COIMBRA, A.M. 1976. Sedimentação e subambientes deposicionais da liha Comprida, São Paulo. In: Congr. Bras. Geol., 29, São Paulo. Anais, v. 2, p. 107-135.

BASTOS, A.C. \& SILVA, C.G. 1996. Evidências de períodos erosivos cíclicos na planície de cristas de praia do Rio Paraíba do Sul. In: Congr. Bras. Geol., XXXIX, Salvador. Anais, v. 4, p. 379-383.

BIGARELLA, J.J.; SALAMUNI, R. \& MARQUES, P.L. 1961. Método para avaliação do nível oceânico à época da formação dos terraços de construção marinha. Bol. Paran. Geografia. 4/5.

BIGARELLA, J.J.; MARQUES, P.L.; SALAMUNI, R. \& VIANA, R. 1966. Contribuição ao estudo de sedimentos praiais recentes. III. Características texturais das praias e terraços da região litorânea paulista. Bol. Univ. Fed. Paraná, Geogr. Fis., 7, 34 p.

BIRD, E. C. F. 1986. Potential effects of sea level rise on the coasts of Austrália, Africa, and Asia. In: TITUS, J. G. (ed.), Effects of Changes in Stratospheric Ozone and Global Climate. Volume 4: Sea Level Rise. p. 83-98.

BITTENCOURT, A.C.S.P. 1992. A questão da predominância ou não de valores negativos de assimetria das distribuições granulométricas para os depósitos da face da praia - Uma polêmica revisada. Rev. Bras. Geoc., 22(1): 107-111.

BITTENCOURT, A.C.S.P.; VILLAS BOAS, G.S. \& FARIAS, F.F. 1992. Variações direcionais nos parâmetros granulométricos: um indicador apropriado para o sentido da deriva litorânea. Rev. Bras. Geoc., 22(1): 100-106.

BOMTEMPO, V. L. 1991. Características hidráulicas e sedimentológicas do trecho do Itoral sul do Estado de São Paulo. Dissertação de Mestrado - COPPE/UFRJ. 302p.

BOWEN, A.J. \& INMAN, D.L. 1969. Rip currents. Laboratory and field observations. Jour. Geophys. Res., 74 (23): 5479-5490.

BRUUN, P. 1962. Sea level, rise as a cause of shore erosion. Jour. Waterways and Harbor Div., 88:117-130.

BRUUN, P. 1988. The Bruun Rule of erosion by sea-level rise: a discussion on large-scale twoand three-dimensional usages. Jour. Coastal Res., 4: 627-648. 
BRUUN, P. \& SCHWARTZ, M. L. 1985. Analytical predictions of beach profile change in response to a sea level rise. Zeit. Geomorph. Suppl.-Bd. 57: 33-50.

CAZZOLI, S.V. 1996. Variações temporais e espaciais de um perfil de praia - Itanhaém - São Paulo. In: Congr. Bras. Geol., XXXIX, Salvador. Anais, v. 4, p. 392-396.

CAMPANHA, G.A.C.; ENS, H.H. \& PONÇANO, W.L. 1994. Análise morfotectônica do Planalto do Juqueriquerê, São Sebastião. Rev. Bras. Geoc., 24 (1): 32-42.

CARTER, R. W. G. 1988. Coastal Environments. An Introduction to the Physical, Ecological and Cultural Systems of Coastlines. Academic Press. 617p.

CEPA/USP - COMISSÃO DE ESTUDOS DE PROBLEMAS AMBIENTAIS/USP. 1994. Extração de Areias das Praias - Municipio de Santos. Relatório de Visita e Parecer Técnico. 11 p. + Anexos.

COIMBRA, A. M.; FURTADO, V. V.; TESSLER, M. G.; YAMAMOTO, M. F. \& TODESCHINI, E. 1980. Dispersão dos sedimentos de superfície de fundo na plataforma continental interna do Estado de São Paulo. In: Congr. Bras. Geol., 31, Camboriú. Anais, v. 1, p. 557-568.

COMMISSÃO GEOGRAPHICA E GEOLÓGICA DO ESTADO DE SÃO PAULO (C.G.G.). 1915 Exploração do Littoral. $1^{a}$ secção. Cidade de Santos à fronteira do Estado do Rio de Janeiro.

COMMISSÃO GEOGRAPHICA E GEOLÓGICA DO ESTADO DE SÃO PAULO (C.G.G.). 1920. Exploração do Littoral. $2^{a}$ secção. Cidade de Santos à fronteira do Estado do Paraná.

COOK, D.O. \& GORSLINE, D.S. 1972. Field observations os sand transport by shoaling waves. Mar. Geol. 13: 31-55.

CRUZ, O.; SUGUIO, K. \& EICHLER, B.B. 1985. Sedimentação acelerada de pontais e barras arenosas na Enseada de Caraguatatuba, SP: causas naturais e artificiais. Bol. IO-USP, 33(1): 39m53.

CTH-USP/DAEE. 1973. Observação das características das ondas do mar de Cananéia. Relatório de Projeto. Laboratório de Hidráulica da Escola Politécnica -USP, DAEE, 40p.

CTH-USPIDAEE. 1976. Relatório Final dos Estudos de Recuperação e Proteção da Praia de São Vicente. Vol. I, 19 p. + Anexos.

DALRYMPLE, R.A. 1975. A mechanism for rip current generation on a open coast. Jour. Geophys. Res., 80 (24): 3485-3487.

DAVIES, J.L. 1960. A morphogenic approach to world shorelines. Zeit. Geomorph. Band 8: $127-142$.

DAVIES, J.L. 1977. Geographical Variations in Coastal Development. In: K.M. Clayton (org.). Geomorphology. Text Series 4, London, Longman, 204 p.

DEFFONTAINES, P. 1935. Regiões e paisagens do Estado de São Paulo. Geografia, 1 (2): 167-179.

DOMINGUEZ, J.M.L. 1995. A erosão da linha de costa na região nordeste do Brasil: uma abordagem do problema a partir da compreensão da evolução costeira. In: Simp. Processos Sedimentares e Problemas Ambientais na zona Costeira Nordeste do Brasil, Recife. Anais, p. 71-73.

FINKELSTEIN, K. 1982. Morphological variations and sediment transport in crenulate-bay beaches, Kodiak Island, Alaska. Mar. Geol., 47: 261-281.

FOLK, R. L. \& WARD, W. C. 1957. Brazos river bar: a study in the significance of grain size parameters. Jour. Sed. Petrol., 27: 3-26. 
FONZAR, B.C. 1994. A circulação atmosférica na América do Sul: os grandes sistemas planetários e subsistemas regionais que atingem o continente (localização e trajetórias). Cad. Geoc., Rio de Janeiro, 11: 11-33.

FREITAS, R.O. 1947. Geologia e Petrologia da llha de São Sebastião. Fac. Fil. Ciênc. e Letras -USP, Bol. 85, Geologia 3, 244p.

FREITAS, R.O. 1960a. Mineralogia e geologia de areias de praia entre São Sebastião e Caraguatatuba. E.E. São Carlos-USP, Geologia $n^{\circ} 12$, Publ. $n^{\circ} 31,82 p$.

FREITAS, R.O. 1960b. Mineralogia e geologia de areias de praia de Caraguatatuba à Ubatuba. E.E. São Carlos-USP, Geologia $n^{0} 11$, Publ. $n^{0} 30,91 p$.

FRIHY, O.E. \& DEWIDAR, K.M. 1993. Influence of shoreline erosion and accretion on texture and heavy compositions of beach sands of the Burulls coast, noth-central Nile Delta, Egypt. Mar. Geol., 114 (1/2): 91-104.

FÚlFARO , V. J. \& PONÇANO, W. L. 1974. Recent tectonic features in the Serra do Mar region, and its importance to engineering geology. In: I.A.E.G. Congr., II, São Paulo. Proceedings, v. I, p. \|l-7.1 a \|l-7.5.

FURTADO, V.V. 1978. Contribuição ao Estudo da Sedimentação Atual do Canal de São Sebastião, Est. SP. Tese Doutorado, IG-USP, 2v. 110 p.

FURTADO, V.V.; BICEGO, M.C.\& WEBER, R.R. 1987. Modelo de dispersão de óleo na região do Canal de São Sebastião. In: Simp. Ecossistemas da Costa Sul e Sudeste Brasileira, $1^{\circ}$, Cananéia. Publ. ACIESP, 54-1I (2), 371-388.

GIANNINI, P. C. F. 1987. Sedimentação Quaternária na Planície Costeira de Peruíbe-Itanhaém (SP). Dissertação de Mestrado, Inst. Geociências-USP. 2 volumes.

GIANNINI, P. C. F. 1993. Sistemas Deposicionais no Quaternário Costeiro entre Jaguaruna e Imbituba, SC. Inst. Geociências-USP. Tese de Doutorado, 2 volumes.

GORNITZ, V. 1995. Sea-level rise: A review of recent past and near-future trends. Earth Surf. Processes and Landform, 20: 7-20.

GUILLÉN, J. \& JIMENEZ, J.A. 1995. Processes behind the longshore variations of the sediment grain size in the Ebro Delta coast. Jour. Coastal Res., 11 (1): 205-218.

GUZA, R.T. \& INMAN, D.L. 1975. Edge waves and beach cusps. Jour. Geophys. Res., 80 (21): 2997-3011.

HARARI, J. \& CACCIARI, P.L. 1991. Levantamento preliminar das condições oceanográficas físicas n'As Ilhas. In: Simp. Oceanografia do IO-USP, 2. Boletim de Resumos, p. 136.

HARARI, J. \& CAMARGO, R. 1995. Tides and mean sea level variabilities in Santos (SP), 1944 to 1989. Rel. Interno do IO-USP, 36:1-15.

HEALY, T, 1996. Sea level rise impacts on nearshore sedimentation: an overview. Geol. Rundsch., 85: 546-553.

HIDROCONSULT. 1974/1975. Investigação e Estudos realizados para o Projeto do Sistema de Disposição Oceânica dos Esgotos de Santos e São Vicente. Vol. I e ll (Texto e Mapas).

HUGHES, M.G. \& COWELL, P.J. 1987. Adjustment of reflective beaches to waves. Jour. Coastal Res., 3 (2): 153-167.

JACOBSEN, E.E. \& SCHWARTZ, M.L. 1981. The use of geomorphic indicators to determine the direction of net shore-drift. Shore \& Beach, 49: 38-43.

JONHSON, D.W. 1919. Shore Processes and Shoreline Development. J. Wiley (ed.), 584p. 
KOMAR, P.D. 1991. Handbook of Coastal Processes and Erosion ( $4^{\text {th }}$ edition). CRC Press. 297 p.

KOMAR, P.D. 1995. Coastal processes and susceptibilities of properties to erosion. In: Coastal Change - Bordomer 95, Bordeaux. Actes/Proceedings, Tome I, p.183-200.

KOMAR, P.D. \& ENFIELD, D.B. 1987. Short-term sea-level changes and coastal erosion. In: Sea-Level Flutuation and Coastal Evolution. SEPM, Spec. Publ. $n^{\circ}$ 41, p. 17-27.

LEAL NETO, A.C. \& ACCETA, D. 1995. Recentes medições de ondas desenvolvidas pelo INPH. In: Sem. Ondas e Marés Oceânicas, $1^{\circ}$, Arraial do Cabo (RJ). Resumos, p. 28-30.

MANSO, V.A.V.; COUTINHO, P.N.; MEDEIROS, A.B.; BORBA, A.L.S.; LIRA, A.R.A.; PEDROSA, F.J.A.; MARTINS, H.A.; CHAVES, N.S.; DUARTE, R.X.; IVO, P.S.; LIMA, A.T.O. \& ALMEIDA, L.E.S.B. 1996. Proposta para a contenção da erosão marinha na praia da Boa Viagem - Recife (PE). In: Congr. Bras. Geol., XXXIX, Salvador. Anais, v. 4, p. 489-492.

MARTIN, L. \& SUGUIO, K. 1978. Ilha Comprida: um exemplo de ilha-barreira ligado às flutuações do nivel marinho durante o Quaternário. In: Congr. Bras. Geol., 30. Anais, v. 2, p. 905-912.

MARTIN, L.; SUGUIO, K. \& FLEXOR, J.M. 1988. Hauts niveaux marins pléistocènes du littoral brésilien. Palaeogeogr., Palaeoclim., Palaeoecology, 68: 231-239.

MCCAVE, I.N. 1978. Grain-size trends and transport along beaches: example from eastern England. Mar. Geol., 28: M43-M51.

MCLAREN, P, 1981. An interpretation of trends in grain size measures. Jour. Sed. Petrol., 51(2): 611-624.

MCLAREN, P. \& BOWLES, D. 1985. The effects of sediment transport on grain-size distributions. Jour. Sed. Petrol., 55 (4): 457-470.

MENDES, A.C. \& FARIA Jr., L.E.C. 1996. Processos sedimentares e a erosão costeira no Amapá. In: Congr. Bras. Geol., XXXIX, Salvador. Anais, v. 4, p. 460-463.

MENEZES, M. P. 1994. A Reconstituição da Dinâmica Sedimentar Costeira da Estação Ecológica de Juréia-Itatins (SP) e sua Correlação com a Atividade Humana Local. Dissertação de Mestrado em Ciência Ambiental, USP, 2 vol.

MESQUITA, A. R. 1994. Variações no nivel do mar nas costas brasileiras. Afro-Amer. Gloss News, 1(1): 3-4.

MESQUITA, A. R. 1995. Variações do nivel médio do mar nas escalas decadal e interdecadal na costa sudeste do Brasil. In: Sem. Ondas e Marés Oceânicas, $1^{\circ}$, Arraial do Cabo (RJ). Resumos, p. 52-53.

MESQUITA, A. R. \& HAHARI, J. 1988. Marés e nivel médio do mar nas costas brasileiras e no Atlântico Sul. Bol. IG-USP, Publ. Espec. 6, p. 17-20.

MESQUITA, A.R.; HARARI, J. \& FRANÇA, C.A.S. 1995. Interannual variability of tides and sea level at Cananéia, Brazil, from 1955 to 1990. In: Simp. Oceanografia, 2, São Paulo. Publ. Espec. do IO-USP, (11):11-19.

MIOTO, J.A. 1990. Tentativa de zoneamento sísmico do sudeste brasileiro. Bol. Soc. Bras. Geol., 11: 33-45.

MUEHE, D. 1994. Geomorfologia Costeira. In: A. J. T. GUERRA \& S. B. CUNHA. Geomorfologia: Uma Atualização de Bases e Conceitos. Ed. Bertrand S.A. 
MUEHE, D. \& CARVALHO, V. G. DE. 1993. Geomorfologia, cobertura sedimentar e transporte de sedimentos na plataforma continental interna entre a Ponta de Saquarema e o Cabo Frio (RJ). Bol. IO-USP, 41(1/2):1-12.

NAKAZAWA, V. A.; FREITAS, G. G. L. \& DINIZ, N. C. 1994. Carta Geotécnica do Estado de São Paulo. Escala 1:500.000. IPT. v. I e II.

NODA, E.K. 1971. State-of-the-art of littoral drift measurements. Shore \& Beach, 39: 35-41.

NORDSTROM, K.F. 1977. The use of grain-size statistics to distinguish between high-andmoderate energy beach environments. Jour. Sed. Petrol., 47 (3): 1287-1294.

PIRES NETO, A.G. \& OLIVEIRA, A. 1976. Granulometria de sedimentos praiais do litoral centro-norte do Estado de são Paulo, entre Bertioga e São Sebastião. Noticia Geomorfológica Campinas, 16(31):75-105.

PONÇANO, W.L. \& FÚLFARO, V.J. 1976. Sedimentação atual do estuário e Baía de Santos: um modelo geológico aplicado a projetos de expansão da zona portuária. In: Congr. Bras. Geol. Eng., ABGE, $1^{\circ}$, Rio de Janeiro. Anais, v.2, p. 67-90.

PONÇANO, W.L.; CARNEIRO, C. D. R.; BISTRICHI, C. A.; ALMEIDA, F. F. M. \& PRANDINI, F. L. 1981. Mapa Geomorfológico do Estado de São Paulo. Escala 1:500.000. IPT. 2v.

PSUTY, N.P. 1988. Sediment budget and dune/beach interaction. Jour. Coastal Res., Special Issue, 3: 1-4.

QUATRO RODAS. 1994. Guia de Praias da Quatro Rodas. Editora Abril. 210p.

SANT'ANNA NETO, J.L. 1994. Dinâmica atmosférica e o caráter transicional do clima na zona costeira paulista. Rev. Depto. Geogr.-USP, 8: 34-49.

SHORT, A.D. 1979. Three dimensional beach-stage model. Jour. Geol., 87:553-571.

SOARES, R.M. \& ALFREDINI, P. 1996. Estudo dos processos litorâneos na costa brasileira - 1 - Praias de Fora das ilhas do Cardoso e Comprida (SP). Bol. Téc. Esc. Politécnica da USP (D.E.H.S.). 15p.

SONDOTÉCNICA. 1977. Comportamento Hidráulico e Sedimentológico do Estuário Santista. Relatório Final. 426p. + Anexos.

SOUZA, C.R.G. 1990. Considerações sobre os Processos Sedimentares Quaternários e Atuais na Região de Caraguatatuba, Litoral Norte do Estado de São Paulo. Dissertação de Mestrado, Instituto Oceanográfico-USP.

SOUZA, C.R.G. 1994. Sedimentology applied for determination of net shore-drift direction. In: Inter. Sedimentological Congr., $14^{\text {th }}$, Recife. Abstracts, p. J38-J40.

SOUZA, C.R.G. 1995a. Sedimentology applied to coastal management of the state of São Paulo, Brazil. In: Coastal Change - Bordomer 95, Bordeaux. Actes / Proceedings, Tome I, p. $217-228$.

SOUZA, C.R.G. 1995b. A planície de maré de Caraguatatuba: exemplo único no litoral paulista. In: Congr. Assoc. Bras. Estudos do Quaternário (ABEQUA), V, Niterói. Anais, p. 135-141.

SOUZA, C.R.G. 1996. Cartografia de risco a inundação no litoral paulista: o exemplo do municipio de São Sebastião. In: Simp. Bras. Cartografia Geotécnica, $2^{\circ}$, São Carlos. Anais, p. 139-148.

SOUZA, C.R.G. \& FURTADO, V.V., 1987. Exemplo de desenvolvimento de planície de maré na região da Enseada de Caraguatatuba. In: Simpósio de Ecossistemas da Costa Sul e Sudeste Brasileira, $1^{\circ}$, Cananéia. Public. ACIESP, 54-II (2), 337-352. 
SOUZA, C.R.G. \& SUGUIO, K. 1995. Processos erosivos no litoral de São Paulo: um risco crescente. In: Simp. Nac. Controle de Erosão, $5^{\circ}$, Bauru, ABGE/UNESP. Anais e Boletim de Campo, p. 471-474.

SOUZA, C.R.G. \& SUGUIO, K. 1996a. Coastal erosion and beach morphodynamics along the state of São Paulo (SE Brazil). An. Acad. Bras. Ciênc., 68 (3): 405-424.

SOUZA, C.R.G. \& SUGUIO, K. 1996b. Processos erosivos no litoral paulista. In: Cong. Bras. Geol. XXXIX, Salvador. Anais, v. 4, p. 398-401.

STAPOR Jr., F.W. \& MAY, J.P. 1983. The cellular nature of littoral drift along the northeast Florida coast. Mar. Geol., 51: 217-237.

SUGUIO, K. 1973. Introdução à Sedimentologia. Ed. Edgard Blucher/EDUSP. 317p.

SUGUIO, K. 1992. Dicionário de Geologia Marinha. T. A. Queiroz (ed.). 171p.

SUGUIO, K. \& MARTIN, L. 1978. Quaternary marine formations of the state of São Paulo and southern Rio de Janeiro. In: Inter. Symp. Coastal Evolution Quaternary, São Paulo. IGCP/IGUSP/SBG. Spec. Public., 1, 55 p.

SUGUIO, K. \& MARTIN, L. 1994. Geologia do Quaternário. In: F.F. Falconi \& A. Negro Jr. (eds.). Solos do Litoral de São Paulo. p. 69-97.

SUGUIO, K. \& PETRI, S. 1973. Stratigraphy of the Iguape-Cananeia lagoonal region sedimentary deposits, São Paulo, Brazil. Part I: Field observations and grain size analysis. Bol. IG-USP, 4:1-20.

TAGGART, B. E. \& SCHWARTZ, M.L. 1988. Net shore-drift direction determination: a systematic approach. Jour. Shoreline Manag., 3(4): 285-309.

TANNER, W.F. 1995. Environmental Clastic Granulometry. Department of Environmental Protection, Florida Geological Survey. Special Public. $n^{\circ} 40,142 p$.

TESSLER, M. G. 1988. Dinâmica Sedimentar Quaternária no Litoral Sul Paulista. Tese de Doutorado, Inst. Geociências-USP. 2 volumes.

TOLDO Jr., E.E.; ALMEIDA, L.E.S.B.; DEILLENBURG, S.R.; TABAJARA, L.L.; FERREIRA, E.R. \& BORGHETTI, C. 1993. Parâmetros Morfodinâmicos e deriva litorânea na Praia Tramandai- RS. Geosul (Porto Alegre), n 15, ano VIII, p. 75-88.

TOMAZELLI, L.J.; VILLWOCK, J.A.; DILLENBURG, S.R.; BACHI, F.A.. \& DEHNHARDT, B.A. 1996. A erosão costeira no Rio Grande do Sul. In: Congr. Bras. Geol., XXXIX, Salvador. Anais, v. 4, p. 435-438.

VALENTINI, E. \& NEVES, C.F. 1989. The coastine of Rio de Janeiro from a engineering point of view. In: C.F. Neves (ed.). Coastlines of Brazil. ASCE. p.30-44.

VALIA, H.S. \& CAMERON, B. 1977. Skewness as paleoenvironmental indicator. Jour. Sed. Petrol., 47 (2): 784-793.

WRIGHT, L.D. \& SHORT, A.D. 1984. Morphodynamics variability of surf zone and beach. Mar. Geol., 56: 93-118.

WRIGHT, L.D.; CHAPPELL, J.; THOM, B.G.; BRADSHAW, M.P. \& COWELL, P. 1979. Morphodynamics of reflective and dissipative beach and inshore systems: Southern Australia. Mar. Geol., 32: 105-140. 